ARH-ST -156

UC -70

\title{
EVALUATION OF SCINTILLATION PROBE PROFILES \\ FROM 200 AREA CRIB MONITORING WELLS \\ VOLUME II
}

\author{
K. R. Fecht \\ G. V. Last \\ K. R. Price \\ Research Department \\ Research and Engineering Division
}

June 1977

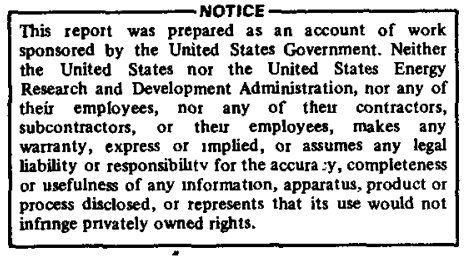

Atlantic Richfield Hanford Company

Richland, Washington 99352 


\section{DISCLAIMER}

This report was prepared as an account of work sponsored by an agency of the United States Government. Neither the United States Government nor any agency Thereof, nor any of their employees, makes any warranty, express or implied, or assumes any legal liability or responsibility for the accuracy, completeness, or usefulness of any information, apparatus, product, or process disclosed, or represents that its use would not infringe privately owned rights. Reference herein to any specific commercial product, process, or service by trade name, trademark, manufacturer, or otherwise does not necessarily constitute or imply its endorsement, recommendation, or favoring by the United States Government or any agency thereof. The views and opinions of authors expressed herein do not necessarily state or reflect those of the United States Government or any agency thereof. 


\section{DISCLAIMER}

Portions of this document may be illegible in electronic image products. Images are produced from the best available original document. 
ARH-ST-156

APPENDIX A

\section{EVALUATION OF SCINTILLATION PROBE PROFILES \\ FROM 200 AREAS CRIB MONITORING WELLS \\ 200 EAST AREA}

Appendix A presents information on 200 East Area crib monitoring wells and the crib facilities monitored. Figure A-l is a plan view of 200 East Area showing the location of crib facilities and depth to groundwater. The remainder of the appendix contains descriptive information and computer-generated scintillation probe profiles for cribs in the 200 East Area. Facilities are listed alphabetically and chronologically, i.e., 216-A-1, 216-A-2, ... 216-B-1, 216-B-2, ... etc. Each facility is described in detail as to the specific location, size, dates of operation and waste received.

Information provided in this appendix has been collected from the sources listed below.

1. J. D. Anderson, Input and Decayed Valves of Radioactive Liquid Wastes Discharged to the Ground in the 200 Areas Through 2975, ARH-CD-745, Atlantic Richfield Hanford Company, Richland, Washington, Ju1y 8, 1976.

2. L. L. Lundgren, 200 East and North Areas Radioactive Waste Disposal Facilities, ARH-1562, Atlantic Richfield Hanford Company, Richland, Washington, January 1, 1970.

3. V. L. McGhan, D. A. Myers and D. W. Damschen, Hanford WeZZs, BNWL-1981, Battelle Pacific Northwest Laboratories, Richland, Washington, March 1976.

4. J. E. Mirabella, Radioactive Liquid Wastes Discharged to Ground in the 200 Areas During the First Half 1976, ARH-CD-743 2Q, Atlantic Richfield Hanford Company, Richland, Washington, November 1976.

5. J. R. Raymond and V. L. McGhan, Scintizlation Probe Results - 200 Area Waste Disposal Site Monitoring Wells, HW-84577, General Electric Company, December 17, 1964. 
6. D. D. Tillson and V. L. McGhan, Changes in Scintizzation Probe Findings -- 1964 to 1968, 200 Area Waste Disposal Site Monitoring WeZZs, BNWL-CC-2255, Battelle Pacific Northwest Laboratories, Richland, Washington, August 29, 1969. 


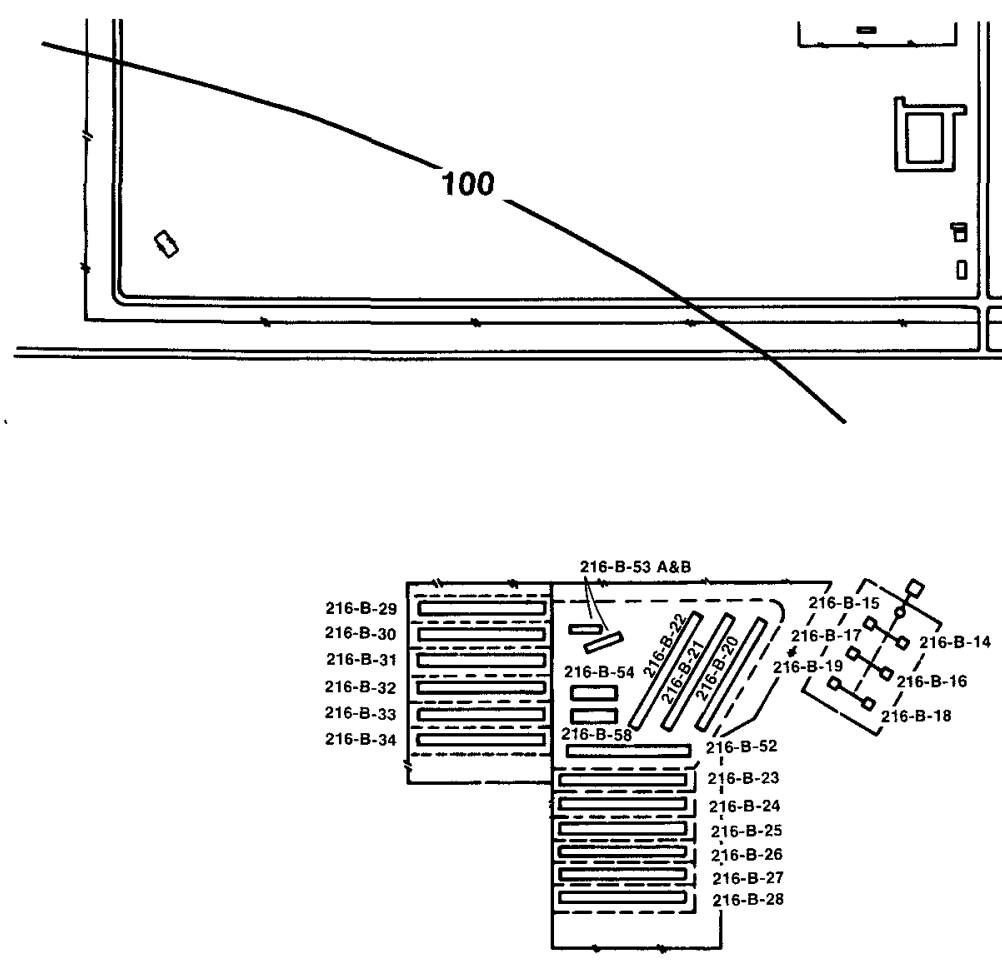

FIGURE A-1 200 EAST CRIB FACILITIES AND DEPTH IN METERS TO GROUNDWATER 


\section{6-A-1 Specific Retention Crib}

Description of Waste: Deactivated uranium waste from cold startup in 202-A.

Service Dates: 1955

Waste Volume: $9.84 \times 10^{4}$ liters

Waste Inventory:

\begin{tabular}{ccc} 
& Total & Decayed Thru June 1976 \\
\cline { 2 - 3 } $\mathrm{Pu}, \mathrm{g}$ & $<1.00 \times 10^{-1}$ & $<1.00 \times 10^{-1}$ \\
${ }^{\text {Beta, } \mathrm{Ci}}$ & $1.00 \times 10^{0}$ & $2.44 \times 10^{-1}$ \\
${ }^{90} \mathrm{Sr}, \mathrm{Ci}$ & $<1.00 \times 10^{-1}$ & $<5.97 \times 10^{-2}$ \\
${ }^{106} \mathrm{Ru}, \mathrm{Ci}$ & $<1.00 \times 10^{-1}$ & $<5.13 \times 10^{-8}$ \\
${ }^{137} \mathrm{Cs}, \mathrm{Ci}$ & $<1.00 \times 10^{-1}$ & $<6.17 \times 10^{-2}$ \\
${ }^{60} \mathrm{Co}, \mathrm{Ci}$ & $<1.00 \times 10^{-1}$ & $<6.28 \times 10^{-3}$ \\
$\mathrm{U}, \mathrm{kg}$ & $1.54 \times 10^{2}$ & $1.54 \times 10^{2}$
\end{tabular}

Evaluation of Scintillation Probe Profiles:

Well E25-2 monitors the 216-A-1 specific retention crib (figures $\mathrm{A}-1$ and $\mathrm{A}-2$ ). Radioactive contaminants are detected 3.4 meters below the distributor pipe increasing to maximum radiation intensity 9.1 meters below the distributor pipe (figure A-3). The radiation profile from scintillation logging in 1963, 8 years after disposal to the crib was terminated, shows the radionuclides have been retained high in the sediment column beneath the distributor pipe.

Changes in the radiation profile that have occurred between 1963 and 1976 are attributed to a reduction in the radiation intensity due to radionuclide decay. On the basis of the single well monitoring structure, Well E25-2, no measurable migration of radionuclides disposed to the ground at the 216-A-1 crib has been detected. These data indicate that breakthrough to the groundwater has not occurred at this site. 

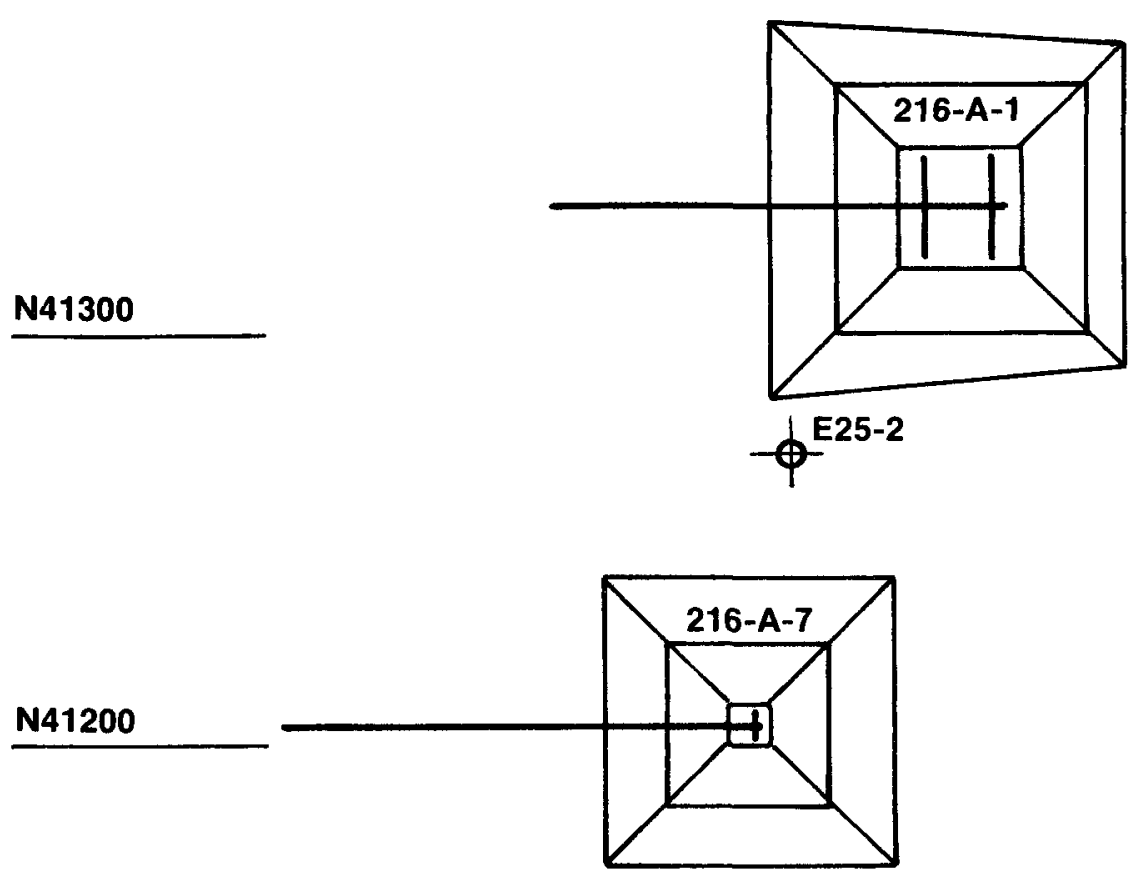

N41100
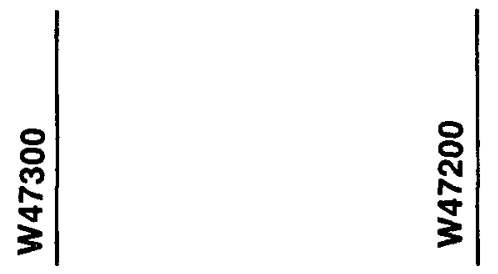

号

FIGURE A-2

216-A-1 AND 216-A-7 CRIB PLOT PLANS 


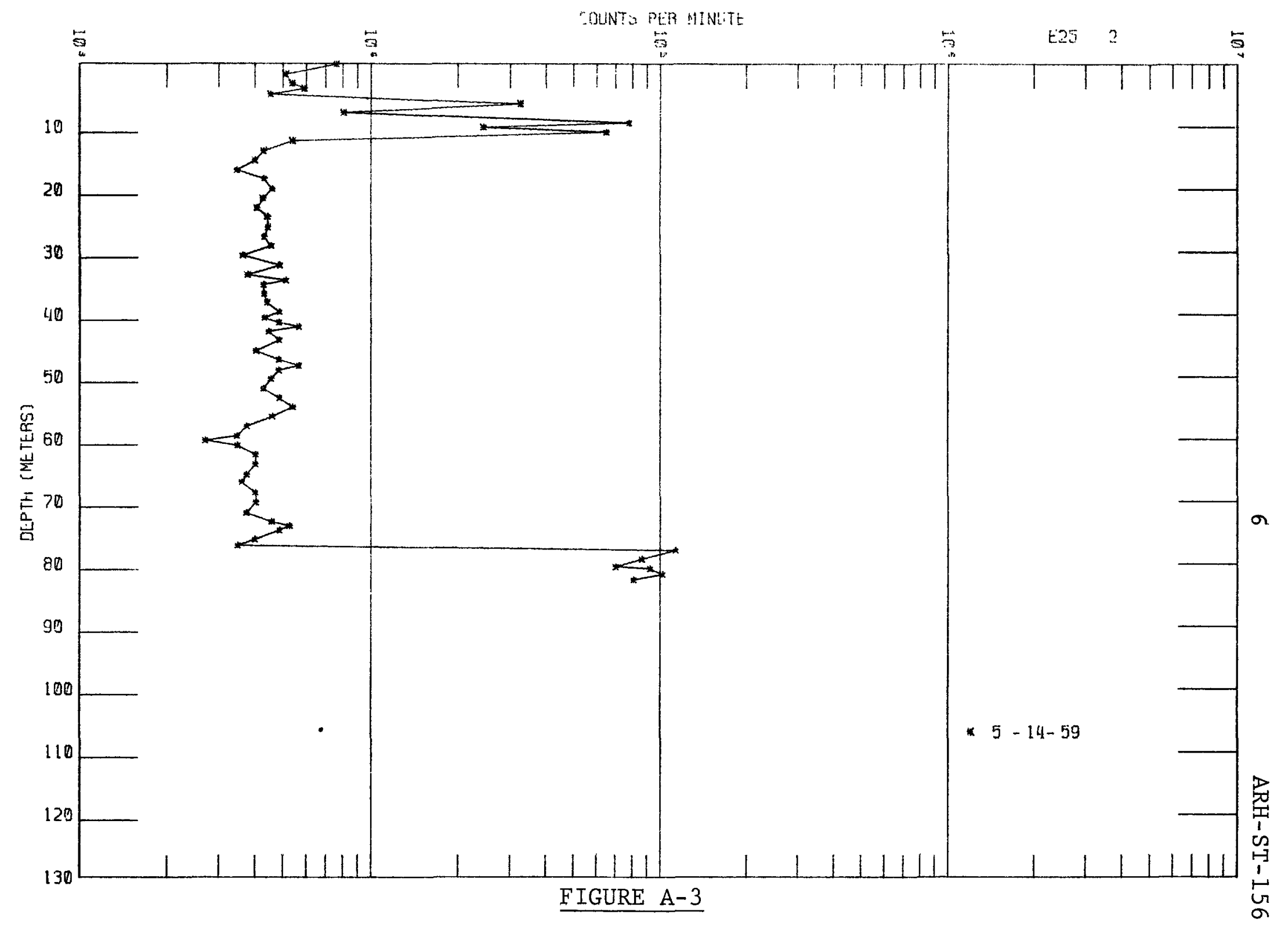

WELL E25-2 SCINTILLATION PROBE PROFILES 


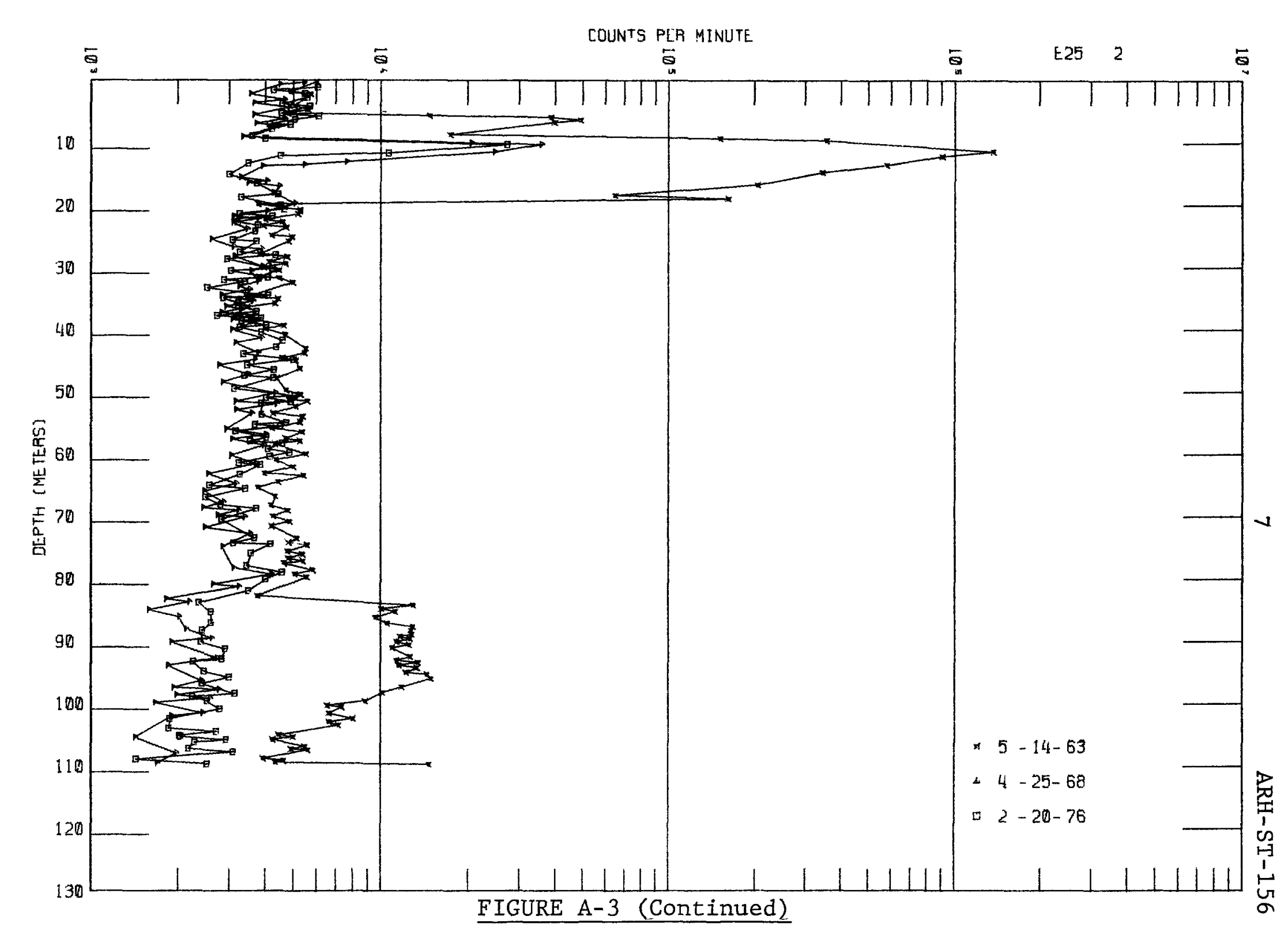

WELL E25-2 SCINTILLATION PROBE PROFILES 


\section{6-A-2 Specific Retention Crib}

Description of Waste: Low salt, neutral-basic organic from 202-A.

Service Dates: 1956 to 1960

Waste Volume: $2.30 \times 10^{5}$ liters

Waste Inventory:

\begin{tabular}{ccc} 
& Total & Decayed Thru June 1976 \\
\cline { 2 - 3 } $\mathrm{Pu}, \mathrm{g}$ & $1.30 \times 10^{2}$ & $1.30 \times 10^{2}$ \\
$\mathrm{Beta}^{\mathrm{B}} \mathrm{Ci}$ & $5.90 \times 10^{2}$ & $6.93 \times 10^{1}$ \\
${ }^{90} \mathrm{Sr}, \mathrm{Ci}$ & $2.00 \times 10^{0}$ & $1.31 \times 10^{1}$ \\
${ }^{106} \mathrm{Ru}, \mathrm{Ci}$ & $1.50 \times 10^{2}$ & $1.46 \times 10^{-3}$ \\
${ }^{137} \mathrm{Cs}, \mathrm{Ci}$ & $3.00 \times 10^{0}$ & $2.01 \times 10^{0}$ \\
${ }^{60} \mathrm{Co}, \mathrm{Ci}$ & $1.00 \times 10^{0}$ & $1.04 \times 10^{-1}$ \\
$\mathrm{U}, \mathrm{Kg}$ & $7.81 \times 10^{1}$ & $7.81 \times 10^{1}$
\end{tabular}

\section{Evaluation of Scintillation Probe Profiles:}

Well E24-53 is a shallow monitoring structure that partially penetrates the zone of contamination from radioactive effluent disposed to the ground from the 216-A-2 specific retention crib (figures $A-1$ and A-4). Radioactive contaminants are detected 2.1 meters below the distributor pipe increasing to maximum radiation intensity 4.6 meters below the distributor pipe (figure A-5). On the basis of the single shallow well monitoring structure, E24-53 no measurable migration of radionuclides in the logged portion of the zone of contamination can be detected between 1963 and 1976. The slow rate of decay at the 10 meter depth is probably due to the retention of long-lived radionuclides high in the sediment column immediately below the distributor pipe. The waste volume and waste inventory indicate breakthrough to the groundwater has not occurred at this site. 

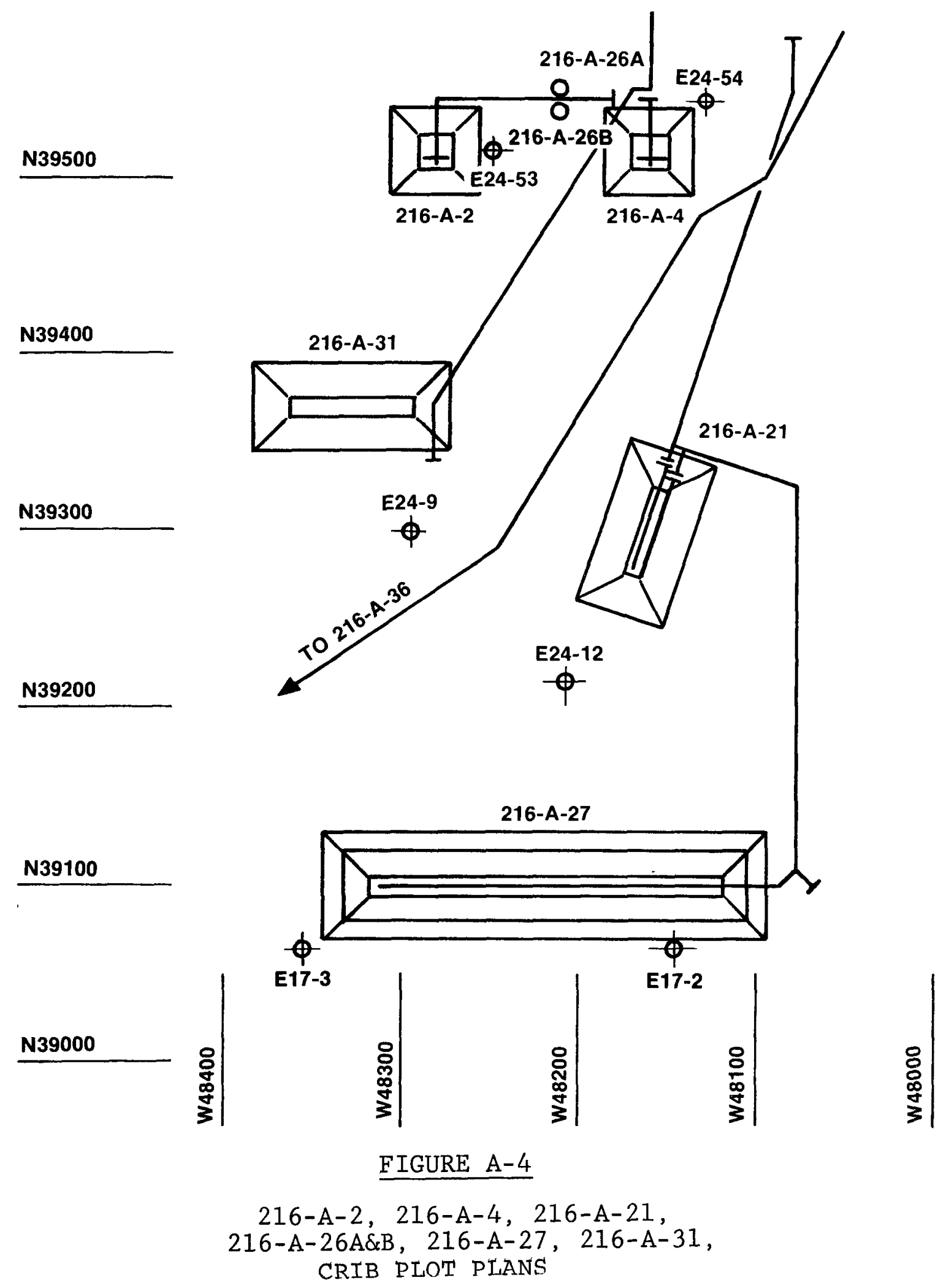

N39200

N39300
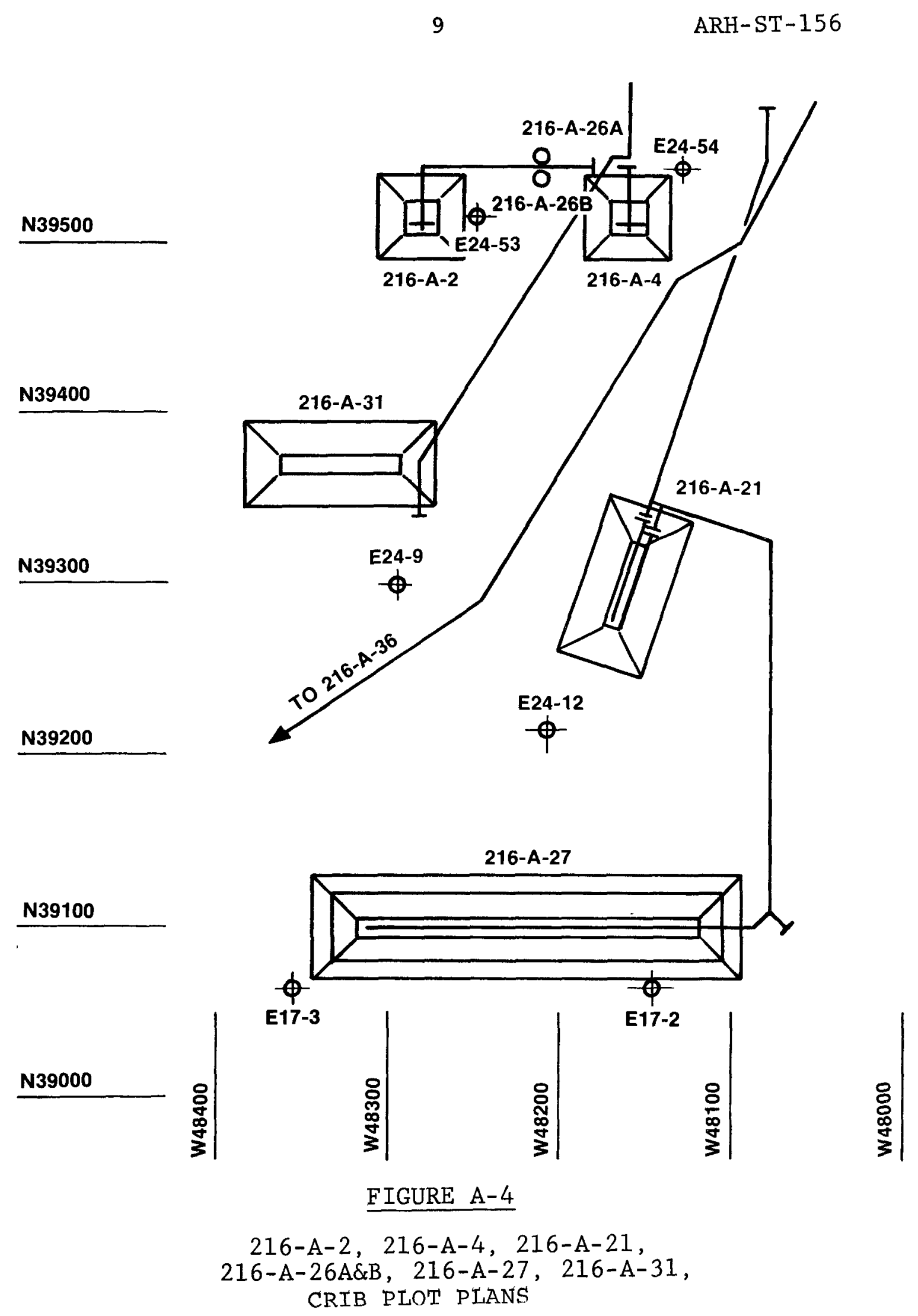


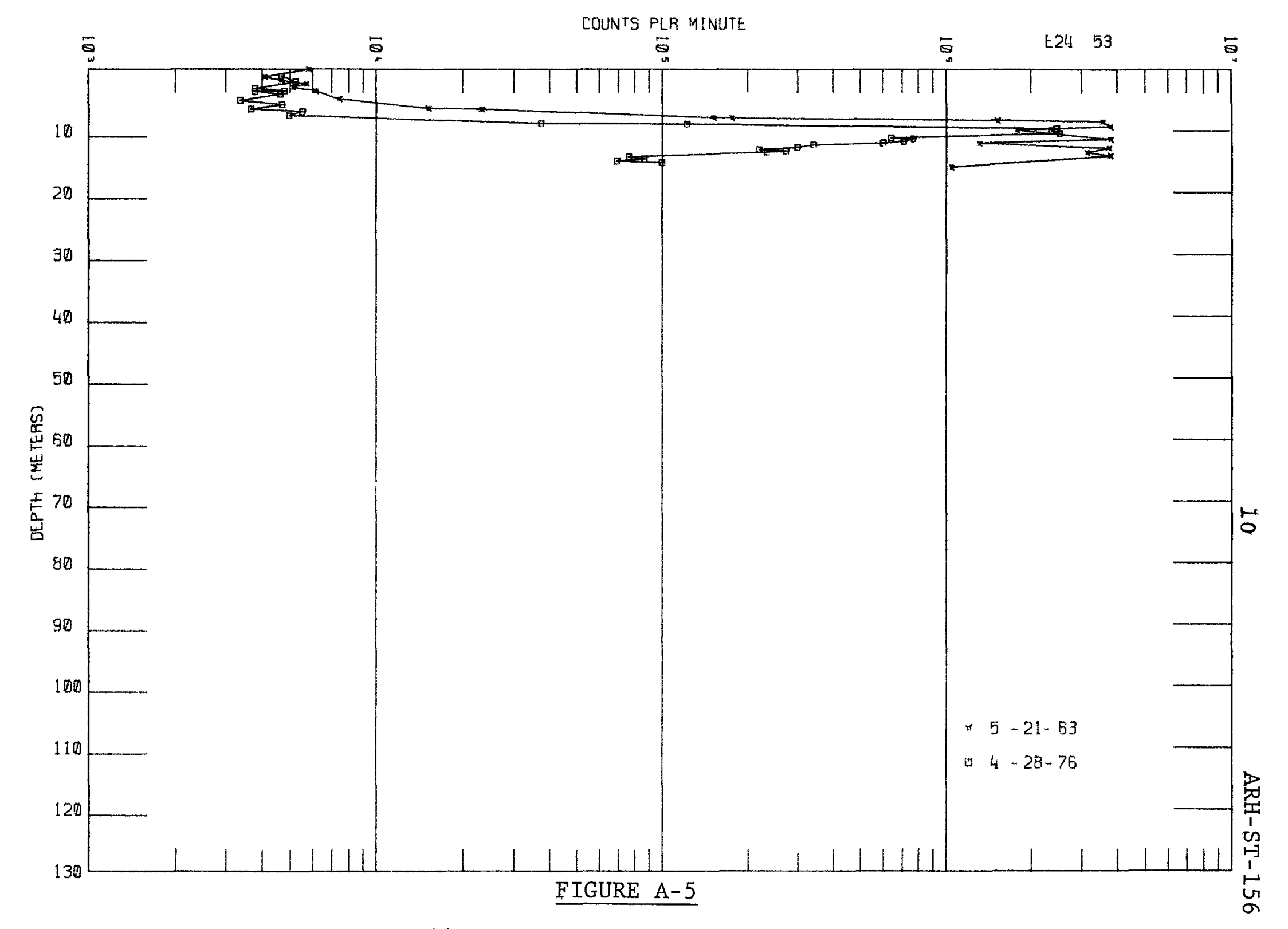

WELL E24-53 SCINTILLATION PROBE PROFILES 


\section{6-A-4 Specific Retention Crib}

Description of Waste: Laboratory cell drainage from Purex Plant and 291-A-1 stack drainage.

Service Dates: 1955 to 1958

Waste Volume: $6.21 \times 10^{6}$ iiters

Waste Inventory:

$\begin{array}{rcc} & \text { Total } & \text { Decayed Thru June 1976 } \\ \mathrm{Pu}, \mathrm{g} & 1.40 \times 10^{2} & 1.40 \times 10^{2} \\ { }^{\mathrm{Beta}}, \mathrm{Ci} & 8.64 \times 10^{2} & 3.10 \times 10^{7} \\ { }^{90} \mathrm{Sr}, \mathrm{Ci} & 1.00 \times 10^{7} & 6.23 \times 10^{0} \\ { }^{106} \mathrm{Ru}, \mathrm{Ci} & 4.00 \times 10^{2} & 8.16 \times 10^{-3} \\ { }^{137} \mathrm{Cs}, \mathrm{Ci} & 1.50 \times 10^{1} & 9.63 \times 10^{0} \\ { }^{60} \mathrm{Co}, \mathrm{Ci} & 1.00 \times 10^{0} & 7.91 \times 10^{-2} \\ \text { U, kg } & 3.99 \times 10^{2} & 3.99 \times 10^{2}\end{array}$

Scintillation Probe Logging Results:

We17 E24-54 is a shallow monitoring structure that partially penetrates the zone of contamination from radioactive effluent disposed to the ground via the 216-A-4 specific retention crib (figures $A-1$ and $A-4$ ). Radioactive contaminants are detected at the ground surface (figure A-6). The major zone of contamination is 1.5 meter below the distributor pipe. The high radiation intensity in the lower portion of the we11, 18 years after disposal to the crib was terminated, is due to the retention of long-1ived radionuclides near the point of discharge. We11 E24-54 was filled with sand to within 1.7 meters of the ground surface. The waste volume and waste inventory indicate breakthrough to the groundwater has not occurred at this site. 


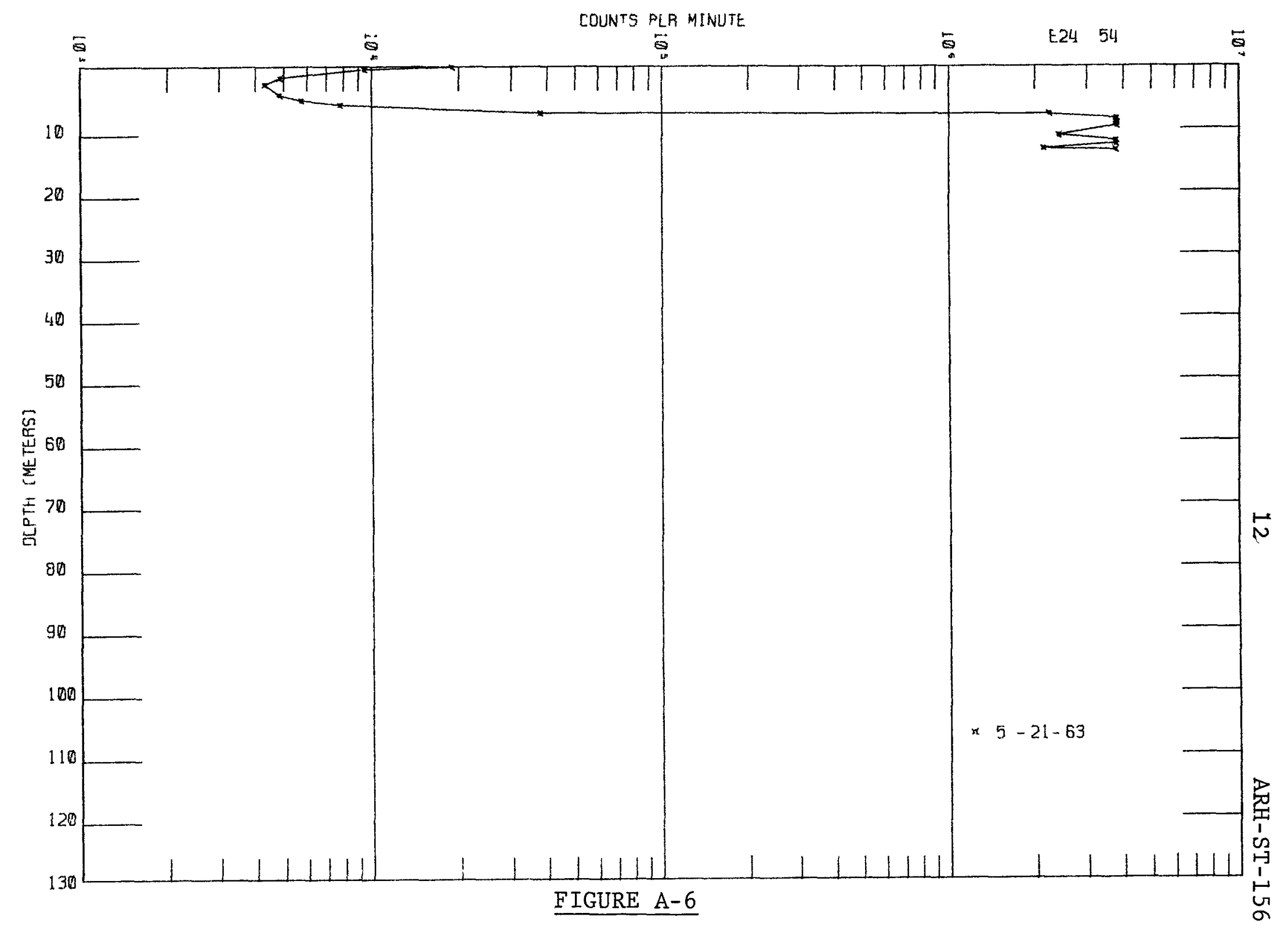

WELL E24-54 SCINTILLATION PROBE PROFILE 


\section{6-A-5 Crib}

Description of Waste: Process condensate from 202-A

Service Dates: 1955 to 1961 and 1966

Waste Volume: $1.63 \times 10^{9}$ 1iters

Waste Inventory:

\begin{tabular}{|c|c|c|}
\hline & Total & Decayed Thru June 1976 \\
\hline $\mathrm{Pu}, \mathrm{g}$ & $6.50 \times 10^{7}$ & $6.50 \times 10^{1}$ \\
\hline Beta, $\mathrm{C}_{\mathbf{i}}$ & $3.41 \times 10^{3}$ & $1.66 \times 10^{2}$ \\
\hline${ }^{90} \mathrm{Sr}, \mathrm{C} i$ & $9.00 \times 10^{7}$ & $5.90 \times 10^{7}$ \\
\hline${ }^{106} \mathrm{Ru}, \mathrm{Ci}$ & $1.50 \times 10^{2}$ & $2.01 \times 10^{-3}$ \\
\hline${ }^{137} \mathrm{Cs}, \mathrm{Ci}$ & $2.50 \times 10^{7}$ & $1.68 \times 10^{7}$ \\
\hline${ }^{60} \mathrm{Co}, \mathrm{Ci}$ & $1.10 \times 10^{2}$ & $1.16 \times 10^{1}$ \\
\hline $\mathrm{U}, \mathrm{Kg}$ & $2.63 \times 10^{2}$ & $2.63 \times 10^{2}$ \\
\hline
\end{tabular}

Evaluation of Scintillation Probe Profiles:

We11s E24-1, E24-56, E24-57 and E24-58 monitor the 216-A-5 process condensate crib (figures $A-1$ and $A-7$ ). Radioactive contaminants are detected 9.8 meters below the distributor pipe (figures A-8 through A-11). The maximum radiation intensity is located 11 meters below the distributor pipe with secondary peaks at 26.5 and 32.0 meters below the distributor pipe.

On the basis of the four monitoring structures adjacent to the 216-A-5 crib no measurable migration of the radionuclides disposed to the ground at this crib has been detected. The long-lived radionuclides are retained high in the sediment column beneath the distributor pipe as evidenced by the faster rate of decay of the radionuclides at the secondary peaks. These data indicate that breakthrough to the groundwater could have occurred at this site. 


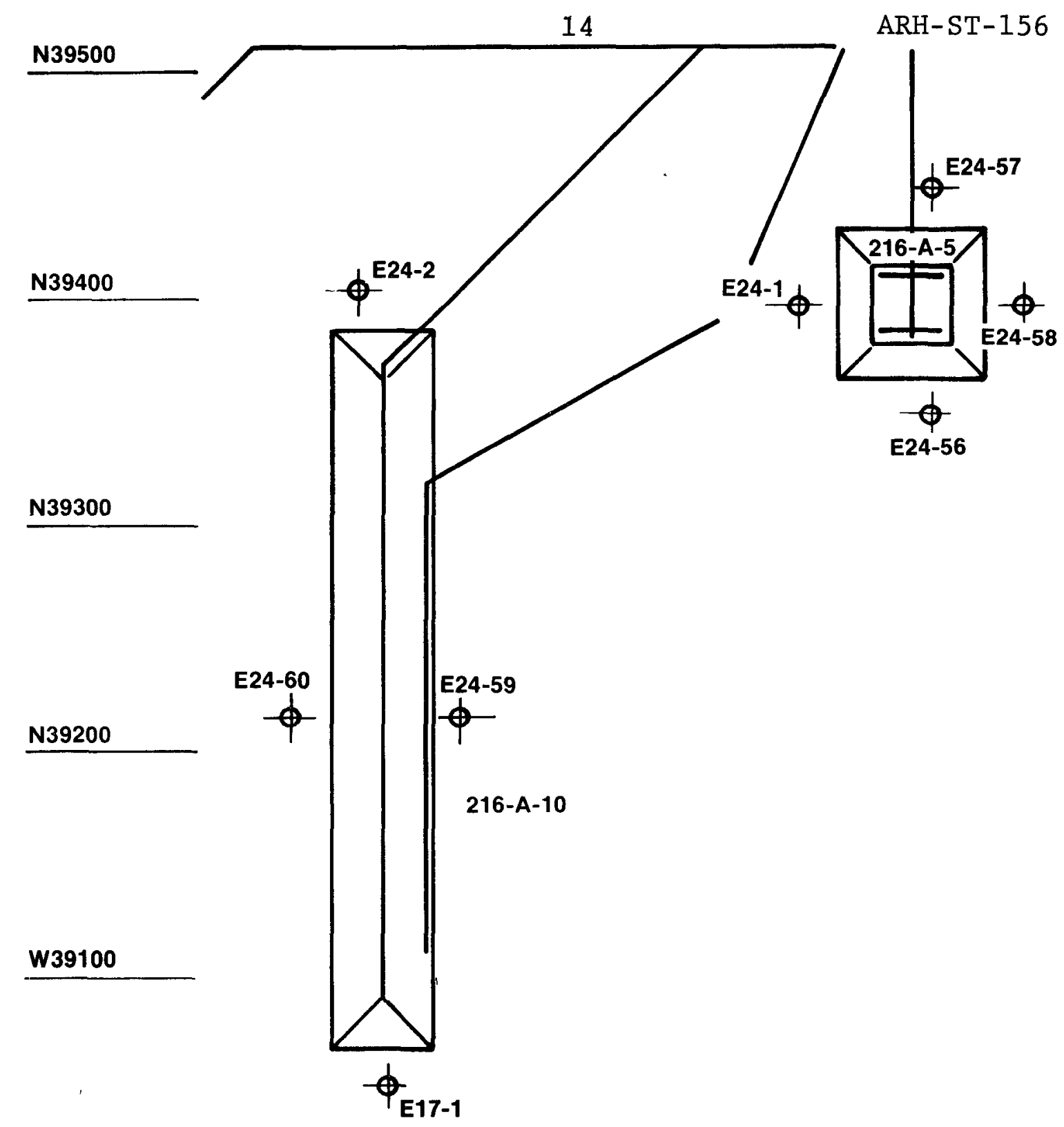

N39000

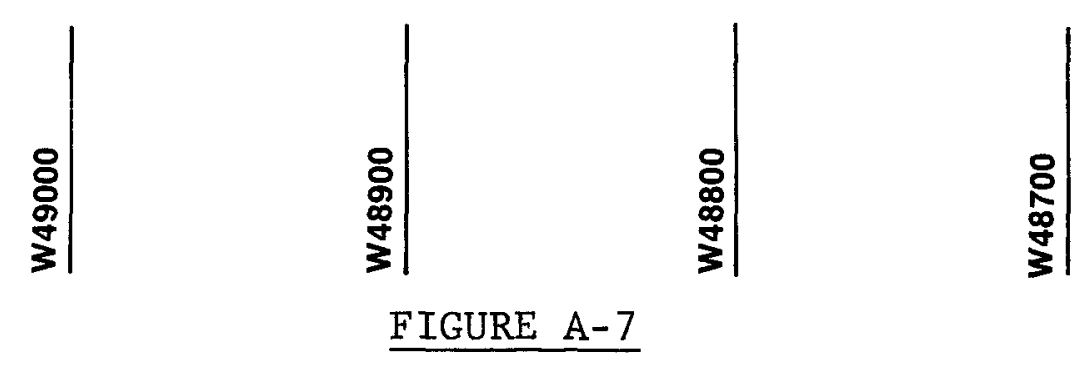

216-A-5 AND 216-A-10 CRIB PLOT PLANS 


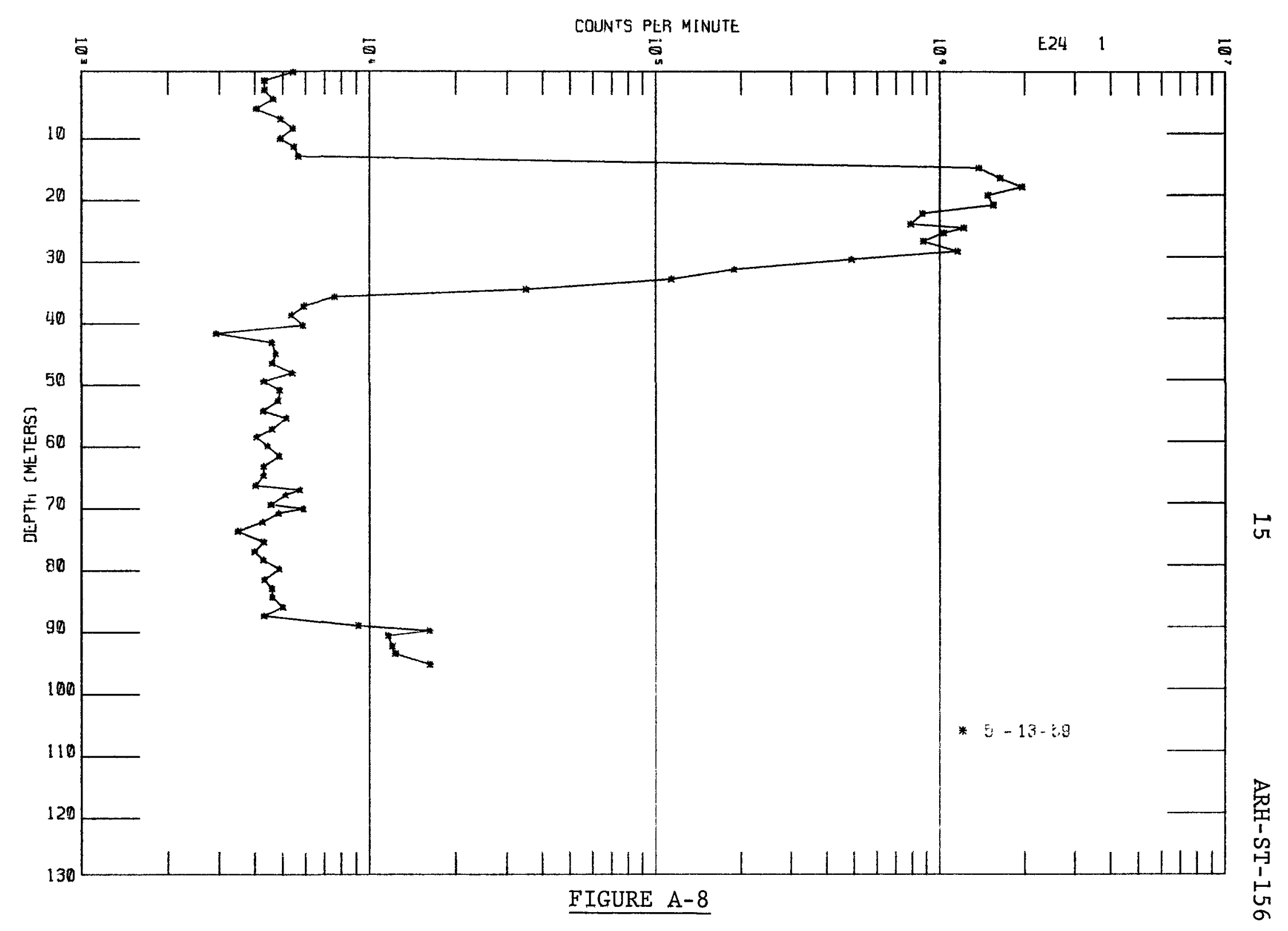

WELL E24-1 SCINTILLATION PROBE PROFILES 
0 .

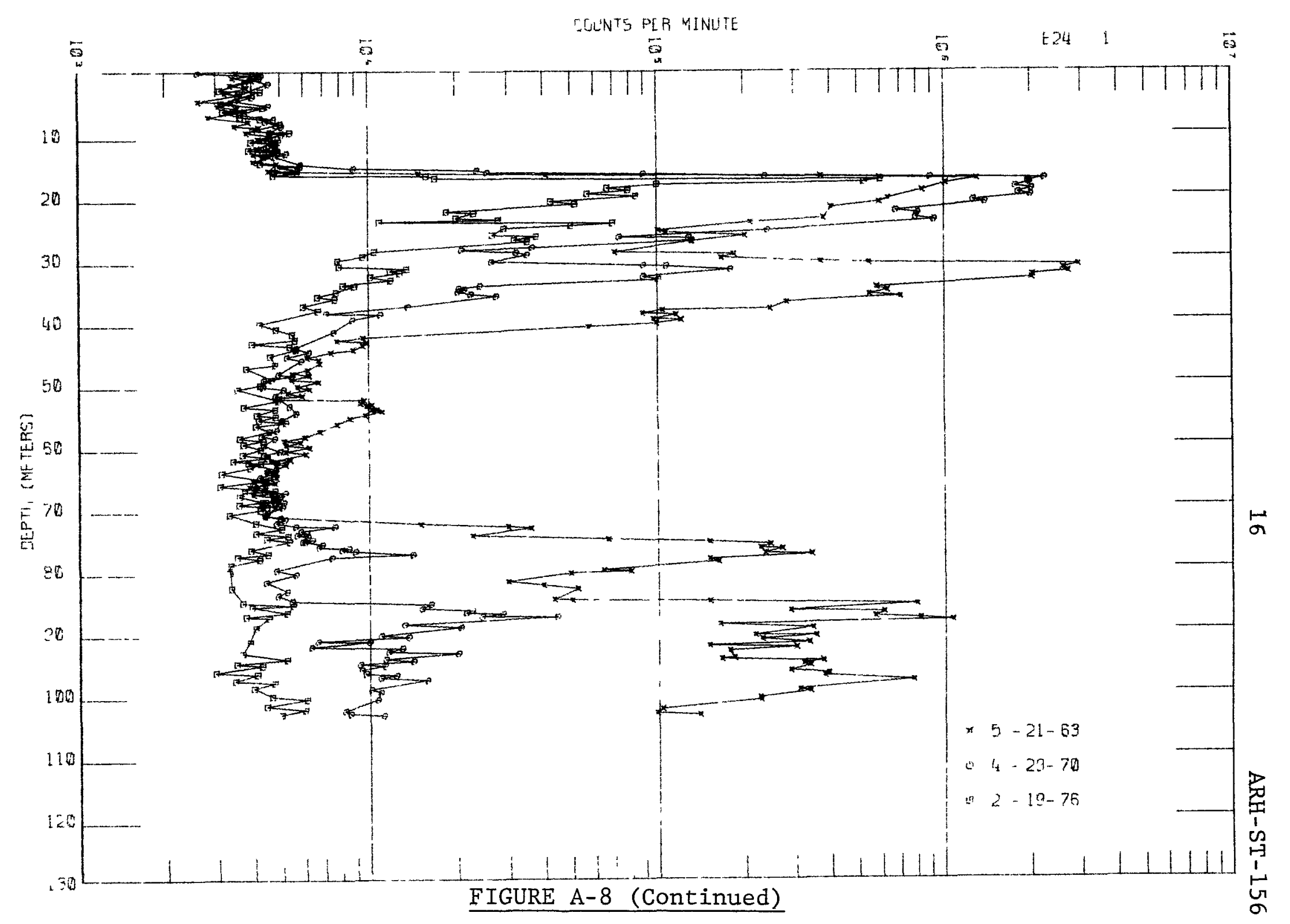

WELL E24-I SCINTILLATION PROBE PROFILES 


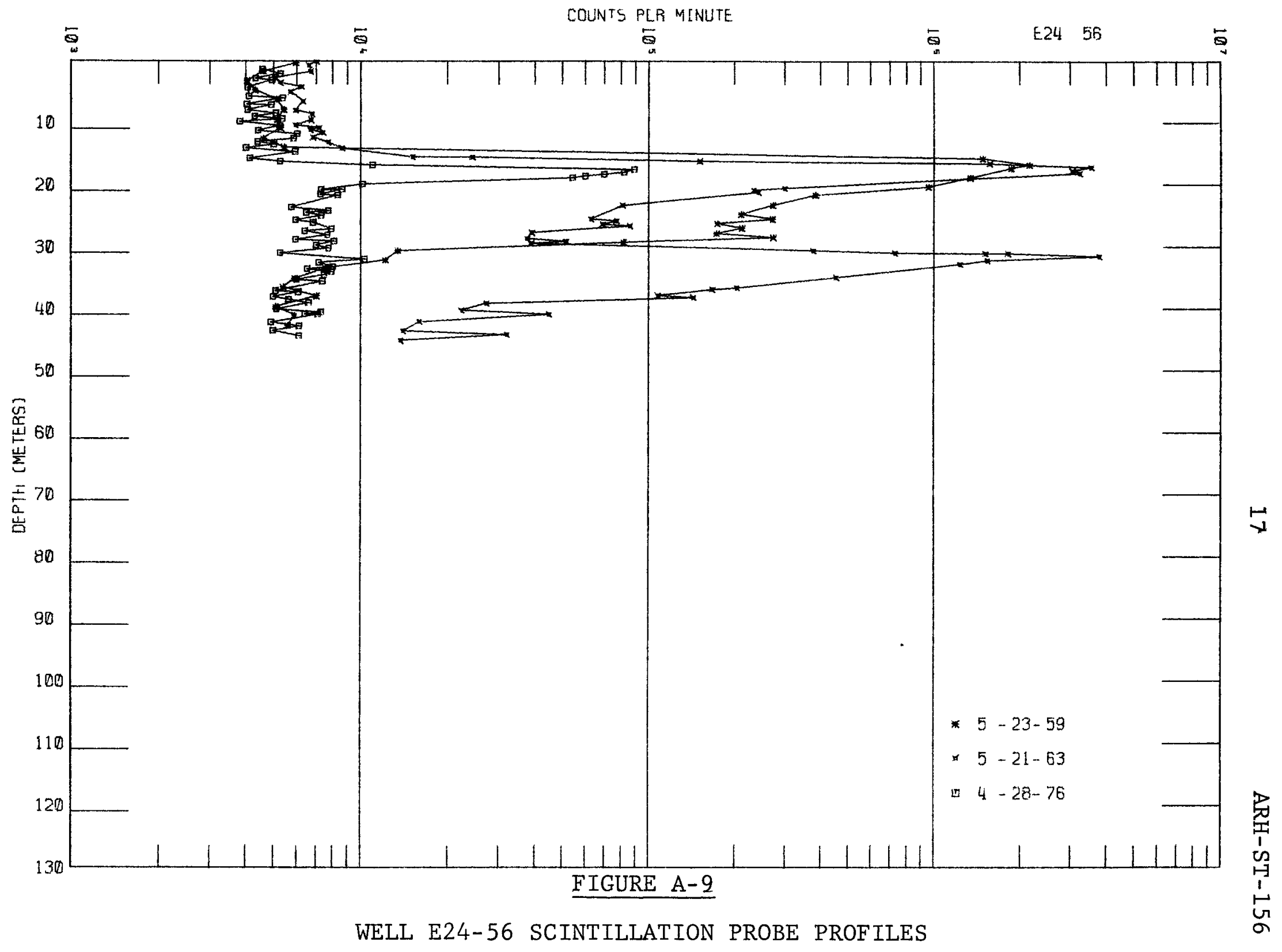




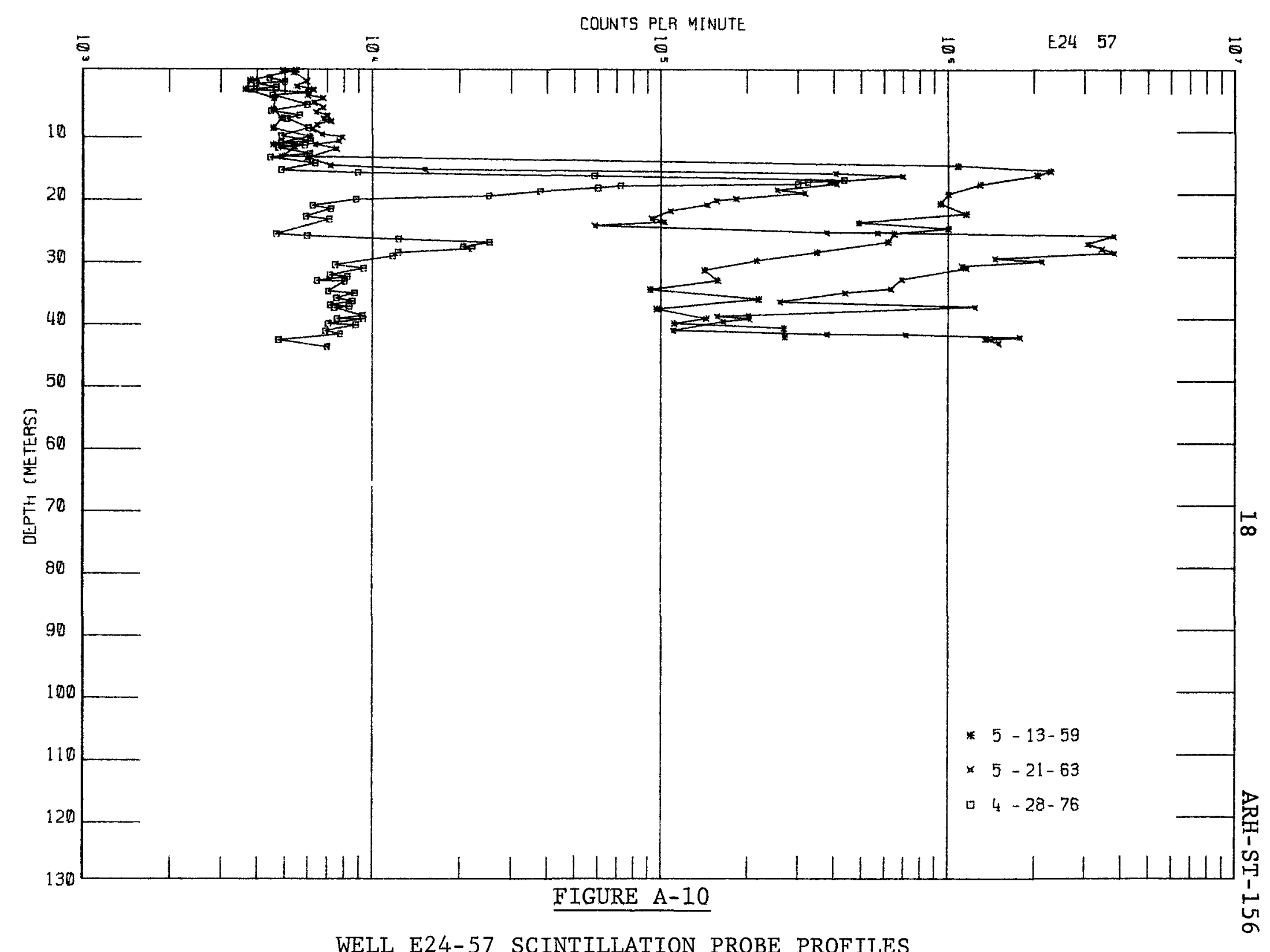




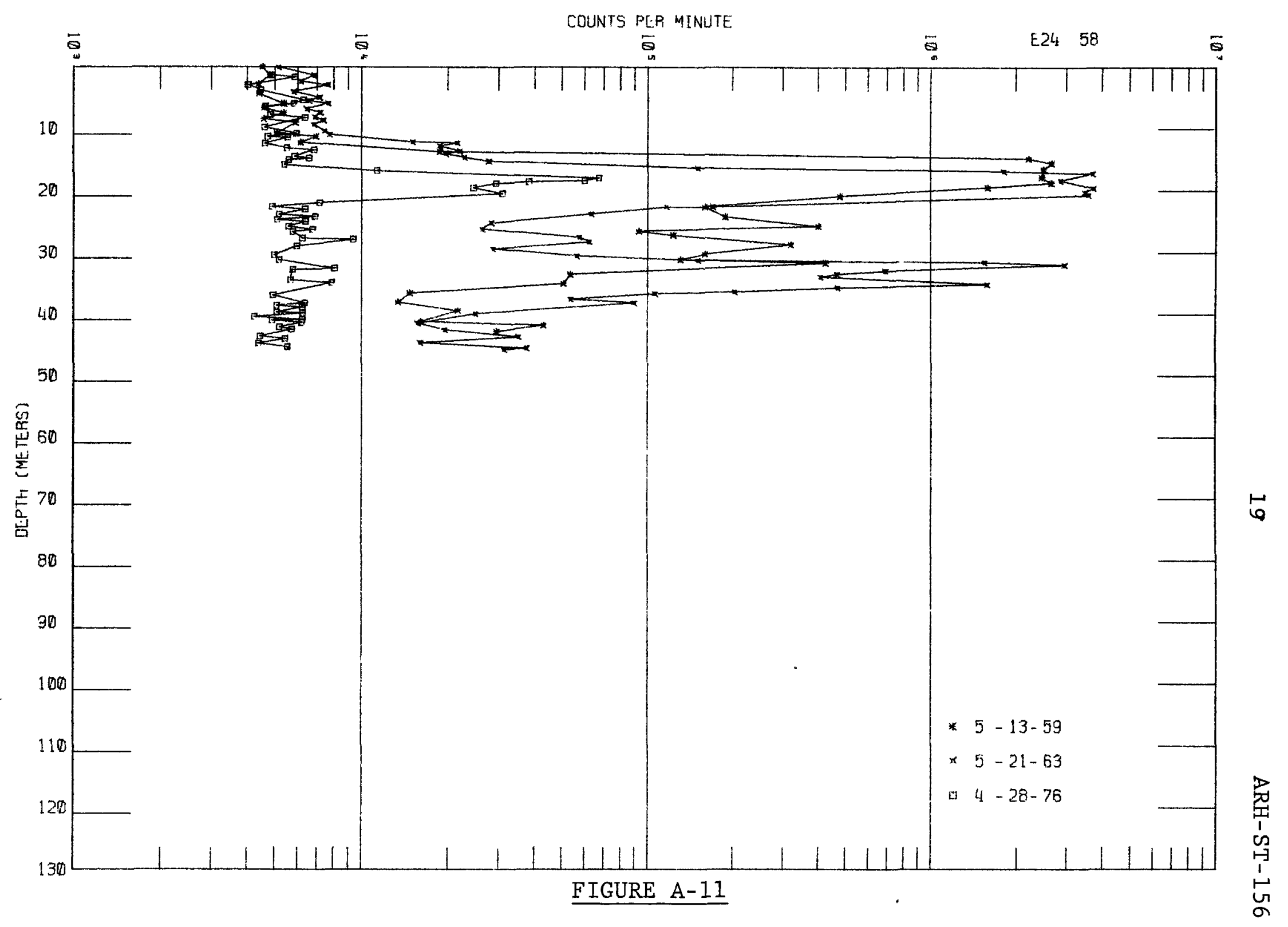

WELL E24-58 SCINTILLATION PROBE PROFILES 


\section{$216-A-6$ Crib}

Description of Waste: Steam condensate, equipment disposal tunnel floor drainage, water filled door drainage and the slug storage basin overflow waste from 202-A.

Service Dates: 1955 to 1961 and 1966 to 1970

Waste Volume: $3.4 \times 10^{9} 1$ iters

Waste Inventory:

\begin{tabular}{ccc} 
& \multicolumn{1}{c}{ Total } & Decayed Thru June 1976 \\
\cline { 2 - 3 } $\mathrm{Pu}, \mathrm{g}$ & $<3.56 \times 10^{7}$ & $<3.56 \times 10^{1}$ \\
${ }^{\mathrm{Beta}} \mathrm{Ci}$ & $7.60 \times 10^{4}$ & $5.90 \times 10^{2}$ \\
${ }^{90} \mathrm{Sr}, \mathrm{Cj}$ & $9.11 \times 10^{7}$ & $6.26 \times 10^{1}$ \\
${ }^{106} \mathrm{Ru}, \mathrm{Ci}$ & $2.23 \times 10^{2}$ & $1.02 \times 10^{-1}$ \\
${ }^{137} \mathrm{Cs}, \mathrm{Cj}$ & $2.11 \times 10^{2}$ & $1.46 \times 10^{2}$ \\
${ }^{60} \mathrm{Co}, \mathrm{Ci}$ & $1.86 \times 10^{0}$ & $6.30 \times 10^{-1}$ \\
$\mathrm{U}, \mathrm{Kg}$ & $<1.65 \times 10^{2}$ & $<1.65 \times 10^{2}$
\end{tabular}

Evaluation of Scintillation Probe Profiles;

We11s E25-3 and E25-53 monitor the 216-A-6 steam condensate crib (figures $A-1$ and $A-12$ ). Radioactive contaminants have been detected at the ground surface and decrease in radiation intensity to the distributor pipe (3.0 meters below the ground surface) (figure A-13). Radiation intensity increases 3.7 meters below the distributor pipe reaching maximum intensity 6.7 meters below the distributor pipe (figures $A-13$ and A-14). On the basis of We11 E25-3 no measurable migration of radionuclides disposed to the ground at the 216-A-6 crib has been detected from scintillation probe profiles. These data also indicate breakthrough to the groundwater has not occurred at this site. 

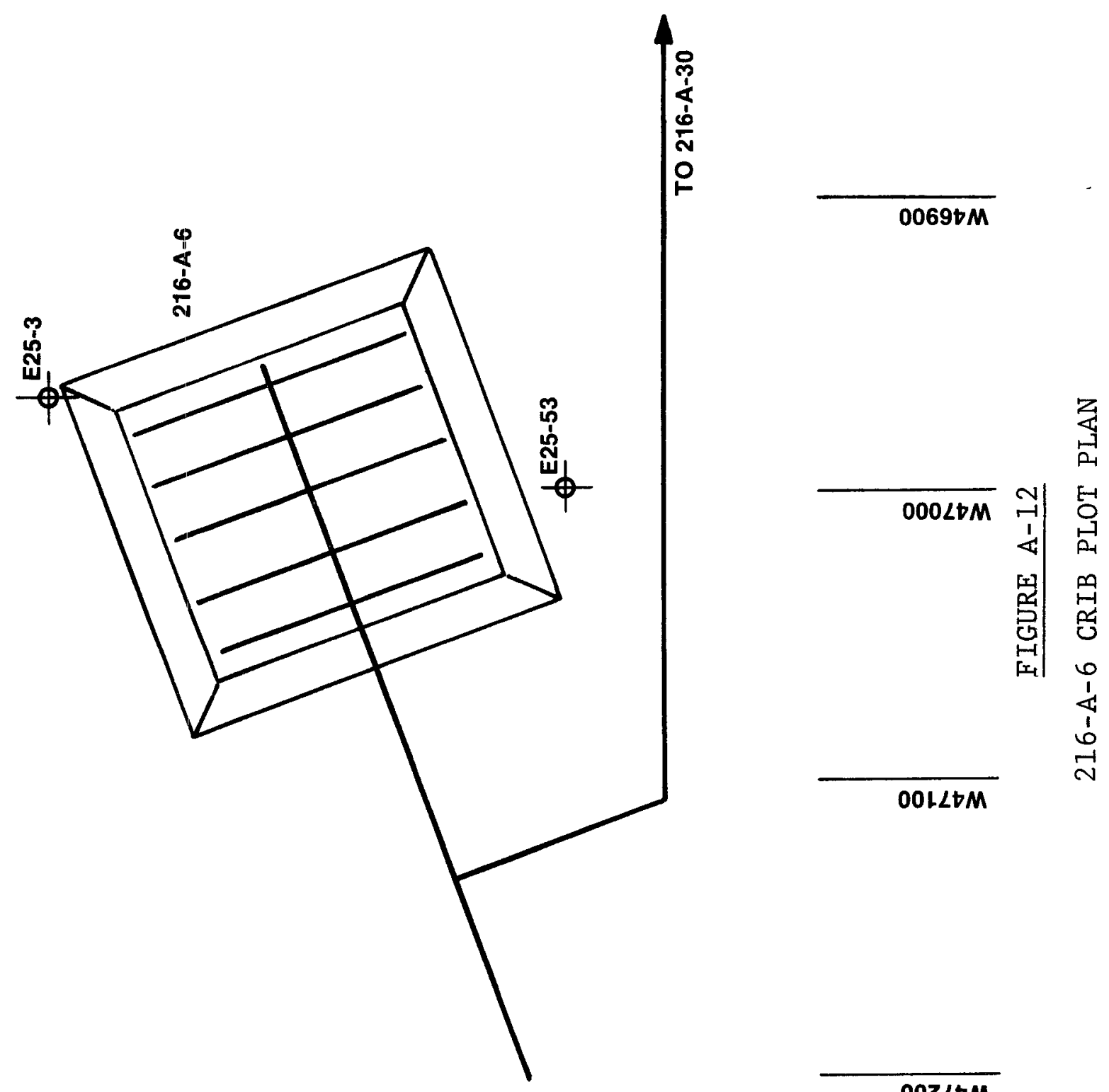

จ
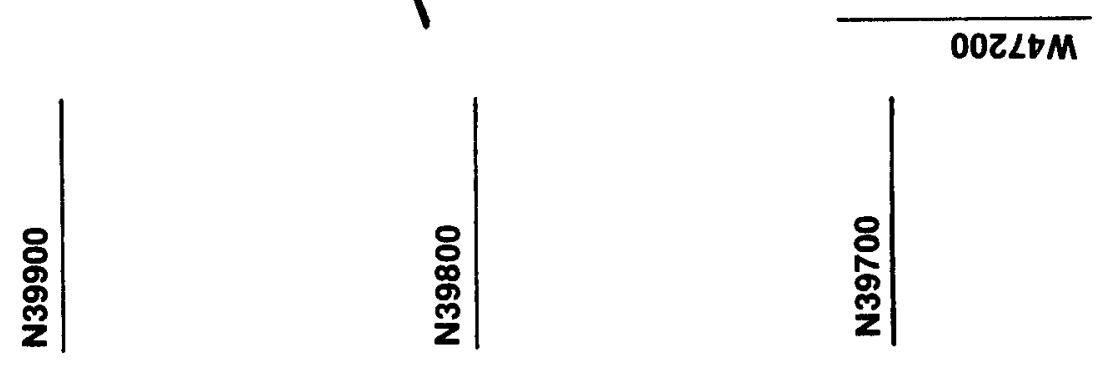
$0 *$

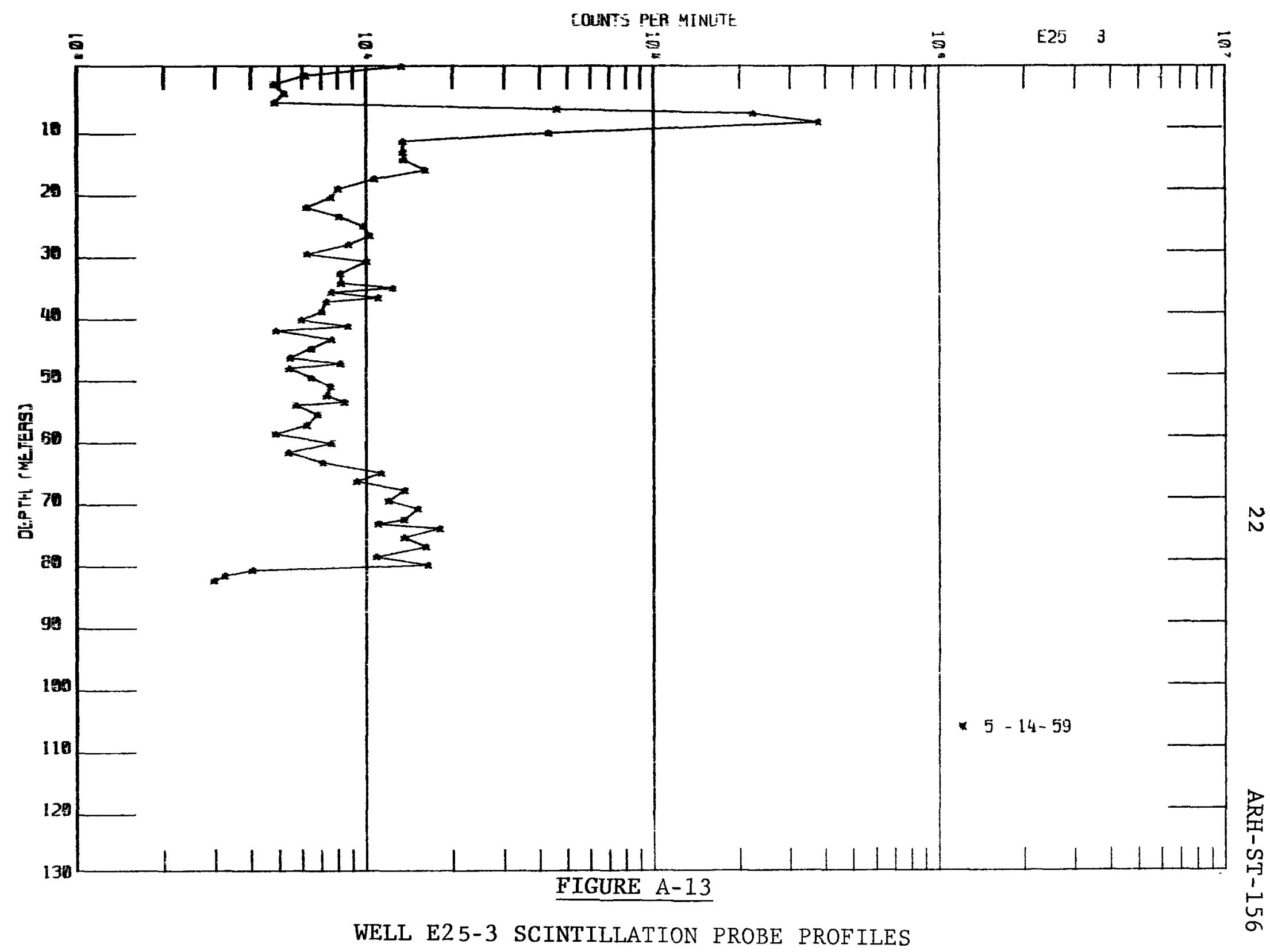




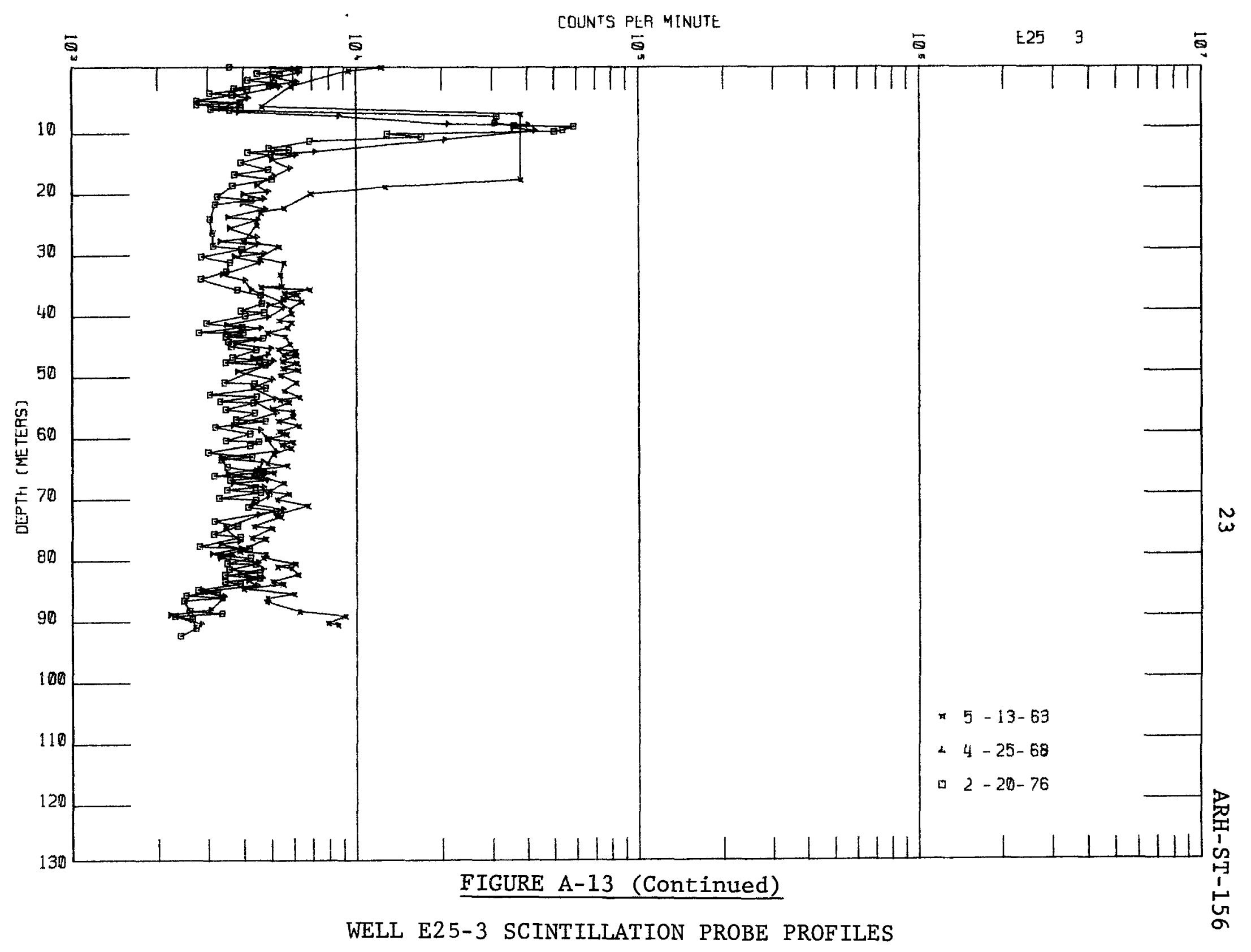




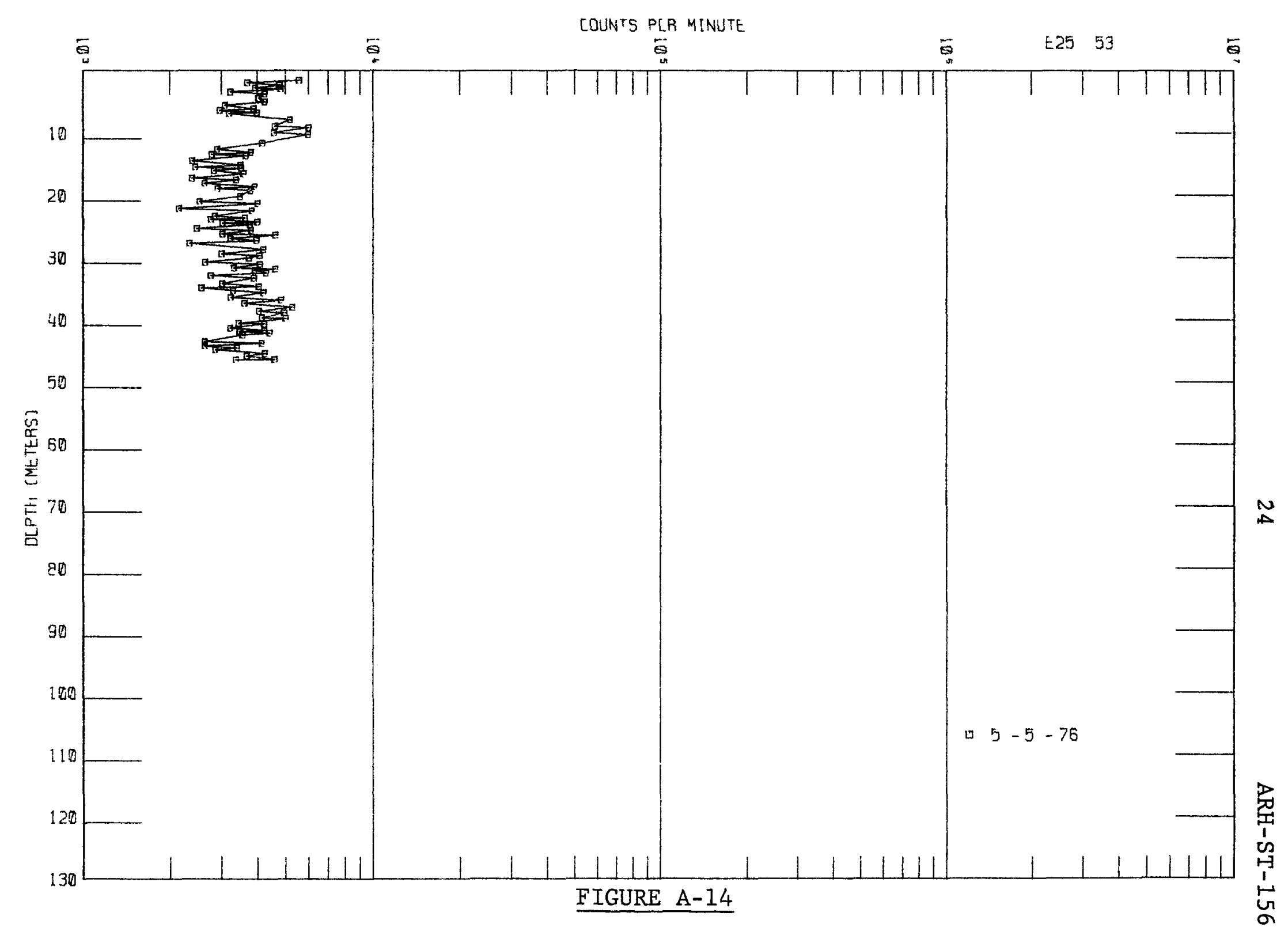

WELL E25-53 SCINTILLATION PROBE PROFILES 


\section{6-A-8 Crib}

Description of Waste: Condensate and cooling water from waste storage tanks in the 241-A tank farms.

Service Dates: 1955 to 1958 and 1966 to present

Waste Volume: $1.15 \times 10^{9}$ liters

Waste Inventory:

\begin{tabular}{ccc} 
& Total & Decayed Thru June 1976 \\
\cline { 2 - 3 } $\mathrm{Pu}, \mathrm{g}$ & $5.00 \times 10^{1}$ & $5.00 \times 10^{1}$ \\
${ }^{B e t a}, \mathrm{Ci}$ & $1.13 \times 10^{4}$ & $1.55 \times 10^{3}$ \\
${ }^{90} \mathrm{Sr}, \mathrm{Ci}$ & $1.12 \times 10^{2}$ & $7.31 \times 10^{1}$ \\
${ }^{106} \mathrm{Ru}, \mathrm{Ci}$ & $9.95 \times 10^{2}$ & $8.73 \times 10^{-1}$ \\
${ }^{137} \mathrm{Cs}, \mathrm{Ci}$ & $1.08 \times 10^{3}$ & $7.25 \times 10^{2}$ \\
${ }^{60} \mathrm{Co}, \mathrm{Ci}$ & $1.83 \times 10^{0}$ & $2.44 \times 10^{-1}$ \\
$\mathrm{U}, \mathrm{Ci}$ & $<3.68 \times 10^{2}$ & $<3.68 \times 10^{2}$
\end{tabular}

Evaluation of Scintillation Probe Data:

We11s E25-4, E25-5, E25-6,E25-7, E25-8, E25-9 and E25-14 monitor the 216-A-8 crib (figures $A-1$ and A-15). Radioactive contaminants have been detected at the ground surface at a number of wells. In Well E25-4 located at the head end of the crib the radiation intensity increases 4.6 meters above the distributor pipe ( 1.8 meters below the ground surface) (figure A-16). The maximum radiation intensity in the well is 2.1 meters below the distributor pipe. In the remaining wells radiation intensity increases 1.0 to 2.7 meters above the distributor pipe (figures A-17 through A-22). The maximum radiation intensity in these wells coincides with the depth of the distributor pipe.

The long-lived radionuclides are retained high in the sediment column and decrease in concentration from the head end of the crib as evidenced by the reduction of radiation intensity due to radionuclide decay. On the basis of the seven groundwater monitoring structures no measurable migration of radionuclides disposed to the ground from the 216-A-8 crib has been detected from the scintillation probe profiles. These data indicate breakthrough to the groundwater has not occurred at this site. 


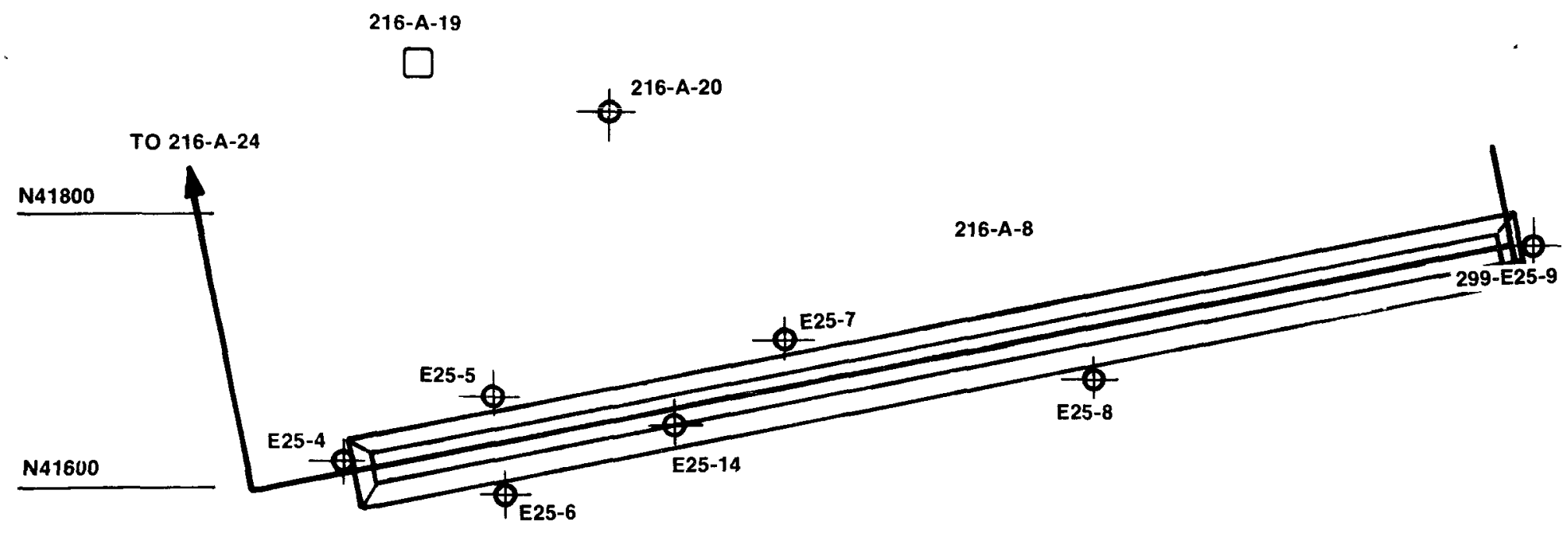

N41400

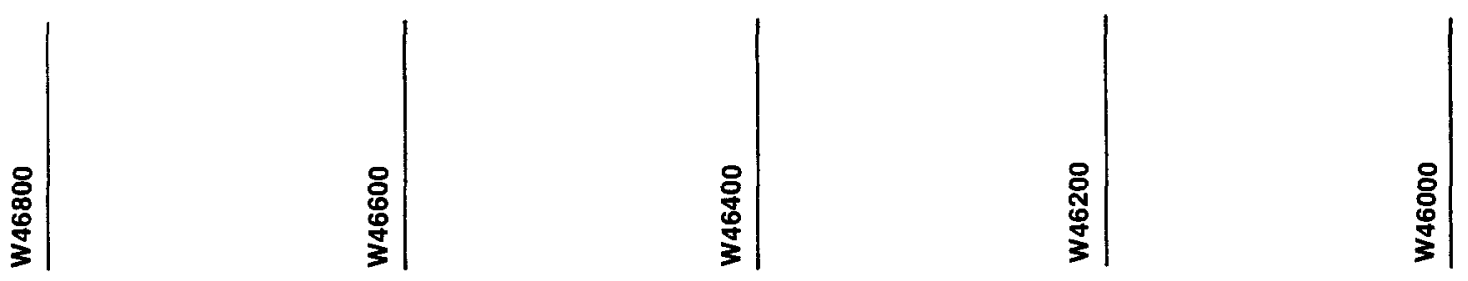

总

216-A-8, 216-A-19 AND 216-A-20

CRIB PLOT PLANS 


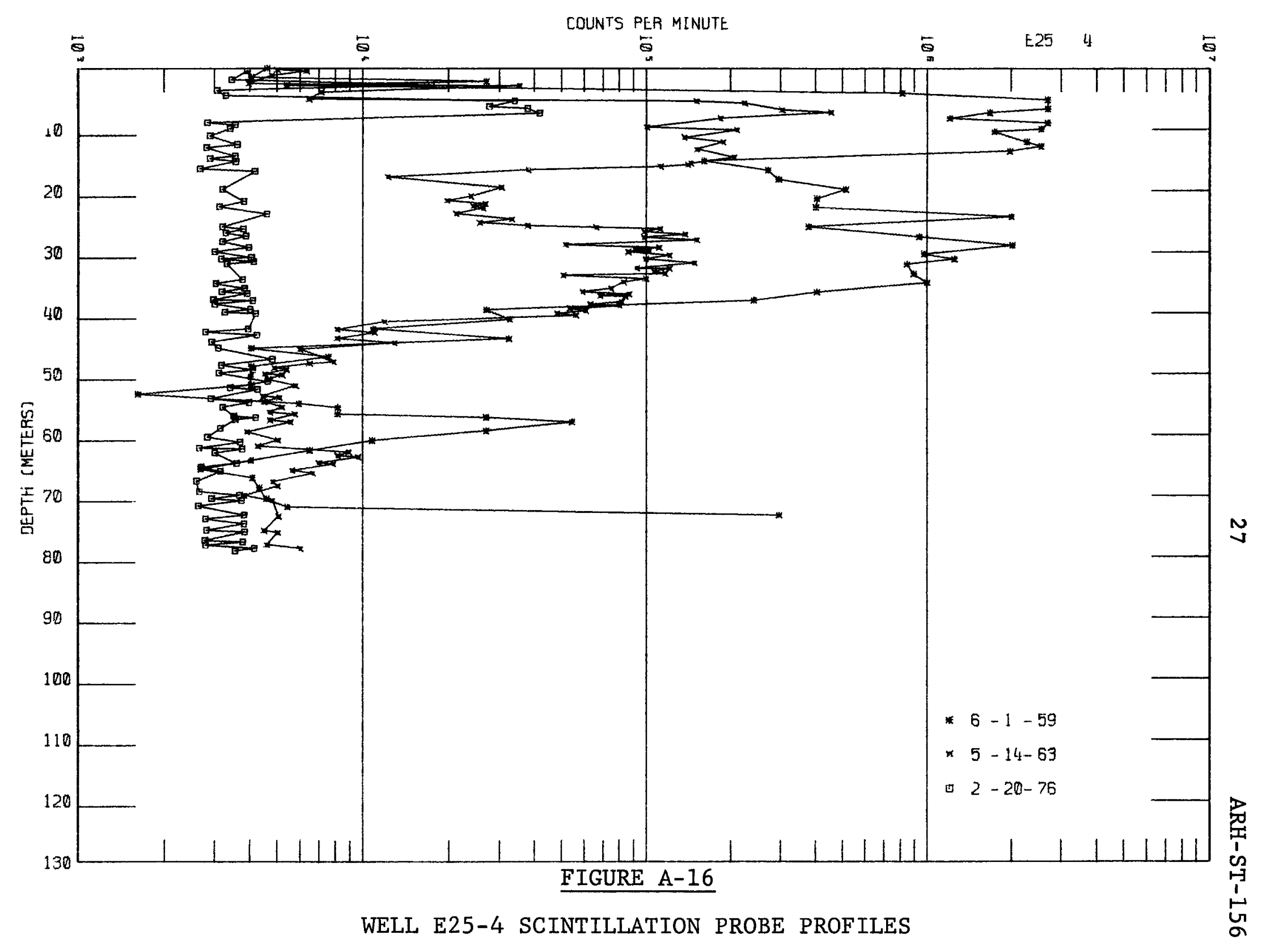




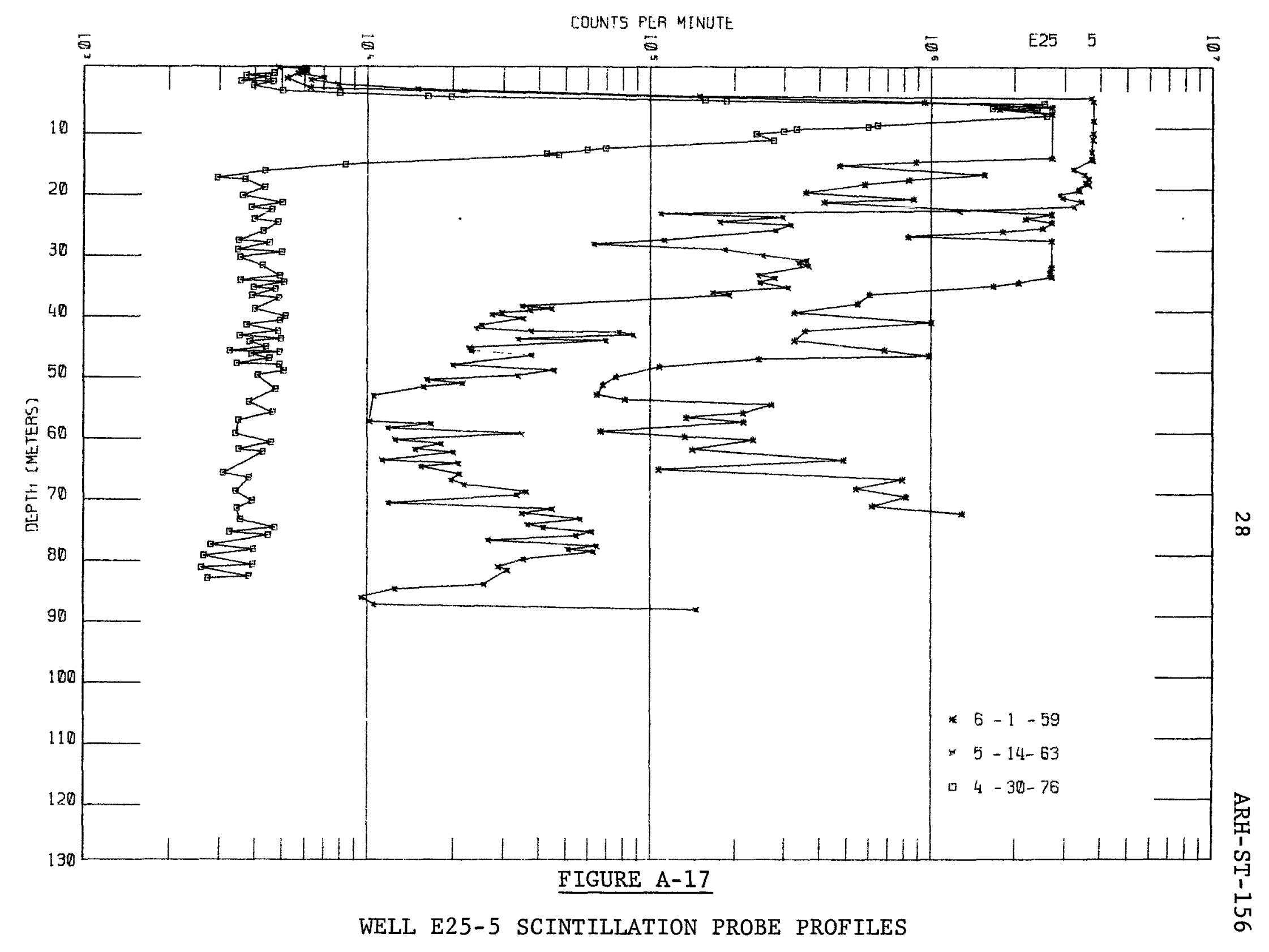




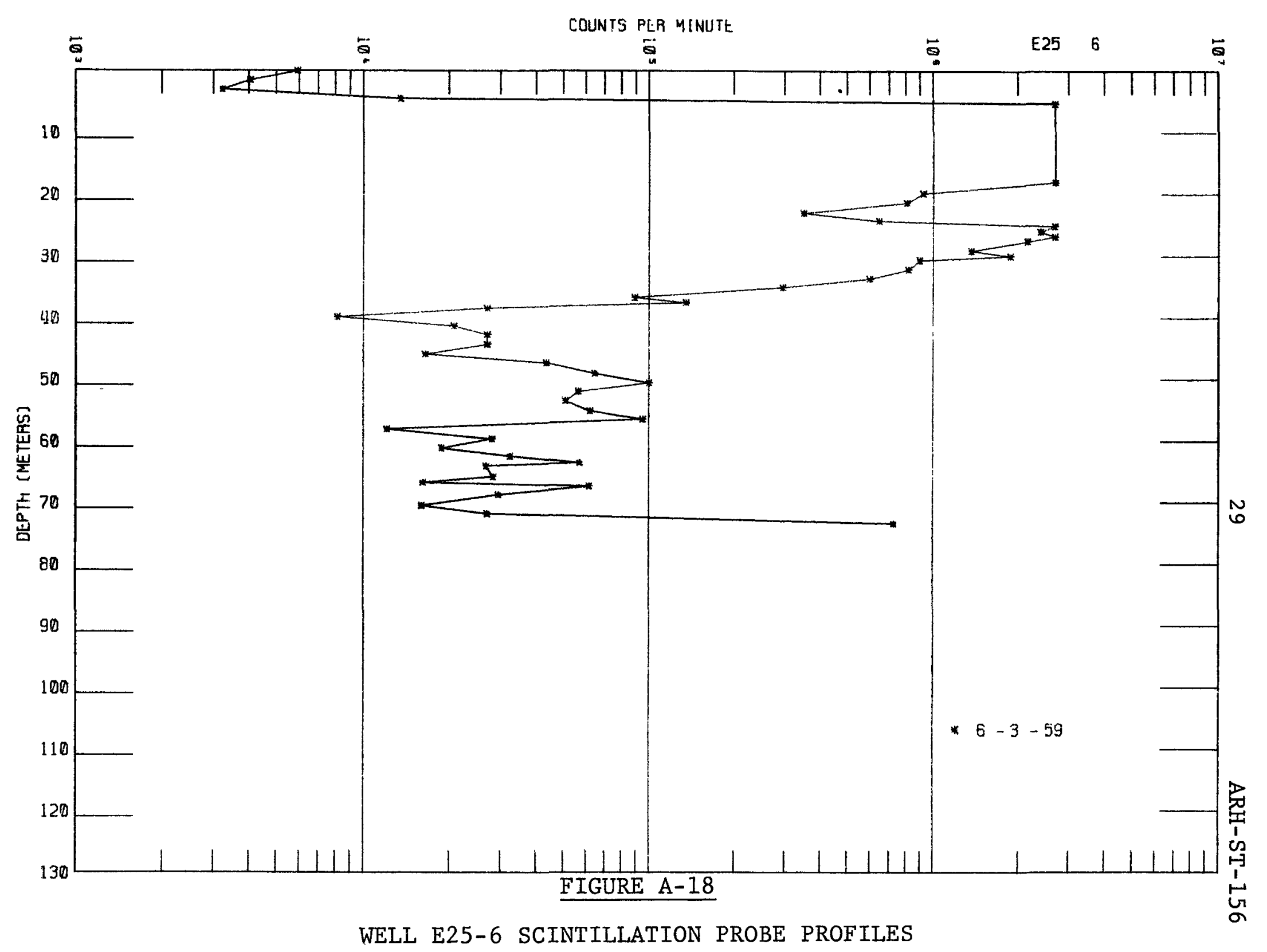




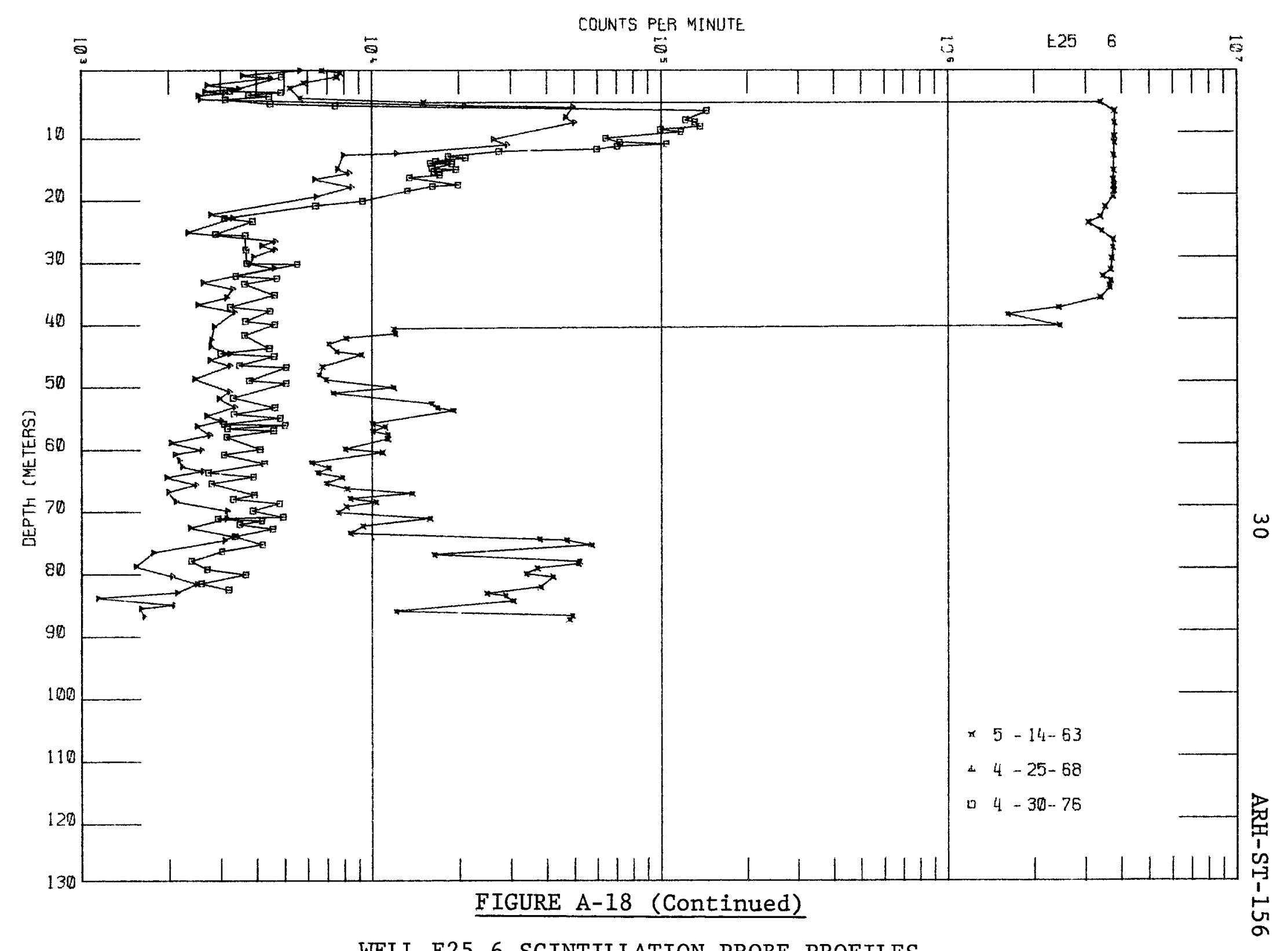

WELL E25-6 SCINTILLATION PROBE PROFILES 


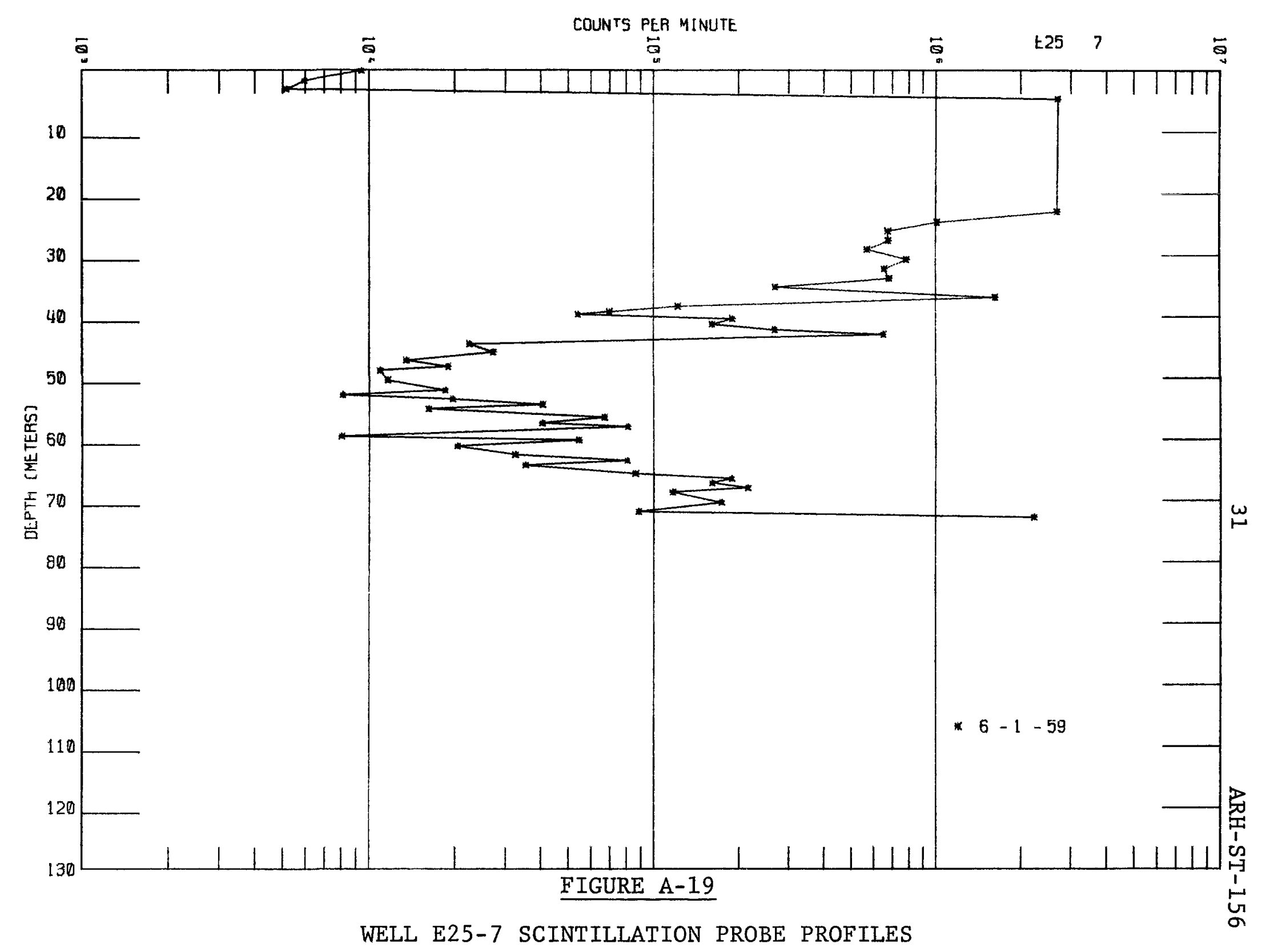




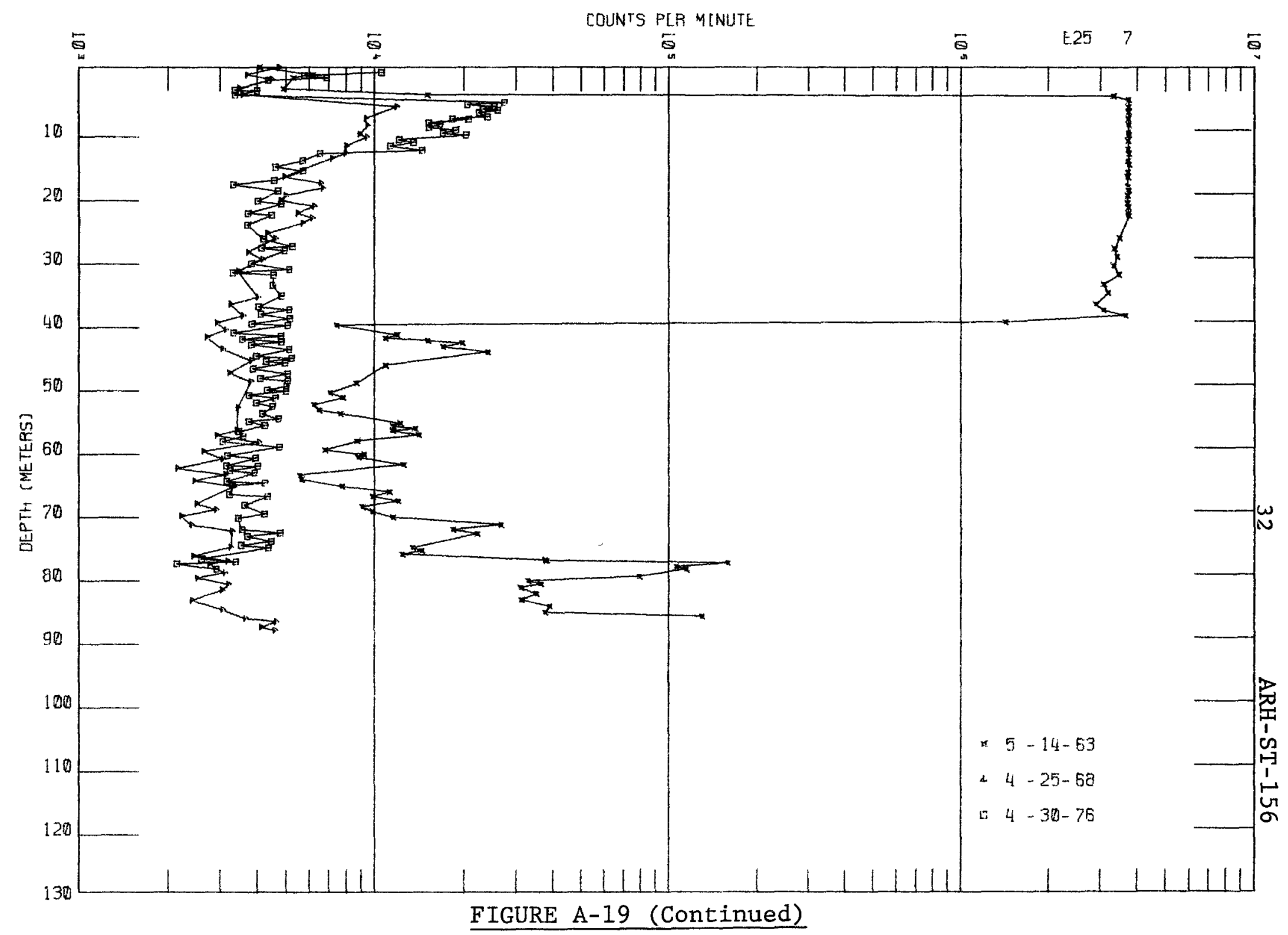

WELL E25-7 SCINTILLATION PROBE PROFILES 


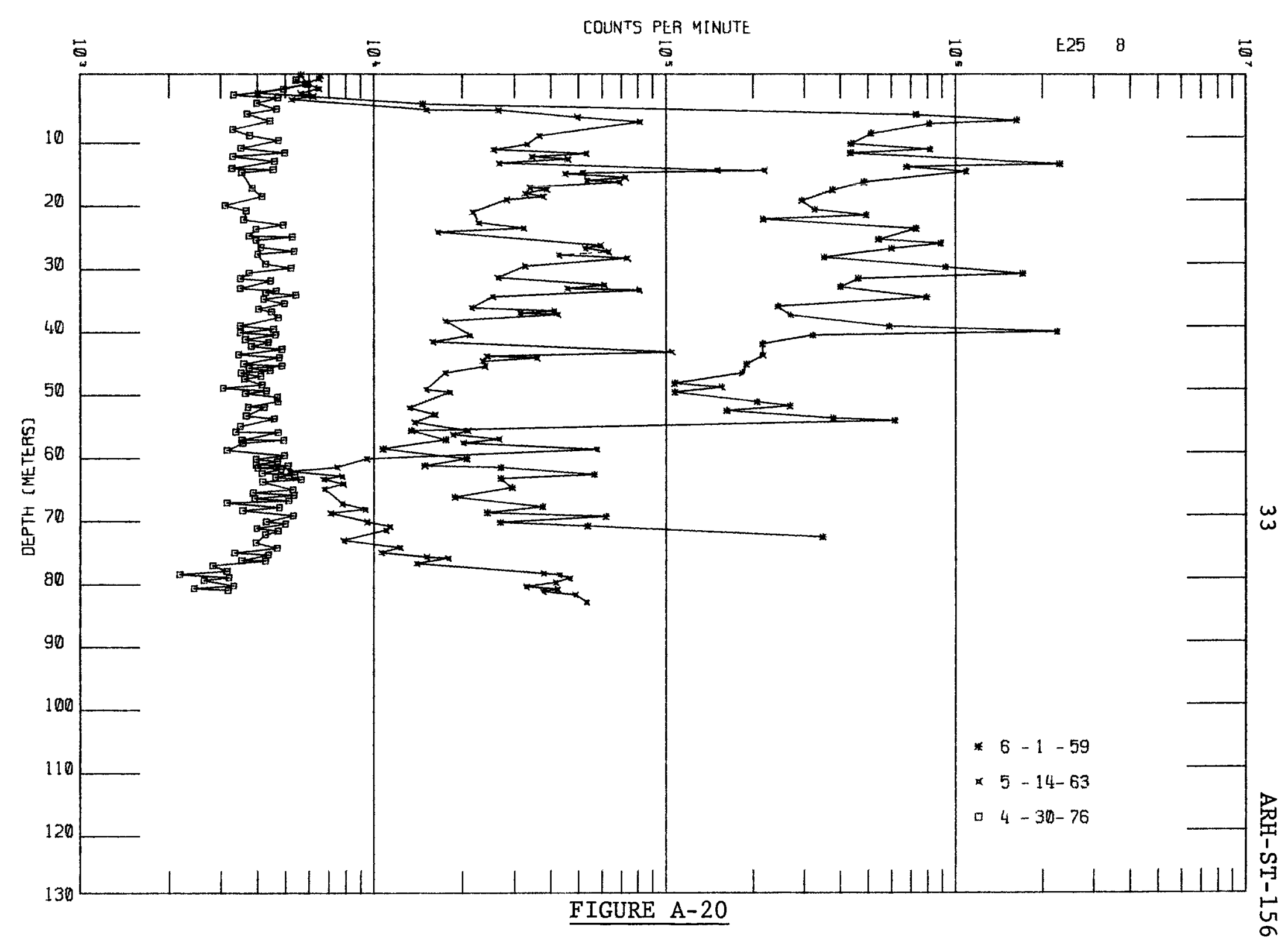

WELL E25-8 SCINTILLATION PROBE PROFILES 


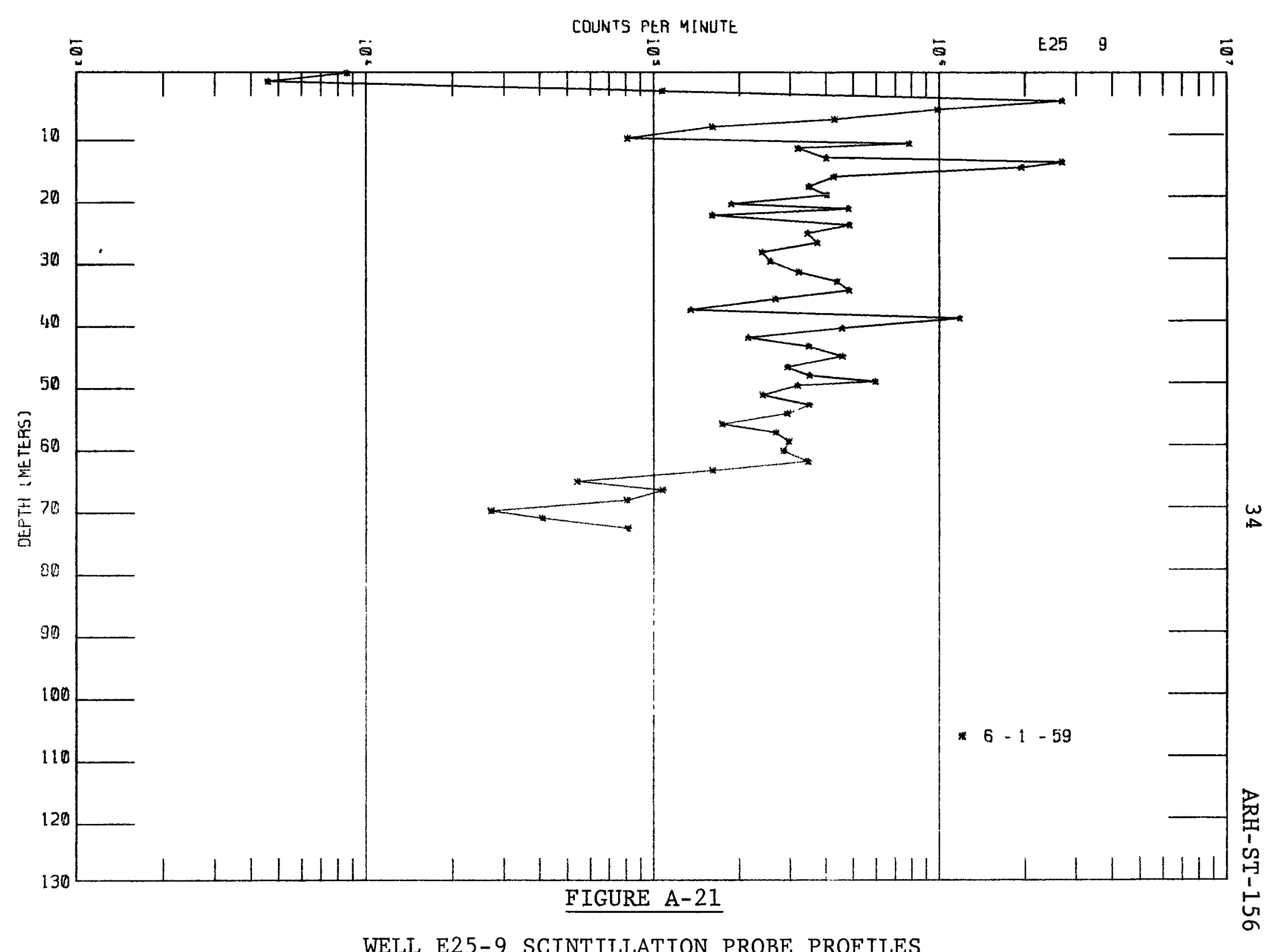

WELL E25-9 SCINTILLATION PROBE PROFILES 


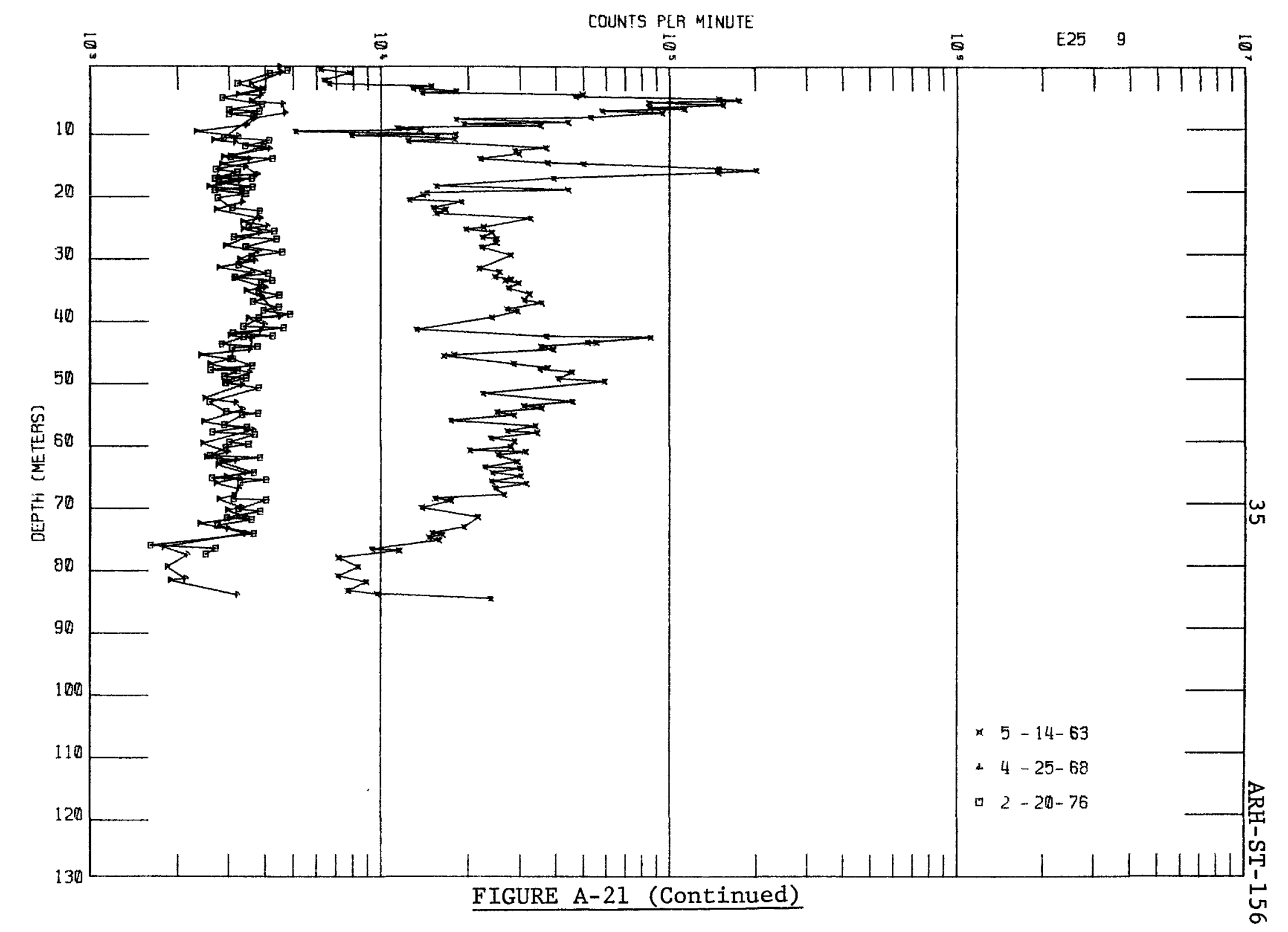

WELL E25-9 SCINTILLATION PROBE PROFILES 
$\theta+i$

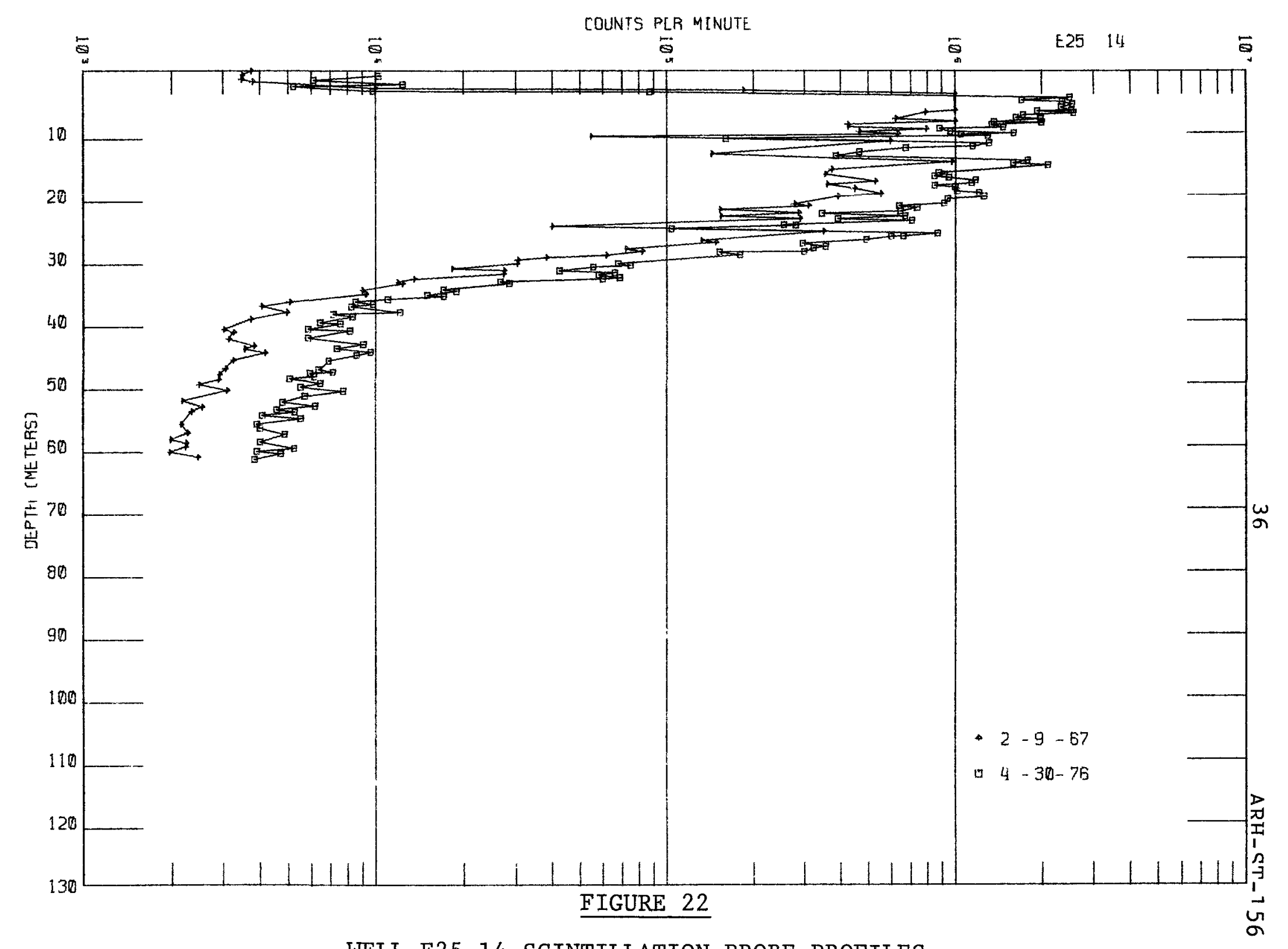

WELL E25-14 SCINTILLATION PROBE PROFILES 


\section{6-A-9 Crib}

Description of Waste: Acid fractionater condensate and condenser cooling water from 202-A; N Reactor decontamination waste; acid fractionater condensate.

Service Dates: 1956 to 1958 and 1966 to 1967

Waste Volume: $9.81 \times 10^{8}$ 1iters

Waste Inventory:

\begin{tabular}{rlc} 
& Total & Decayed Thru June 1976 \\
\cline { 2 - 2 } $\mathrm{Pu}, \mathrm{g}$ & $5.00 \times 10^{-1}$ & $5.00 \times 10^{-1}$ \\
${ }^{\text {Beta }, \mathrm{Ci}}$ & $1.89 \times 10^{2}$ & $4.39 \times 10^{1}$ \\
${ }^{92} \mathrm{Sr}, \mathrm{Ci}$ & $2.50 \times 10^{1}$ & $1.57 \times 10^{1}$ \\
${ }^{106} \mathrm{Ru}, \mathrm{Ci}$ & $5.03 \times 10^{1}$ & $6.77 \times 10^{-4}$ \\
${ }^{137} \mathrm{Cs}, \mathrm{Ci}$ & $1.00 \times 10^{1}$ & $6.46 \times 10^{0}$ \\
${ }^{60} \mathrm{Co}, \mathrm{Ci}$ & $1.40 \times 10^{-1}$ & $2.04 \times 10^{-2}$ \\
$\mathrm{U}, \mathrm{Kg}$ & $2.27 \times 10^{-1}$ & $2.27 \times 10^{-1}$
\end{tabular}

Evaluation of Scintillation Probe Profiles:

Wells E24-3, E24-4, E24-5 and E24-63 monitor the 216-A-9 condensate crib (figures $A-1$ and $A-23$ ). In 1963 radioactive contaminants were detected in wells E24-3 and E24-4, 6.7 meters below the distributor pipe 9.8 meters below the ground surface) (figures A-24 and A-25). The maximum radiation intensity was 8.2 meters below the distributor pipe. In 1976 the radiation intensity is near background (figures A-24 through A-27). These data indicate that breakthrough to the groundwater has not occurred at this site. 


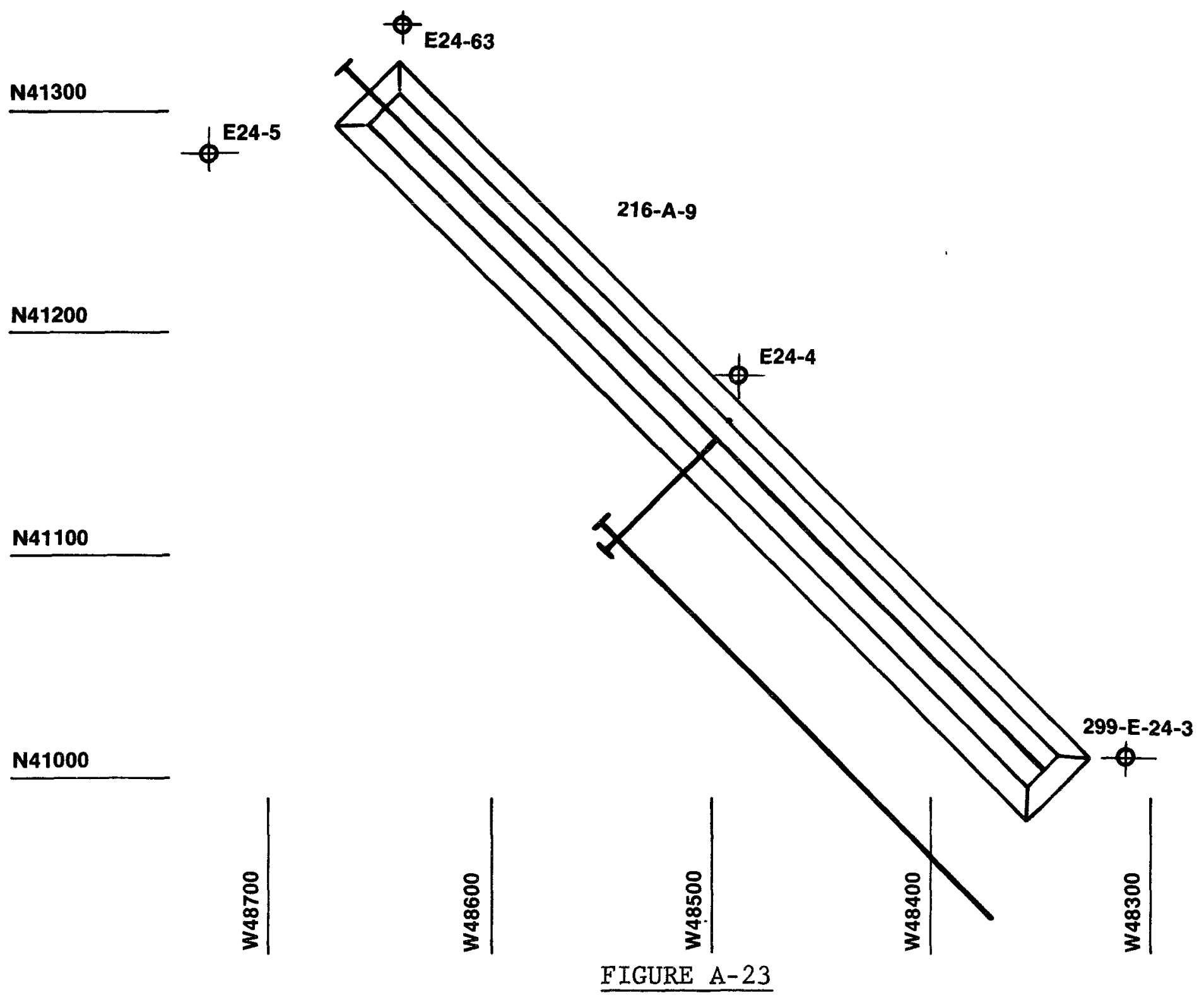

216-A-9 CRIB PLOT PLAN 


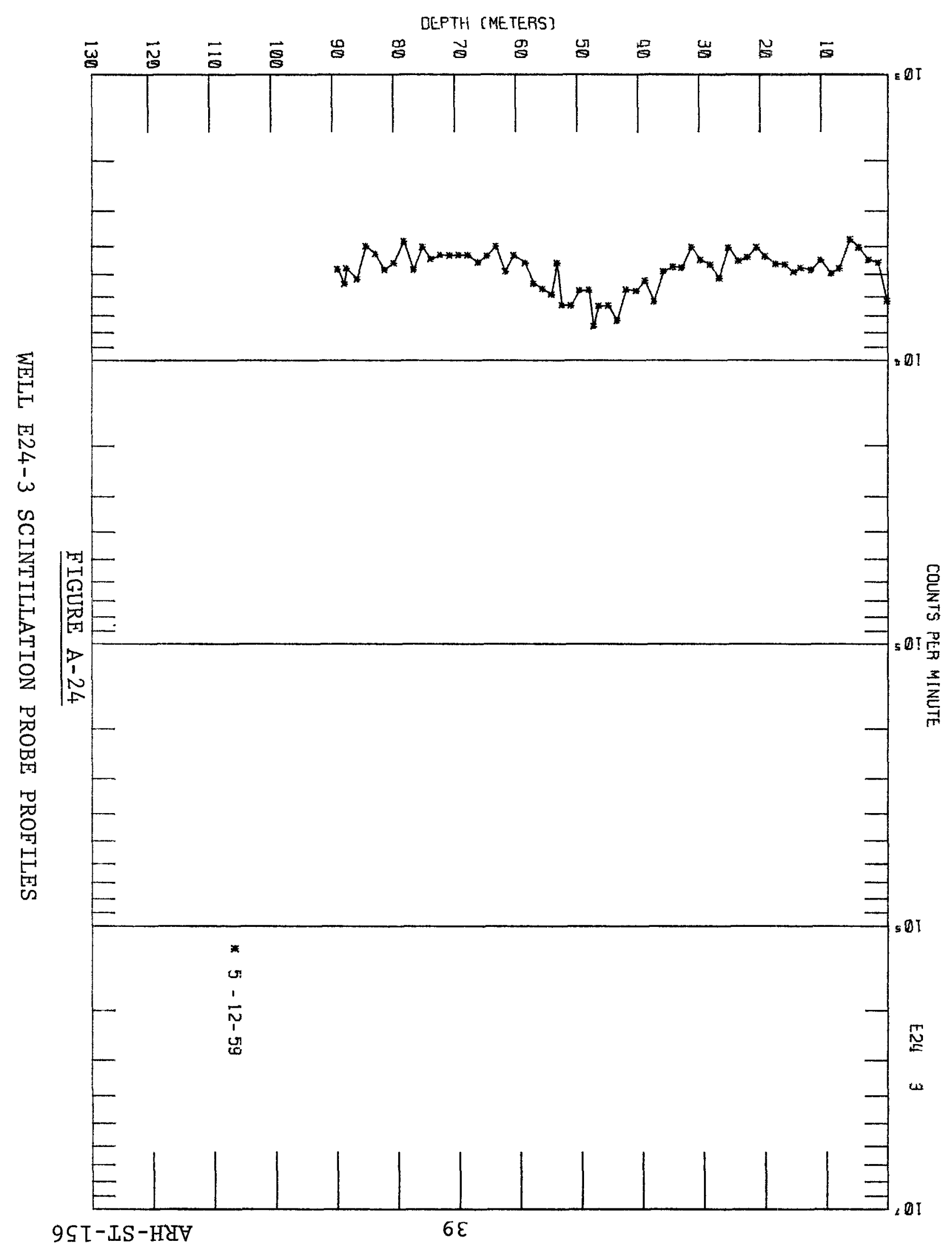




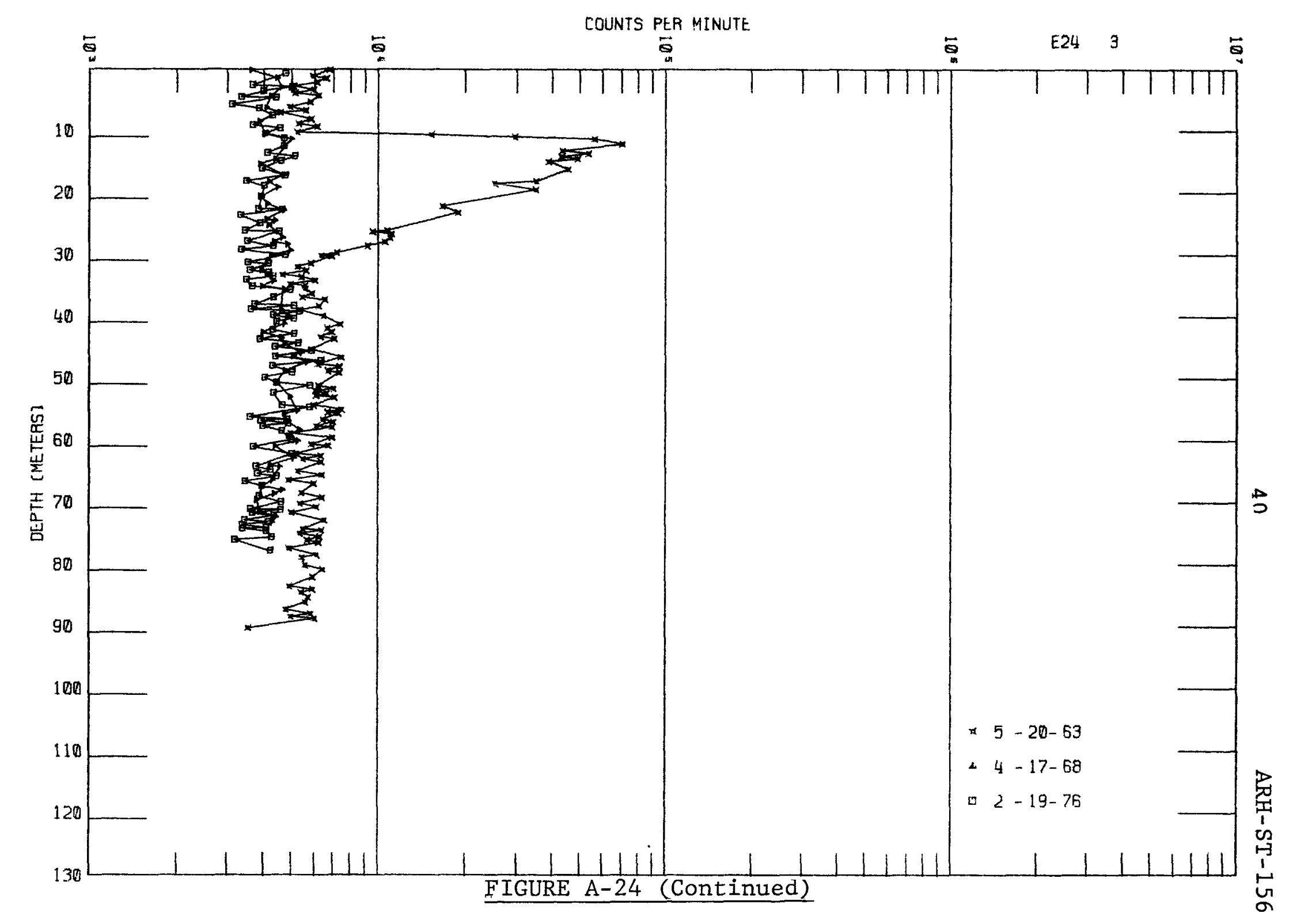

WELL E24-3 SCINTILLATION PROBE PROFILES 
C.

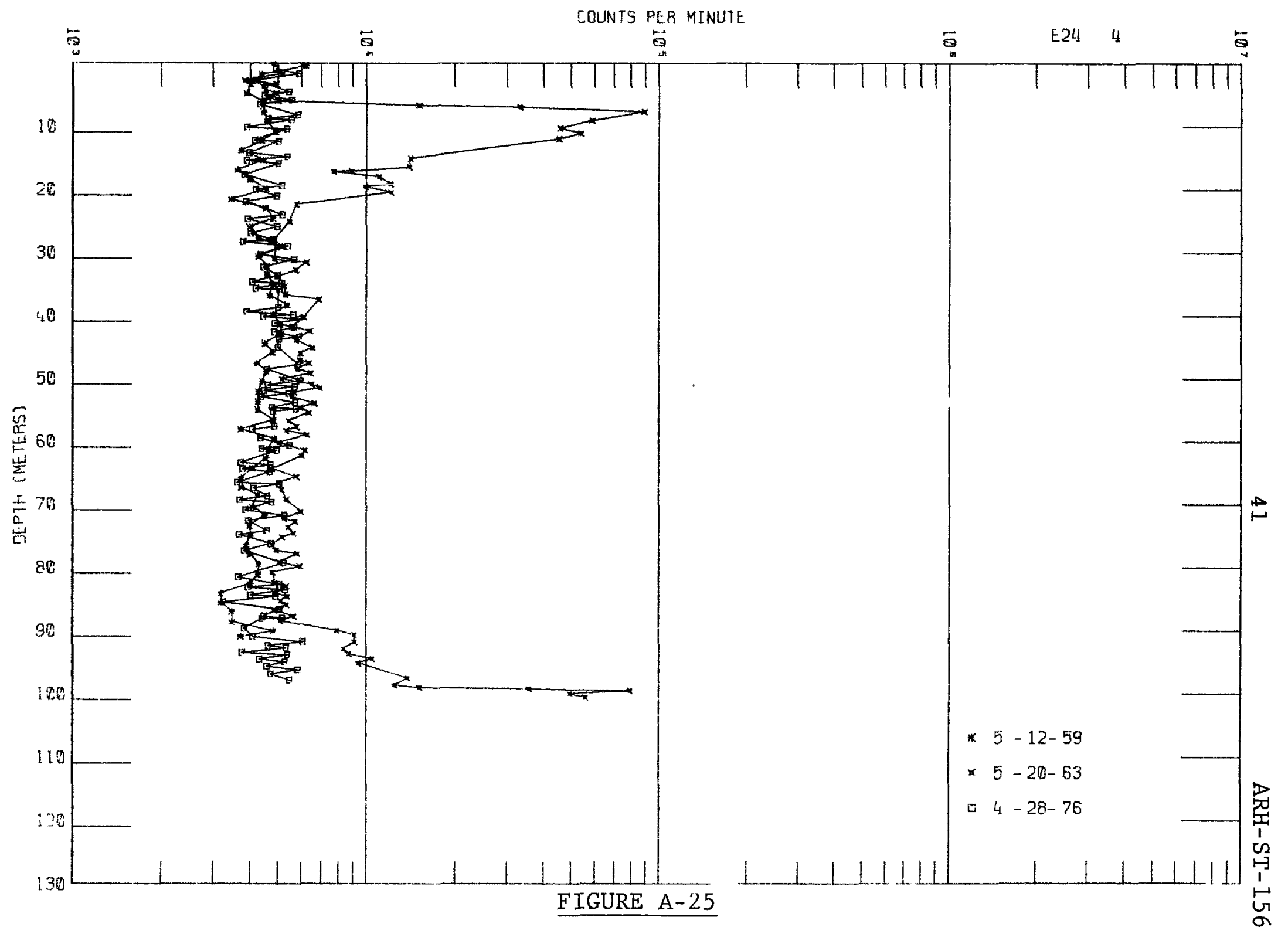

WELL E24-4 SCINTILLATION PROBE PROFILES 


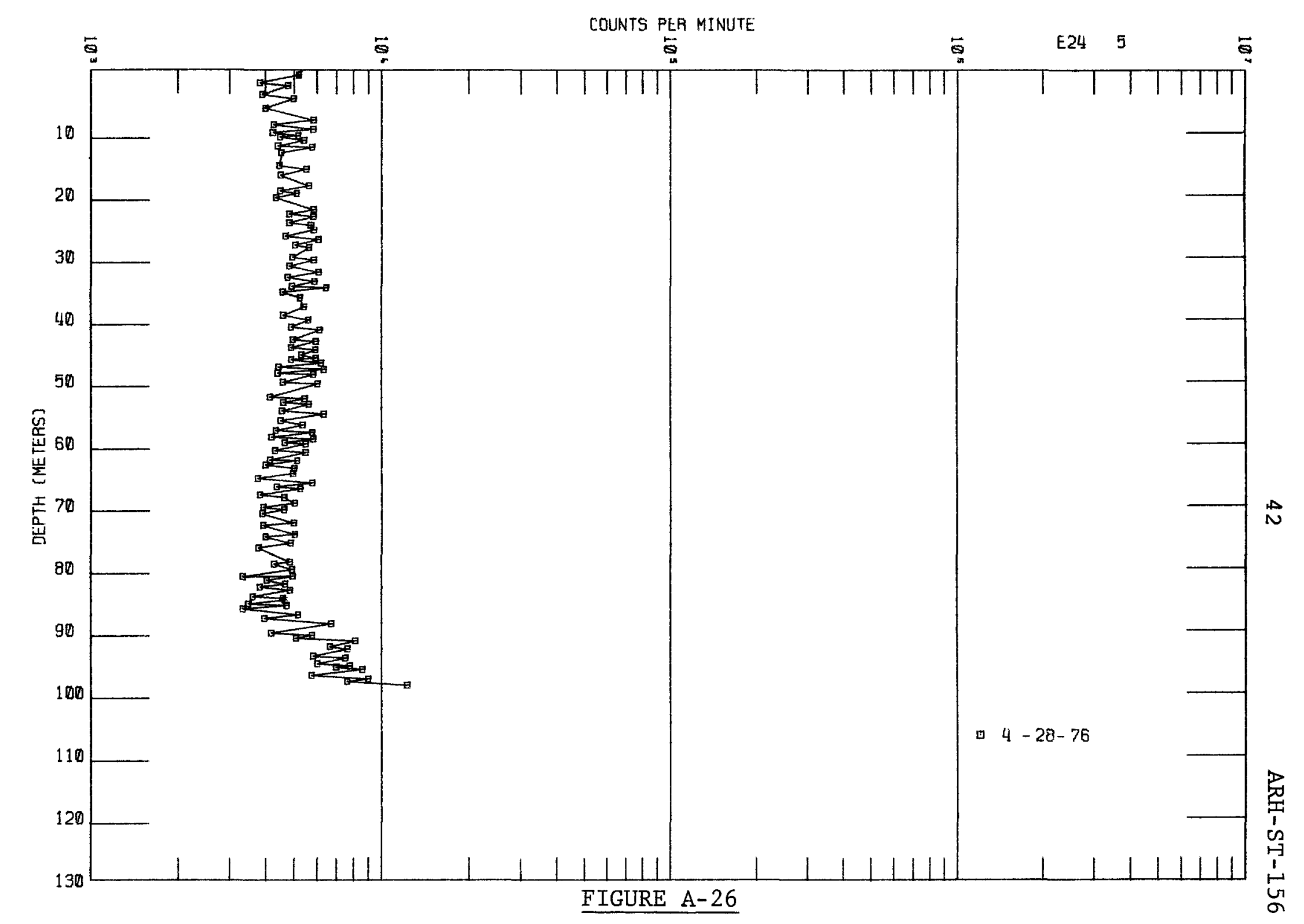

WELL E24-5 SCINTILLATION PROBE PROFILES 


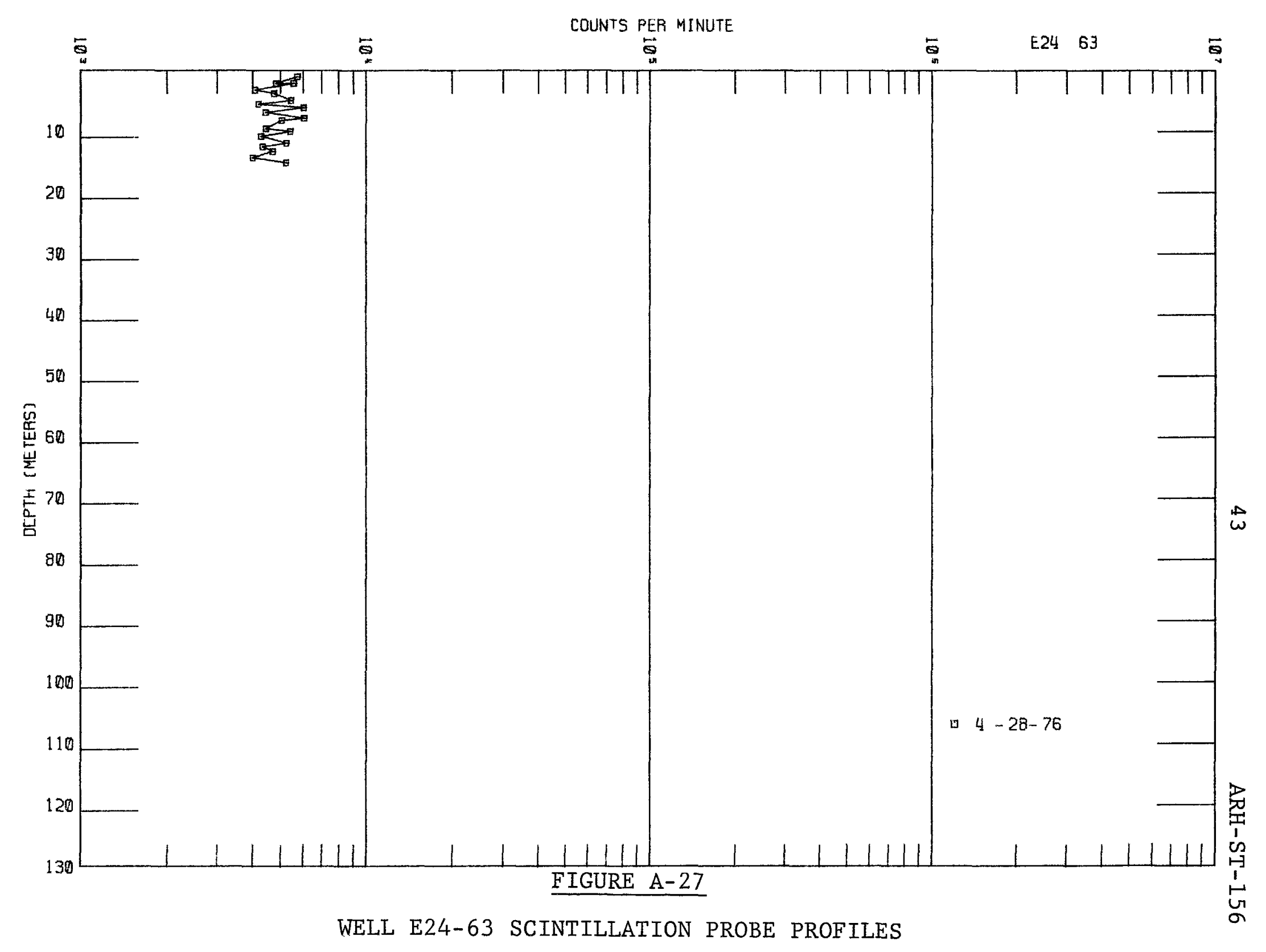




\section{$216-\mathrm{A}-10 \mathrm{Crib}$}

Description of Waste: Process condensate from 202-A.

Service Dates: 1956 and 1961 to 1973

Waste Volume: $2.87 \times 10^{9}$ liters

Waste Inventory:

\begin{tabular}{ccc} 
& Total & Decayed Thru June 1976 \\
\cline { 2 - 3 } $\mathrm{Pu}, \mathrm{g}$ & $3.43 \times 10^{2}$ & $3.43 \times 10^{2}$ \\
${ }^{\text {Beta, }} \mathrm{Ci}$ & $8.06 \times 10^{5}$ & $1.87 \times 10^{3}$ \\
${ }^{90} \mathrm{Sr}, \mathrm{Ci}$ & $1.47 \times 10^{2}$ & $1.17 \times 10^{2}$ \\
${ }^{106} \mathrm{Ru}, \mathrm{Ci}$ & $7.27 \times 10^{3}$ & $2.18 \times 10^{1}$ \\
${ }^{137} \mathrm{Cs}, \mathrm{Ci}$ & $1.34 \times 10^{2}$ & $1.11 \times 10^{2}$ \\
${ }^{60} \mathrm{Co}, \mathrm{Ci}$ & $1.79 \times 10^{2}$ & $3.48 \times 10^{7}$ \\
$\mathrm{U}, \mathrm{Kg}$ & $2.04 \times 10^{2}$ & $2.04 \times 10^{2}$ \\
${ }^{233} \mathrm{U}, \mathrm{g}$ & $2.77 \times 10^{2}$ & $2.77 \times 10^{2}$
\end{tabular}

Evaluation of Scintillation Probe Profiles:

We11s E17-1, E24-2, E24-59 and E24-60 monitor the 216-A-10 process condensate crib (figures $A-1$ and $A-7$ ). The crib has received a total of $2.87 \times 10^{9}$ liters and $1.32 \times 10^{5}$ total beta curies of Purex process condensate from 1961 to 1973. Table I shows the disposal to the crib over the 13 year period from 1961 to 1973.

TABLE A-I

216-A-10 Crib Disposal Record

\begin{tabular}{|c|c|c|}
\hline Year & $\begin{array}{c}\text { Volume } \\
10^{6} \text { liters } \\
\end{array}$ & $\begin{array}{c}\text { Total Beta } \\
\text { Curies } \\
\end{array}$ \\
\hline $\begin{array}{l}1961 \\
1962 \\
1963 \\
1964 \\
1965 \\
1966 \\
1967 \\
1968 \\
1969 \\
1970 \\
1971 \\
1972 \\
1973\end{array}$ & $\begin{array}{r}16 \\
392 \\
306 \\
377 \\
424 \\
286 \\
312 \\
258 \\
117 \\
48 \\
66 \\
29 \\
15\end{array}$ & $\begin{array}{r}114 \\
56,000 \\
23,800 \\
20,600 \\
16,600 \\
2,910 \\
6,010 \\
3,230 \\
1,460 \\
254 \\
1,140 \\
96 \\
<1\end{array}$ \\
\hline
\end{tabular}


Although the disposal volume remained approximately the same between 1962 and 1968, the annual total beta activity decreased greatly after 1965. The decrease is reflected in the scintillation probe profiles where signficant reductions are noted in the midportion of the soil column (figures A-28 through A-31).

The primary radiation peaks at approximately 7.6 meters below the distributor pipe show continual increase in thickness and intensity. These increases are due to the retention of the gamma emitting radionuclides held high in the soil column beneath the crib from subsequent discharges of lower level waste.

In 1976 radioactive contaminants are first encountered approxiimately 6.1 meters below the distributor pipe (15.2 meters below the ground surface). Maximum radiation intensity is approximately 7.6 meters below the distributor pipe. The 68.6 meter depth peak probably represents a lense of fine sand or sandy silt which would contain a larger amount of waste per unit volume than the coarser grained sediments above or below.

On the basis of the profiles from the wells adjacent to the crib no measurable migration of radionuclides disposed to the ground from the 216-A-10 crib has been detected. These data indicate breakthrough to the groundwater could have occurred at this site. 


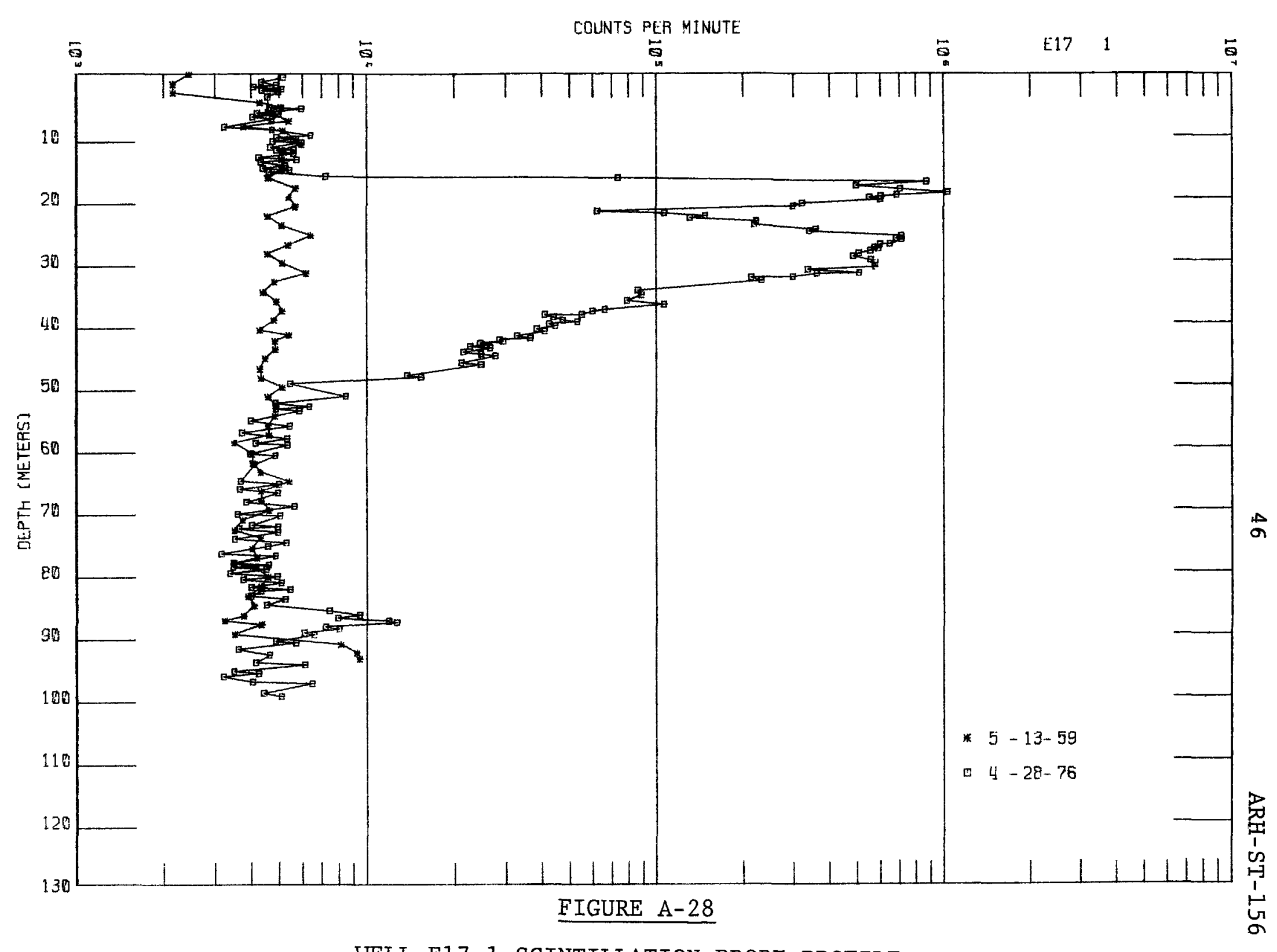

WELL E17-1 SCINTILLATION PROBE PROFILE 


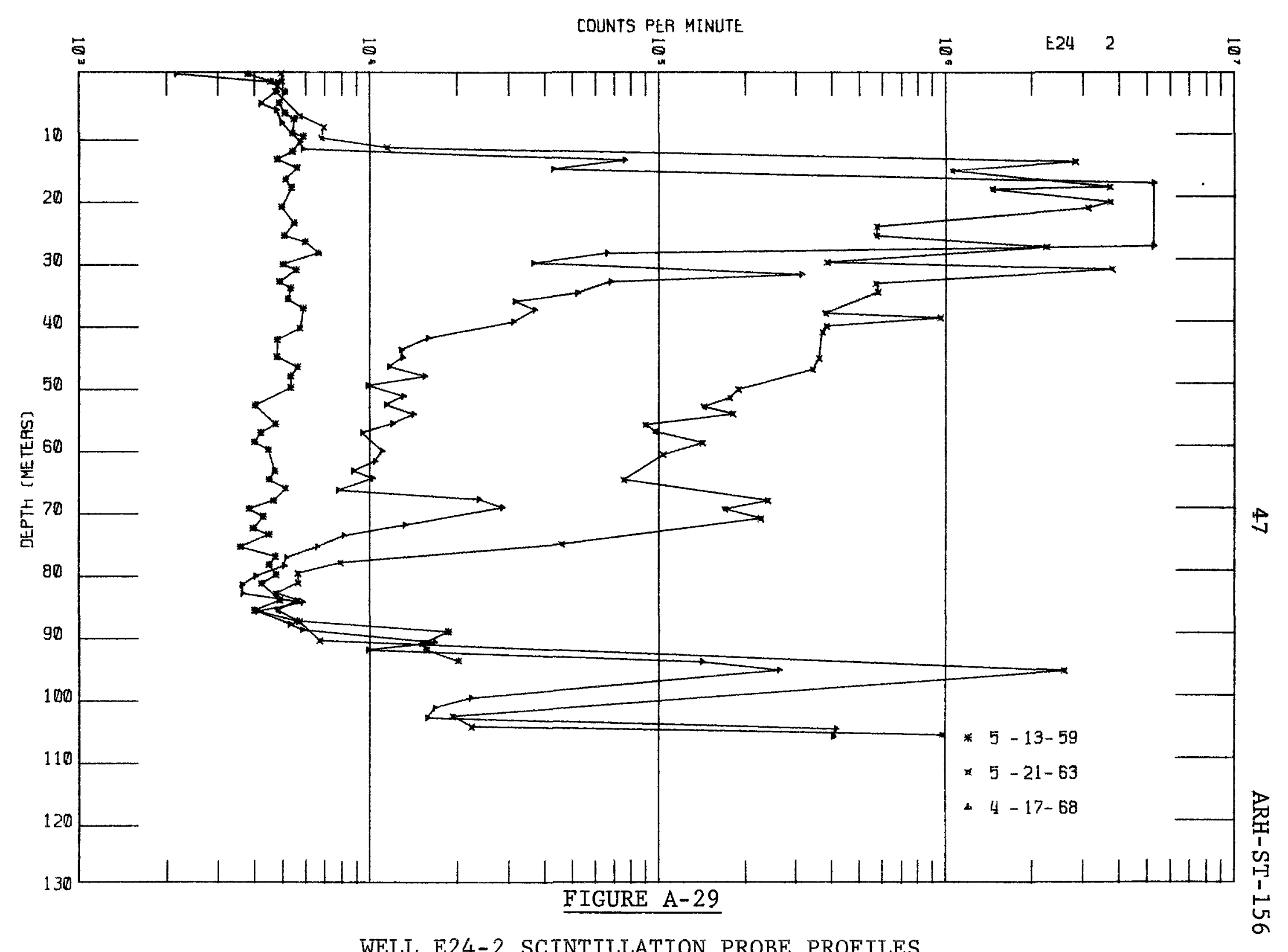

WELL E24-2 SCINTILLATION PROBE PROFILES 


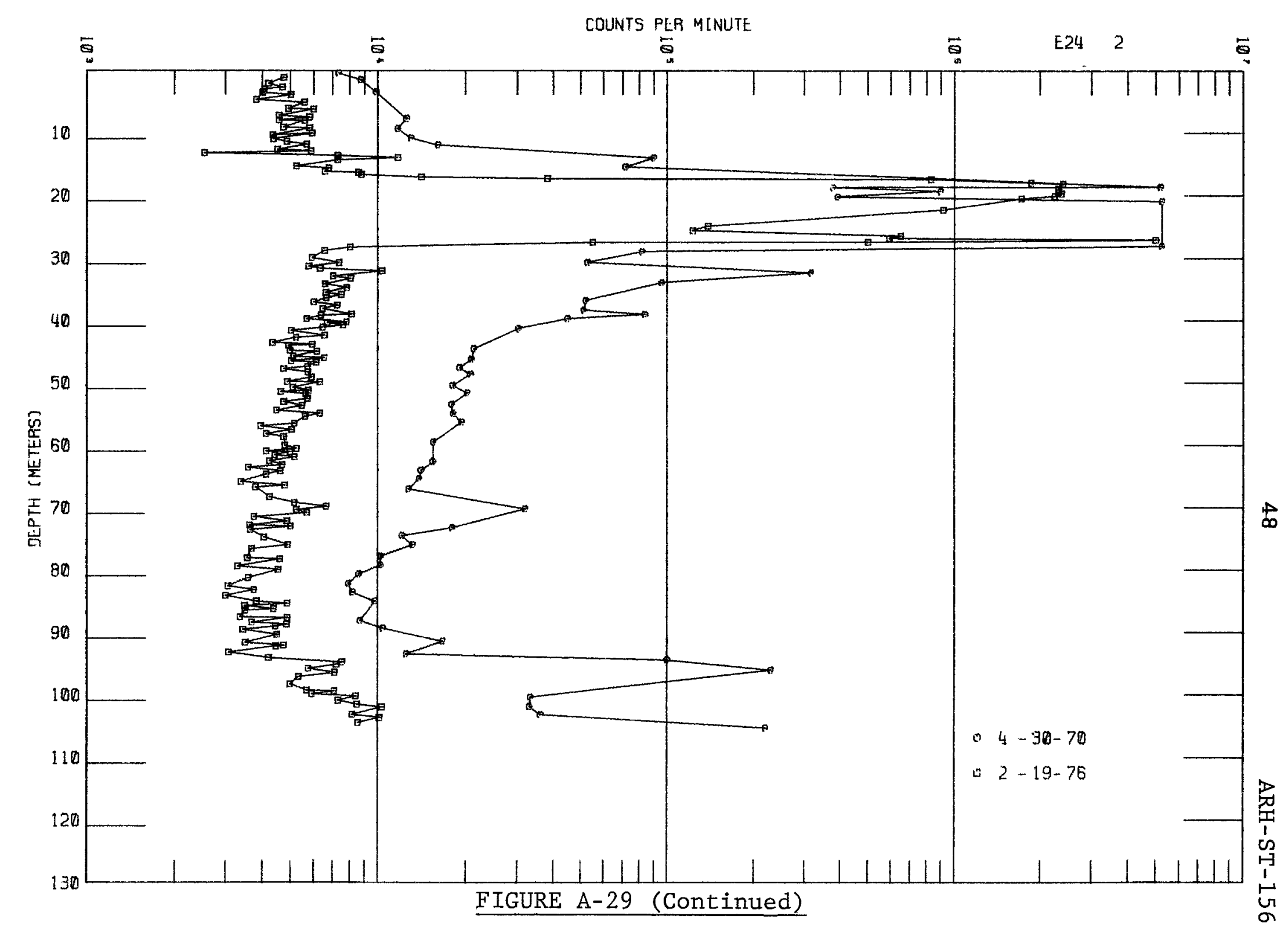

WELL E24-2 SCINTILLATION PROBE PROFILES 


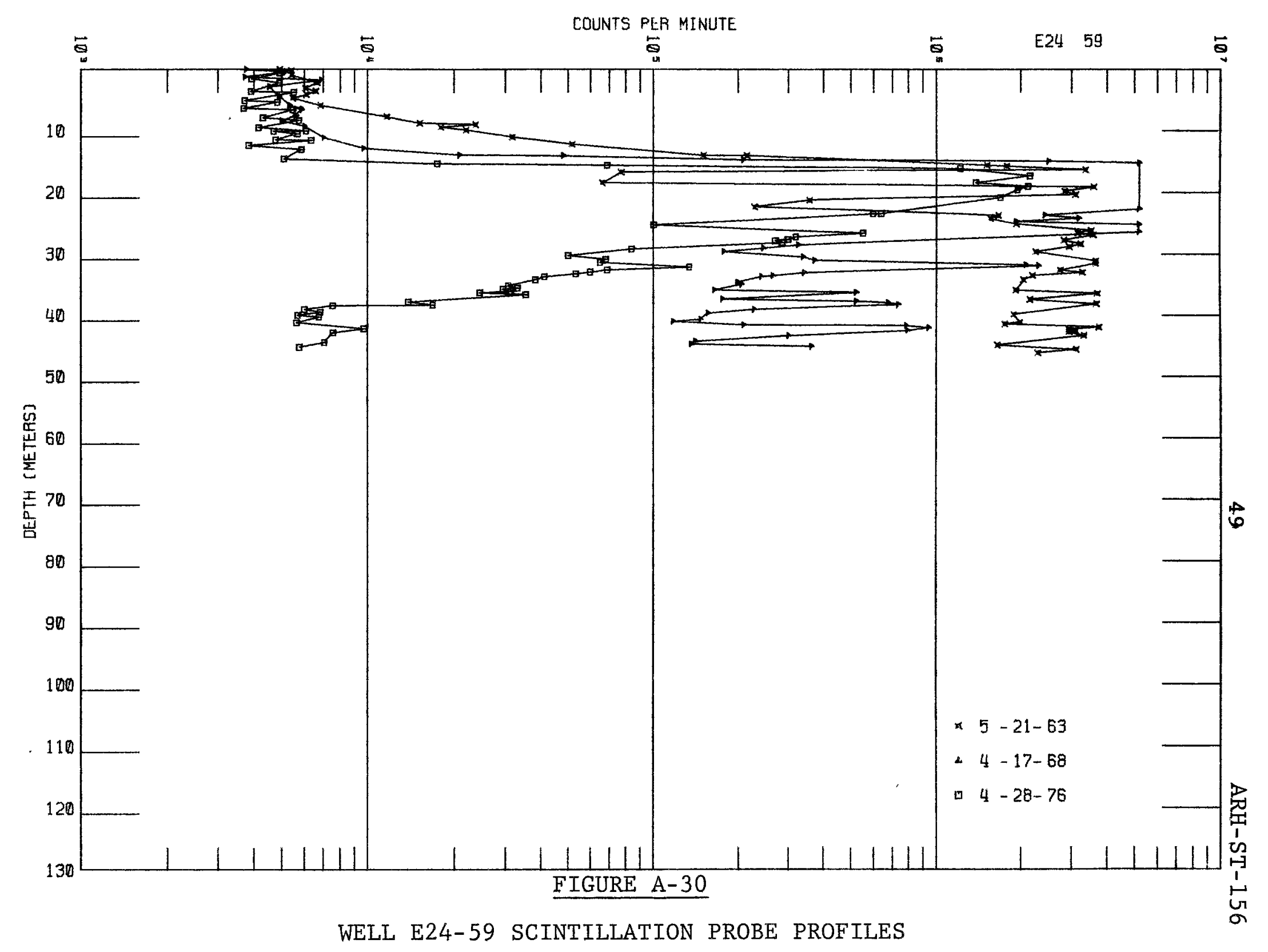




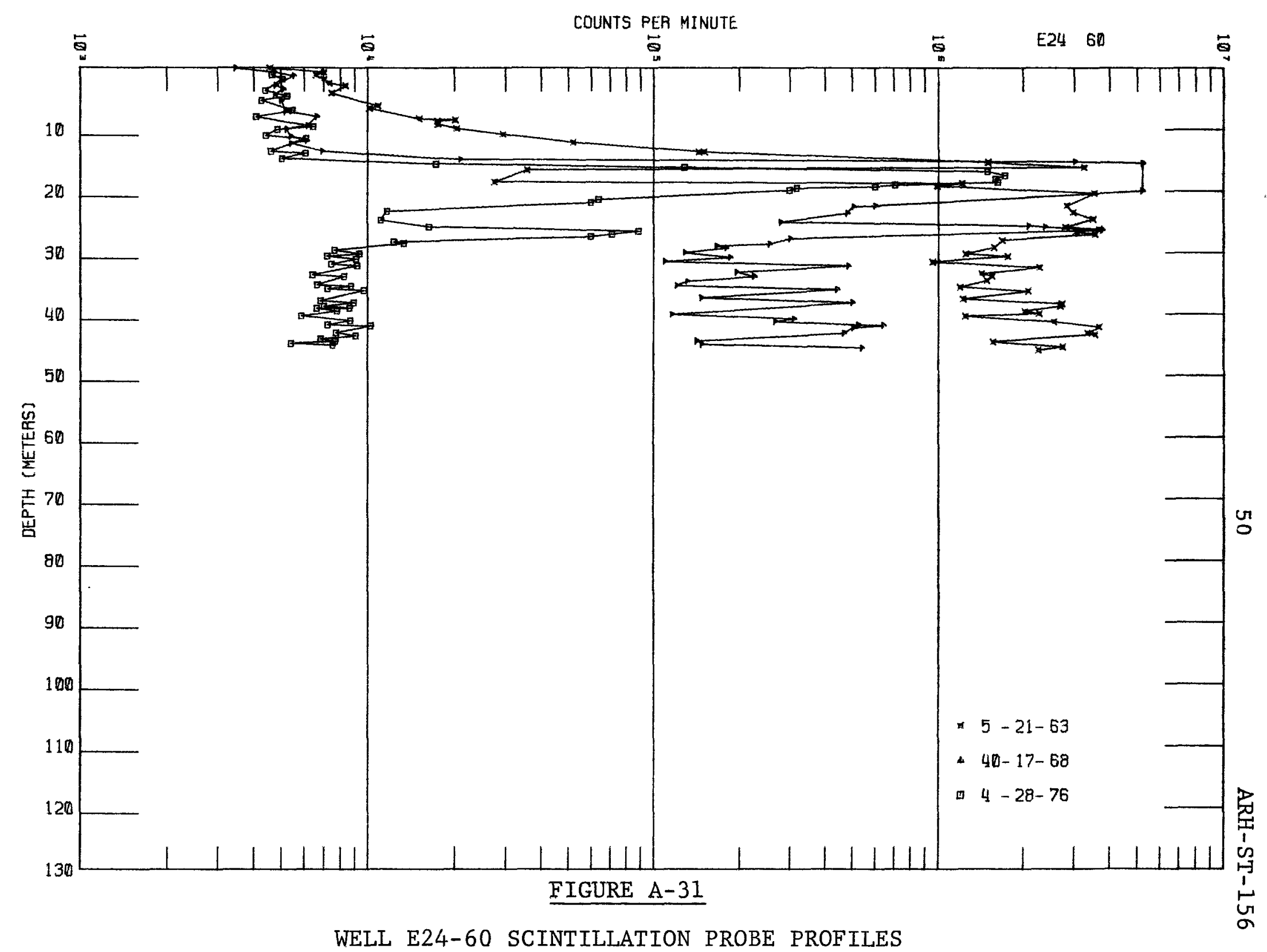




\section{6-A-21 Crib}

Description of Waste: Dump waste from 293-A Building, Purex lab cel1 drainage and 291-A-1 stack drainage.

Service Dates: 1957 to 1965

Waste Volume: $7.78 \times 10^{7}$ liters

Waste Inventory:

\begin{tabular}{rcc} 
& Total & Decayed Thru June 1976 \\
\cline { 2 - 3 } $\mathrm{Pu}, \mathrm{g}$ & $1.50 \times 10^{2}$ & $1.50 \times 10^{2}$ \\
${ }_{\mathrm{Beta}} \mathrm{Ci}$ & $2.80 \times 10^{3}$ & $2.38 \times 10^{2}$ \\
${ }^{90} \mathrm{Sr}, \mathrm{Ci}$ & $1.50 \times 10^{1}$ & $1.07 \times 10^{1}$ \\
${ }^{106} \mathrm{Ru}, \mathrm{Ci}$ & $2.00 \times 10^{2}$ & $2.71 \times 10^{-2}$ \\
${ }^{137} \mathrm{Cs}, \mathrm{Ci}$ & $1.50 \times 10^{2}$ & $1.09 \times 10^{2}$ \\
${ }^{60} \mathrm{Co}, \mathrm{Ci}$ & $1.00 \times 10^{1}$ & $1.65 \times 10^{0}$ \\
U, Kg & $1.95 \times 10^{2}$ & $1.95 \times 10^{2}$
\end{tabular}

Evaluation of Scintillation Probe Profiles:

We11 E24-12 monitors the 216-A-21 crib (figures A-1 and A-4).

The radiation profile shows background radioactivity except a minor peak 41.1 meters below the ground surface (figure A-32). (Well E24-12 is located 22 meters southwest of the end of the distributor pipe). The waste volume and waste inventory indicate breakthrough to the groundwater has not occurred at this site. 


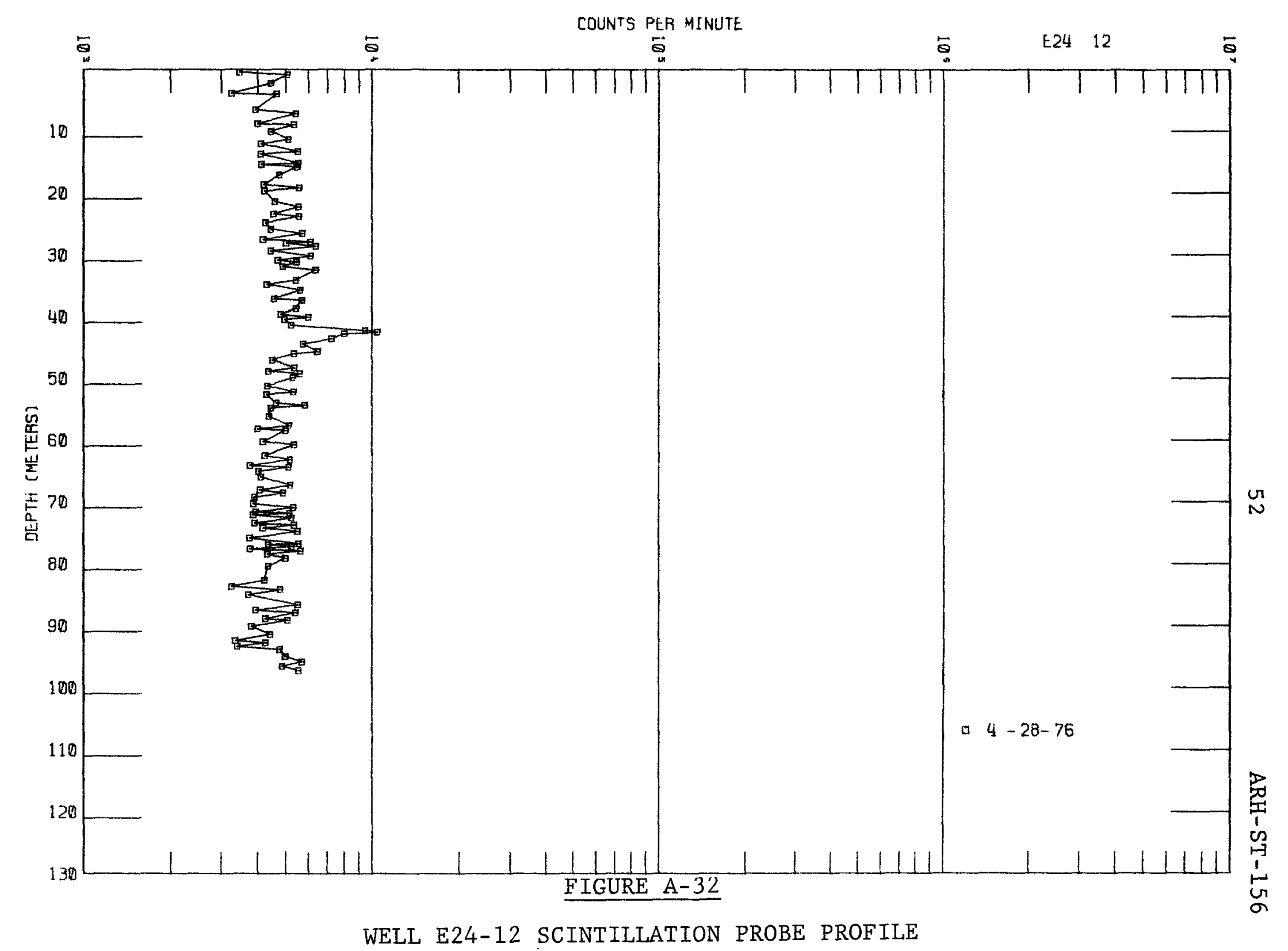




\section{6-A-24 Crib}

Description of Waste: Condensate from waste storage tanks in the 241-A and 241-AX tank farms.

Service Dates: 1958 to 1967

Waste Volume: $8.20 \times 10^{8}$ Titers

Waste Inventory:

\begin{tabular}{ccc} 
& Total & Decayed Thru June 1976 \\
\cline { 2 - 3 } $\mathrm{Pu}, \mathrm{g}$ & $<5.06 \times 10^{0}$ & $<5.06 \times 10^{0}$ \\
${ }_{\text {Beta }, \mathrm{Ci}}$ & $4.98 \times 10^{3}$ & $7.68 \times 10^{2}$ \\
${ }^{90} \mathrm{Sr}, \mathrm{Ci}$ & $3.94 \times 10^{1}$ & $2.60 \times 10^{7}$ \\
${ }^{106} \mathrm{Ru}, \mathrm{Ci}$ & $4.08 \times 10^{2}$ & $2.46 \times 10^{-2}$ \\
${ }^{137} \mathrm{Cs}, \mathrm{Ci}$ & $5.49 \times 10^{2}$ & $3.72 \times 10^{2}$ \\
${ }^{60} \mathrm{Co}, \mathrm{Ci}$ & $7.00 \times 10^{-1}$ & $7.65 \times 10^{-2}$ \\
$\mathrm{U}, \mathrm{Kg}$ & $5.01 \times 10^{1}$ & $5.01 \times 10^{1}$
\end{tabular}

\section{Evaluation of Scintillation Probe Profiles:}

Wells E26-2, E26-3, E26-4, E26-5 and E26-7 monitor the 216-A-24 tank farm condensate crib (figures $A-1$ and $A-33$ ).

Radioactive contaminants detected at the ground surface in wells E26-5 and E26-7 decreased in radiation intensity to background (figures $A-34$ and $A-35)$. The maximum radiation intensity in We11 E26-5, located at the head end of the crib, is 2.4 meters below the distributor pipe (4.6 meters below the ground surface). The radiation intensity at this peak has been decreasing with time. The major zone of radioactive contaminants in We11 E26-7 in 1967 and 1976 are found between 3.6 and 41.1 meters below the ground surface. The radiation intensity in this zone shows very little decrease with time. The peak at 39.6 meters below the ground surface has increase in radiation intensity since 1967 . 
The profile from Well E26-4 shows decreasing radiation intensity in the zone of contamination 9.1 to 27.4 meters below the ground surface (figure A-36). Radioactive contaminants were detected in Wells E26-2 and E26-3 from the ground surface to groundwater in 1963 (figures A-37 and A-38). In 1976 the radiation intensity has decreased to background by the decay of short-lived radionuclides.

The scintillation probe profiles reflect the waste discharge history at this site. We17s E26-4, E25-5 and E26-6 monitor the first and second sections of the crib. These sections received most of the volume $(6.85$ $\times 10^{9}$ liters) and total beta activity $\left(4.21 \times 10^{3}\right.$ curies $)$ discharged during 1958 and 1959 . The profile from these wells show high radiation intensity from these discharges. After December 1959 the volume and the amount of radioactive effluent sent to the crib were greatly reduced. The condensate was later rerouted to the third and fourth crib sections. We11s E26-2 and E26-3 monitor these sections of the crib where little radioactive effluent was discharged. In 1976 these profiles show radiation intensity at background levels.

On the basis of the five wells monitoring the 216-A-24 crib measurable movement of radionuclides disposed to the ground is detected in all wells during crib operations. After waste disposal to the crib was terminated, radiation intensity increased in the lower portion of the sediment column in We11 E26-7. These data indicate breakthrough to the groundwater could have occurred from the first and second sections of the crib. 


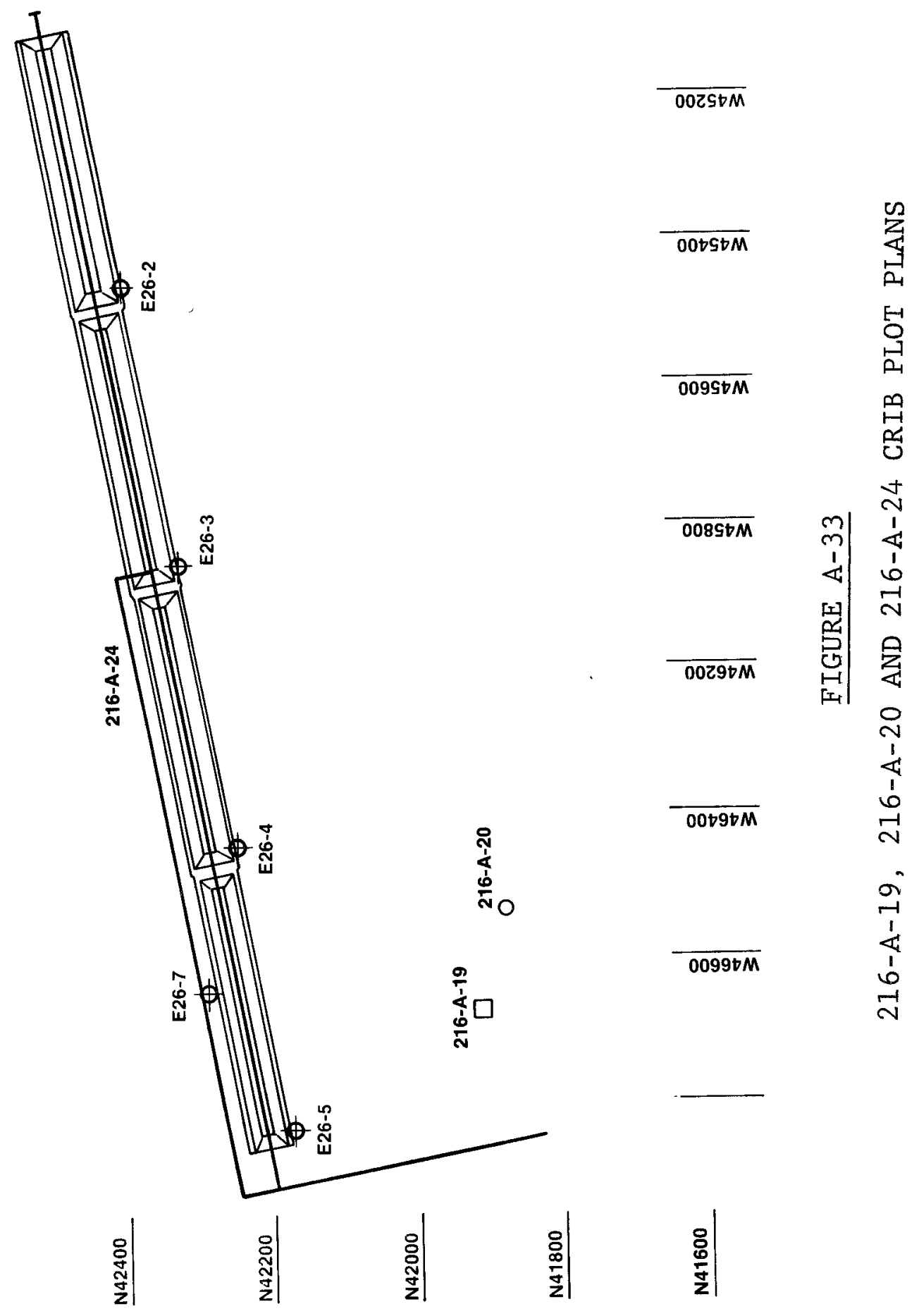




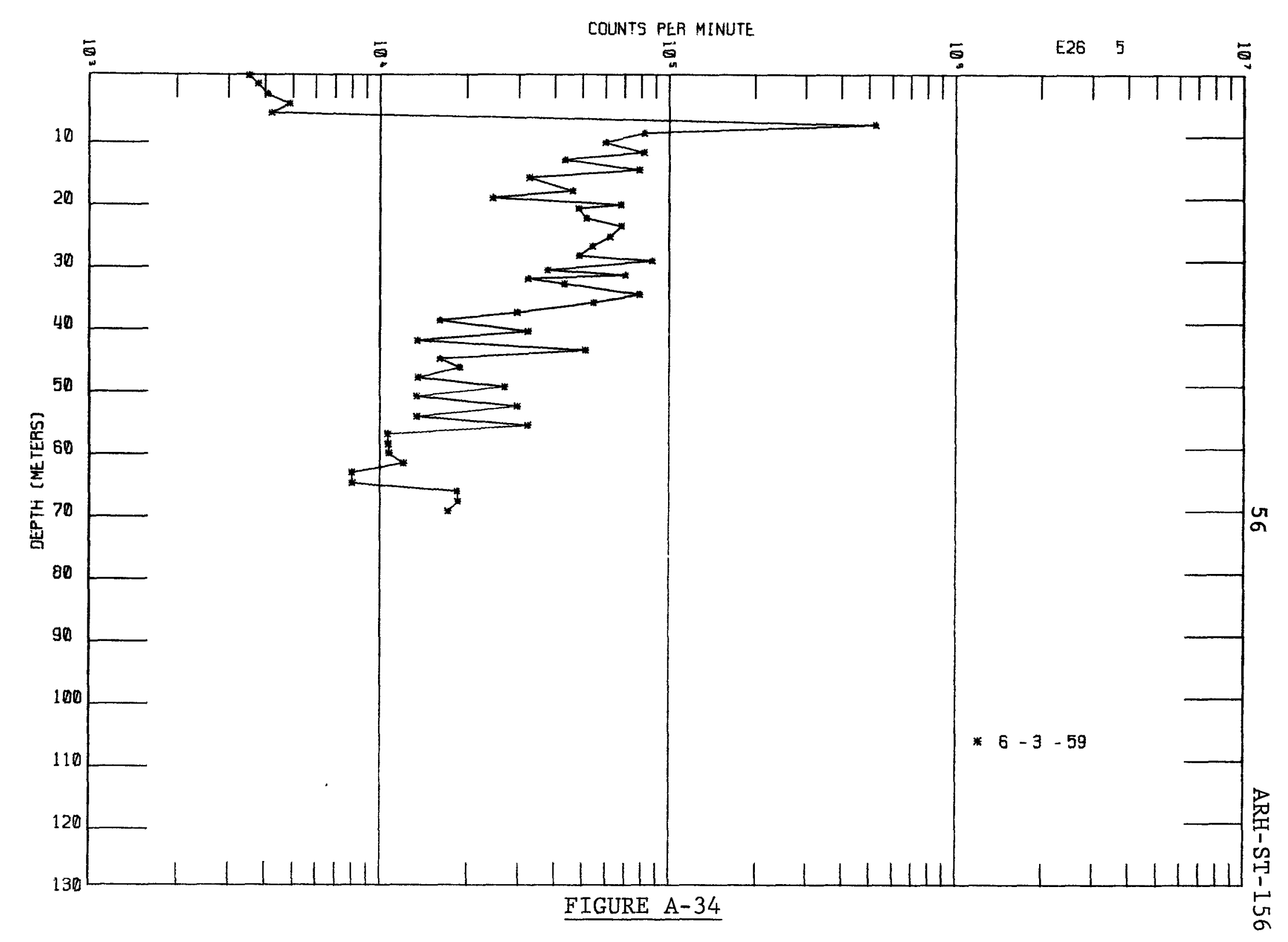

WELL E26-5 SCINTILLATION PROBE PROFILES 


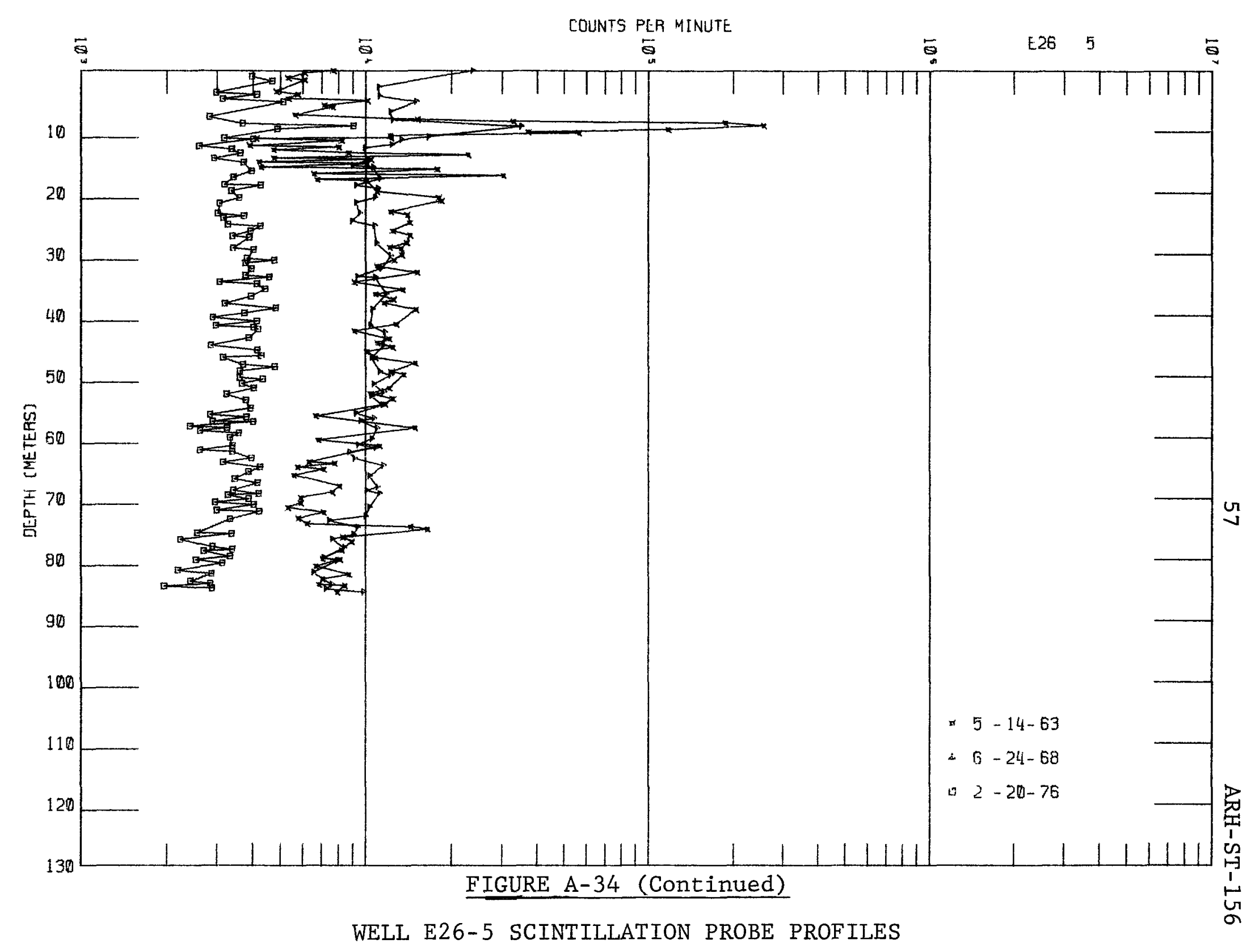


$\rightarrow+$

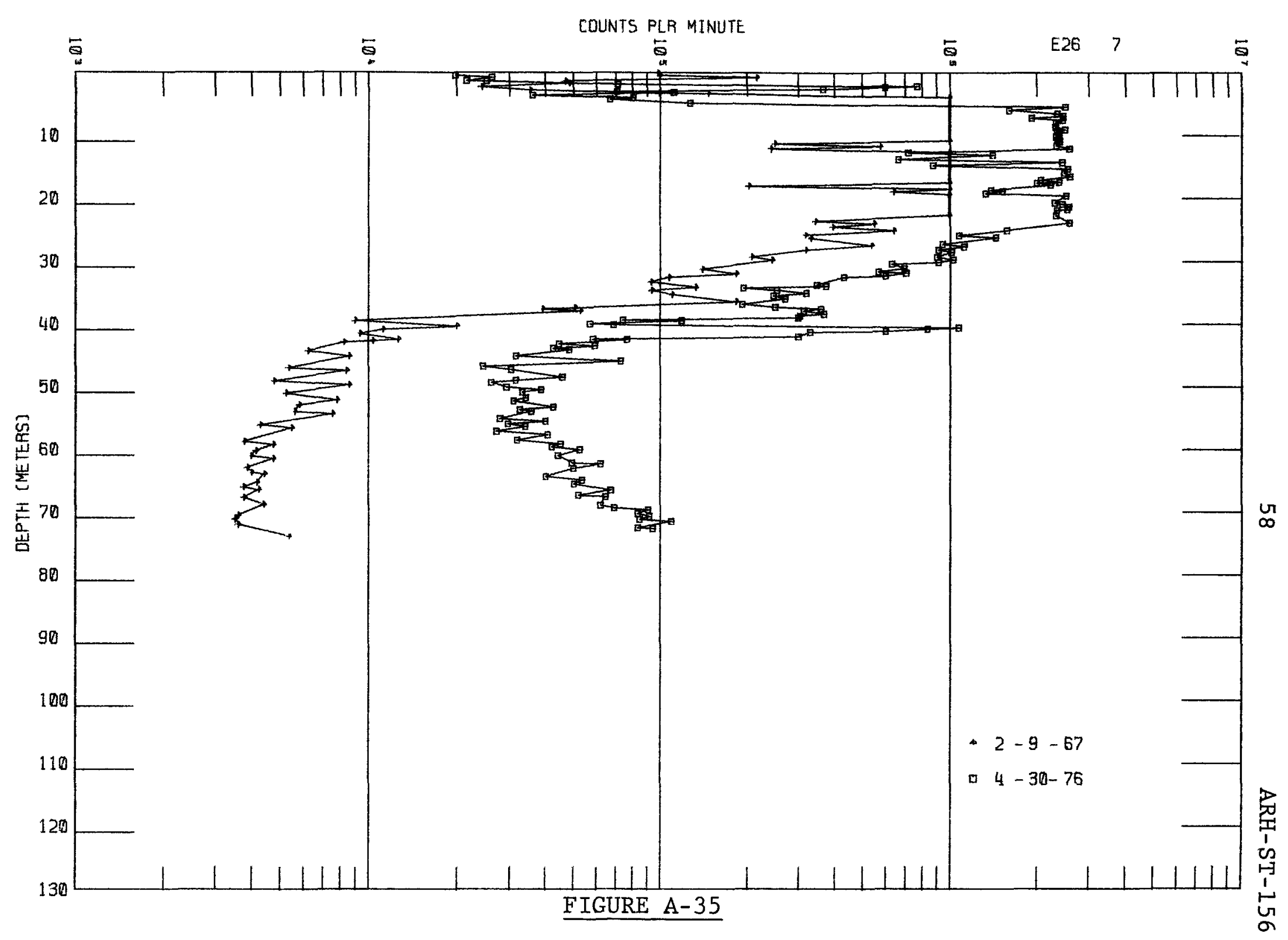

WELL E26-7 SCINTILIATION PROBE PROFILES 

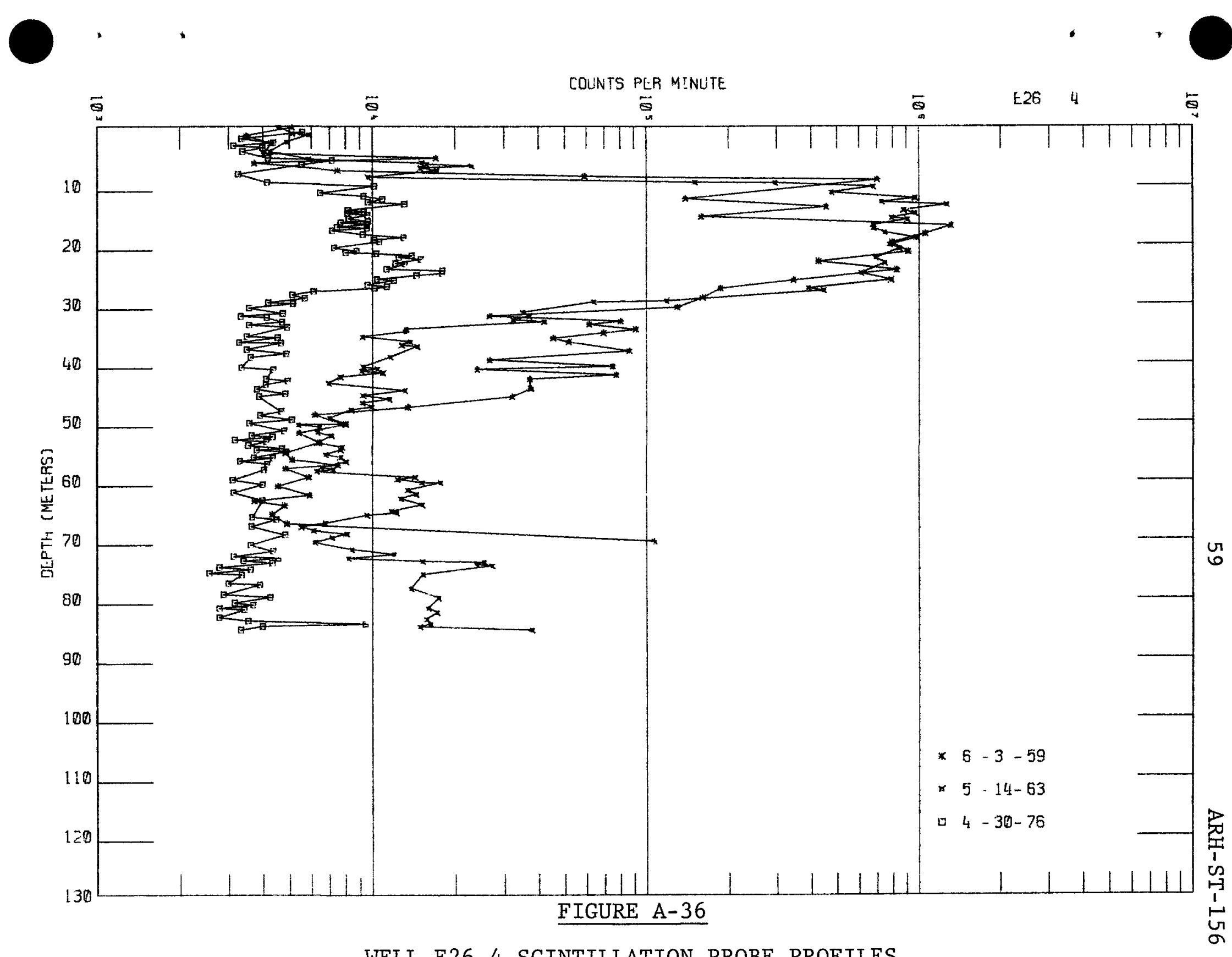

WELL E26-4 SCINTILLATION PROBE PROFILES 


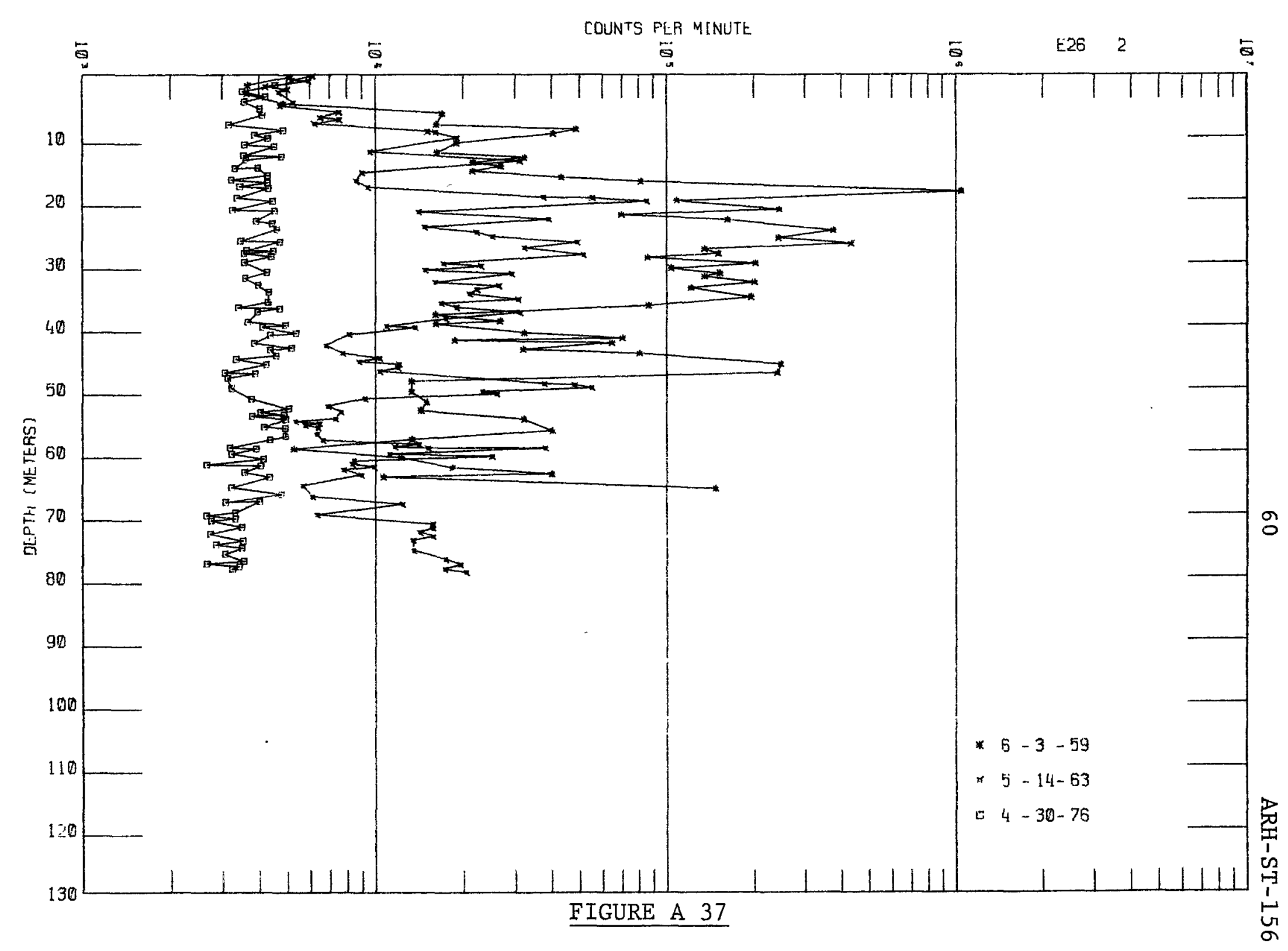

WELL E26-2 SCINTILLATION PROBE PROFILES 


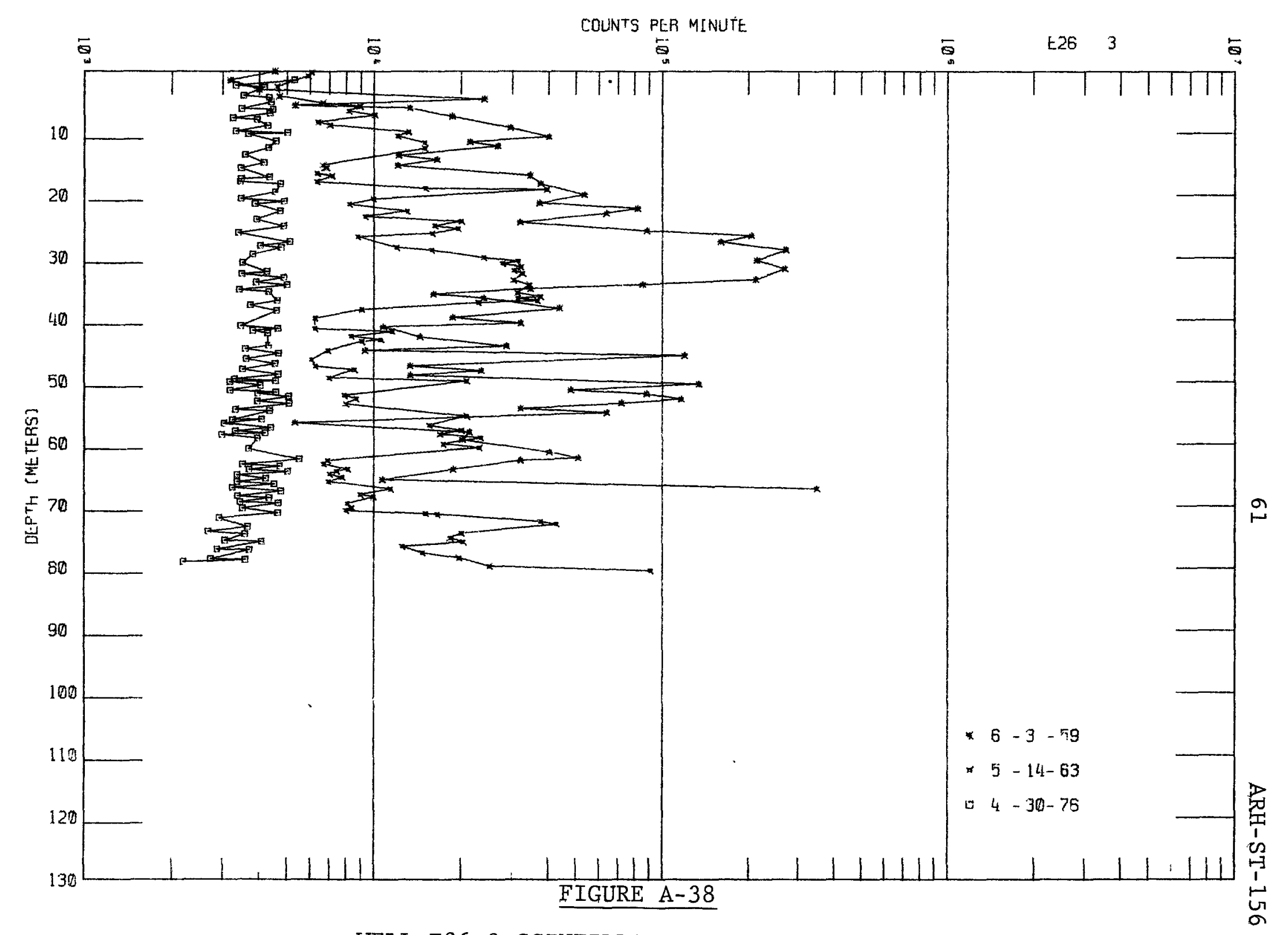

WELL E26-3 SCINTILLATION PROBE PROFILES 
Description of Waste: Sump waste from 293-A Building, laboratory cell drainage from 202-A Building and 291-A-1 stack drainage.

Service Dates: 1965 to 1970

Waste Volume: $2.32 \times 10^{7}$ liters

Waste Inventory:

\begin{tabular}{ccc} 
& Total & Decayed Thru June 1976 \\
\cline { 2 - 2 } $\mathrm{Pu}, \mathrm{g}$ & $9.65 \times 10^{7}$ & $9.65 \times 10^{7}$ \\
$\mathrm{Beta}, \mathrm{Ci}$ & $2.68 \times 10^{3}$ & $1.89 \times 10^{2}$ \\
${ }^{90} \mathrm{Sr}, \mathrm{Ci}$ & $4.13 \times 10^{7}$ & $3.47 \times 10^{7}$ \\
${ }^{106} \mathrm{Ru}, \mathrm{Ci}$ & $6.32 \times 10^{7}$ & $2.58 \times 10^{-1}$ \\
${ }^{137} \mathrm{Cs}, \mathrm{Ci}$ & $5.26 \times 10^{7}$ & $4.49 \times 10^{7}$ \\
${ }^{60} \mathrm{Co}, \mathrm{Ci}$ & $<2.67 \times 10^{0}$ & $<1.05 \times 10^{0}$ \\
U, kg & $6.80 \times 10^{1}$ & $6.80 \times 10^{1}$ \\
$233_{\mathrm{U}, \mathrm{g}}$ & $1.68 \times 10^{2}$ & $1.68 \times 10^{2}$
\end{tabular}

Evaluation of Scintillation Probe Profiles:

We11s E17-2 and E17-3 monitor the 216-A-27 crib (figures A-1 and $A-4)$. In well E17-2 radioactive contaminants are detected at the base of the crib ( 4.6 meters below the ground surface) increasing to maximum radiation intensity 4.6 meters below the crib bottom (figure A-38). The radioactive contaminants detected in We11 E17-3 are found between 24.4 and 41.1 meters below the ground surface (figure A-39). This activity is attributed to waste discharged to the $216-\mathrm{A}-36 \mathrm{~A}$ crib based (1) on the proximity of the 216-A-36A crib to the 216-A-27 crib (2) on the total beta discharged to the two cribs $\left(1.47 \times 10^{5}\right.$ curies to the $216-\mathrm{A}-36 \mathrm{~A}$ crib and $1.59 \times 10^{3}$ curies to the $\left.216-\mathrm{A}-27 \mathrm{crib}\right)$ and (3) on the estimated spatial distribution of radionuclides in the sediments beneath the two cribs from available well data. 
The radionuclides discharged to the $216-\mathrm{A}-27 \mathrm{crib}$ have not been effectively dispersed over the length of the crib. The west end of the crib received very little, if any, contaminated effluent as evidenced by the low radiation intensity in the profile immediately below the crib in Well E17-3. Most of the activity appears to have percolated into the ground near the head end of the crib.

The radioactive contaminants detected by the scintillation probe logging of Well E17-2 indicates that more activity was discharged to the ground via the 216-A-27 crib than the estimated 1590 curies of total beta. Even considering a point discharge at the head end of the crib the estimated total beta inventory is probably low.

Well E17-2 profiles from 1968 to 1976 show minor decay of radionuclides indicating much of the activity is from long-lived gamma-emitting radionucides. On the basis of Well E17-2 minor redistribution of radionuclides within the zone at contamination has been detected in the sediments beneath the 216-A-27 crib. These data indicate breakthrough to groundwater has not occurred at this site. 


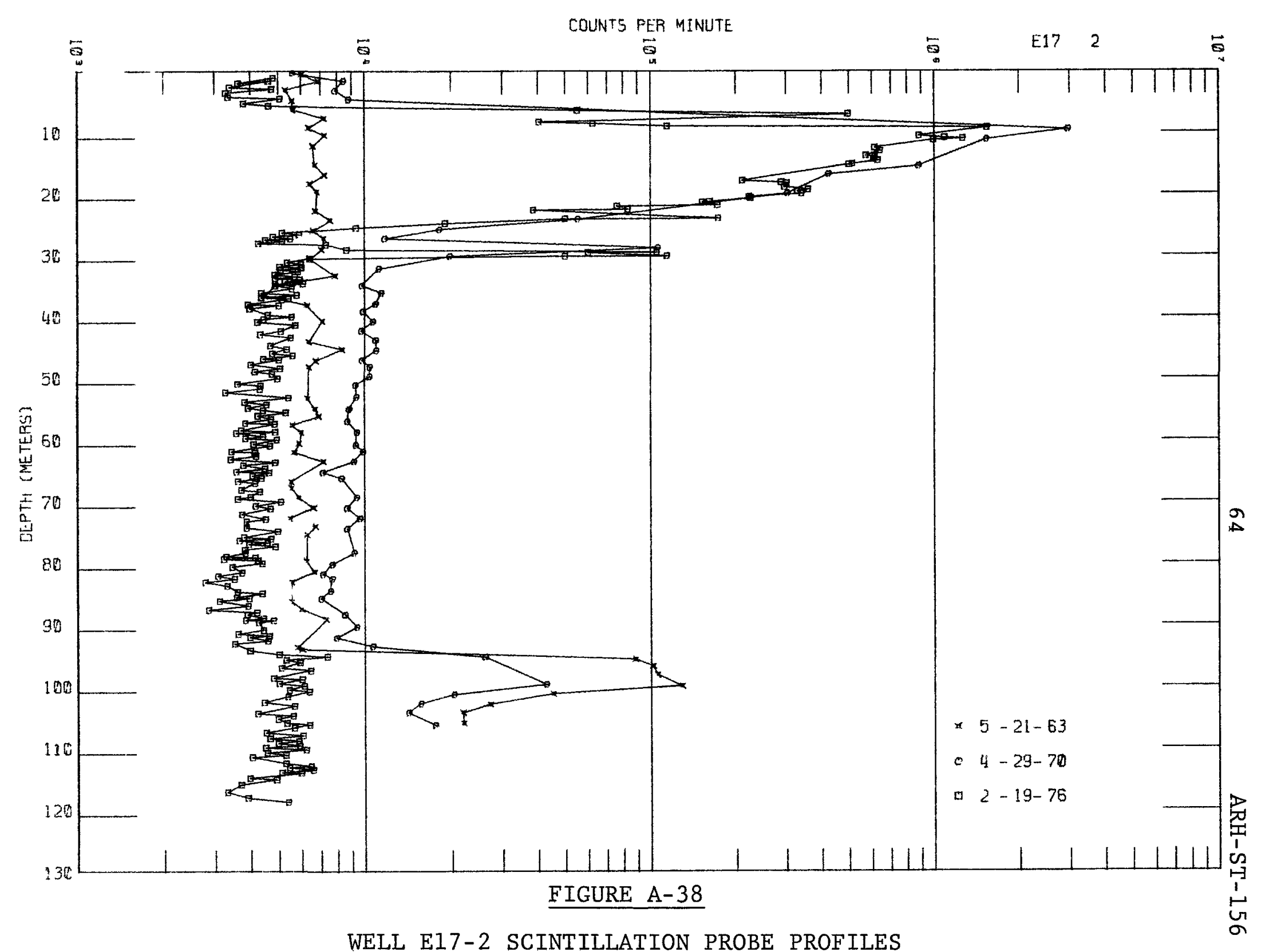




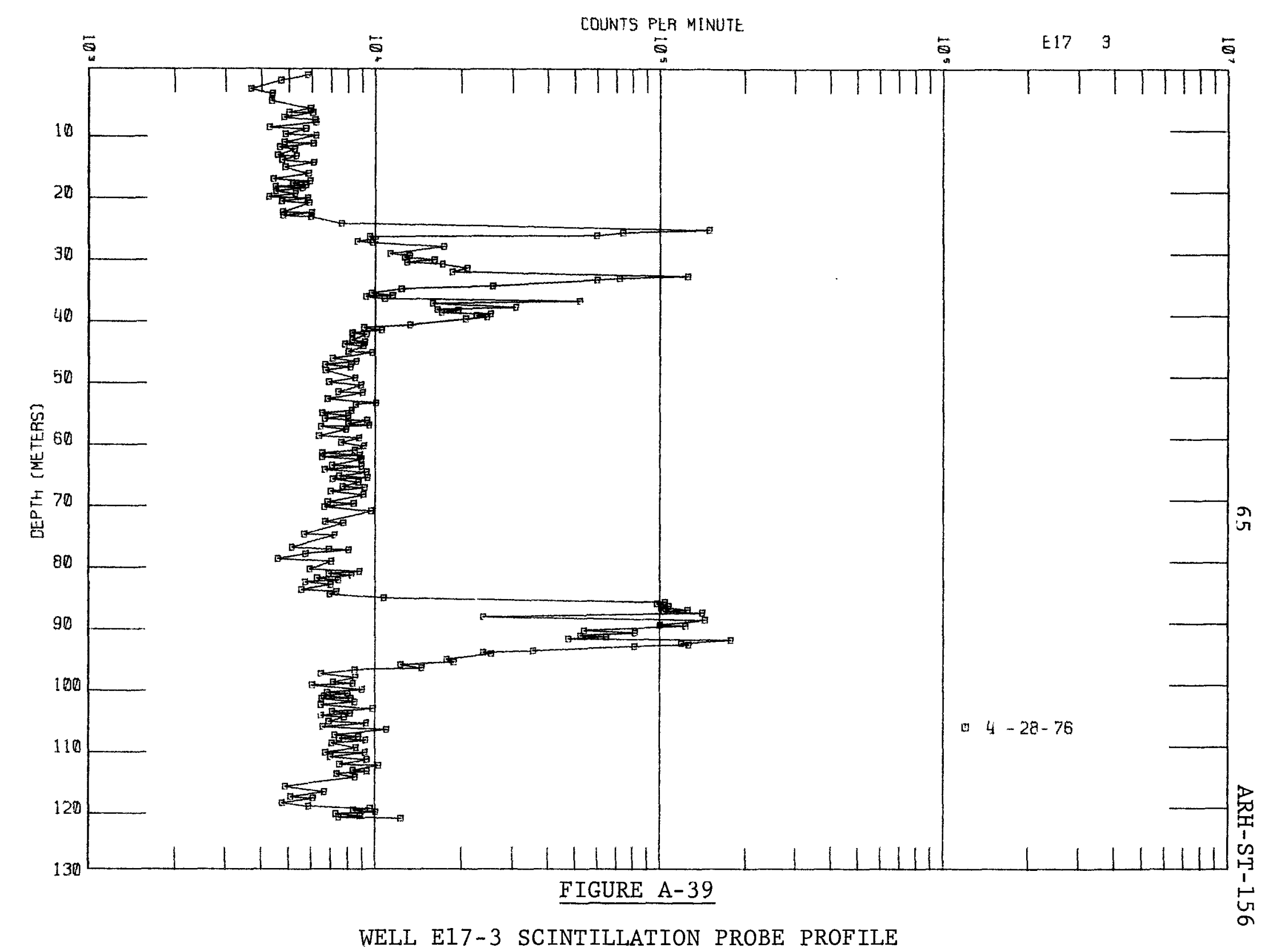




\section{6-A-30 Crib}

Description of Waste: Liquid waste from 202-A; steam condensate, equip ment disposal tunnel floor drainage, water filled door drainage and slug storage basin overflow.

Service Dates: 1961 to 1973 and 1976

Waste Volume: $3.60 \times 10^{9}$ liters

Waste Inventory:

\begin{tabular}{ccc} 
& Total & Decayed Thru June 1976 \\
\cline { 2 - 2 }, $\mathrm{g}$ & $<7.22 \times 10^{1}$ & $<7.22 \times 10^{1}$ \\
$\mathrm{Beta}, \mathrm{Ci}$ & $5.44 \times 10^{3}$ & $6.23 \times 10^{2}$ \\
${ }^{90} \mathrm{Sr}, \mathrm{Ci}$ & $1.87 \times 10^{2}$ & $1.44 \times 10^{2}$ \\
${ }^{106} \mathrm{Ru}, \mathrm{Ci}$ & $1.96 \times 10^{2}$ & $1.43 \times 10^{0}$ \\
${ }^{137} \mathrm{Cs}, \mathrm{Ci}$ & $2.20 \times 10^{2}$ & $1.61 \times 10^{2}$ \\
${ }^{60} \mathrm{Co}, \mathrm{Ci}$ & $1.66 \times 10^{1}$ & $3.05 \times 10^{0}$ \\
$\mathrm{U}, \mathrm{Kg}$ & $<4.13 \times 10^{1}$ & $<4.13 \times 10^{7}$ \\
${ }^{233_{\mathrm{U}}, \mathrm{g}}$ & $<7.48 \times 10^{0}$ & $<7.48 \times 10^{0}$
\end{tabular}

\section{Evaluation of Scintillation Probe Profiles:}

We11s E16-2, E25-11 and E25-12 monitor the 216-A-30 crib (figures $A-1$ and $A-40)$. Low-level radioactive contaminants were detected in we11s E25-11 and E25-12 in 1963 (figures A-41, A-42, and A-43). In 1976 the scintillation probe profiles show minor activity in al1 three wells. The decrease in radiation intensity is due to decay of shortlived radionuclides disposed to the ground from the $216-\mathrm{A}-30$ crib. On the basis of the scintillation probe profiles no migration of radionuclides in the sediments beneath the crib have been detected. These data indicate breakthrough to the groundwater has not occurred at this site. 


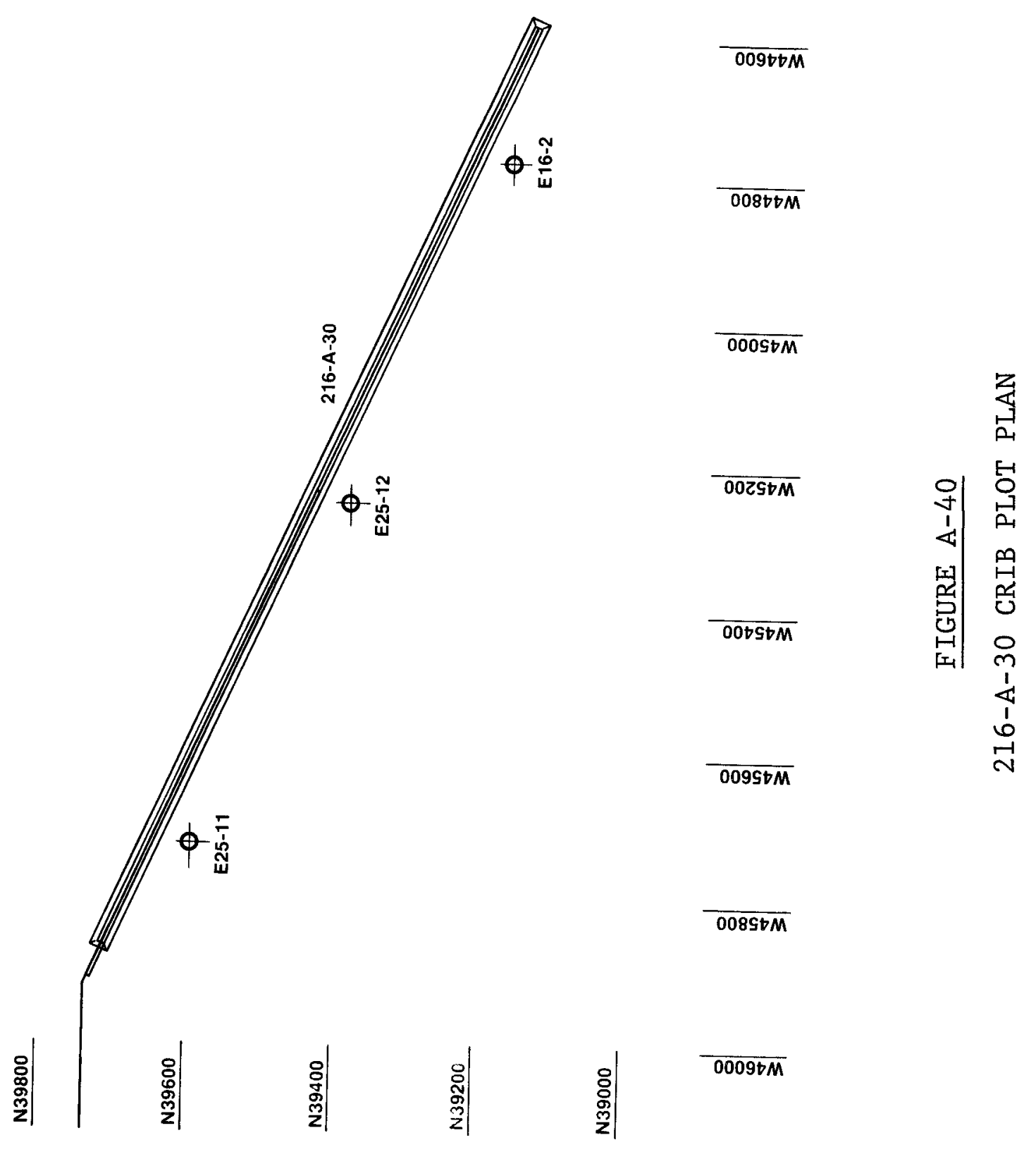




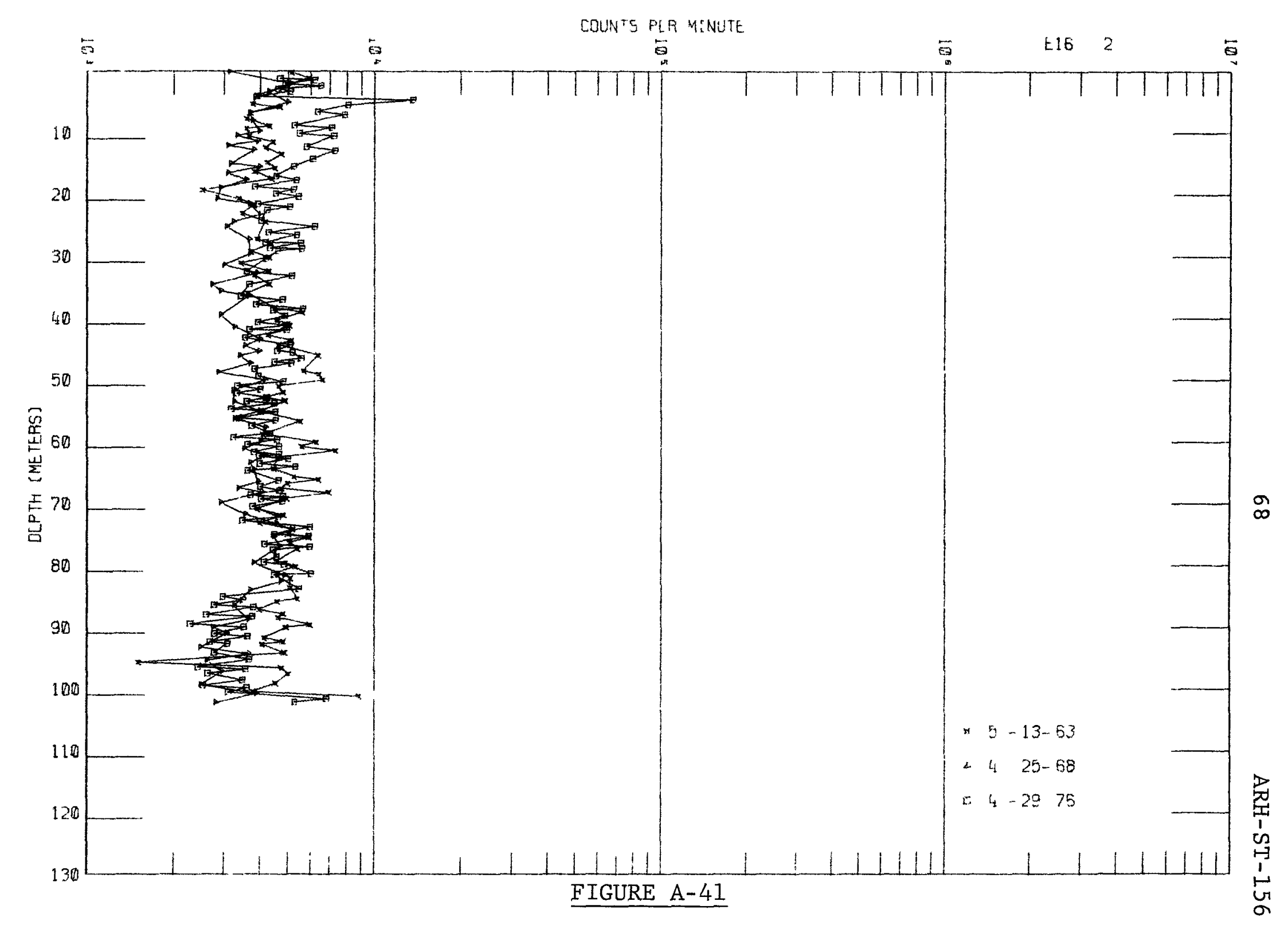

WELL E16-2 SCINTILLATION PROBE PROFILES 
0 .

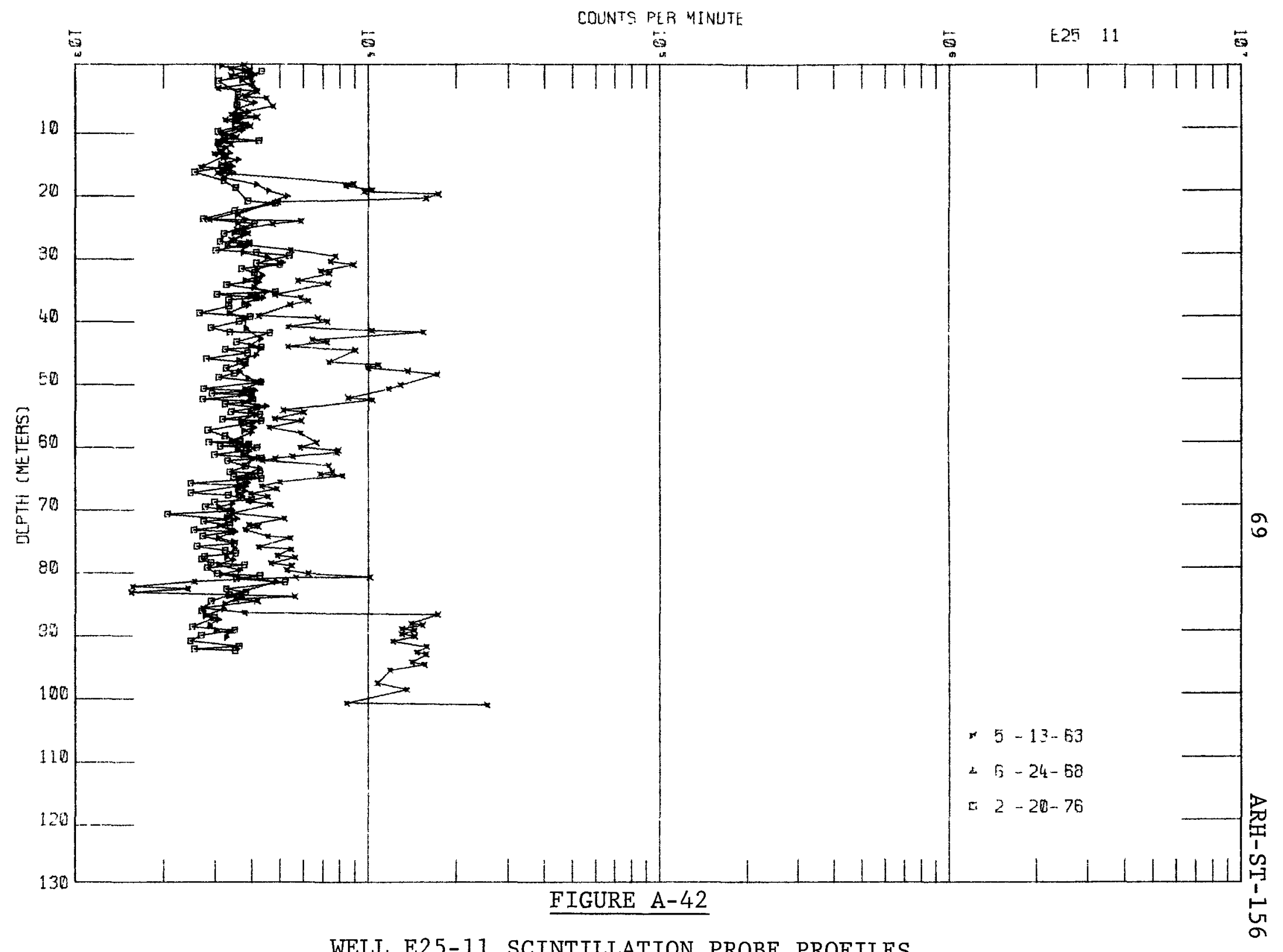

WELL E25-11 SCINTILLATION PROBE PROFILES 


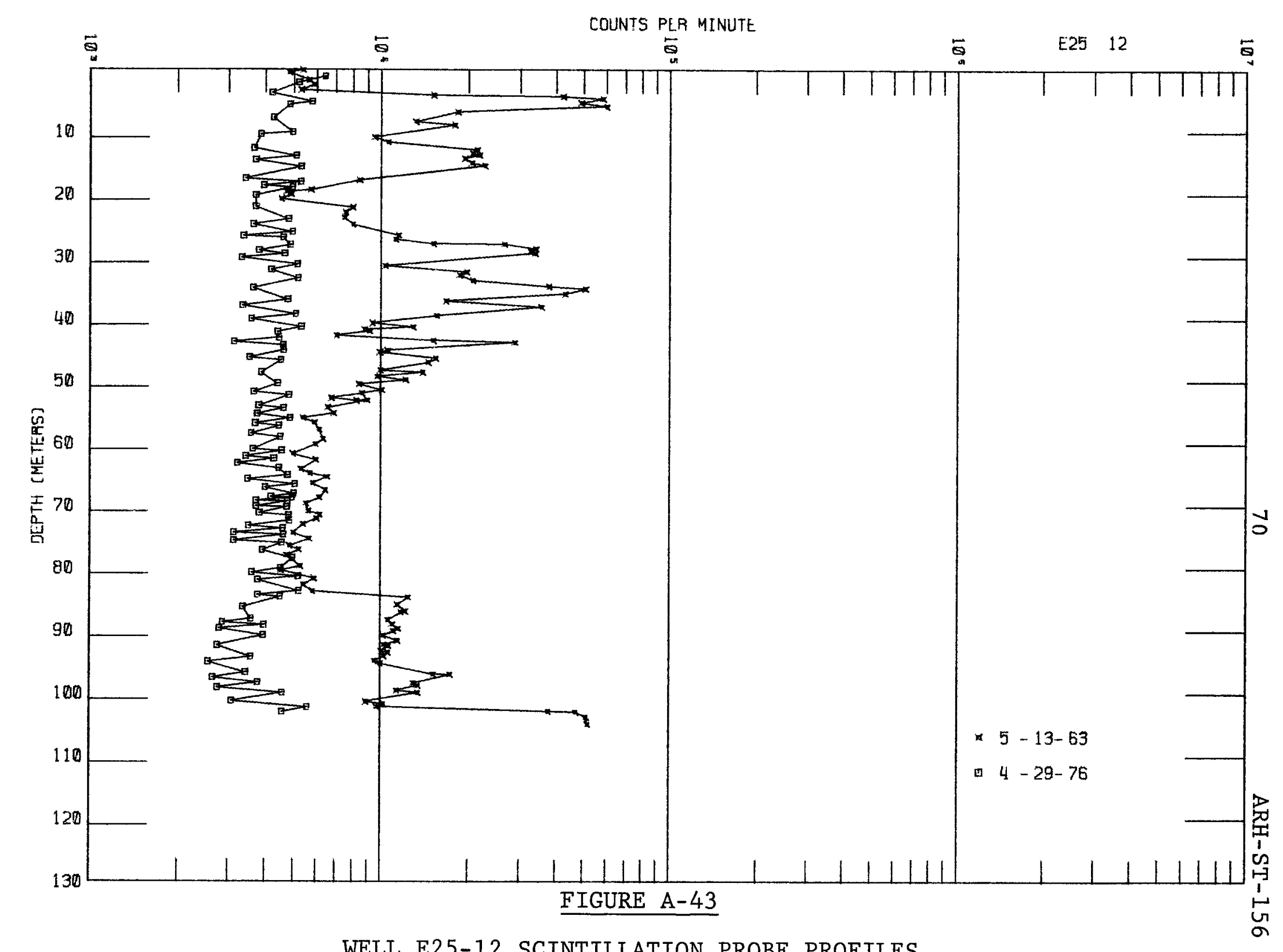

WELL E25-12 SCINTILLATION PROBE PROFILES 


\section{6-A-31 Specific Retention Crib}

Description of Waste: Organic waste from 202-A.

Service Dates: 1964 and 1966

Waste Volume: $1.0 \times 10^{4}$ 1iters

Waste Inventory:

\begin{tabular}{|c|c|c|}
\hline & Total & Decayed Thru June 1976 \\
\hline $\mathrm{Pu}, \mathrm{g}$ & $9.00 \times 10^{0}$ & $9.00 \times 10^{0}$ \\
\hline Beta, Ci & $2.00 \times 10^{5}$ & $3.08 \times 10^{2}$ \\
\hline${ }^{90} \mathrm{Sr}, \mathrm{Ci}$ & $2.00 \times 10^{0}$ & $1.49 \times 10^{0}$ \\
\hline${ }^{106} \mathrm{Ru}, \mathrm{Ci}$ & $9.50 \times 10^{4}$ & $2.42 \times 10^{1}$ \\
\hline${ }^{137} \mathrm{Co}, \mathrm{Ci}$ & $1.50 \times 10^{2}$ & $1.14 \times 10^{2}$ \\
\hline${ }^{60} \mathrm{Co}, \mathrm{Ci}$ & $1.00 \times 10^{-1}$ & $2.06 \times 10^{-2}$ \\
\hline $\mathrm{U}, \mathrm{kg}$ & $2.05 \times 10^{7}$ & $2.05 \times 10^{7}$ \\
\hline
\end{tabular}

Evaluation of Scintillation Probe Data:

The 216-A-31 crib is monitored by We11 E24-9 which is located 21 meters south of the crib (figures $A-1$ and $A-4$ ). No radioactive contaminants have been detected in the sediments above the water table at this well (figure A-44). The waste inventory and waste volume indicate breakthrough to the groundwater has not occurred at this site. 


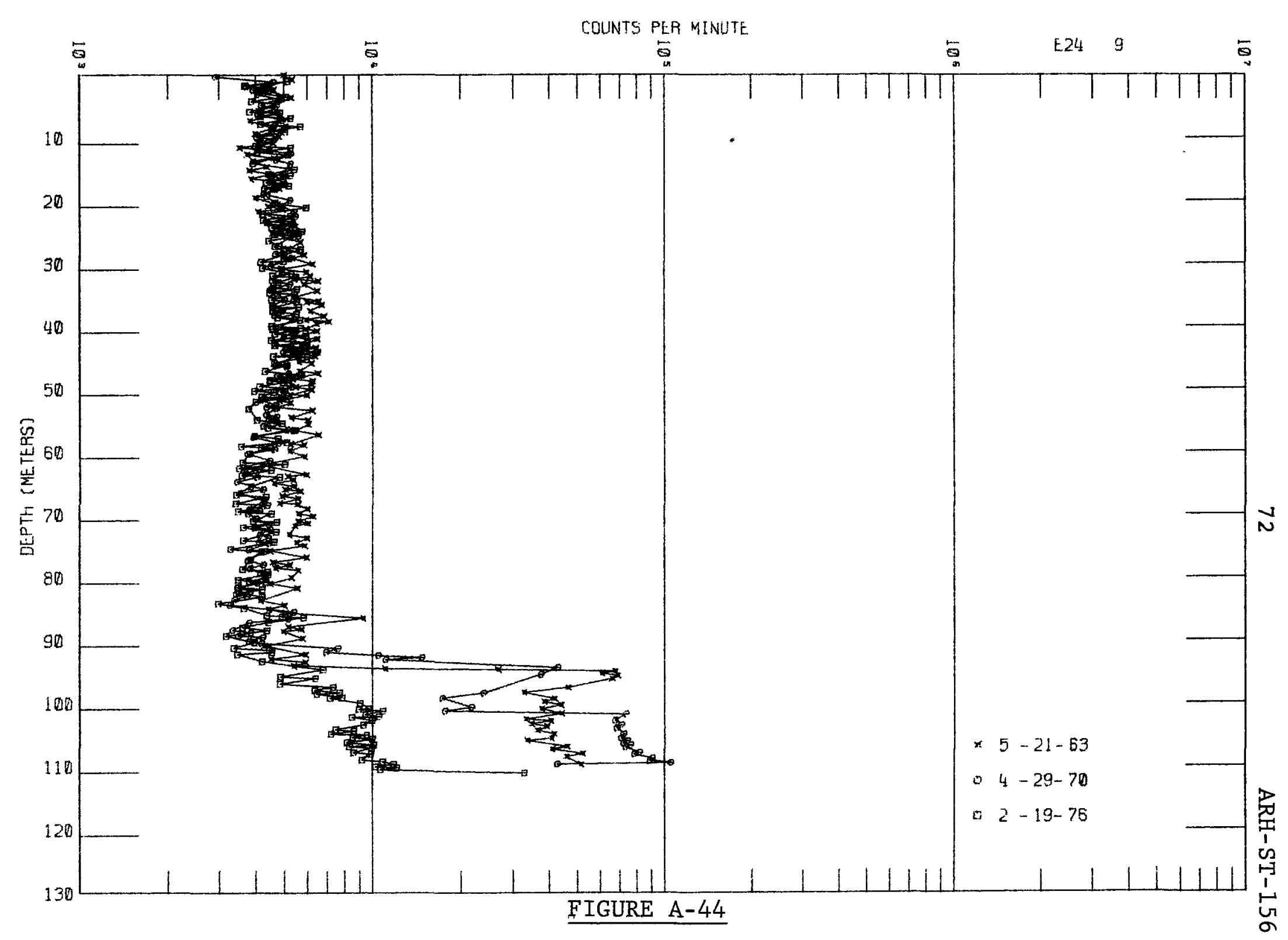

WELL E24-9 SCINTILLATION PROBE PROFILES 


\section{6-A-36A Specific Retention Crib}

Description of Waste: Ammonia scrubber waste from 202-A.

Service Dates: 1965 to 1966

Waste Volume: $1.07 \times 10^{6}$ liters

Waste Inventory:

Pu, g
Beta, Ci
${ }^{90} \mathrm{Sr}, \mathrm{Ci}$
${ }^{106} \mathrm{Ru}, \mathrm{Ci}$
${ }^{137} \mathrm{Cs}, \mathrm{Ci}$
${ }^{60} \mathrm{Co}, \mathrm{Ci}$
U, $\mathrm{kg}$ $\frac{\text { Total }}{8.00 \times 10^{1}}$

$1.47 \times 10^{5}$

$1.80 \times 10^{3}$

$3.00 \times 10^{3}$

$1.50 \times 10^{3}$

$1.00 \times 10^{1}$

$1.45 \times 10^{2}$
Decayed Thru June 1976

$8.00 \times 10^{1}$

$6.01 \times 10^{3}$

$1.41 \times 10^{3}$

$3.05 \times 10^{0}$

$1.19 \times 10^{3}$

$2.65 \times 10^{0}$

$1.45 \times 10^{2}$

Evaluation of Scintillation Probe Profiles:

Wells E17-4, E17-9 and E17-10 monitor the 216-A-36A crib (figures A-1 and $A-45)$. In 1976 radioactive contaminants in Well E17-4 located near the head of the $216-\mathrm{A}-36 \mathrm{~A}$ crib are detected from 18.3 meters below the ground surface to the water table (figure $A-46$ ). Well E17-9 radioactive contaminants are detected from 8.2 meters below the ground surface and the water table (figure A-47). In the lower portion of the Well E17-9 profile near background levels of radiation intensity are detected. Background radiation intensity is detected in We11 E17-10 (figure A-48).

On the basis of the scintillation probe profiles minor soil drainage has occurred in We11 E17-4 between 1968 and 1970. The radiation intensity increased between 1968, two years after waste disposal to the crib was terminated and 1970. By 1976 the radiation intensity has decreased by radionuclide decay. These data indicate breakthrough to the groundwater could have occurred at this site. 


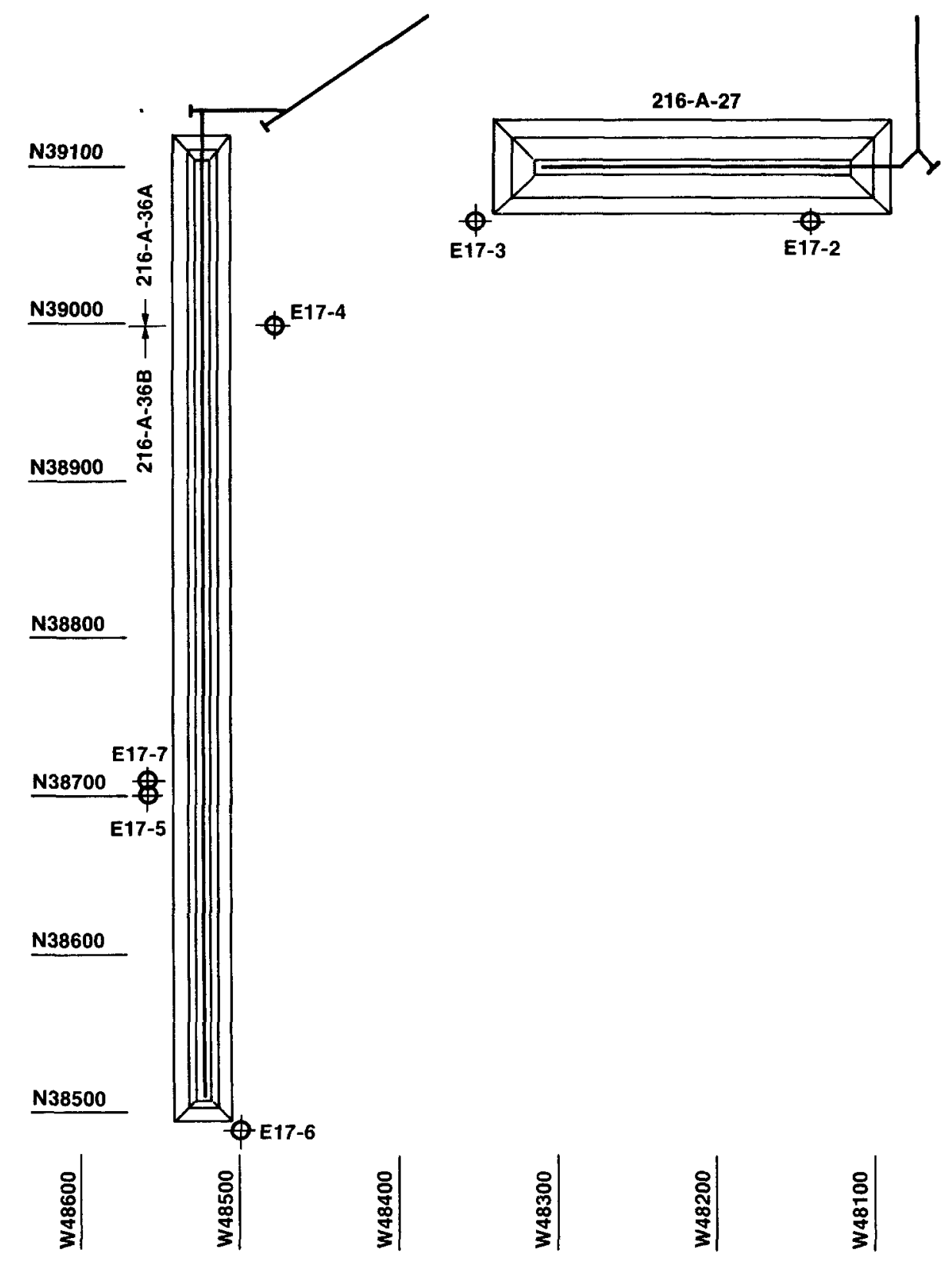

FIGURE A-45

216-A-27 AND 216-A-36A AND B CRIB PLOT PLANS 
$\bigoplus \cdot$

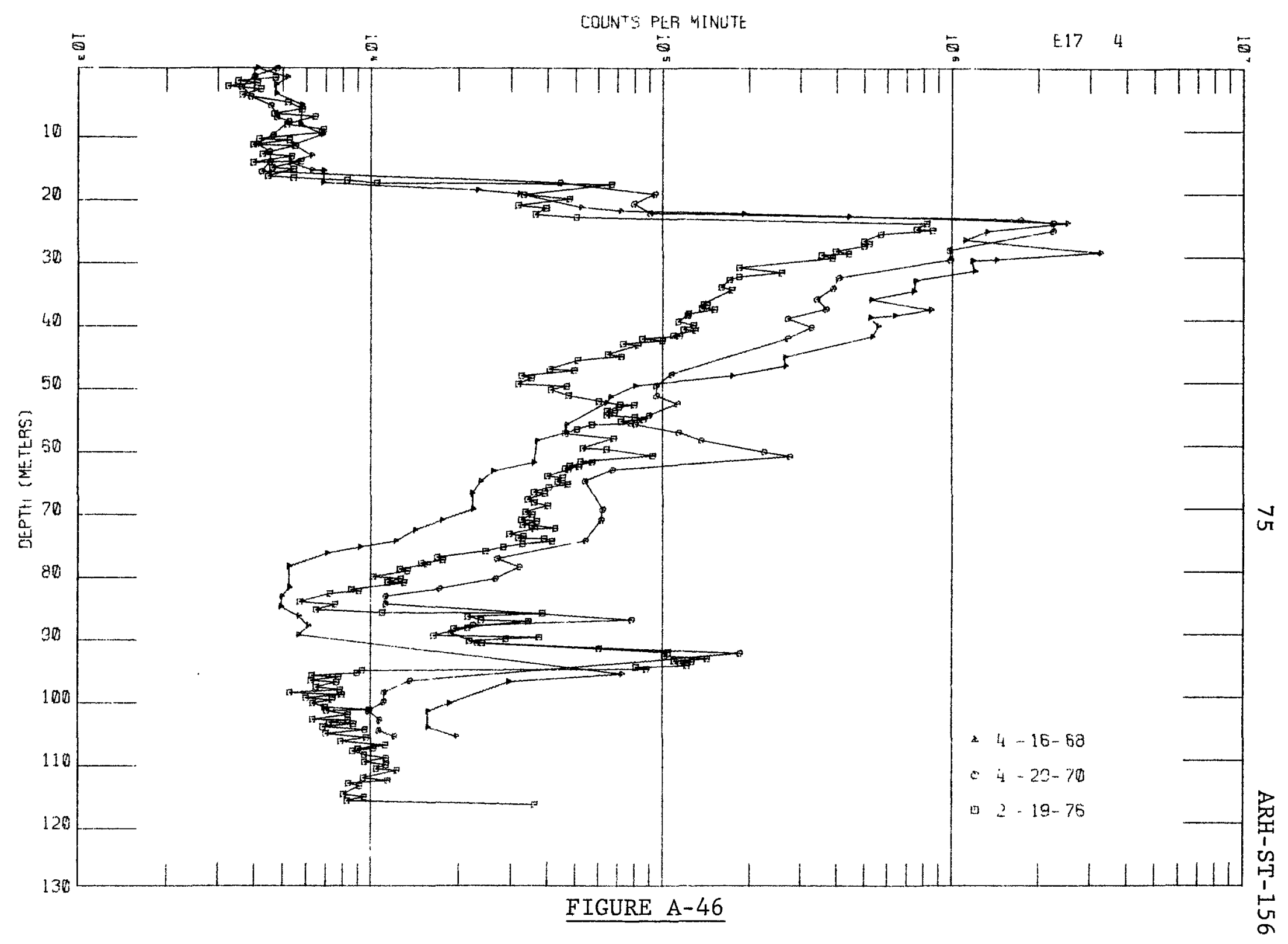

WELL E17-4 SCINTILLATION PROBE PROFILES 


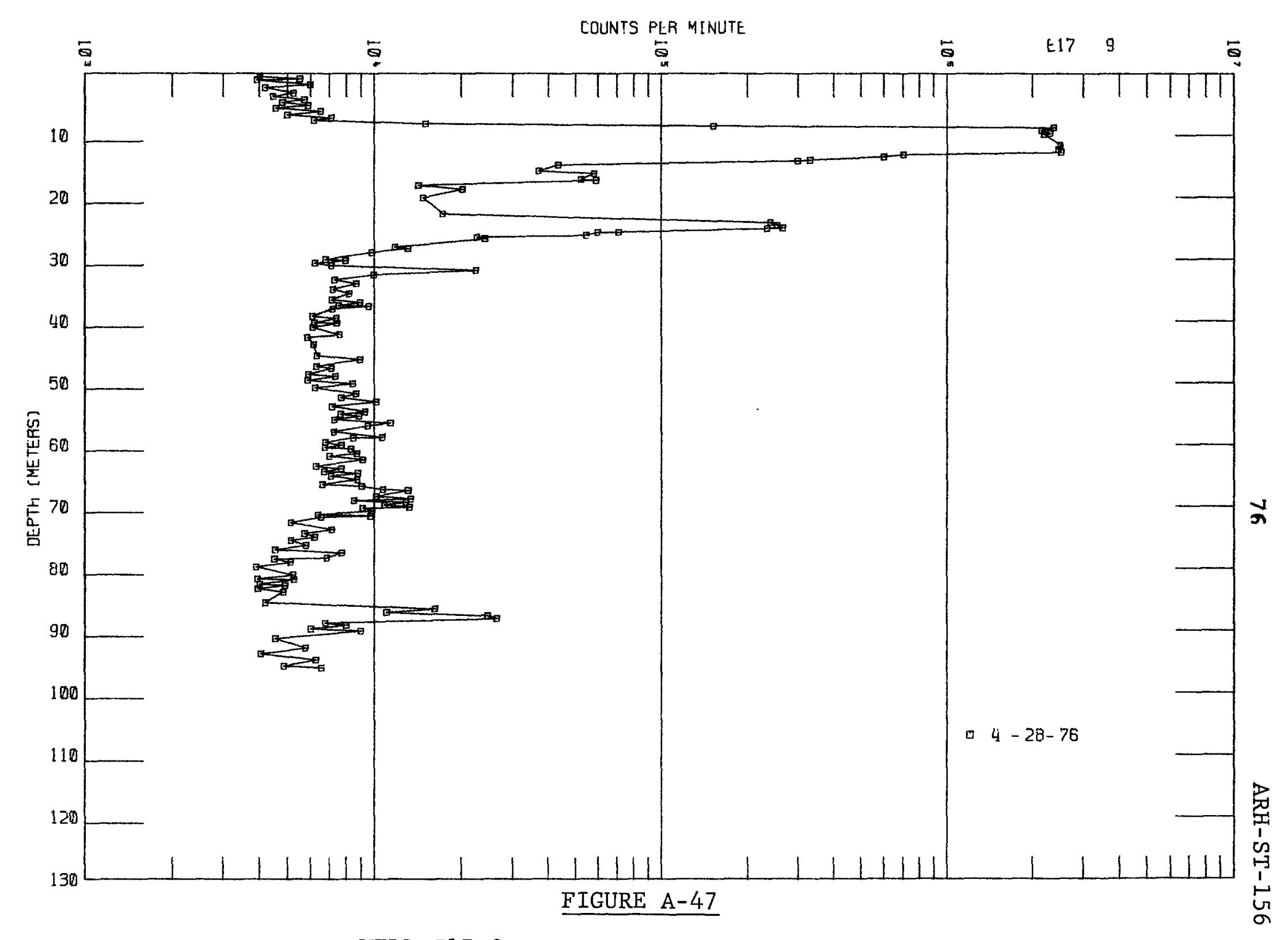

WELL E17-9 SCINTILLATION PROBE PROFILES 


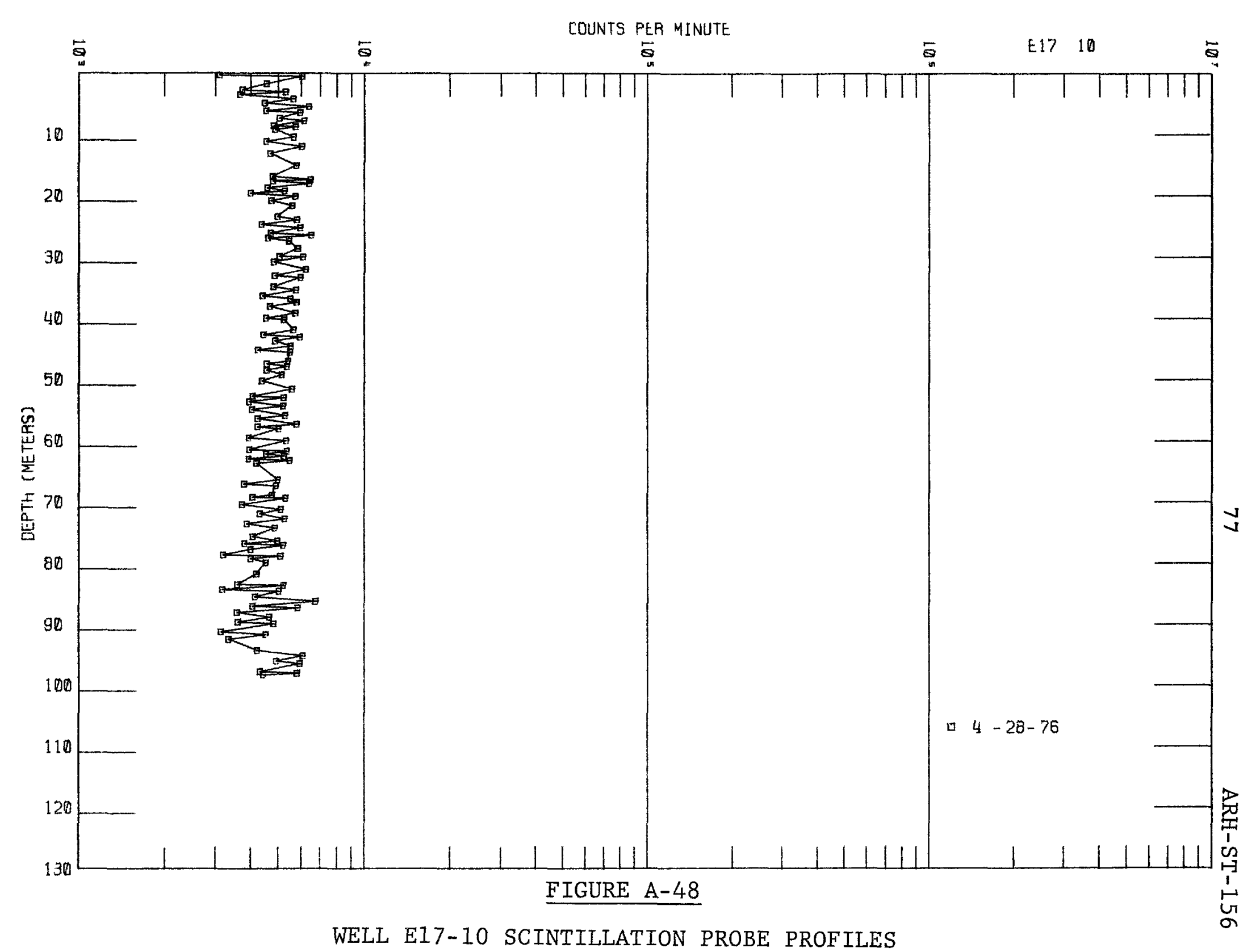




\section{$216-A-36 B$ Crib}

Description of Waste: Ammonia scrubber waste from the 202-A Building.

Service Dates: 1966 to 1972

Waste Volume: $9.40 \times 10^{7}$ liters

Waste Inventory:

\begin{tabular}{crc} 
& \multicolumn{1}{c}{ Total } & Decayed Thru June 1976 \\
\cline { 2 - 3 } $\mathrm{Pu}, \mathrm{g}$ & $<1.77 \times 10^{2}$ & $<1.77 \times 10^{2}$ \\
${ }^{\mathrm{Beta}}, \mathrm{Ci}$ & $4.75 \times 10^{4}$ & $2.79 \times 10^{3}$ \\
${ }^{90} \mathrm{Sr}, \mathrm{Ci}$ & $5.46 \times 10^{2}$ & $4.67 \times 10^{2}$ \\
${ }^{106} \mathrm{Ru}, \mathrm{Ci}$ & $6.53 \times 10^{3}$ & $1.82 \times 10^{2}$ \\
${ }^{137} \mathrm{Cs}, \mathrm{Ci}$ & $<5.56 \times 10^{2}$ & $<4.84 \times 10^{2}$ \\
${ }^{60} \mathrm{Co}, \mathrm{Ci}$ & $<5.14 \times 10^{1}$ & $<2.39 \times 10^{1}$ \\
U, kg & $1.19 \times 10^{2}$ & $1.19 \times 10^{2}$ \\
$233_{\text {U, g }}$ & $2.56 \times 10^{1}$ & $2.56 \times 10^{1}$
\end{tabular}

Evaluation of Scintillation Probe Profiles:

Wells E17-5, E17-6 and E17-7 monitor the 216-A-36B crib (figures $A-1$ and A-45). Radioactive contaminants are detected 1 meter above the distributor pipe (7.3 meters below the ground surface) in wells El7-5 and E17-7 (figures $A-49$ and A-50). The radiation intensity in the two major zones of contamination increased rapidly during crib operations. Four years after disposal to the crib was terminated the radiation intensity has continued to increase, indicating the system has not equilibrated. The radiation intensity in Well E17-6 has remained at background (figure A-51).

The radionuclides discharged to the $216-\mathrm{A}-36 \mathrm{~B}$ crib have not been effectively dispersed over the length of the crib. The south end received very little, if any, contaminated effluent as evidenced by the absence of radioactive contaminants in the scintillation probe profiles of Well E17-6. Most radioactive effluent appears to have percolated into the ground in the upper portion of the crib. 
On the basis of wells El7-5 and E17-7 no measurable downward migration of radionuclides has occurred in the sediments beneath the crib after discharge of waste to the crib was terminated. Lateral movement of radioactive contaminants has been detected in these wells. These data indicate breakthrough to groundwater has not occurred at this site from radionuclides discharged to the $216-\mathrm{A}-36 \mathrm{~B}$ crib. 


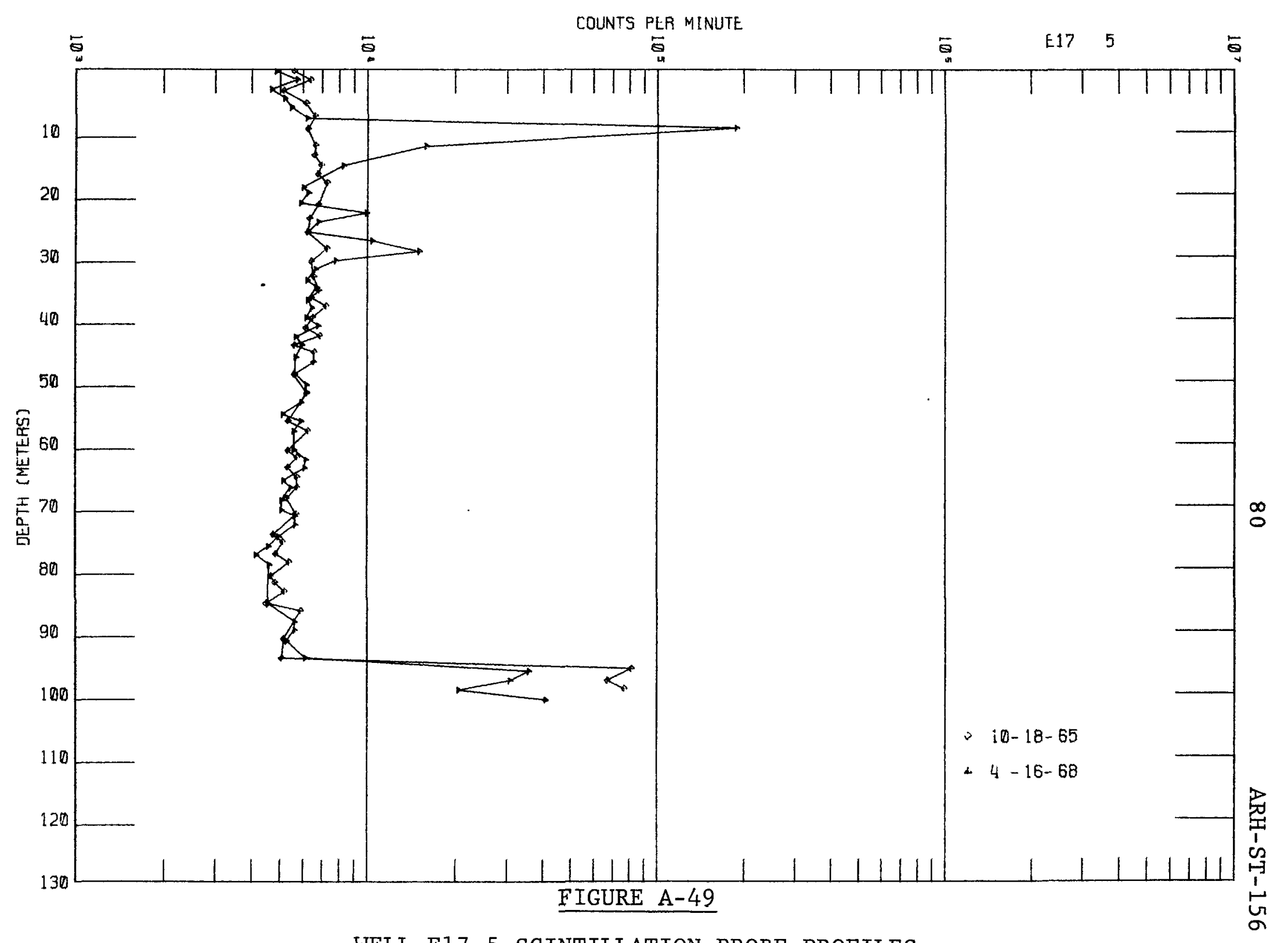

WELL E17-5 SCINTILLATION PROBE PROFILES 


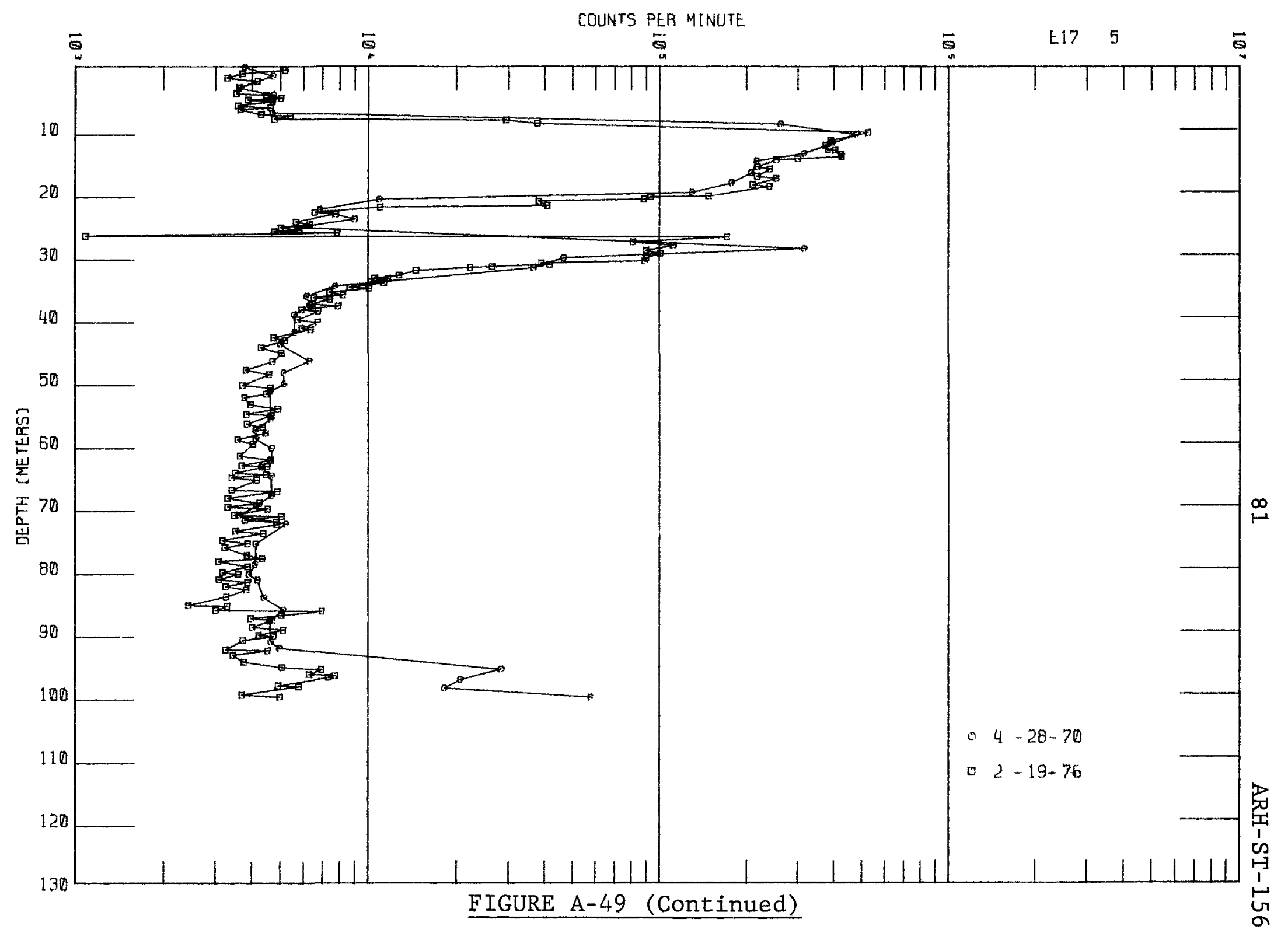

WELL E17-5 SCINTILLATION PROBE PROFILES 


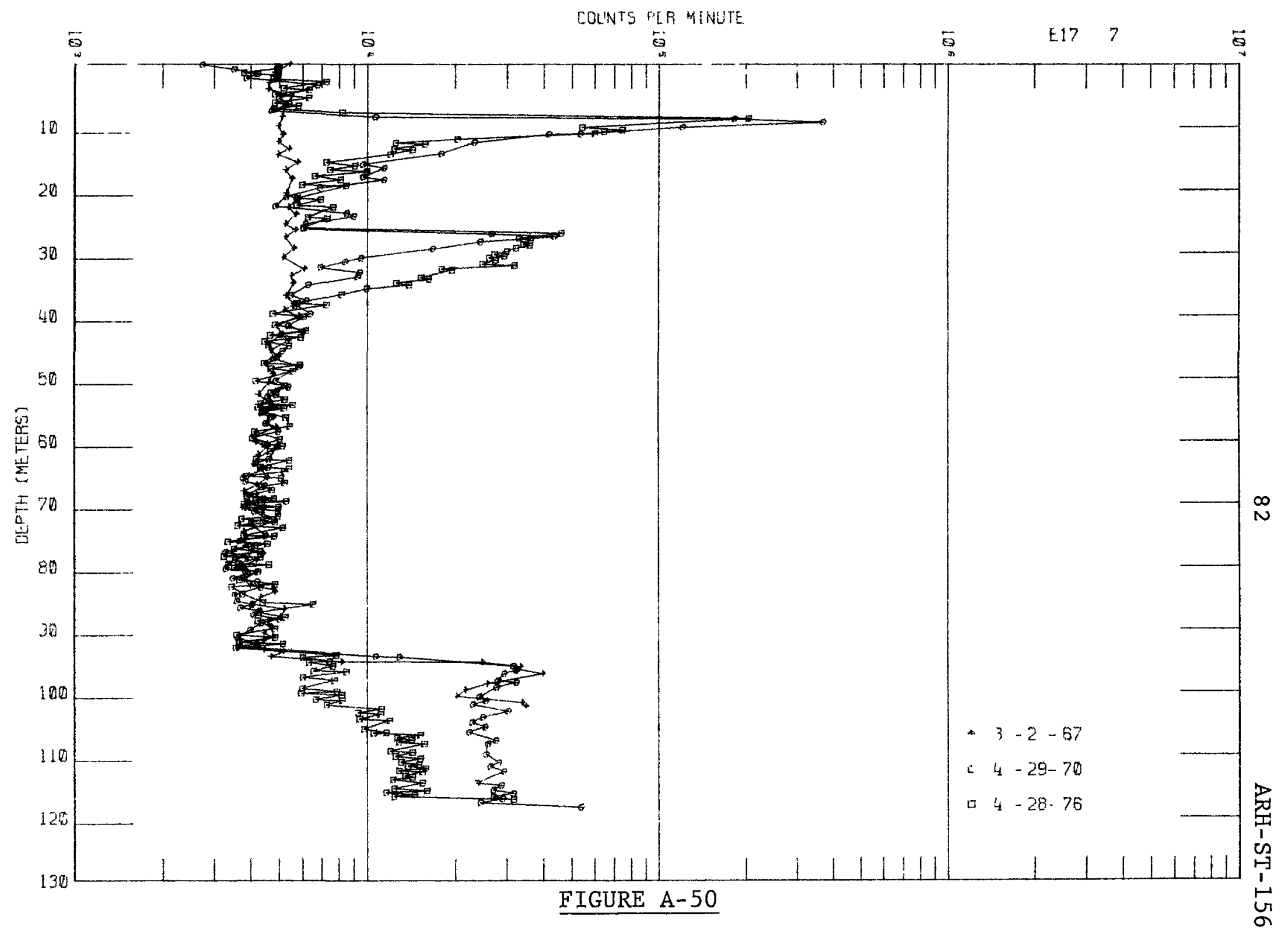

WELL E17-7 SCINTILLATION PROBE PROFILES 
$\longrightarrow+$

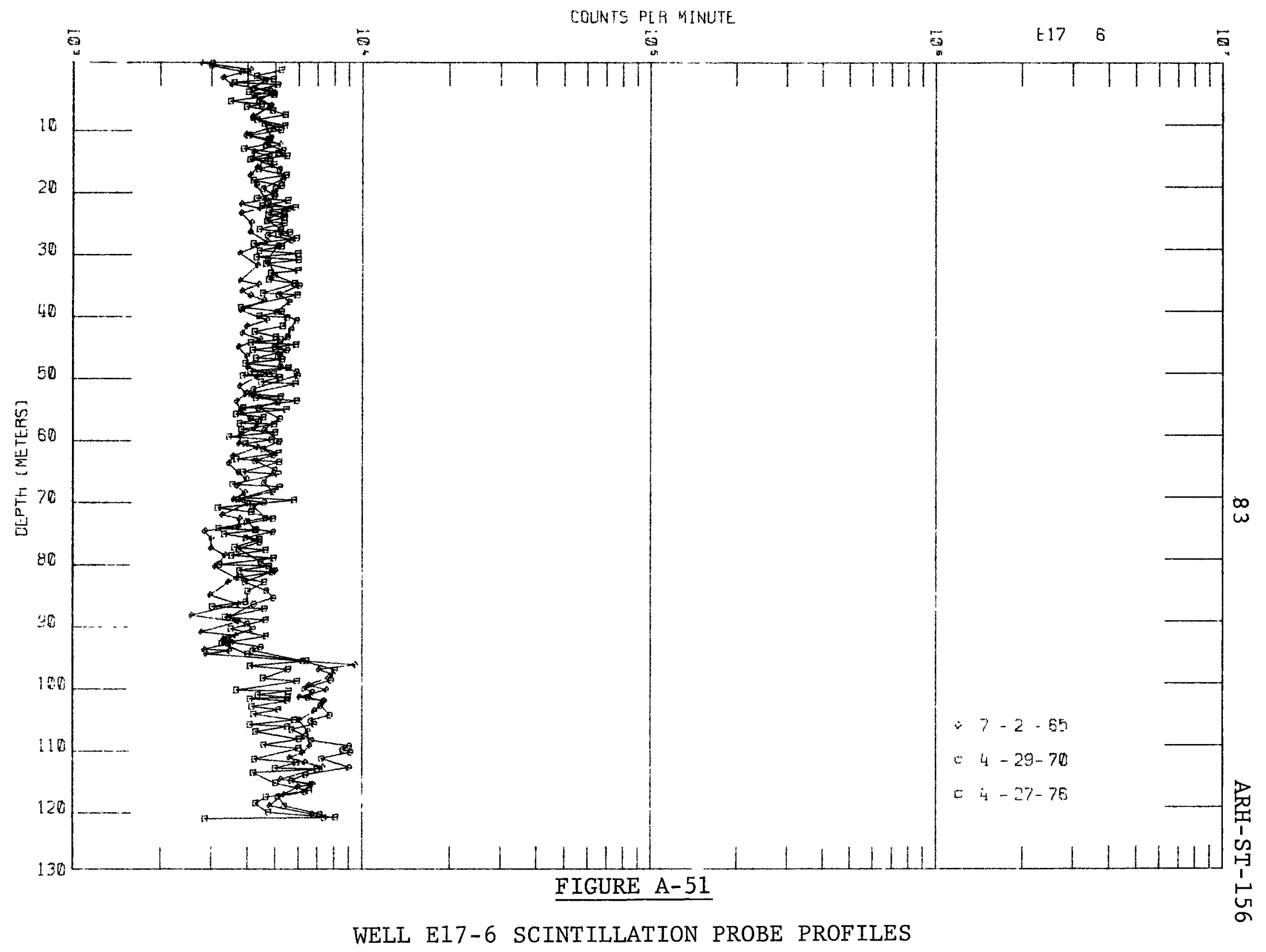




\section{6-A-38 Crib}

Description of Waste: Never Used.

Service Dates: Not applicable.

Waste Volume: Not applicable.

Waste Inventory:

Not applicable.

Evaluation of Scintillation Probe Profiles:

Wells E17-8 and E24-11 monitor the 216-A-38 crib (figures A-1 and A-52). Radiation levels above background is detected 30 meters below the ground surface (figures $A-53$ and A-54). This activity is probably associated with lateral migration of radionuclides discharge to the ground at the 216-A-10 crib immediately to the east of the 216-A-3B crib. 


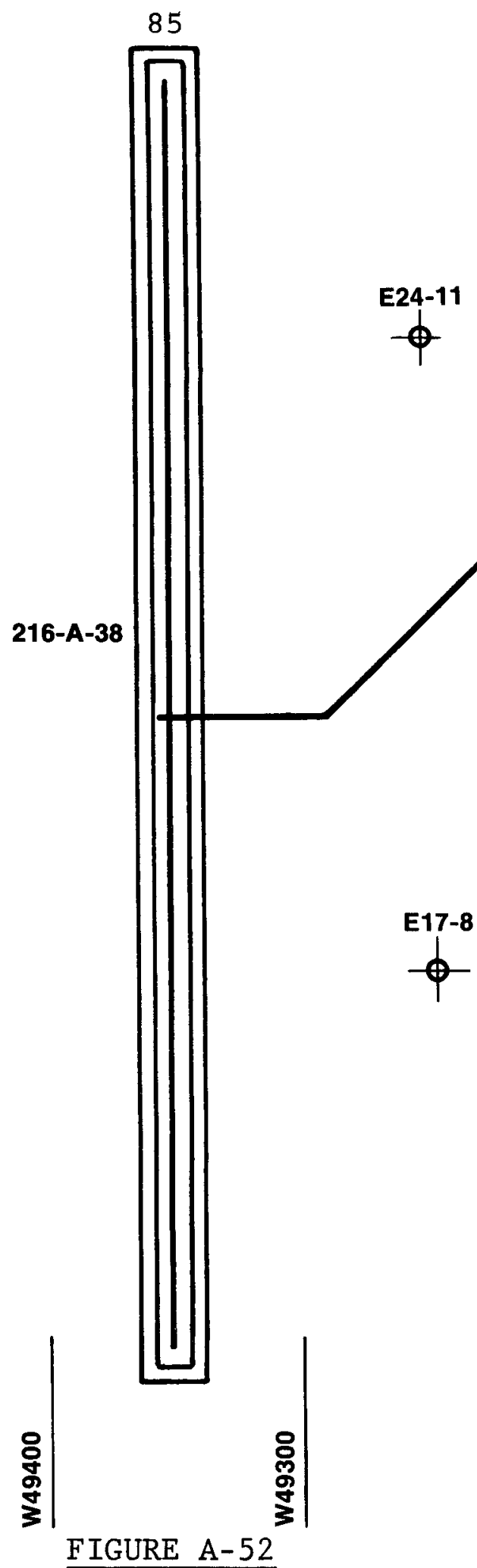

ARH-ST-156

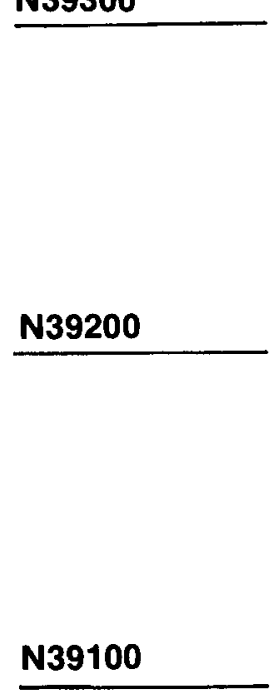

N39000

\begin{tabular}{l} 
\\
8 \\
8 \\
\hline \\
\hline \\
3
\end{tabular}

FIGURE A-52

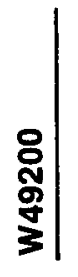




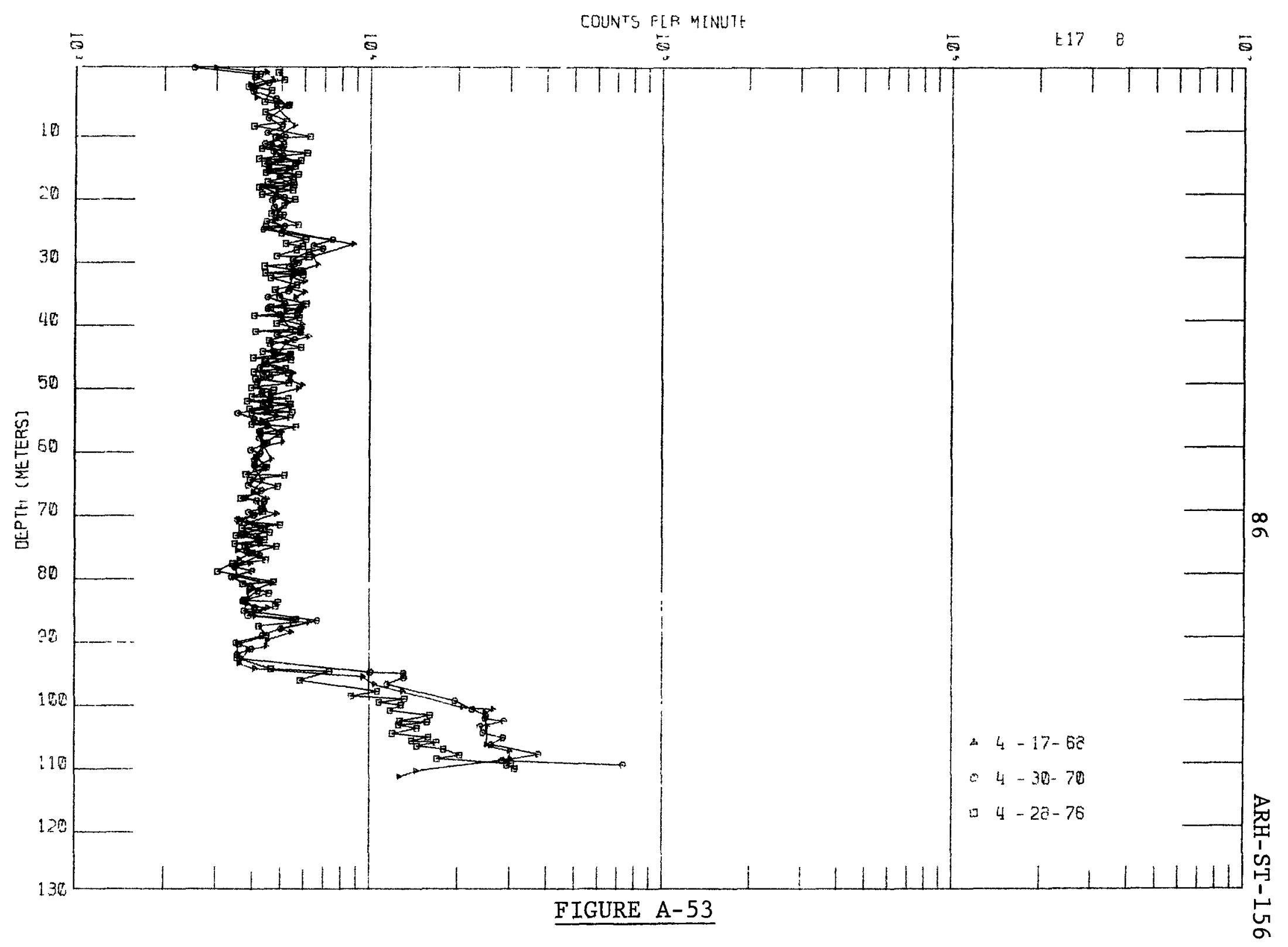

WELL E17-8 SCINTILLATION PROBE PROFILES 
C.

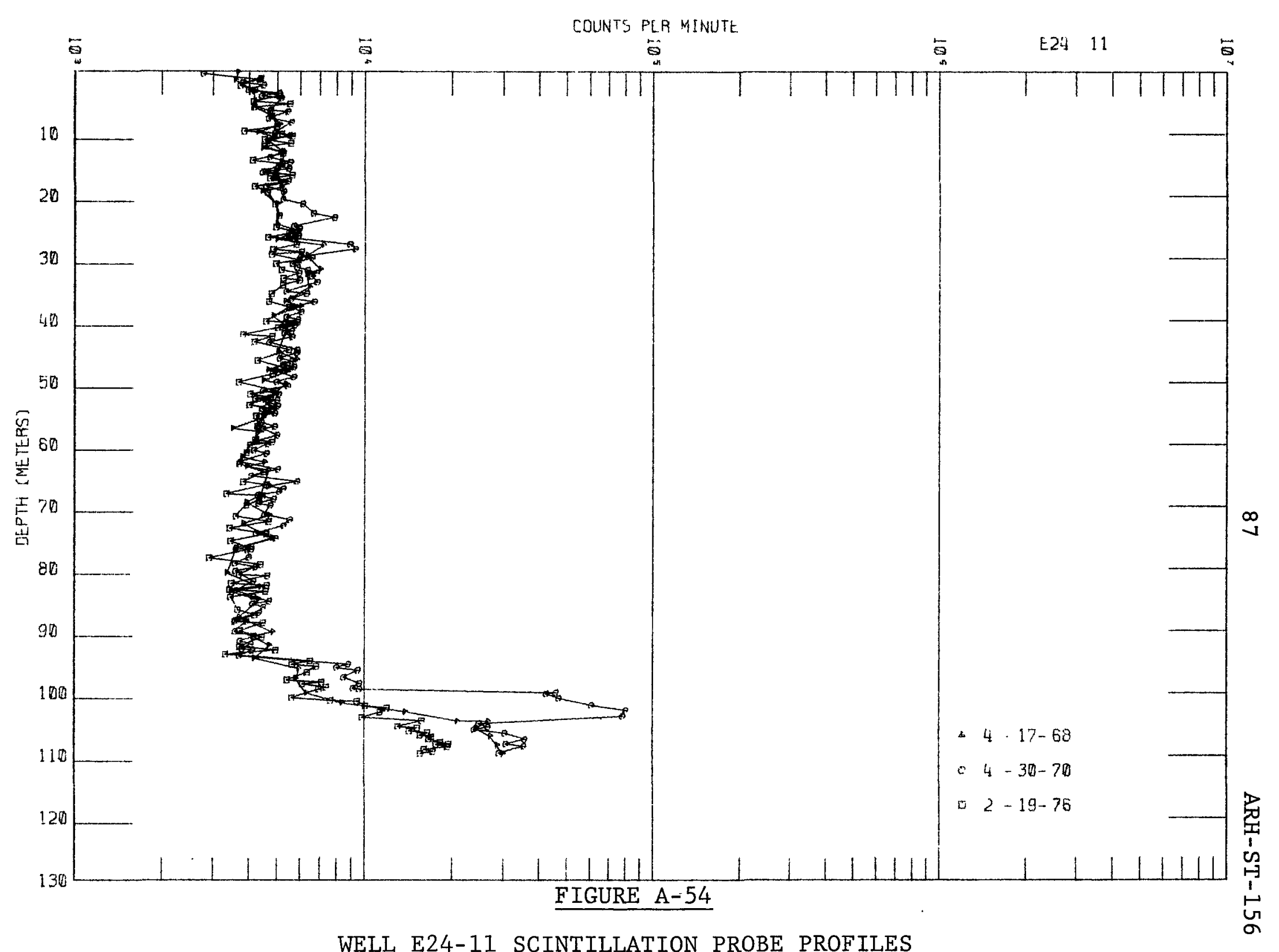

WELL E24-11 SCINTILLATION PROBE PROFILES 


\section{6-B-5 Reverse Well}

Description of Waste: Cell drainage and other liquid waste via Tank 5-6 in the 221-B Building.

Service Dates: 1945 to 1947

Waste Volume: $3.06 \times 10^{7}$ liters

Waste Inventory:

\begin{tabular}{ccc} 
& Total & Decayed Thru June 1976 \\
\cline { 2 - 3 } $\mathrm{Pu}, \mathrm{g}$ & $4.28 \times 10^{3}$ & $4.28 \times 10^{3}$ \\
$\mathrm{Beta}^{\mathrm{B}} \mathrm{Ci}$ & $3.80 \times 10^{3}$ & $1.51 \times 10^{2}$ \\
${ }^{0} \mathrm{Sr}, \mathrm{Ci}$ & $7.56 \times 10^{1}$ & $3.62 \times 10^{1}$ \\
${ }^{106} \mathrm{Ru}, \mathrm{Ci}$ & $1.63 \times 10^{2}$ & $1.93 \times 10^{-7}$ \\
${ }^{137} \mathrm{Cs}, \mathrm{Ci}$ & $8.07 \times 10^{1}$ & $4.05 \times 10^{1}$
\end{tabular}

Evaluation of Scintillation Probe Profiles:

We11 E28-7 monitors the 216-B-5 reverse well (figure A-1).

Only background activity is detected in the monitoring well which is

located 18.3 meters from the reverse well (figure A-55). The crib history is not reflected in the scintillation probe profiles.

The 216-B-5 Reverse Wel1 was drilled as a 20.3 centimeter well to a depth of 92.0 meters in 1944. Radioactive effluent was discharged to the reverse well via overflow from the 24l-B-361 tank.

In 1947 the elevation of the water table in well E33-18 demonstrated that the 216-B-5 reverse well penetrated about 3.0 meters into the groundwater and that radioactive waste had been discharged into the groundwater. The 5-6 wastes were rerouted to 216-B-7A and 7B cribs. Eleven wells were drilled around the reverse well to determine the extent of groundwater contamination. The zone of groundwater contamination $\left(<20 \times 10^{-7} \mu \mathrm{Ci} / 1 \mathrm{iter}\right)$ extended laterally only 600 meters from the reverse well. 


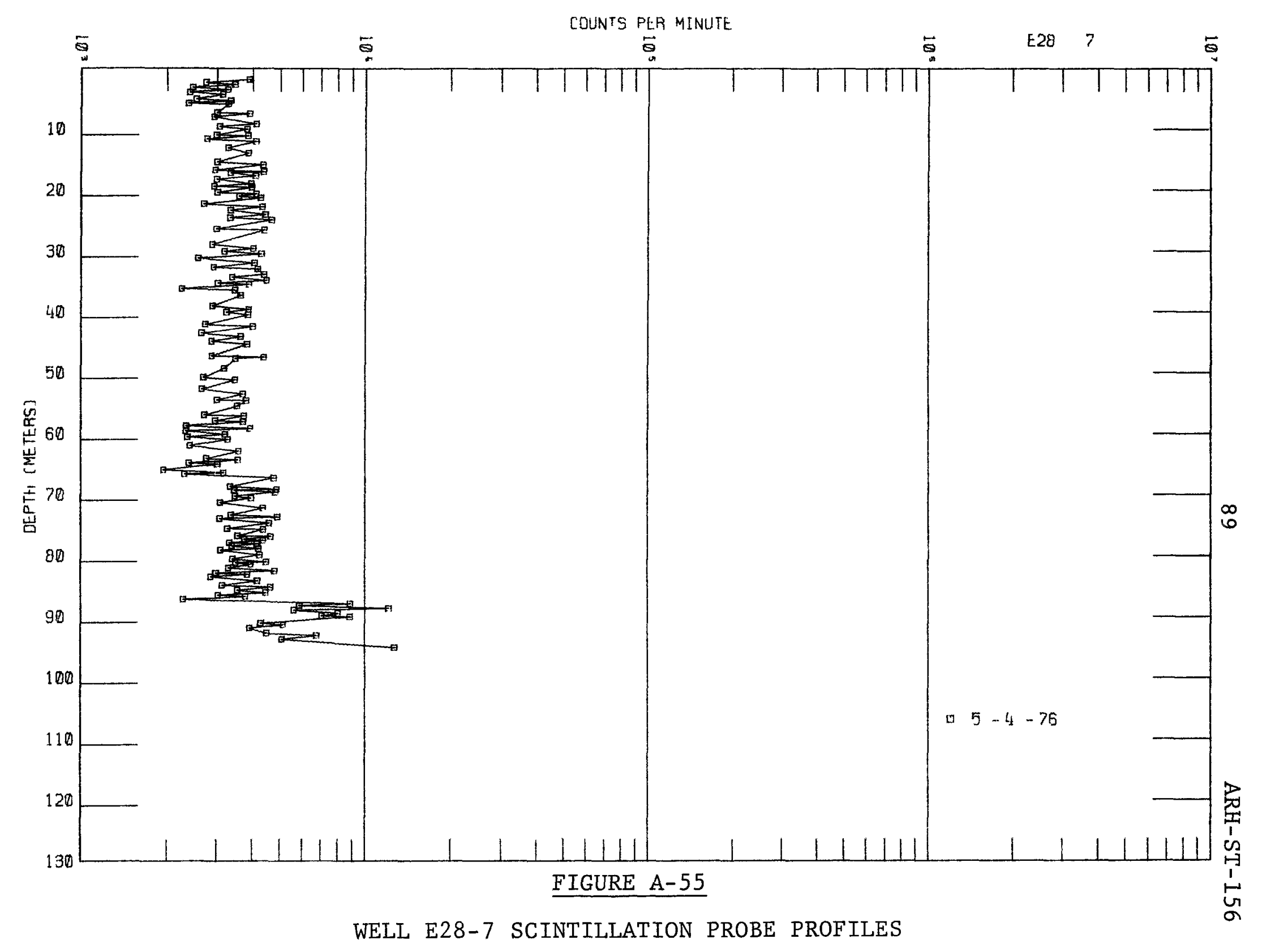


$276-B-7 A$ and $7 B$ Cribs

Description of Waste: Liquid waste from 224-B cell drainage, 227-B via Tank 5-6 and decontamination and construction waste during 224-B reactivation, decontamination and cleanup activities.

Service Dates: 1946 to 1955 and 1966 to 1967

Waste Volumes: $4.36 \times 10^{7}$ liters

Waste Inventory:

\begin{tabular}{rcc} 
& Total & Decayed Thru June 1976 \\
\cline { 2 - 3 } $\mathrm{Pu}, \mathrm{g}$ & $4.30 \times 10^{3}$ & $4.30 \times 10^{3}$ \\
$\mathrm{Beta}, \mathrm{Ci}$ & $2.42 \times 10^{4}$ & $6.38 \times 10^{3}$ \\
${ }^{90} \mathrm{Sr}, \mathrm{Ci}$ & $5.60 \times 10^{3}$ & $3.13 \times 10^{3}$ \\
${ }^{106} \mathrm{Ru}, \mathrm{Ci}$ & $6.00 \times 10^{2}$ & $5.23 \times 10^{-5}$ \\
${ }^{137} \mathrm{Cs}, \mathrm{Ci}$ & $1.00 \times 10^{2}$ & $5.99 \times 10^{1}$ \\
${ }^{60} \mathrm{Co}, \mathrm{Ci}$ & $1.00 \times 10^{0}$ & $4.24 \times 10^{-2}$ \\
$\mathrm{U}, \mathrm{kg}$ & $1.82 \times 10^{2}$ & $1.82 \times 10^{2}$
\end{tabular}

Evaluation of Scintillation Probe Profiles:

Wells E33-18, E33-58, E33-59, and E33-75 monitor the 216-B.-7A and $7 B$ cribs (figures $A-1$ and $A-56$ ). In 1963 radioactive contaminants were detected at the ground surface in Well E33-59 (figure A-57). By 1976 the radiation intensity had decreased to background. The major zone of contamination is located between 1.0 and 18.3 meters below the distributor pipe (4.6 to 21.9 meters below the ground surface, figures A-57, A-58, and $A-59)$. The radiation intensity of the contaminated zone is decreasing in wells E33-58 and E33-59. In Well E33-75 the radiation intensity remains unchanged. Only background radiation has been detected in Wel1 E33-18 (figure A-60).

On the basis of these scintillation probe profiles no measurable down ward migration of radionuclides in the major zone of contamination 
beneath the 216-A-7 cribs has been detected. The $1.13 \times 10^{7}$ 1iters discharged in 1966 and 1967, 11 years after the crib had last been used, has had little effect on moving the radionuclides previously discharged to the ground. The decrease in radiation intensity near the ground surface in Well E33-59 could be due to either migration or decay of radionuclides in the sediments. The data indicate breakthrough to the groundwater has not occurred at this site. 


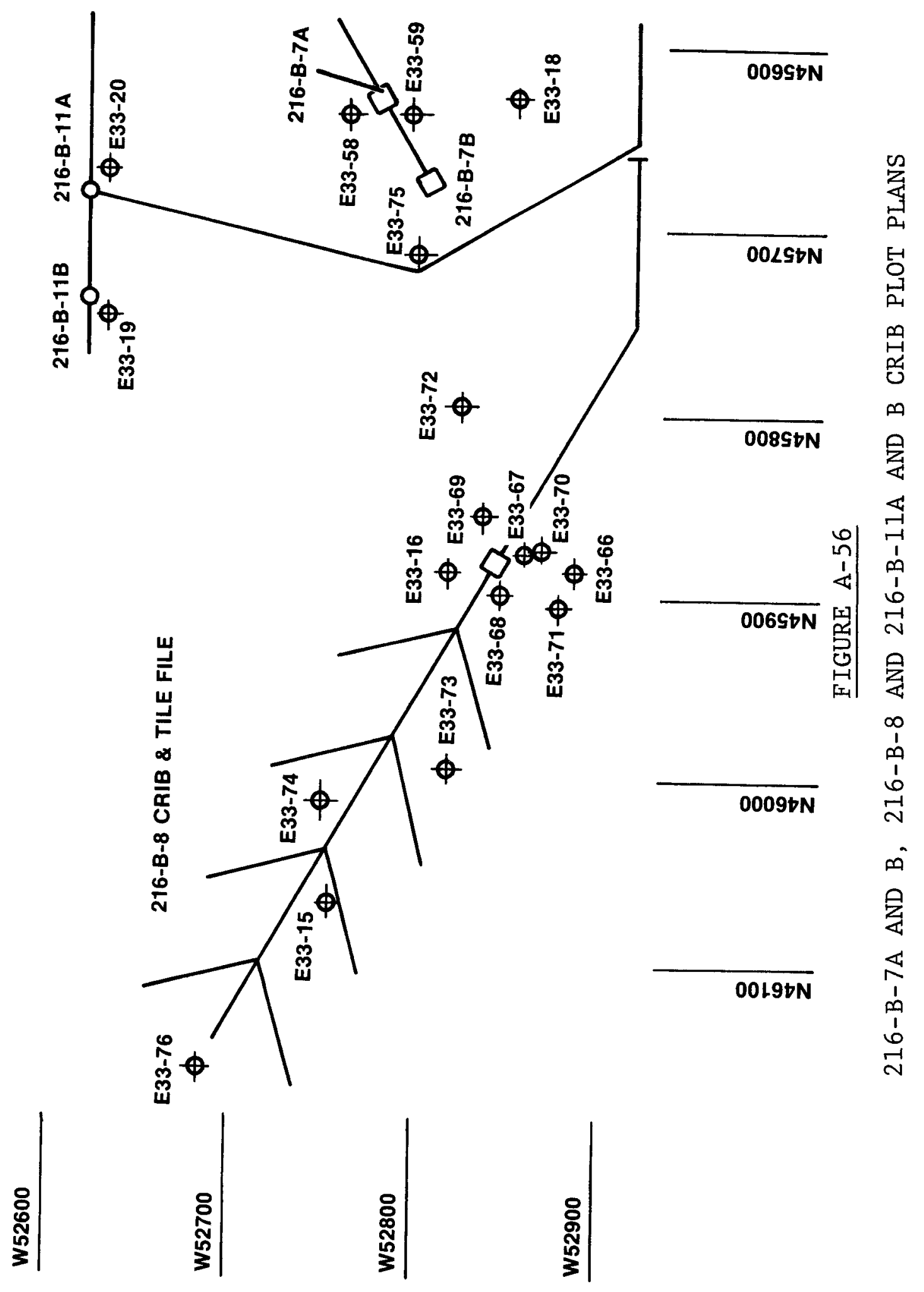




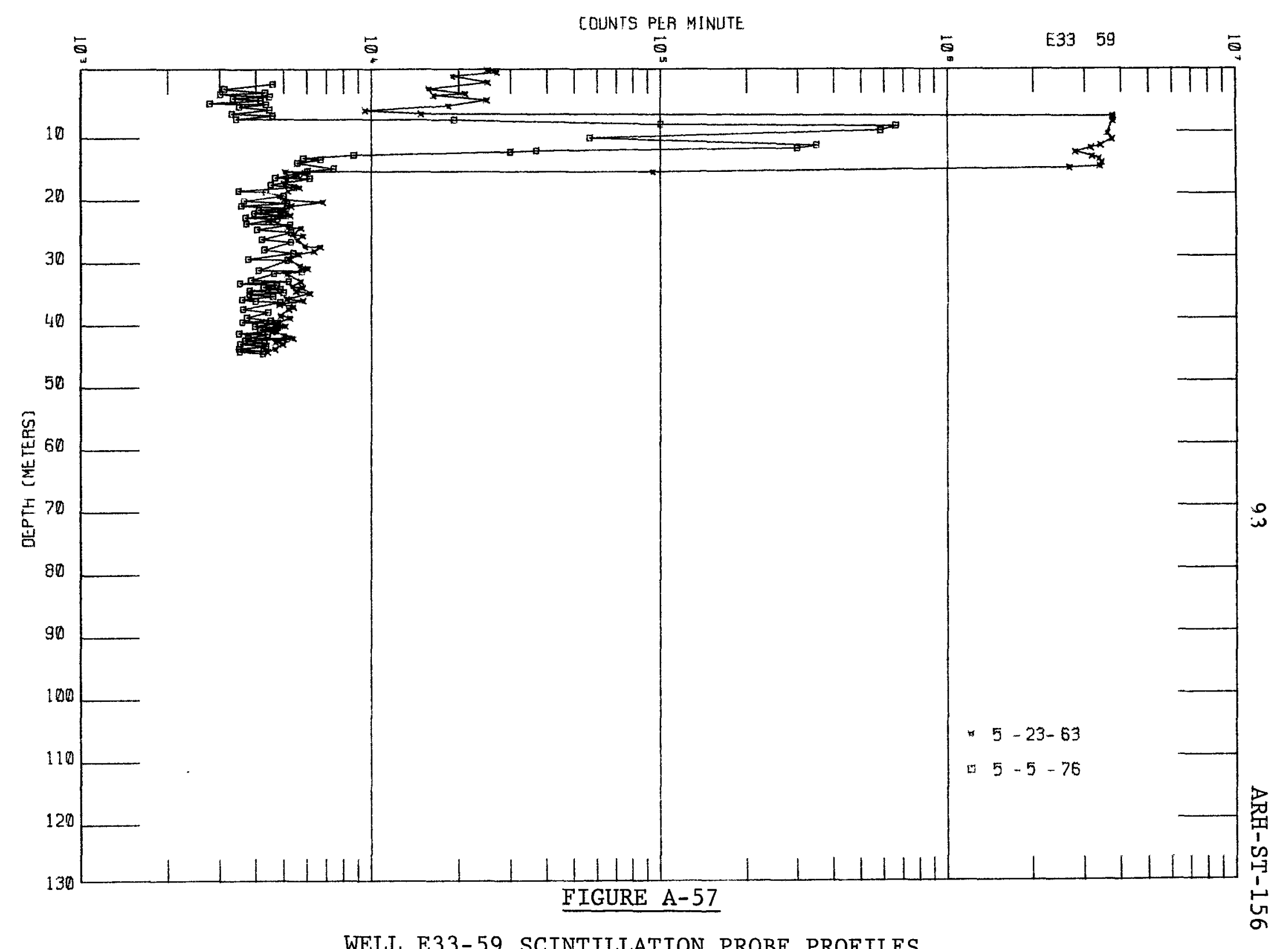

WELL E33-59 SCINTILLATION PROBE PROFILES 
C.

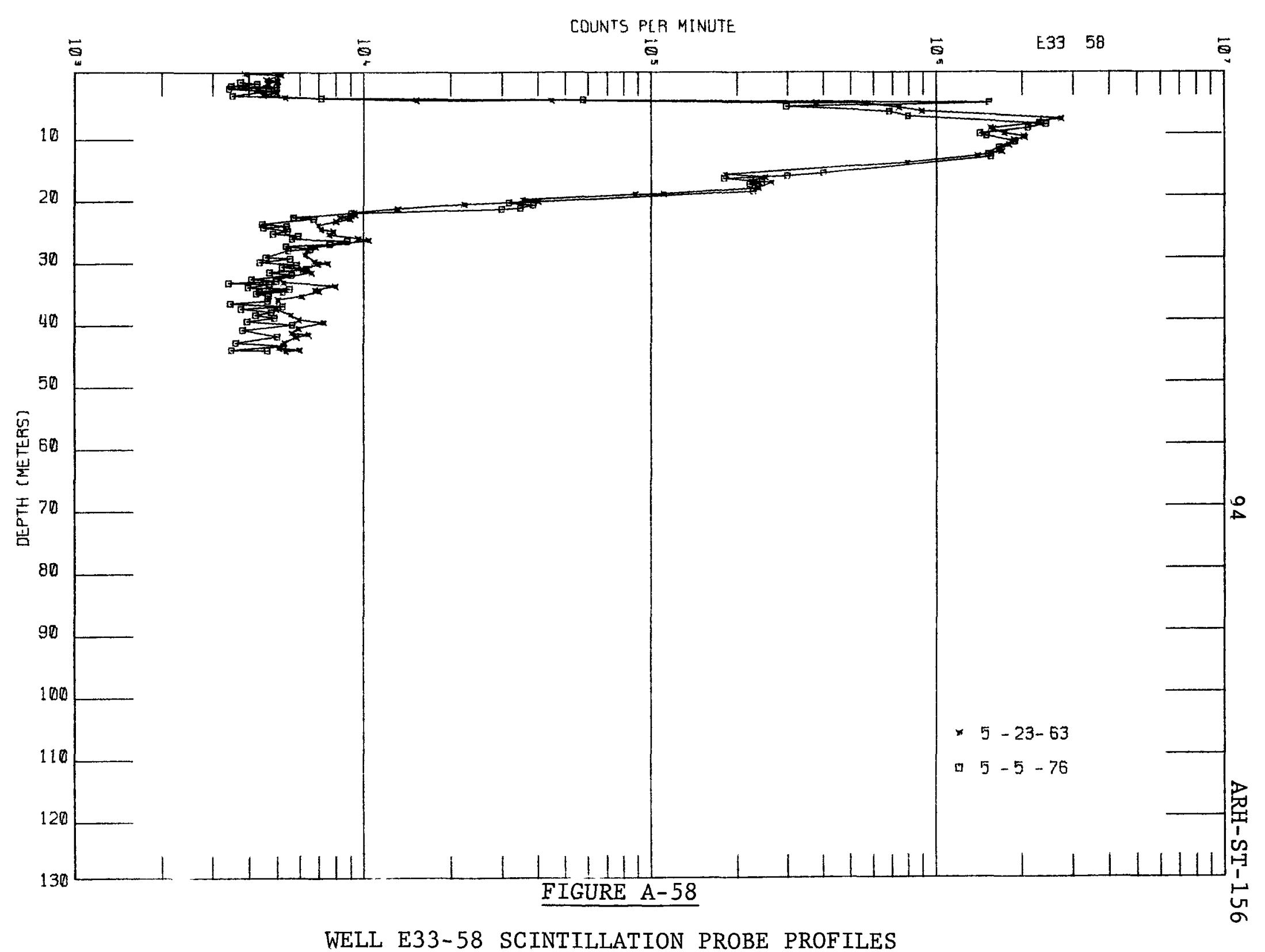


C.

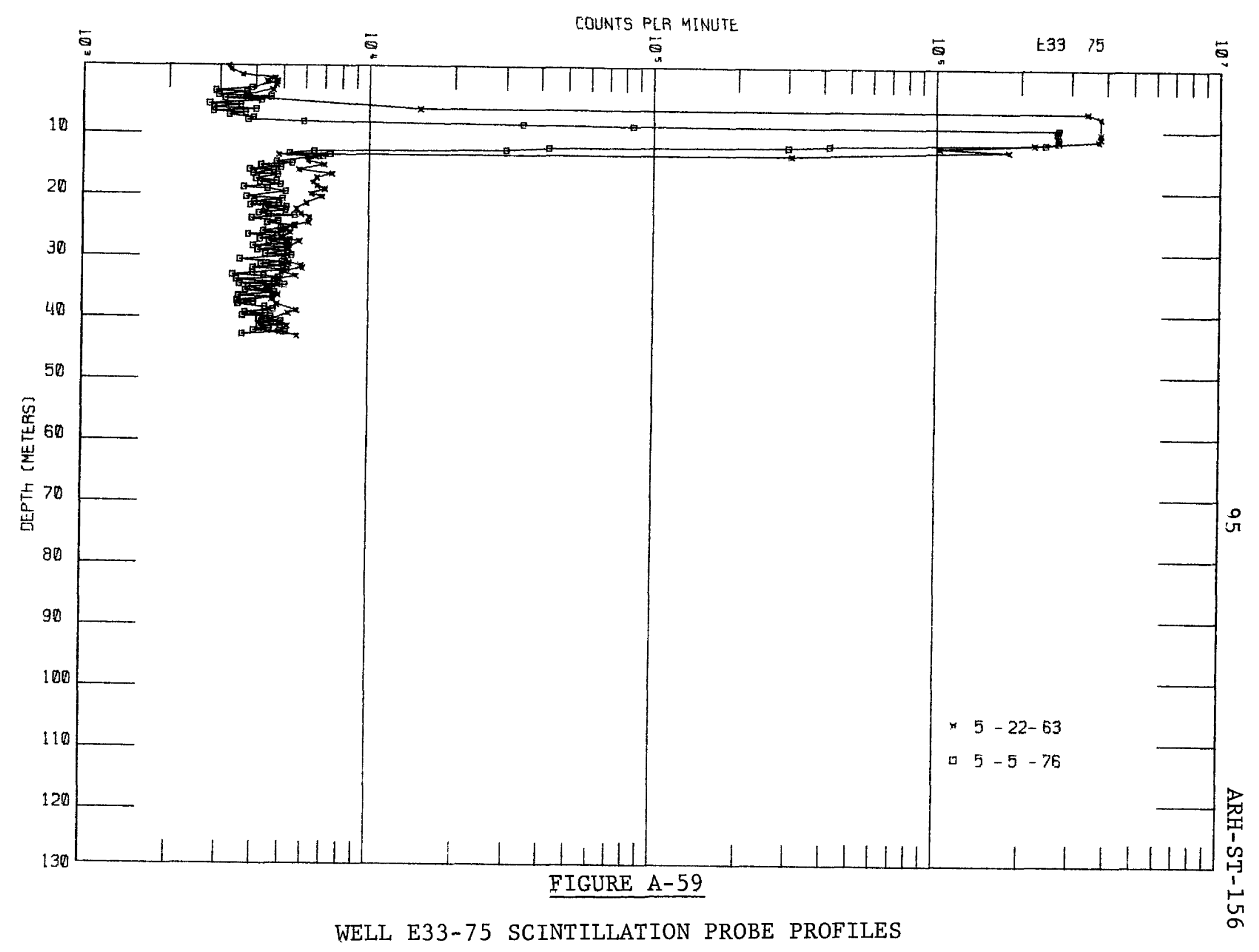


C.

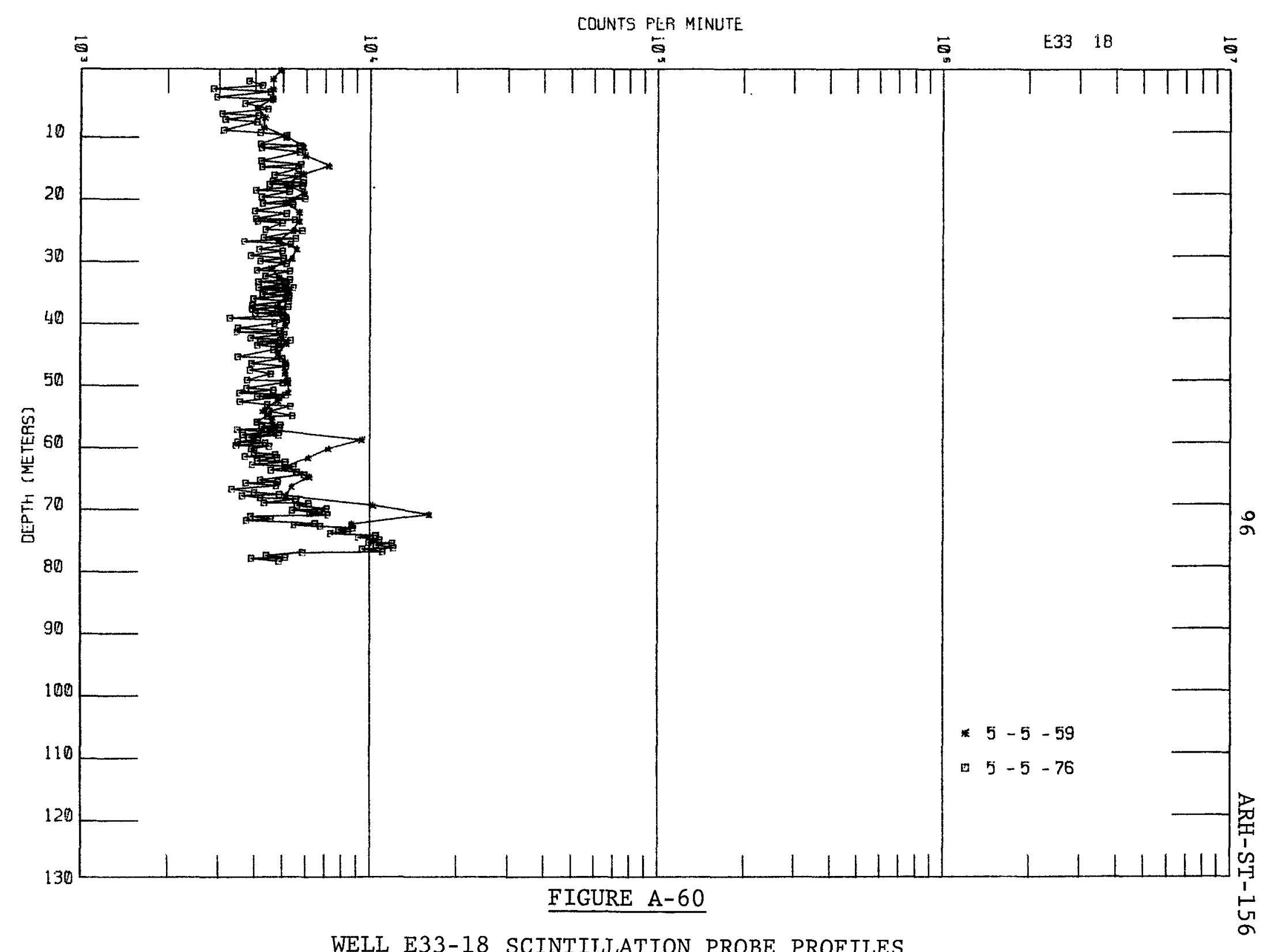




\section{6-B-8 Crib and Tile Field}

Description of Waste: Second cycle waste from 221-B, cell drainage and other liquid waste via tank 5-6 in 221-B, and liquid waste from 224-B.

Service Dates: 1948 to 1953

Waste Volume: $2.72 \times 10^{7}$ liters

Waste Inventory:

\begin{tabular}{rcc} 
& Total & Decayed Thru June 1976 \\
\cline { 2 - 3 } Pu, g & $3.00 \times 10^{1}$ & $3.00 \times 10^{2}$ \\
Beta, Ci & $7.10 \times 10^{2}$ & $6.88 \times 10^{1}$ \\
${ }^{90} \mathrm{Sr}, \mathrm{Ci}$ & $1.50 \times 10^{7}$ & $7.92 \times 10^{0}$ \\
${ }^{106} \mathrm{Ru}, \mathrm{Ci}$ & $5.00 \times 10^{7}$ & $1.33 \times 10^{-6}$ \\
${ }^{137} \mathrm{Cs}, \mathrm{Ci}$ & $5.00 \times 10^{7}$ & $2.75 \times 10^{7}$ \\
${ }^{60} \mathrm{Co}, \mathrm{Ci}$ & $1.00 \times 10^{0}$ & $3.30 \times 10^{-2}$ \\
U, kg & $4.54 \times 10^{1}$ & $4.54 \times 10^{7}$
\end{tabular}

Evaluation of Scintillation Probe Profiles:

Wells E33-16, E33-66, E33-67, E33-68, E33-69, E33-70, E33-71, E33-72 and E33-89 monitor the 216-B-8 crib. Wells E33-15, E33-73, E33-74 and E33-76 monitor the 216-B-8 tile field (fiqures $A-1$ and A-56). The major zone of contamination is found between 0.6 meters above the crib bottom ( 4.6 meters below the crib bottom) and approximately 28.3 meters below the crib bottom (figures A-61 through A-73). The scintiliation probe profile from We11 E33-72, located 23.8 meters south of the crib, shows background radiation intensity (figure A-74).

The 216-B-8 crib and tile field was taken out of service after sludge was inadvertently discharged to the crib from the 241-B-104 tank in August, 1948. A sudden decrease in crib capacity led to the discovery that approximately 0.4 meters of sludge was in the crib. The radioactive contaminants in the sludge were three orders of magnitude higher than 
the liquid supernatant from the 241-B-104 tank. With the highly permeable sediments and readily soluble sludge, radioactive contaminants moved downward and laterally from crib discharges subsequent to the introduction of sludge. This accounts for the distribution of contamination beneath the 216-B-8 crib as seen in the scintillation probe profiles in 1976.

On the basis of the scintillation probe profiles no measurable migration of radionuclides beneath the 216-B-8 crib and tile field has been detected. Most of the contamination discharged to the ground is found beneath the crib. The slow rate of decrease in radiation intensity shown in the profiles is due to the presence of long-lived radionuclides, principally ${ }^{60} \mathrm{Co}$ and ${ }^{137} \mathrm{Cs}$. These data indicate breakthrough to the groundwater has not occurred at this site. 


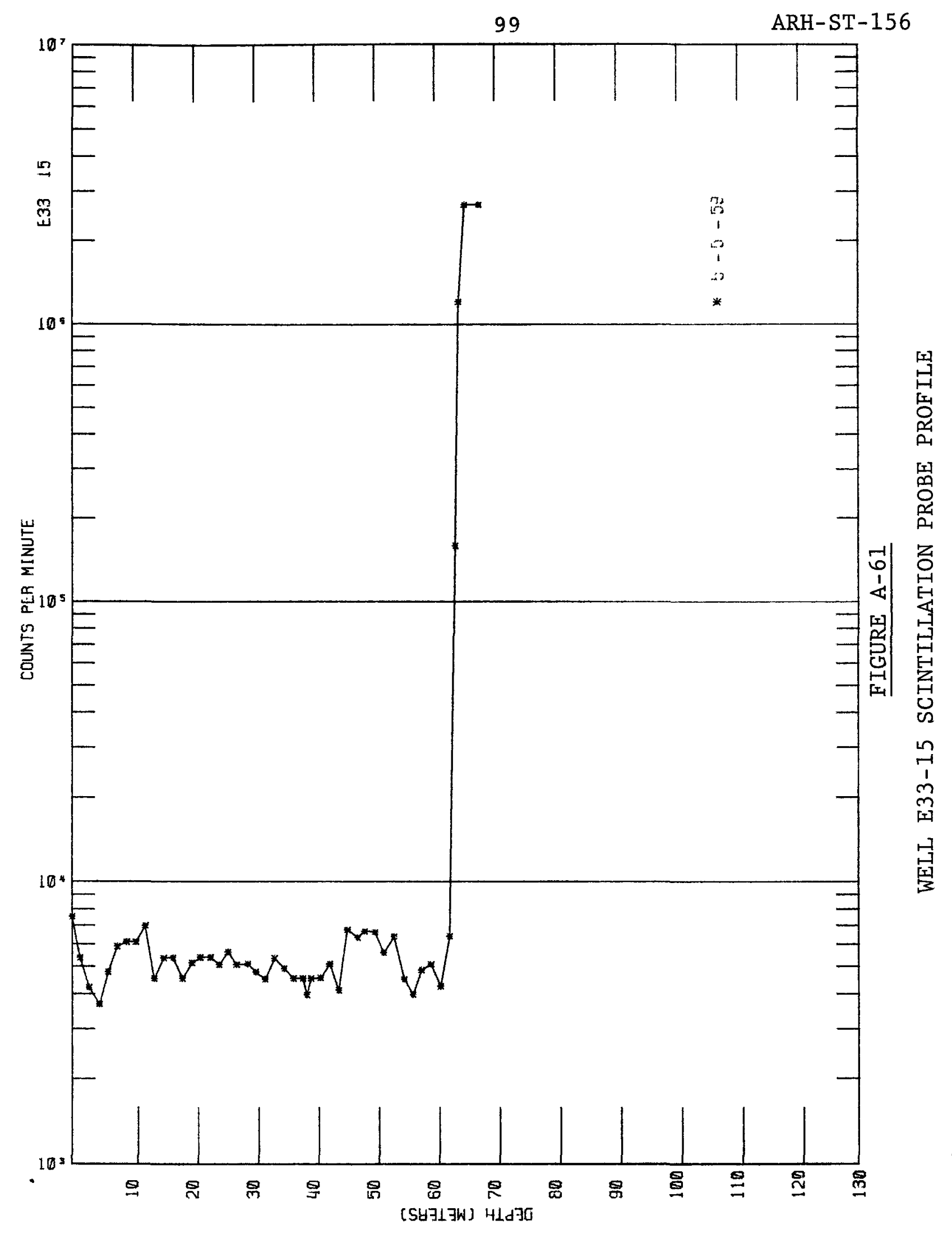




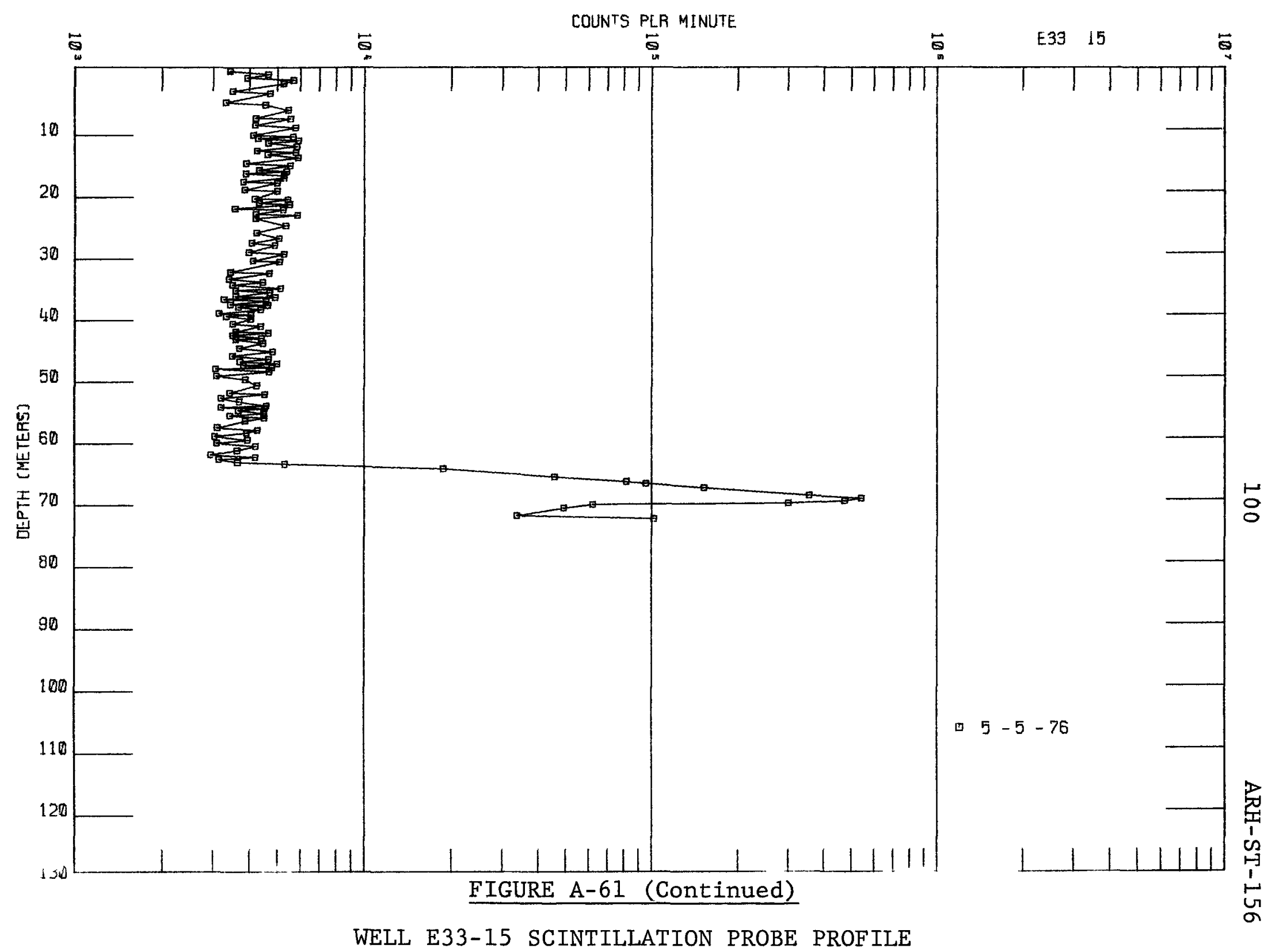




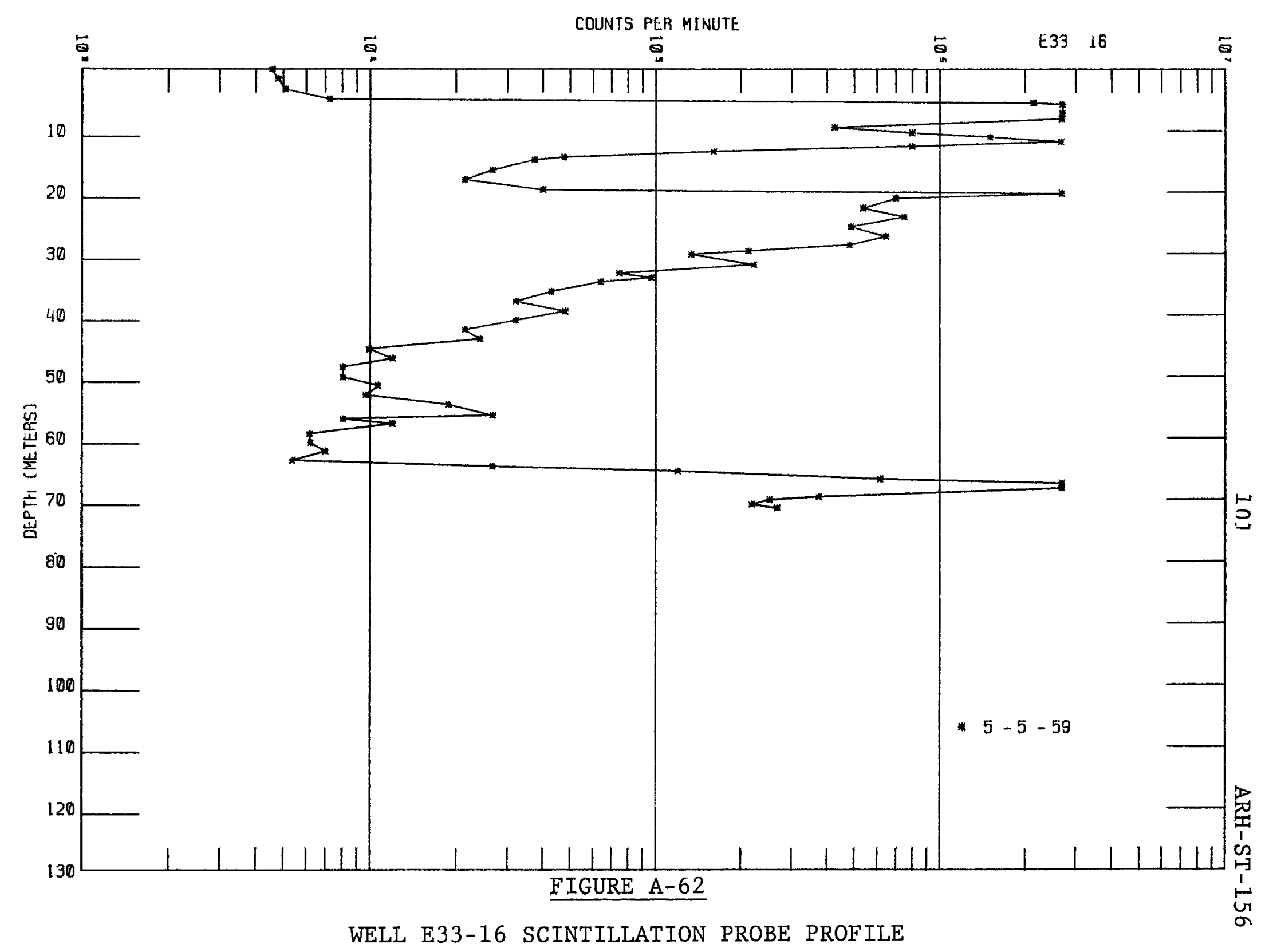




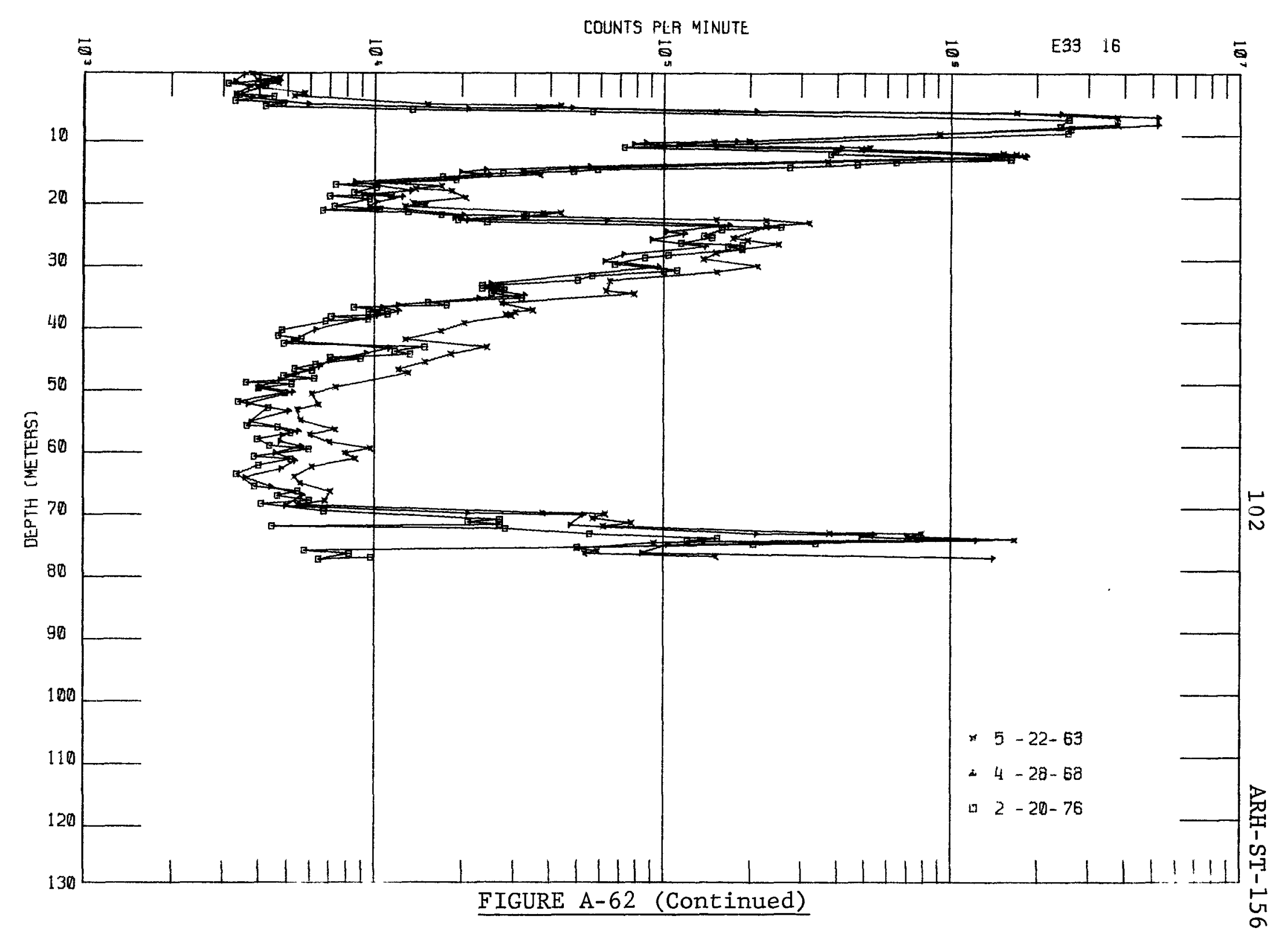

WELL E33-16 SCINTILLATION PROBE PROFILES 


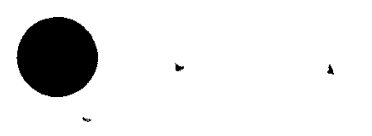

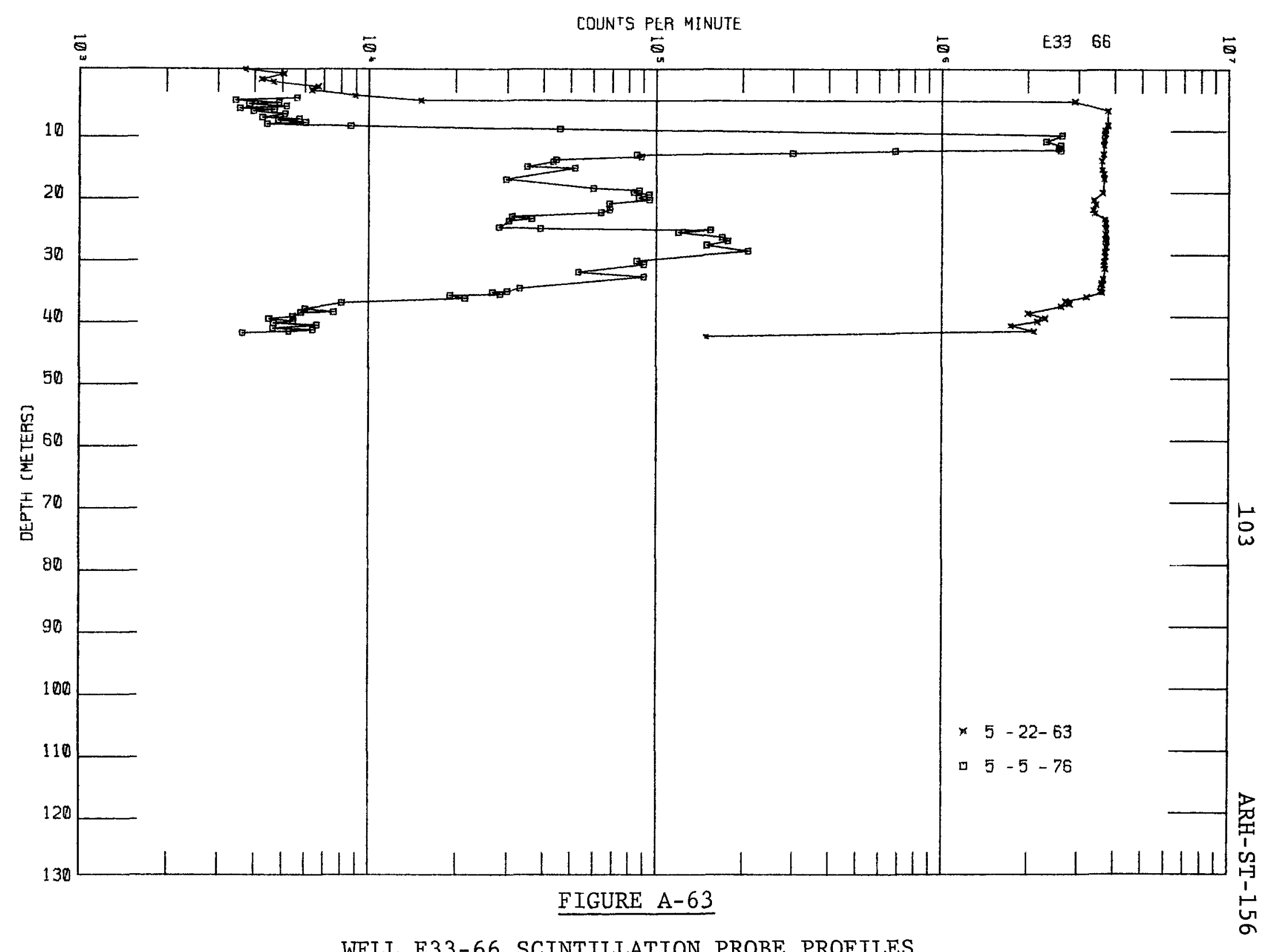

WELL E33-66 SCINTILLATION PROBE PROFILES 
C.

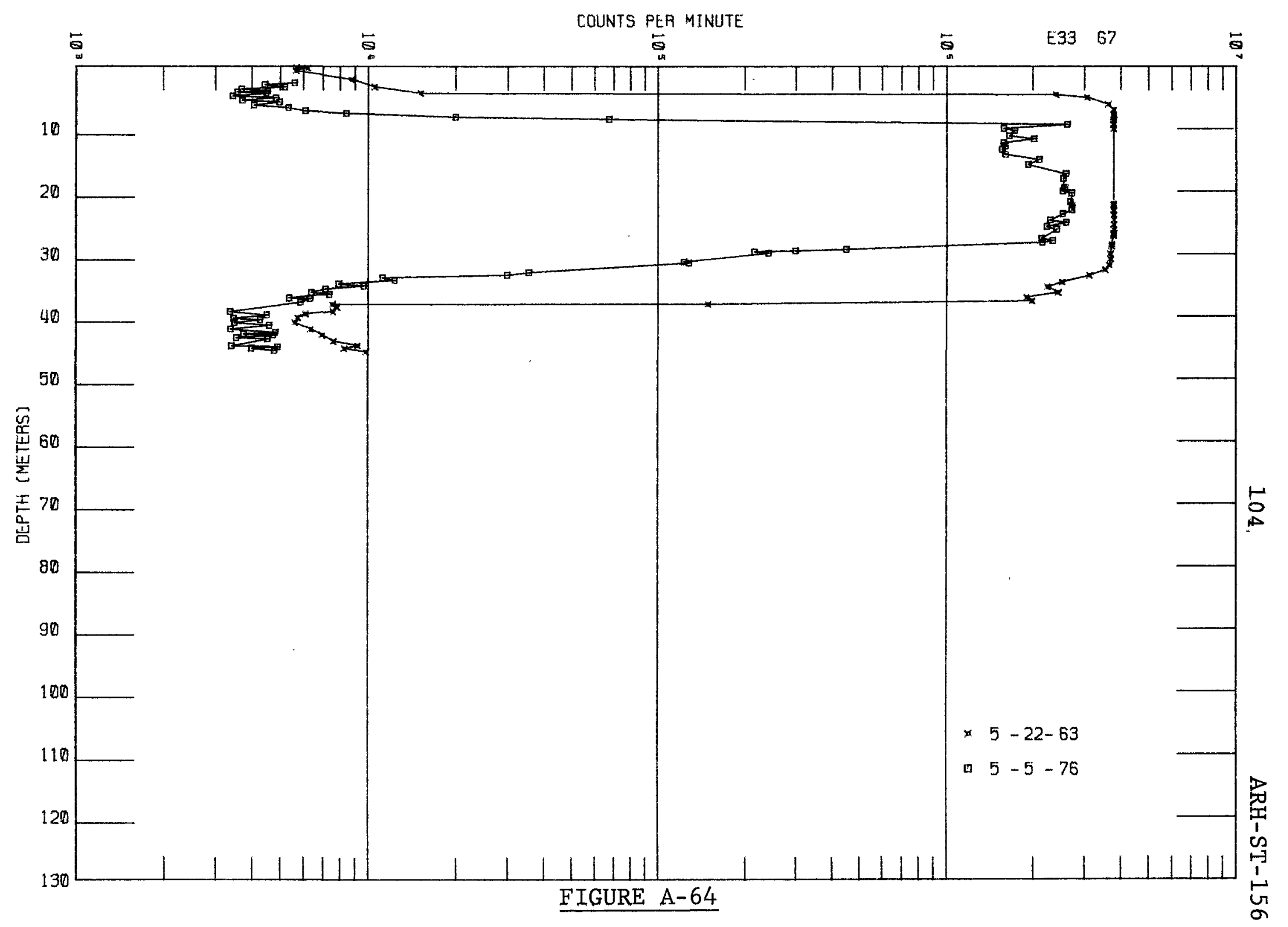

WELL E33-67 SCINTILLATION PROBE PROFILES 
$\bigoplus \cdot$

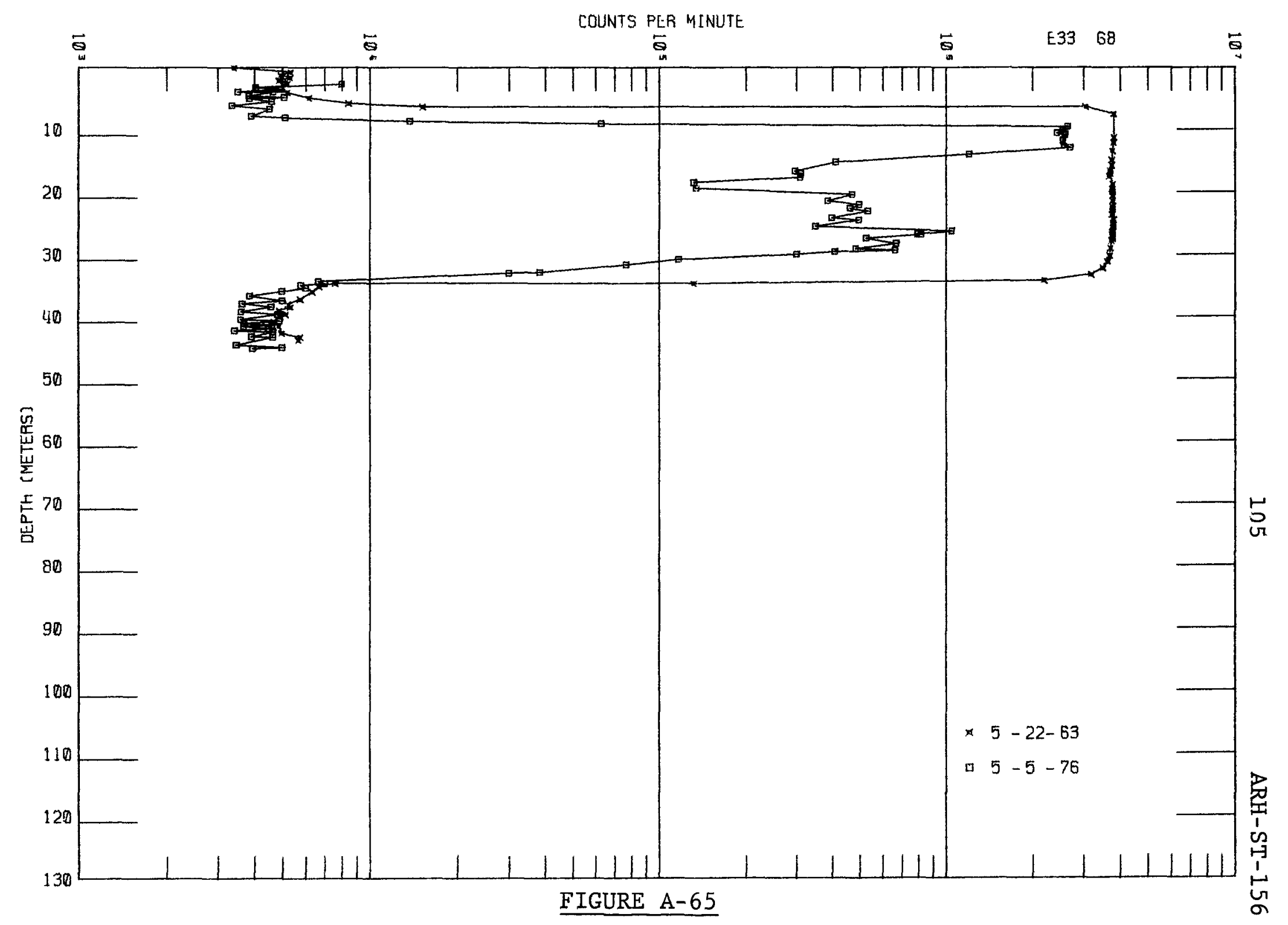

WELL E33-68 SCINTILLATION PROBE PROFILES 


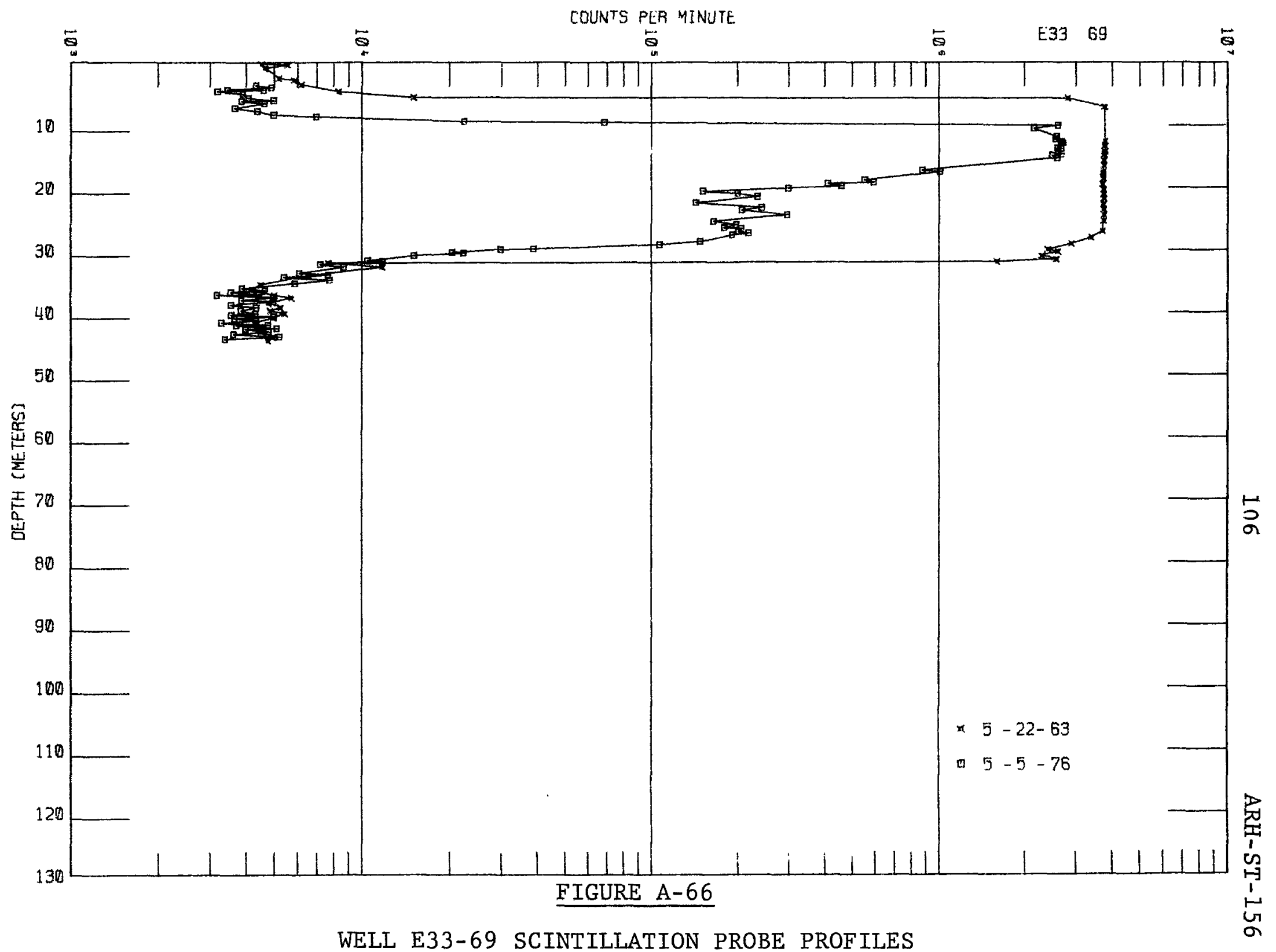




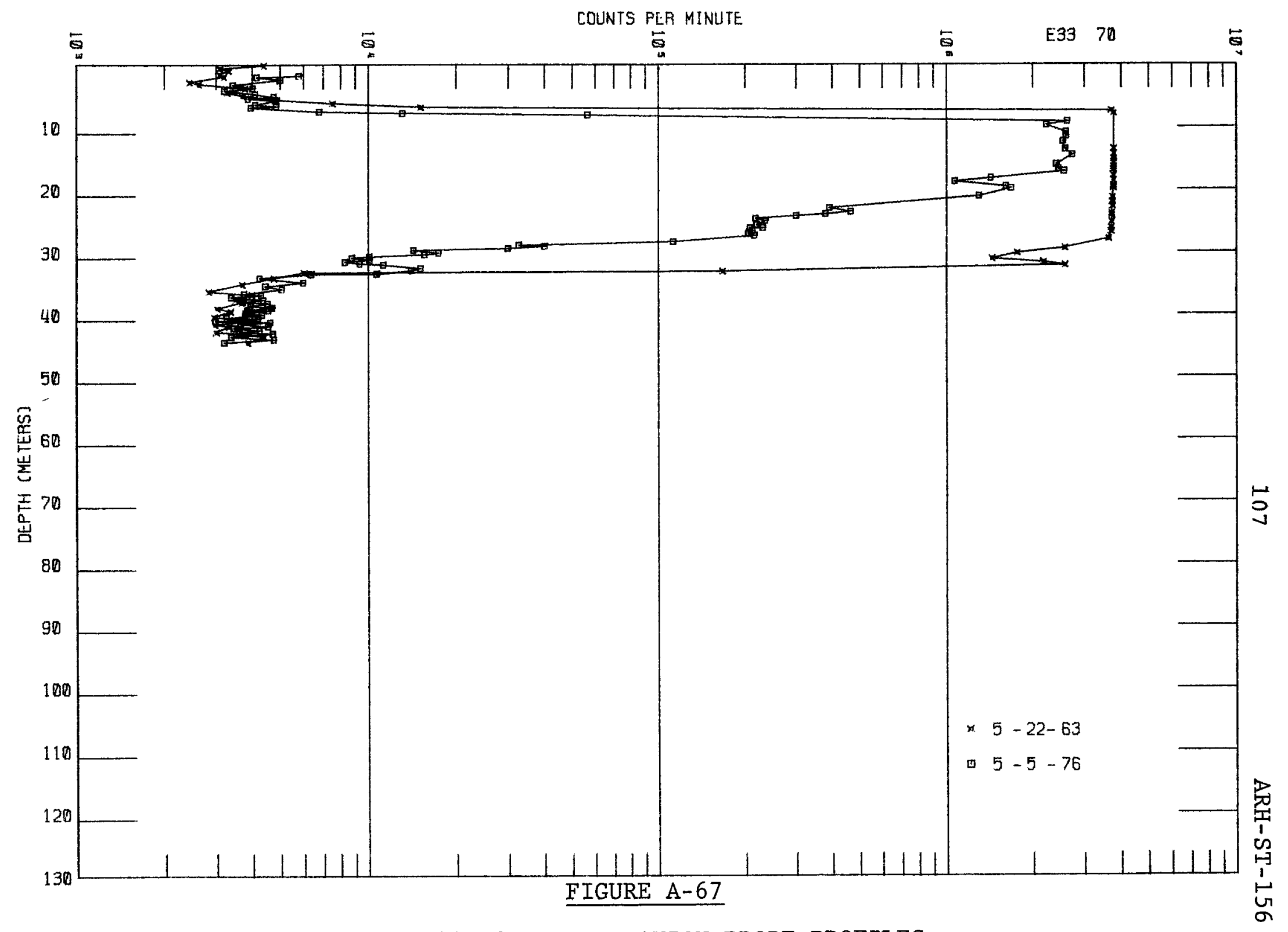

WELL E33-70 SCINTILLATION PROBE PROFILES 


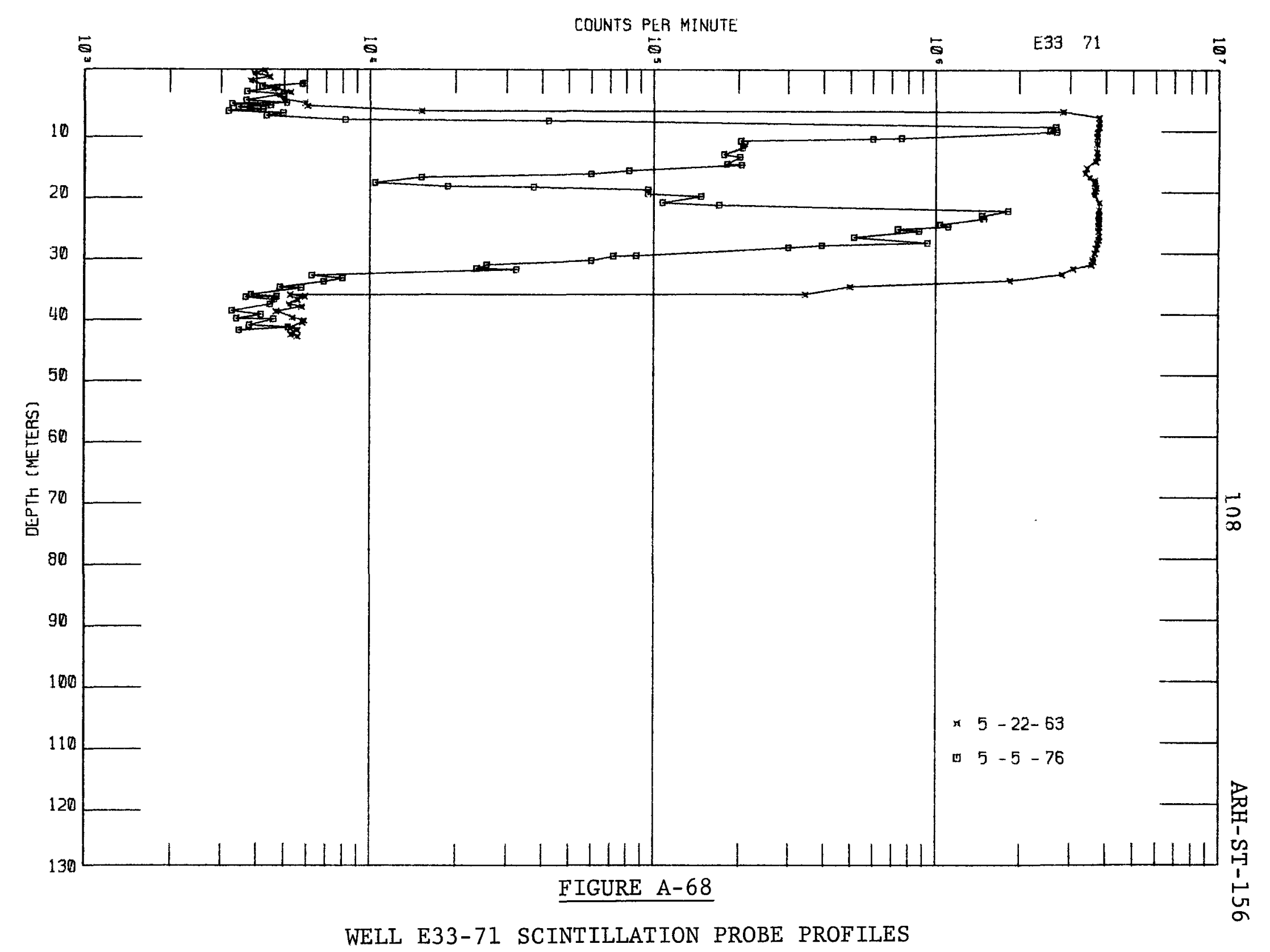




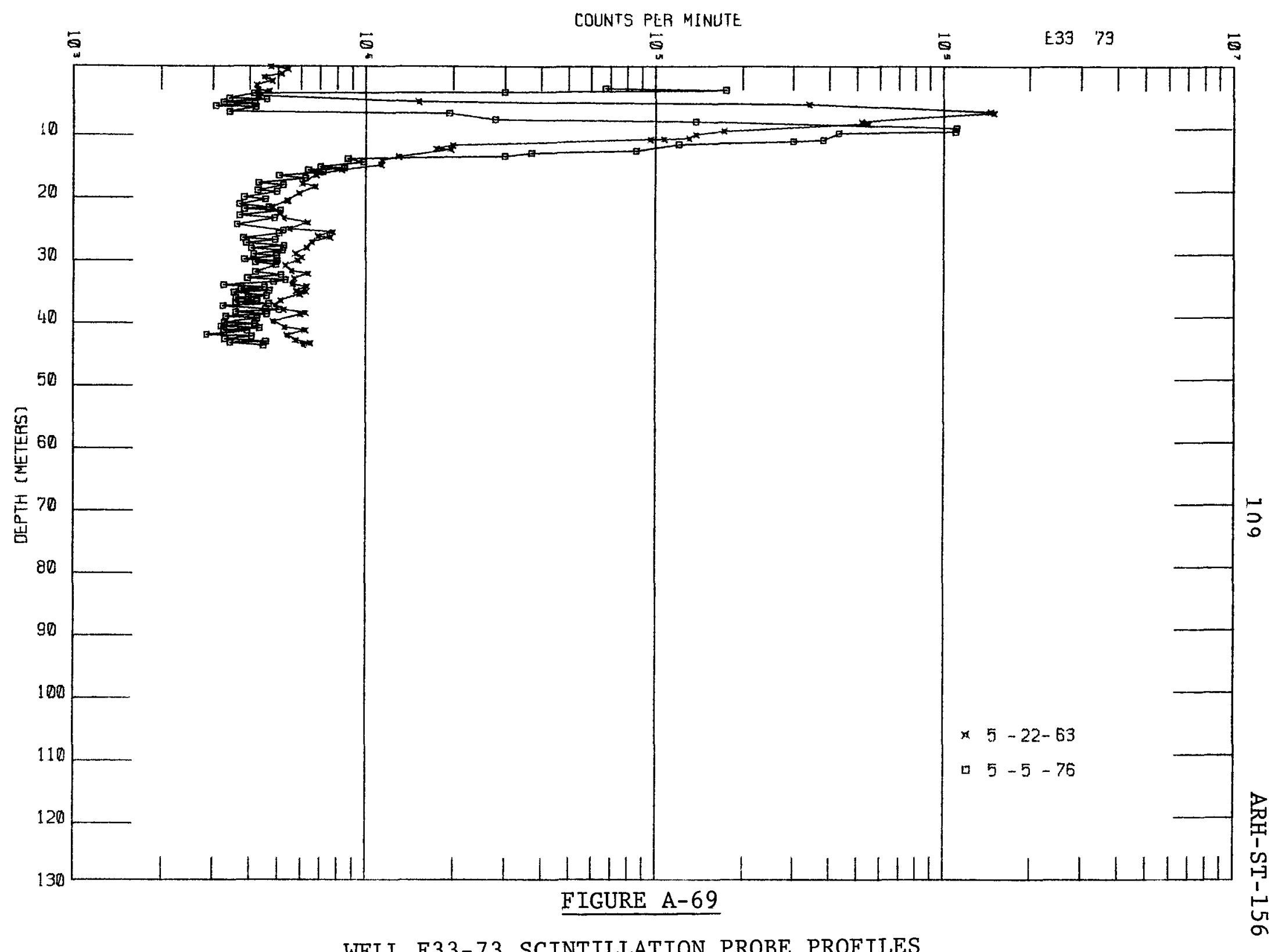

WELL E33-73 SCINTILLATION PROBE PROFILES 


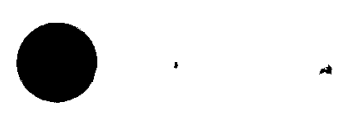

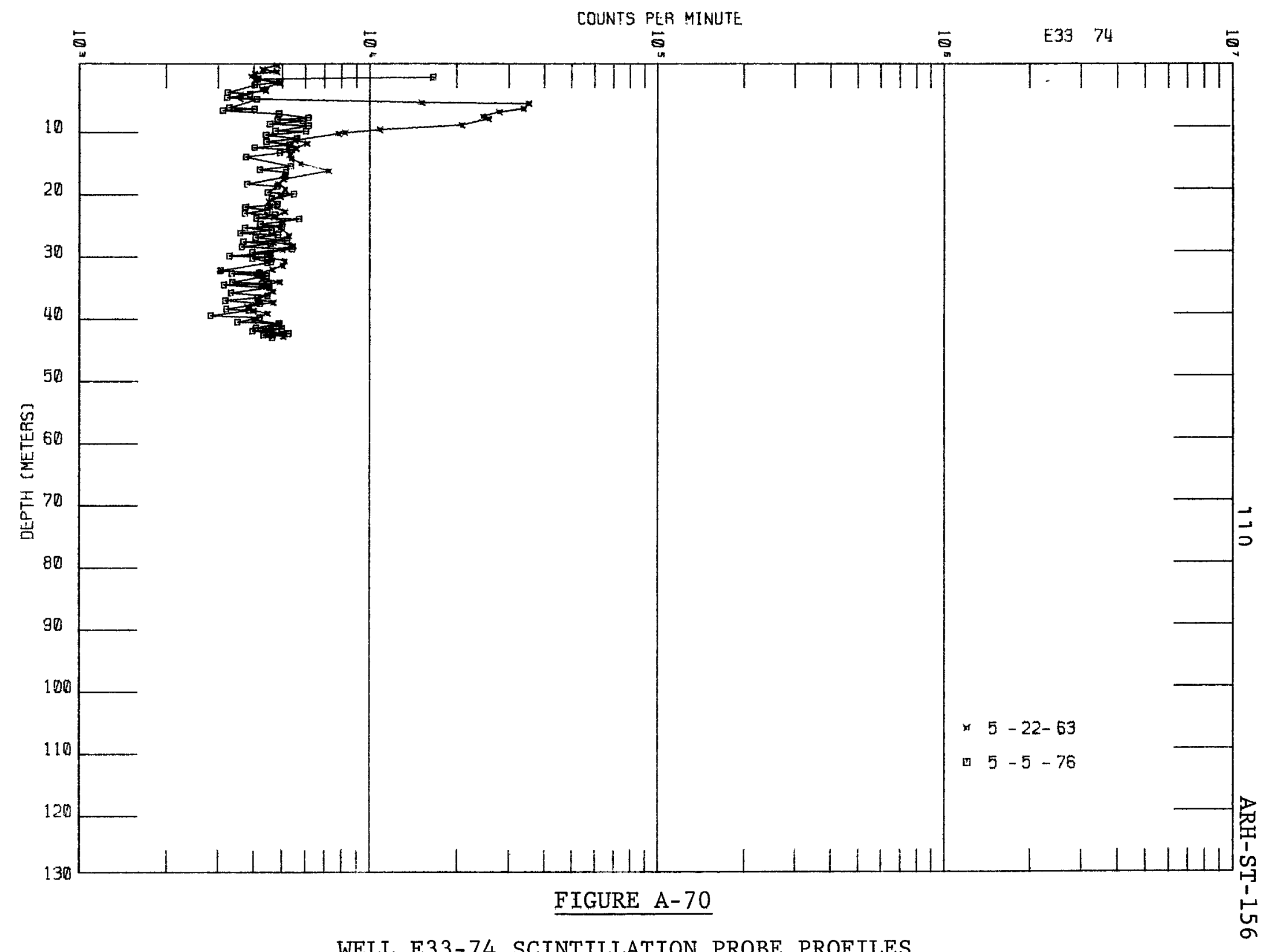

WELL E33-74 SCINTILLATION PROBE PROFILES 


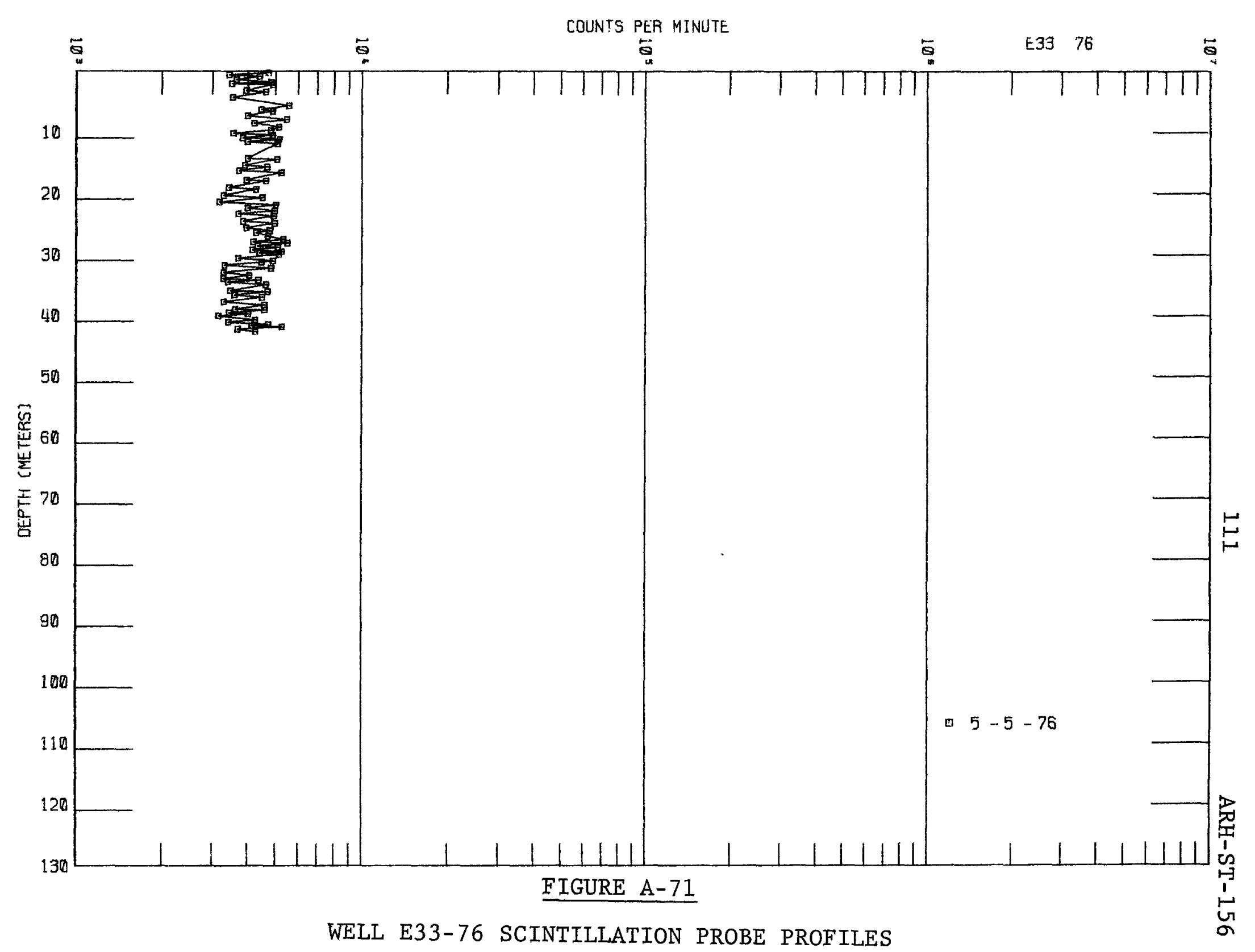




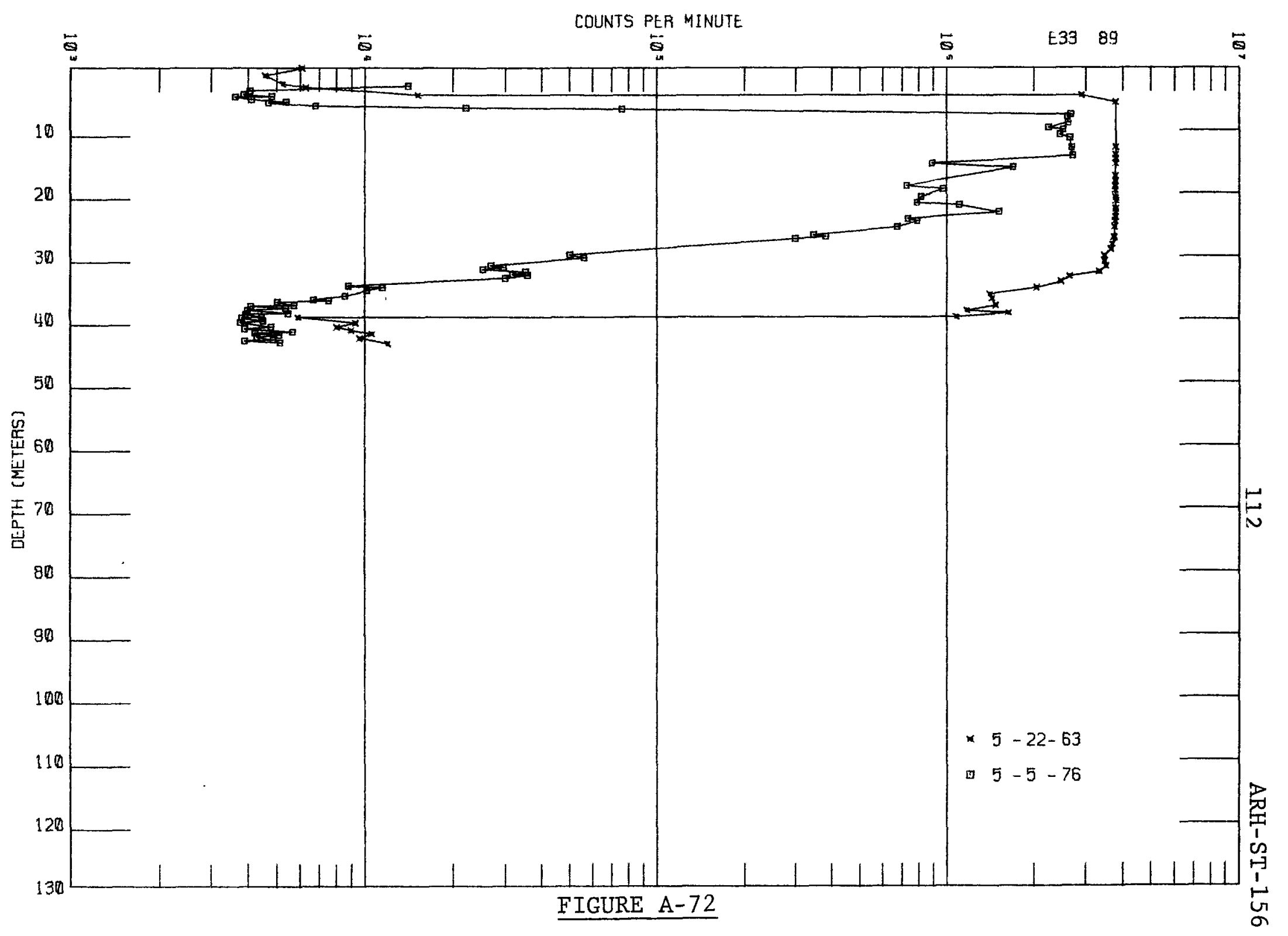

WELL E33-89 SCINTILLATION PROBE PROFILES 
P 1

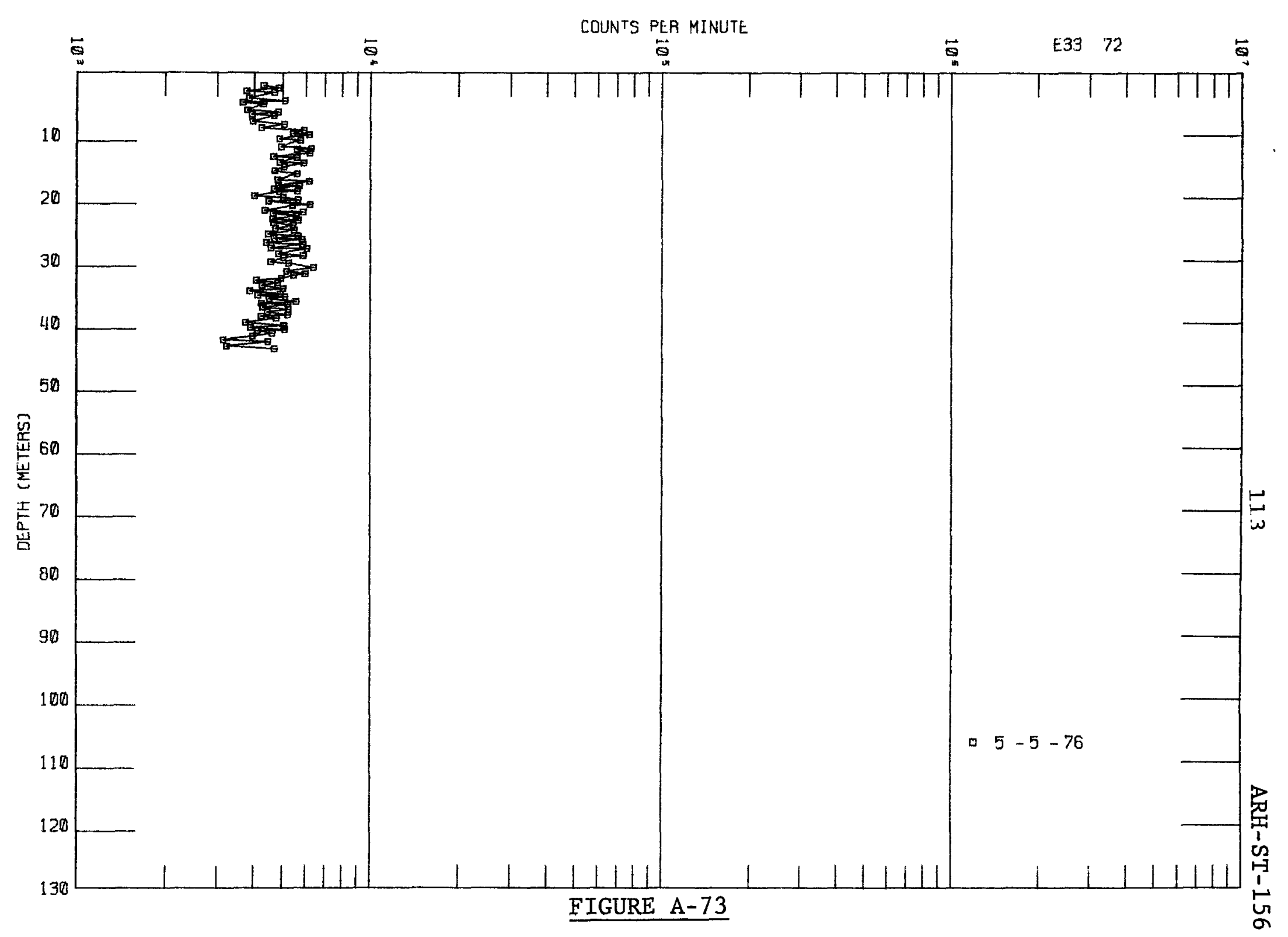

WELL E33-72 SCINTILIATION PROBE PROFILE 


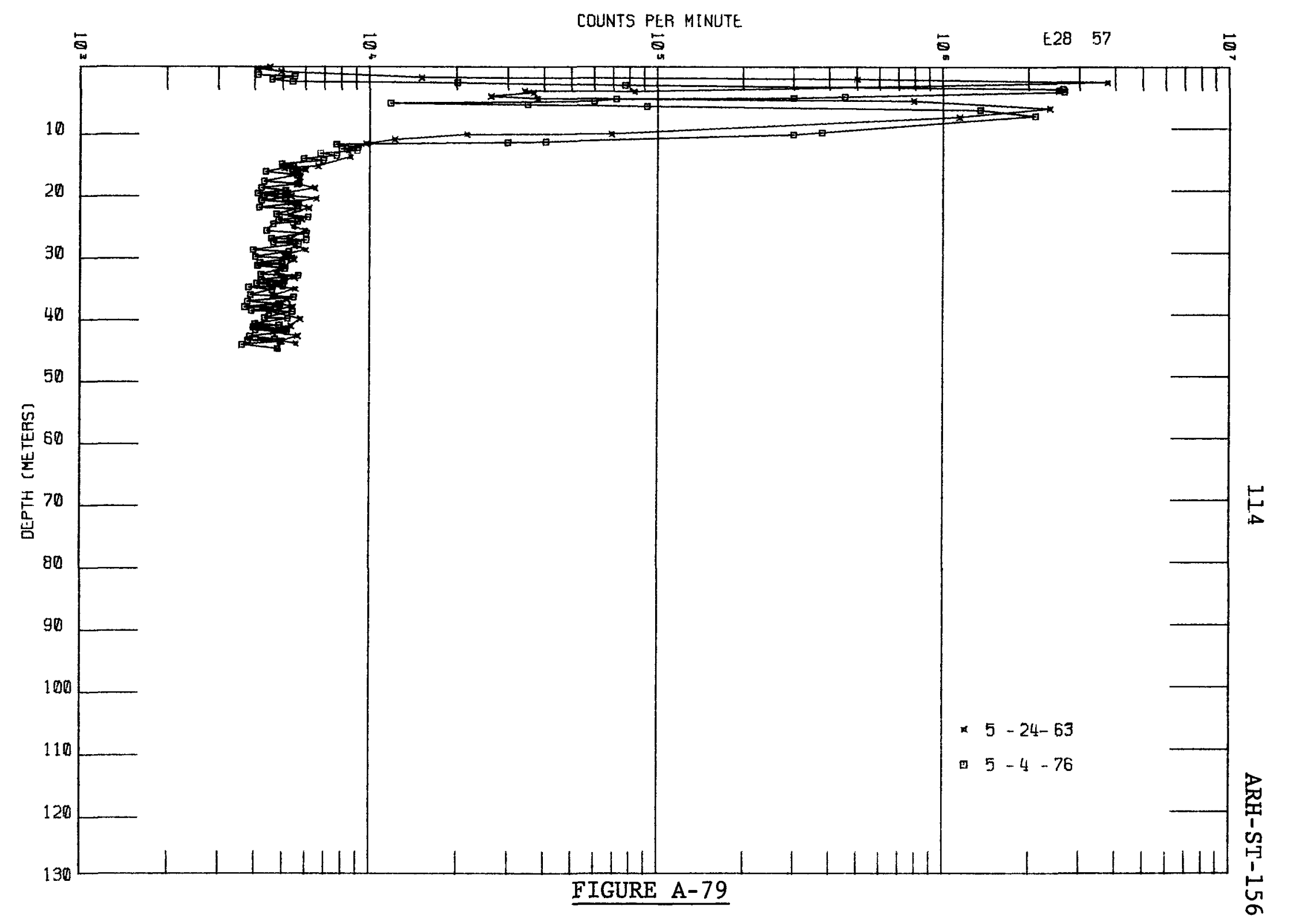

WELL E28-57 SCINTILLATION PROBE PROFILES 


\section{6-B-9 Crib and Tile Field}

Description of Waste: Cell drainage and other liquid waste via Tank $5-6$ in $227-B$.

Service Dates: 1948 to 1951.

Waste Volume: $3.60 \times 10^{7}$ liters

Waste Inventory:

\begin{tabular}{ccc} 
& Total & Decayed Thru June 1976 \\
\cline { 2 - 3 } $\mathrm{Pu}, \mathrm{g}$ & $1.74 \times 10^{2}$ & $1.74 \times 10^{2}$ \\
${ }^{\text {Beta, }} \mathrm{Ci}$ & $7.80 \times 10^{3}$ & $2.84 \times 10^{1}$ \\
${ }^{90} \mathrm{Sr}, \mathrm{Ci}$ & $1.50 \times 10^{7}$ & $7.84 \times 10^{0}$ \\
${ }^{106} \mathrm{Ru}, \mathrm{Ci}$ & $1.00 \times 10^{2}$ & $1.50 \times 10^{-6}$ \\
${ }^{137} \mathrm{Cs}, \mathrm{Ci}$ & $1.00 \times 10^{1}$ & $5.45 \times 10^{0}$ \\
${ }^{60} \mathrm{Co} . \mathrm{Ci}$ & $1.00 \times 10^{-1}$ & $3.14 \times 10^{-3}$ \\
U, kg & $4.54 \times 10^{1}$ & $4.54 \times 10^{7}$
\end{tabular}

Evaluation of Scintillation Probe Profiles:

We11s E28-53, E2854, E28-55 and E28-61 monitor the 216-B-9 crib. We11s E28-56, E28-57, E28-58, E28-59 and E28-60 monitor the 216-B-9 tile field (figures $A-1$ and $A-74$ ).

Radioactive contaminants detected 1.5 meters above the bottom of the 216-B-9 crib (2.6 meters below the ground surface) increase to maximum radiation intensity 0.5 meters below the crib bottom (figures A-75 and $\mathrm{A}-78)$. The radiation intensity in these wells has decreased only slightly between 1963 and 1976.

The scintillation probe profiles indicate the radioactive effluents primarily were discharged to the secondary lateral immediately south of We11 E28-57 in the 216-B-9 tile field (figure A-79). Radioactive contaminants are detected from the depth of the tile distributor pipe (2.6 meters below the ground surface) to 11.9 meters below the distributor pipe. In 1963 we11s E28-58 and E28-59 showed radioactive contaminants 
at 15.2 and 18.3 meters, respectively, below the distributor pipe (figures $A-80$ and $A-81$ ). In 1976 the radiation intensity at these peaks has decreased to near background presumably by radionuclide decay. Only background activity was detected in wells E28-56 and E28-60 (figures $\mathrm{A}-82$ and $\mathrm{A}-83$ ).

The disposal history of the 216-B-9 crib and tile field is reflected in the scintillation probe data. The $241-B-361$ settling tank had nearly been filled with sludge from the $3.1 \times 10^{6}$ liters of wastes that had passed through the tank to the 216-B-5 reverse we11. Therefore, the 216-B-9 crib system was tied directly into the waste lines and began to serve as both a settling tank and crib. Sludge in the waste rapidly decreased the capacity of the crib. After $4.0 \times 10^{6}$ 1iters had been discharged, the crib became sealed with sludge and waste began to overflow into the tile field in November 1948. The principle function of the crib was now a settling tank for the sludge. The sludge contained radionuclide concentrations significantly greater than the effluent overflowing to the tile field. The scintillation probe profiles bear this out. The profiles from wells adjacent to the crib show higher radiation intensities than profiles from wells in the tile field. The profile from Well E28-57 is an exception, showing radiation intensity similar to the four wells adjacent to the crib.

The radioactive contaminants are held high in the soil column beneath the crib. On the basis of the scintillation probe profiles no measurable migration of radionuclides beneath the 216-B-9 crib and tile field can be detected between 1963 and 1976. The slow rate of decay in the profiles from the cribs wells is attributed to higher concentrations of radionuclides and the retention of long lived radionuclides beneath the crib. These data indicate breakthrough to the groundwater has not occurred at this site. 


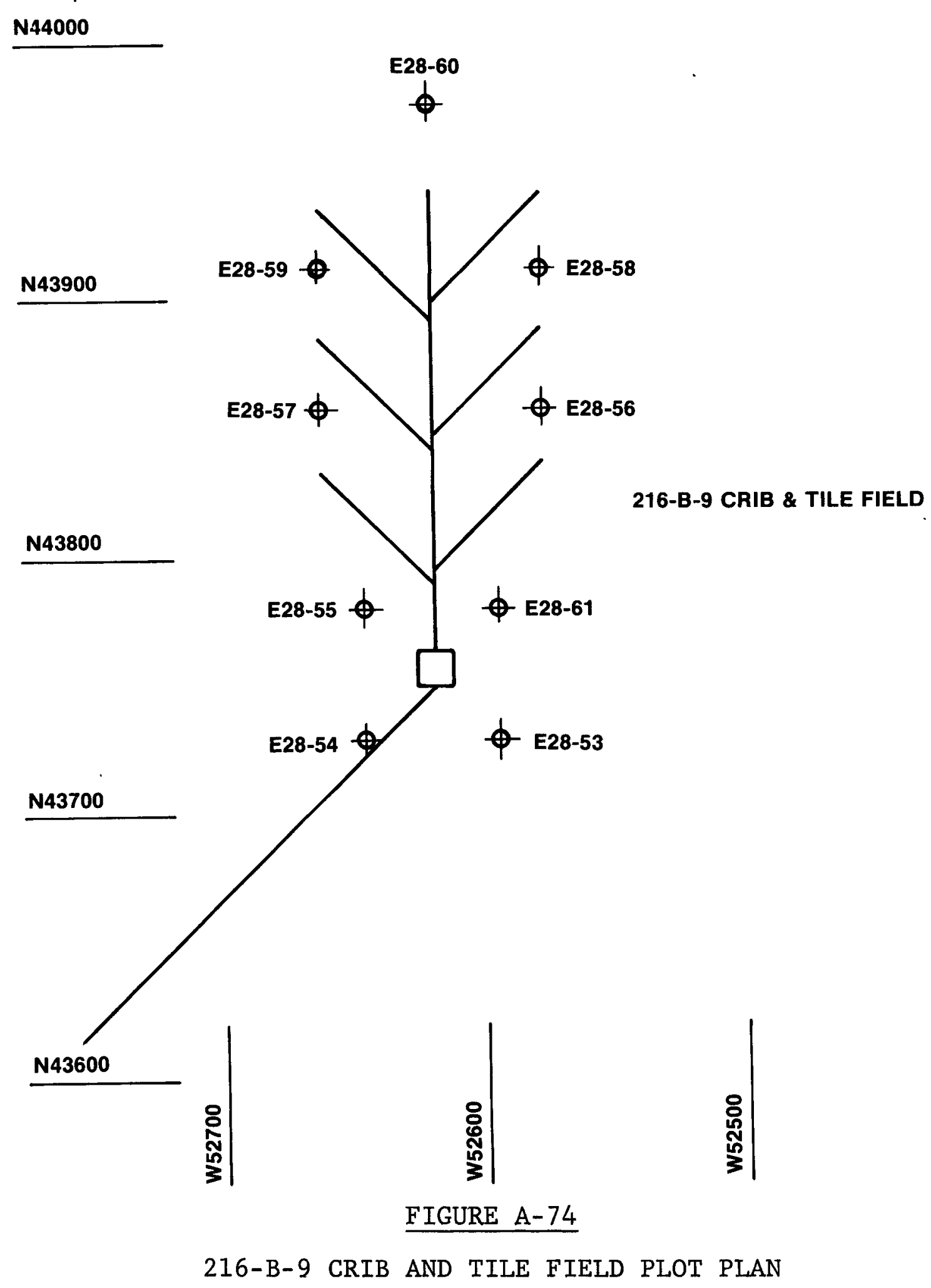




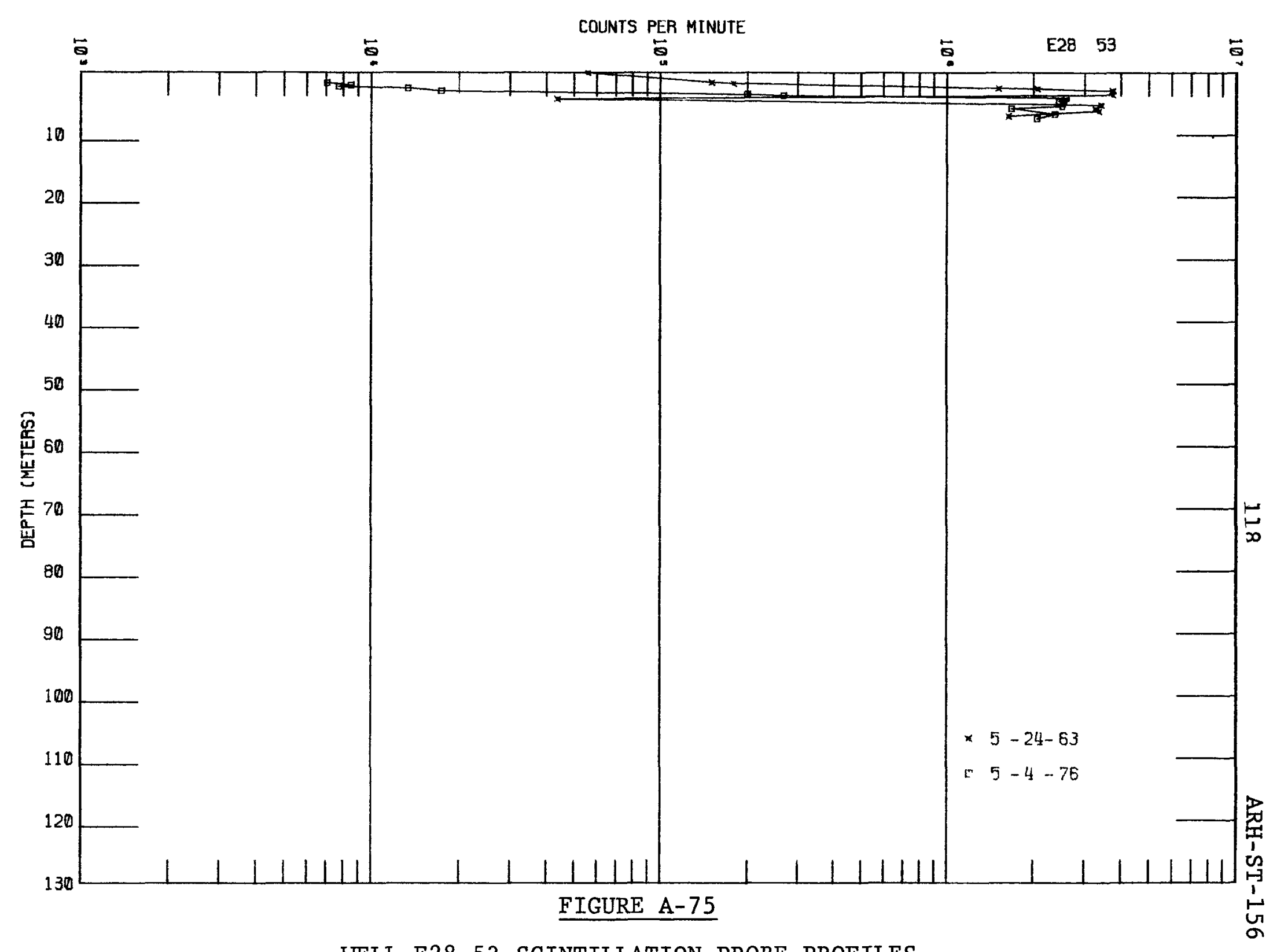

WELL E28-53 SCINTILLATION PROBE PROFILES 
$O \times$

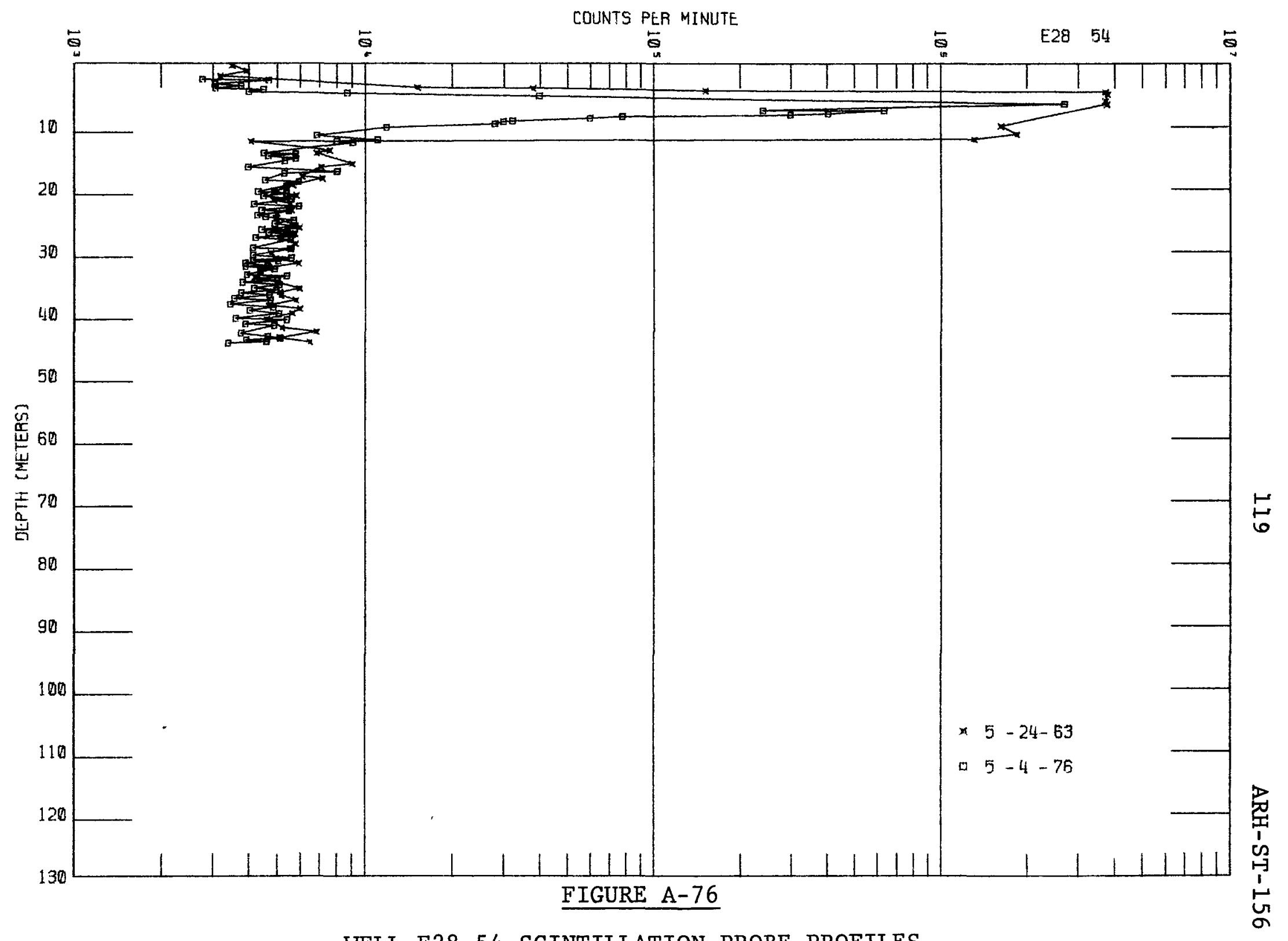

WELL E28-54 SCINTILLATION PROBE PROFILES 
- .

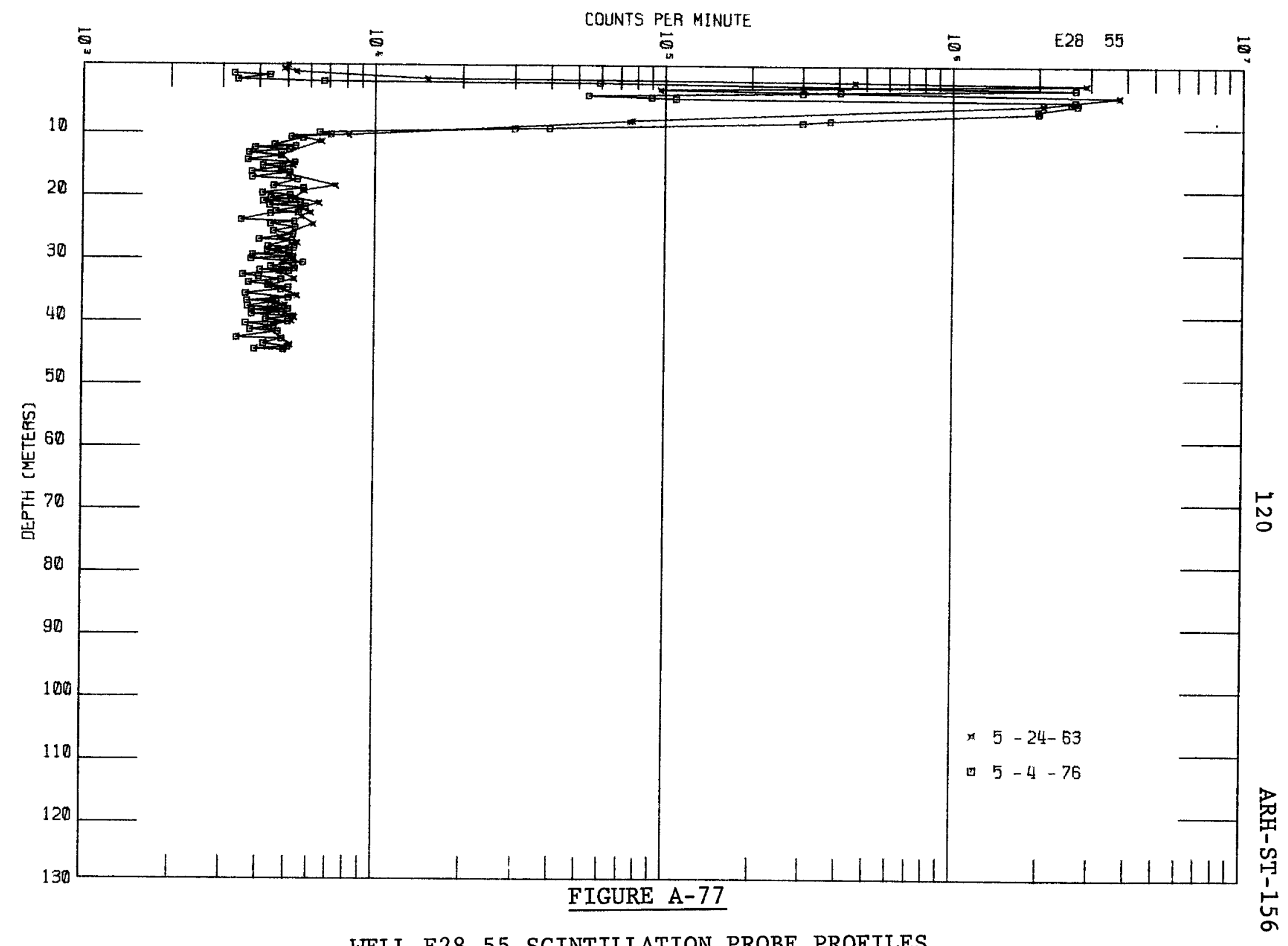

WELL E28-55 SCINTILLATION PROBE PROFILES 
C,

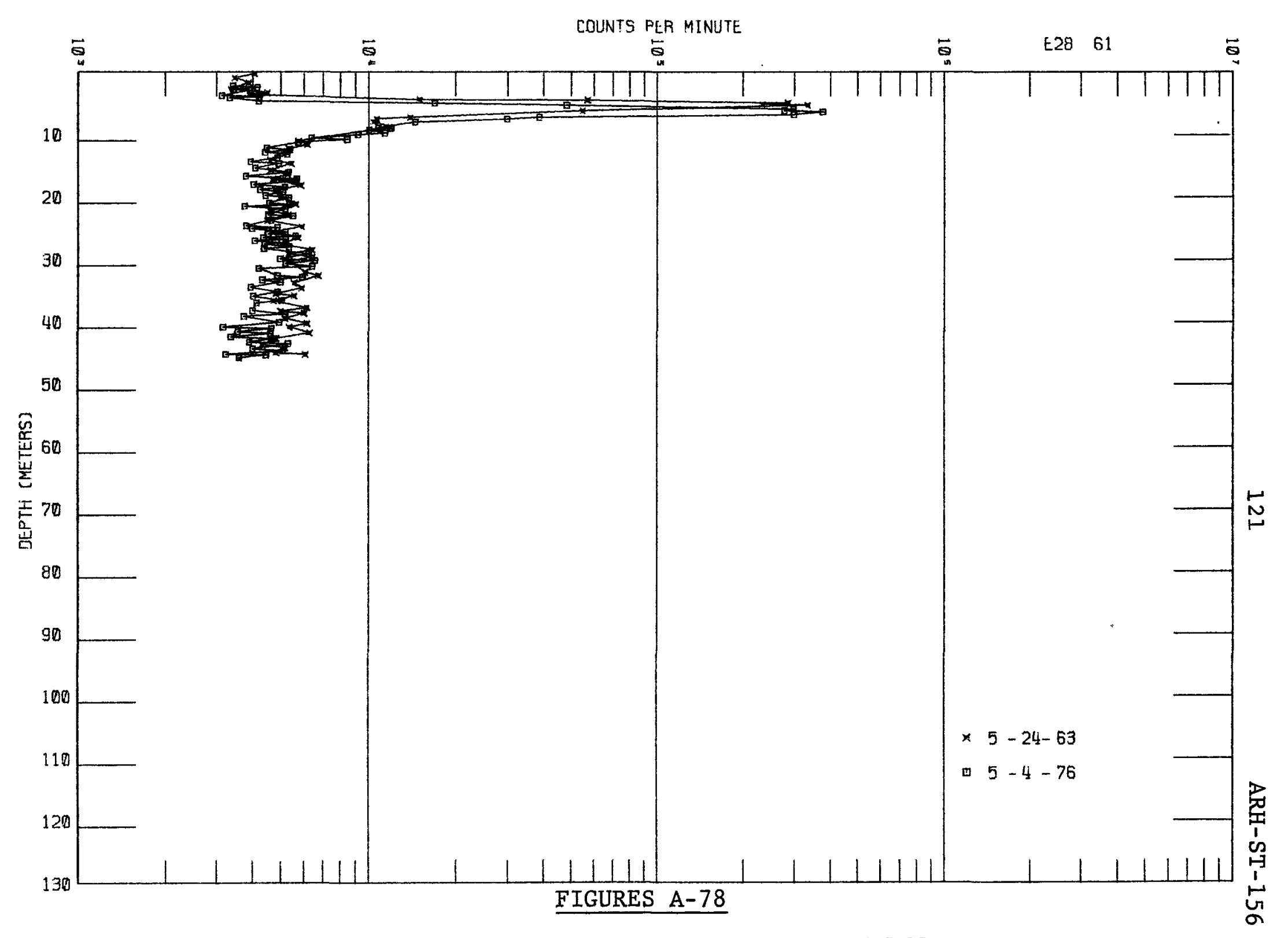

WELL E28-61 SCINTILLATION PROBE PROFILES 


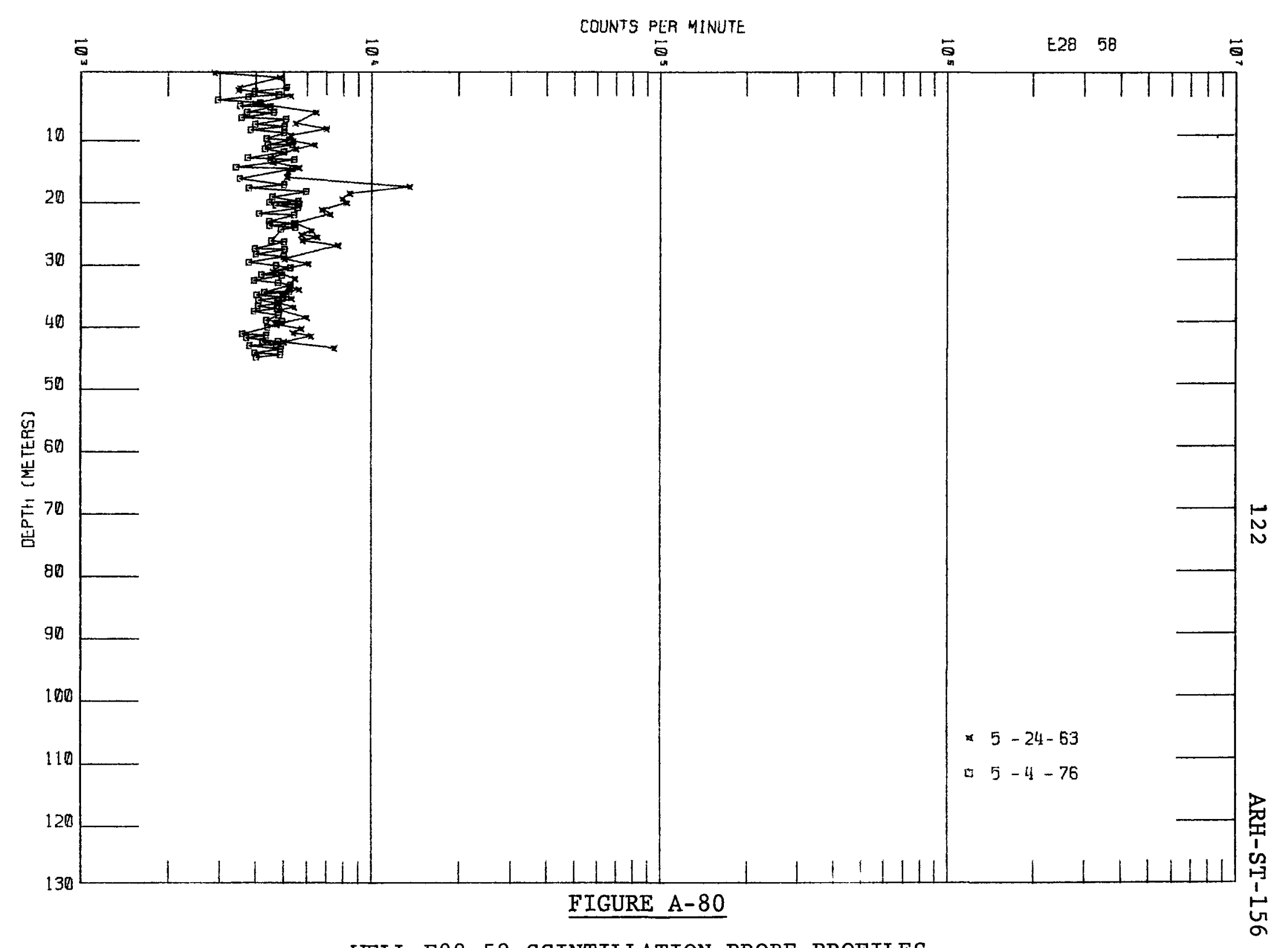

WELL E28-58 SCINTILLATION PROBE PROFILES 


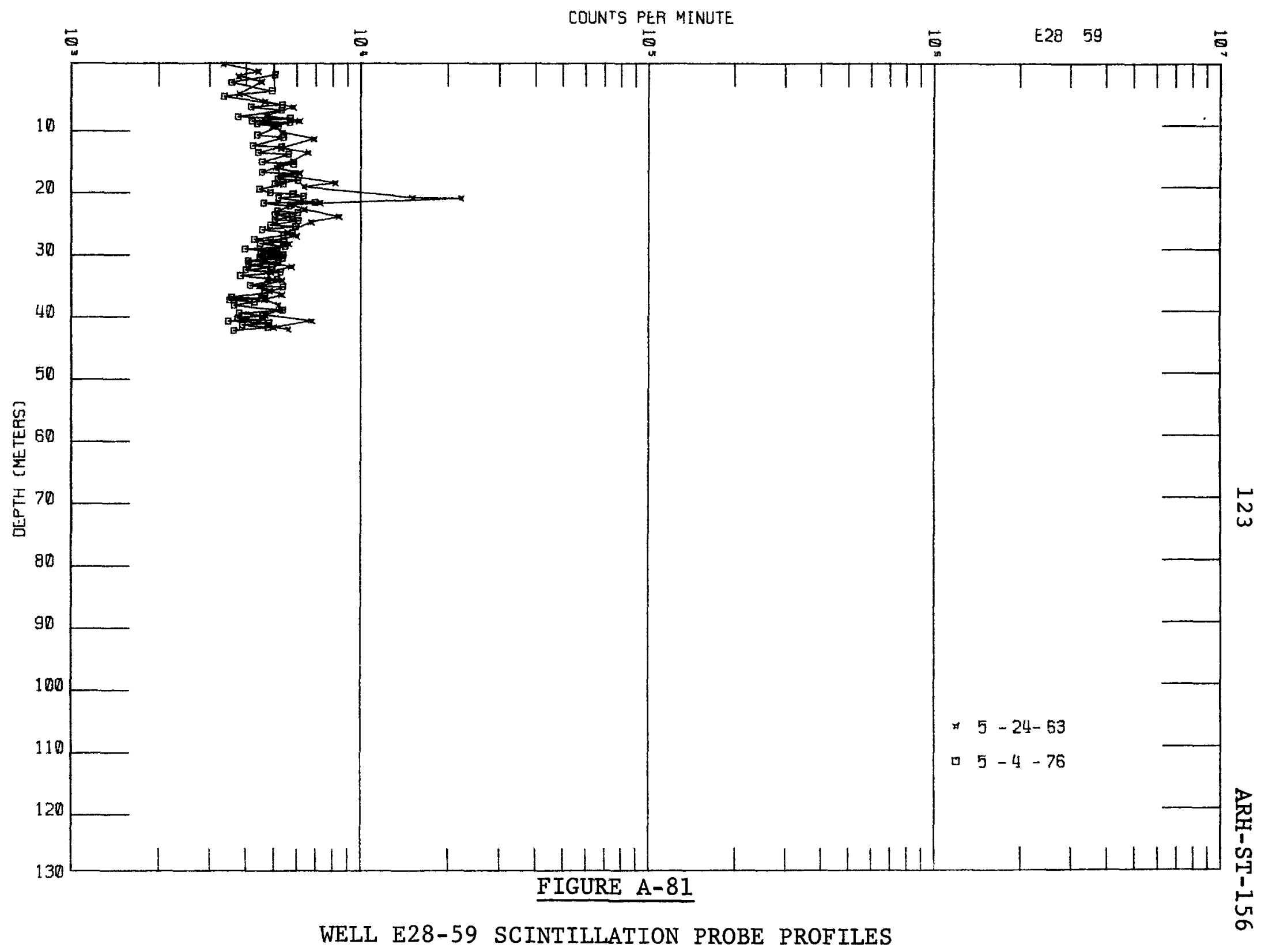




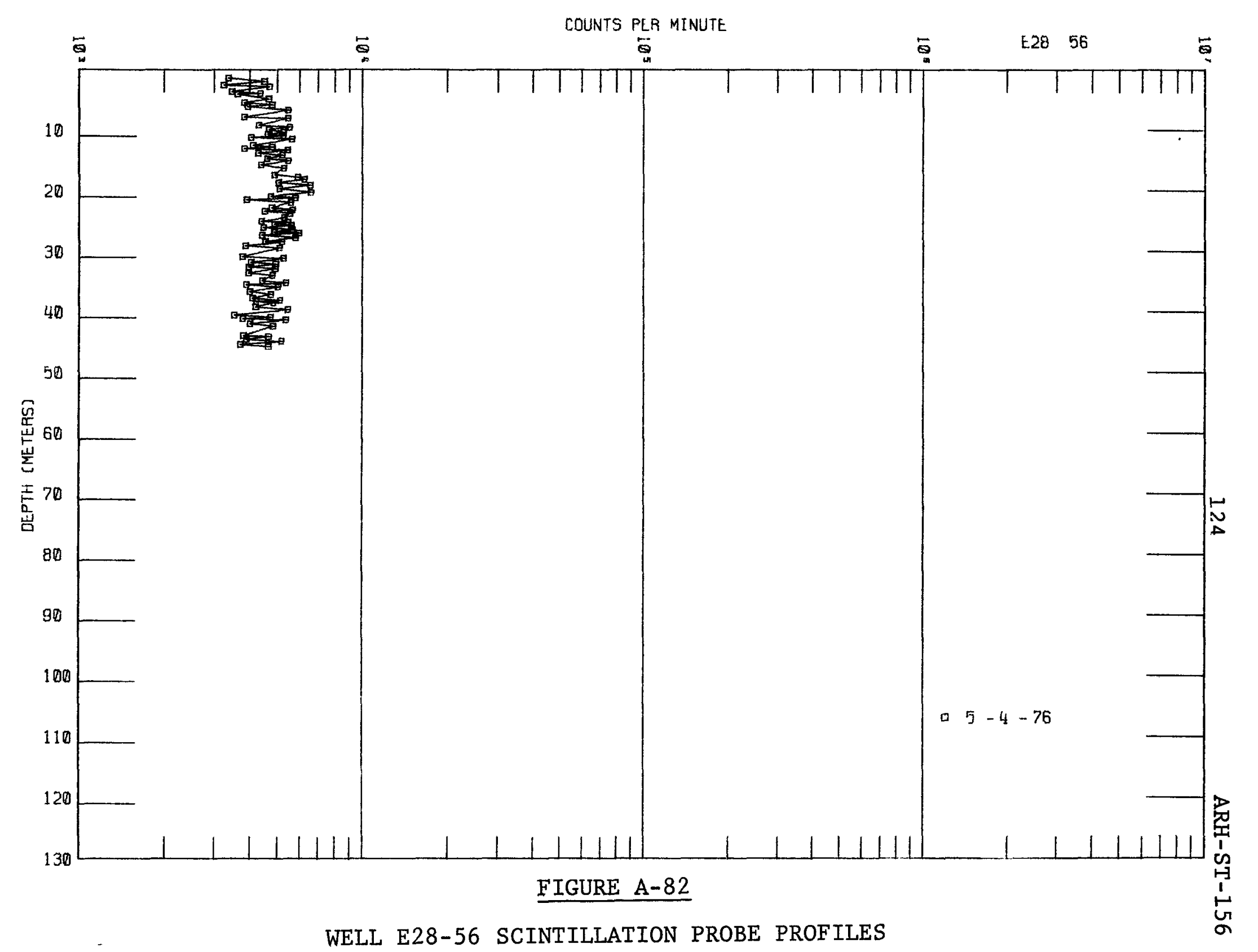




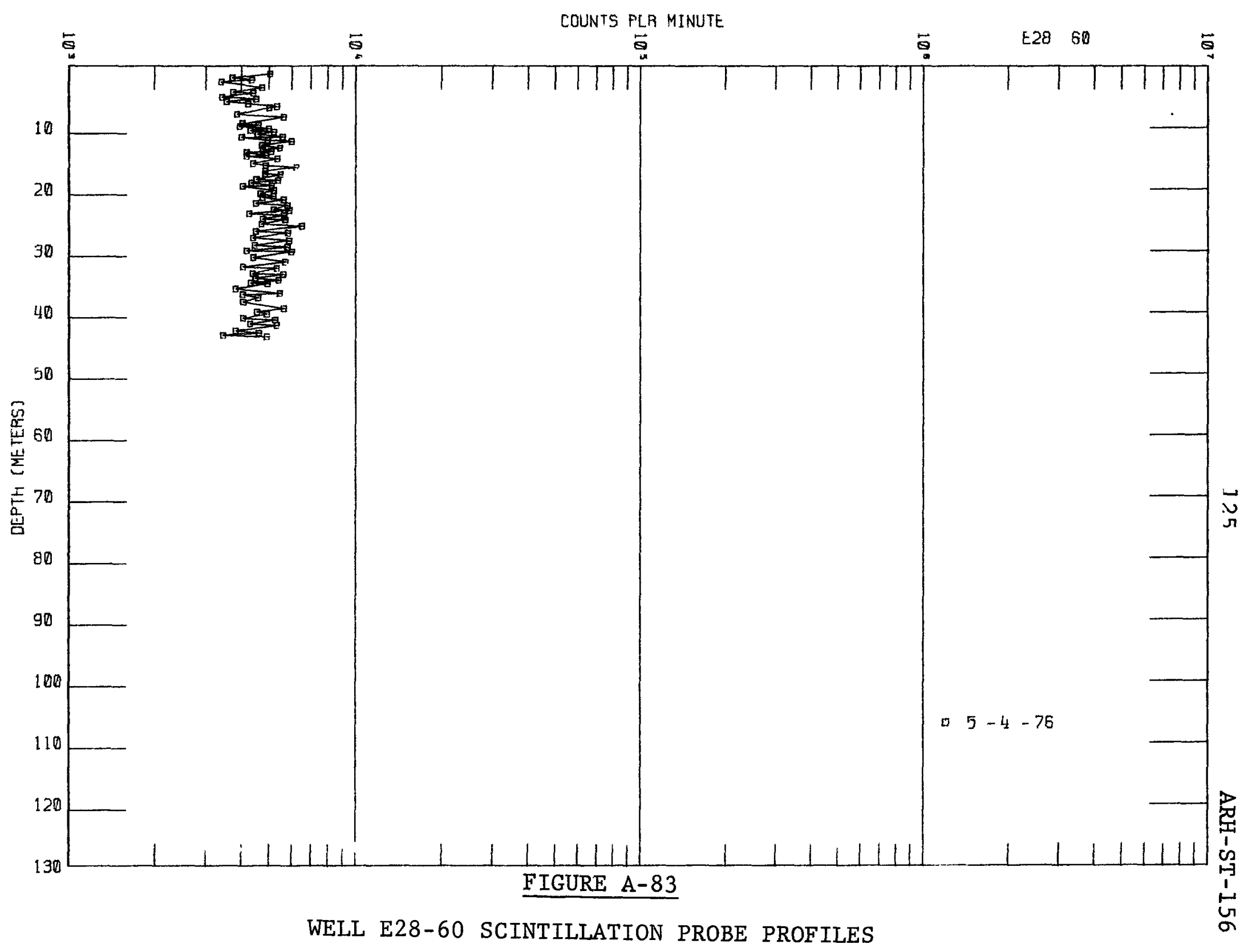




\section{6-B-10A and 10B Cribs}

Description of Waste: Decontamination sink and sample slurper waste from 222-B Laboratory, floor drainage from 292-B Building, and decontamination sink and shower waste from 221-B.

Service Dates: 1949 to 1952 and 1969 to 1973

Waste Volume: $1.00 \times 10^{7}$ 1iters

Waste Inventory:

\begin{tabular}{ccc} 
& Total & Decayed Thru June 1976 \\
\cline { 2 - 3 } $\mathrm{Pu}, \mathrm{g}$ & $9.80 \times 10^{0}$ & $9.80 \times 10^{0}$ \\
${ }^{\mathrm{Beta}, \mathrm{Ci}}$ & $5.00 \times 10^{1}$ & $6.43 \times 10^{0}$ \\
${ }^{90} \mathrm{Sr}, \mathrm{Ci}$ & $5.00 \times 10^{0}$ & $2.68 \times 10^{1}$ \\
${ }^{106} \mathrm{Ru}, \mathrm{Ci}$ & $1.00 \times 10^{7}$ & $3.29 \times 10^{-7}$ \\
${ }^{137} \mathrm{Cs}, \mathrm{Ci}$ & $1.00 \times 10^{0}$ & $5.56 \times 10^{-1}$ \\
${ }^{60} \mathrm{Co}, \mathrm{Ci}$ & $1.00 \times 10^{-1}$ & $3.49 \times 10^{-3}$ \\
$\mathrm{U}, \mathrm{kg}$ & $9.07 \times 10^{0}$ & $9.07 \times 10^{0}$
\end{tabular}

Evaluation of Scintillation Probe Profiles:

We11 E28-17 monitors the 216-B-10A and 10B cribs (figures $A-1$ and $A-84)$. Only background radiation is detected in the monitoring well located 18.3 meters southeast of the 216-A-10A crib (figure A-85). Based on the total volume and total radioactive effluents discharged to these cribs breakthrough to the groundwater has not occurred at this site. 
N42400

N42300

N42200

N42100
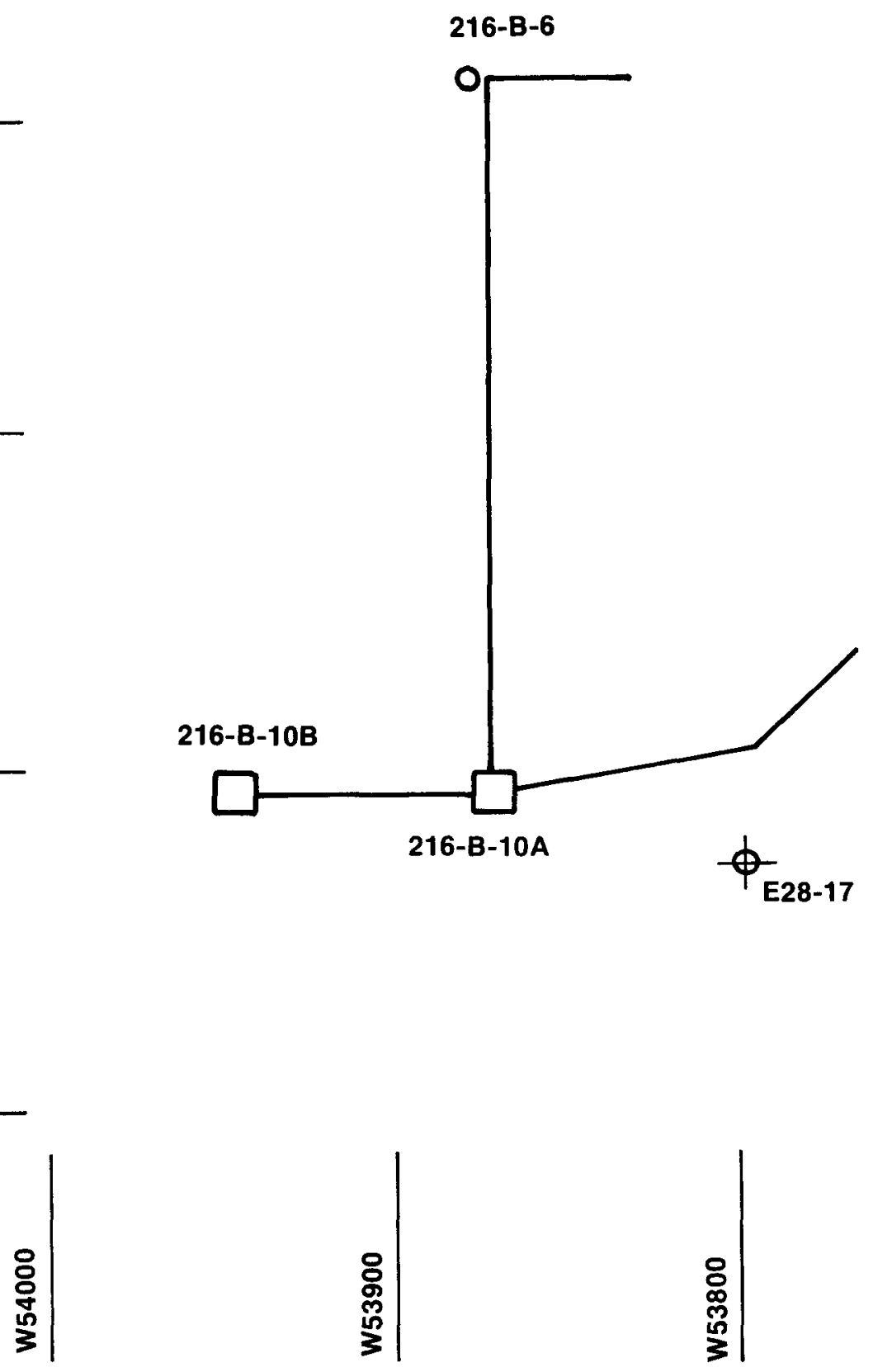

FIGURE A-84

216-A-6 AND 216-A-10A AND 10B CRIB PLOT PLANS 
+

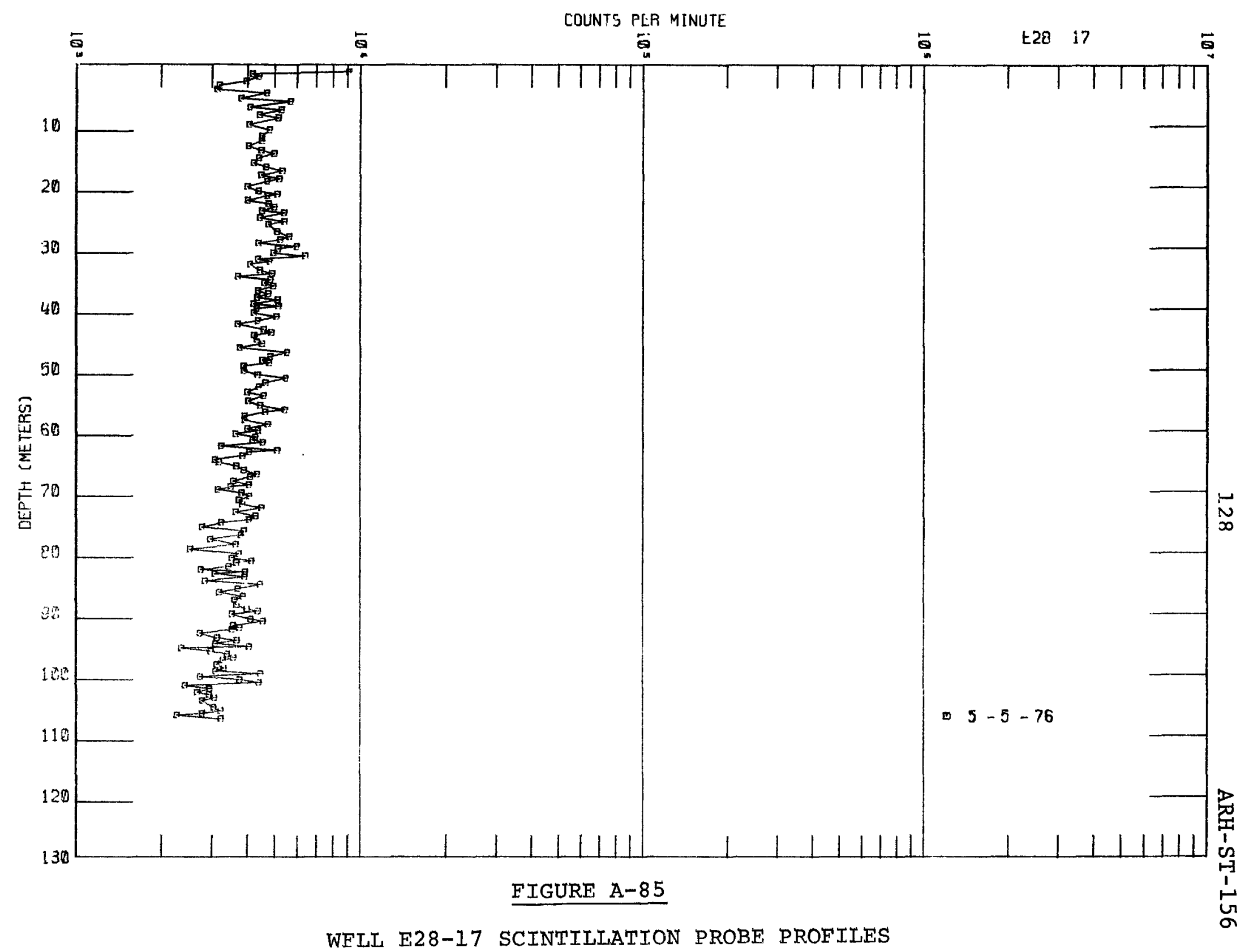


216-B-11A and 11B Reverse Wel1s

Description of Waste: Process condensate from the 242-B evaporator

Service Dates: 1952 to 1954

Waste Volume: $2.96 \times 10^{7}$ Titers

Waste Inventory:

\begin{tabular}{ccc} 
& Total & Decayed Thru June 1976 \\
\cline { 2 - 3 } $\mathrm{Pu}, \mathrm{g}$ & $4.00 \times 10^{0}$ & $4.00 \times 10^{0}$ \\
${ }^{\text {Beta, }} \mathrm{Ci}$ & $2.11 \times 10^{2}$ & $6.25 \times 10^{1}$ \\
${ }^{90} \mathrm{Sr}, \mathrm{Ci}$ & $5.00 \times 10^{0}$ & $2.85 \times 10^{0}$ \\
${ }^{106} \mathrm{Ru}, \mathrm{Ci}$ & $5.00 \times 10^{1}$ & $7.92 \times 10^{-6}$ \\
${ }^{137} \mathrm{Cs}, \mathrm{Ci}$ & $5.00 \times 10^{7}$ & $2.96 \times 10^{1}$ \\
${ }^{60} \mathrm{Co}, \mathrm{Ci}$ & $1.00 \times 10^{-1}$ & $5.02 \times 10^{-3}$ \\
$\mathrm{U}, \mathrm{Kg}$ & $1.36 \times 10^{1}$ & $1.36 \times 10^{1}$
\end{tabular}

\section{Evaluation of Scintillation Probe Profiles:}

We11s E33-20 and E33-19 monitor the 216-B-11A and 216-B-11B reverse wells, respectfully (figures $A-1$ and $A-56$ ). Radioactive contaminants are detected 22.9 meters below the ground surface in Well E33-20 and 27.4 meters below the ground surface in Well E33-19 (figures A-86 and $A-87)$. The radiation intensity has been decreasing with time due to radionuclide decay.

On the basis of the scintillation probe profiles no measurable migration of radionuclides beneath the 216-B-11A and $11 \mathrm{~B}$ reverse wells has been detected. These data indicate breakthrough to the groundwater has not occurred at this site. 


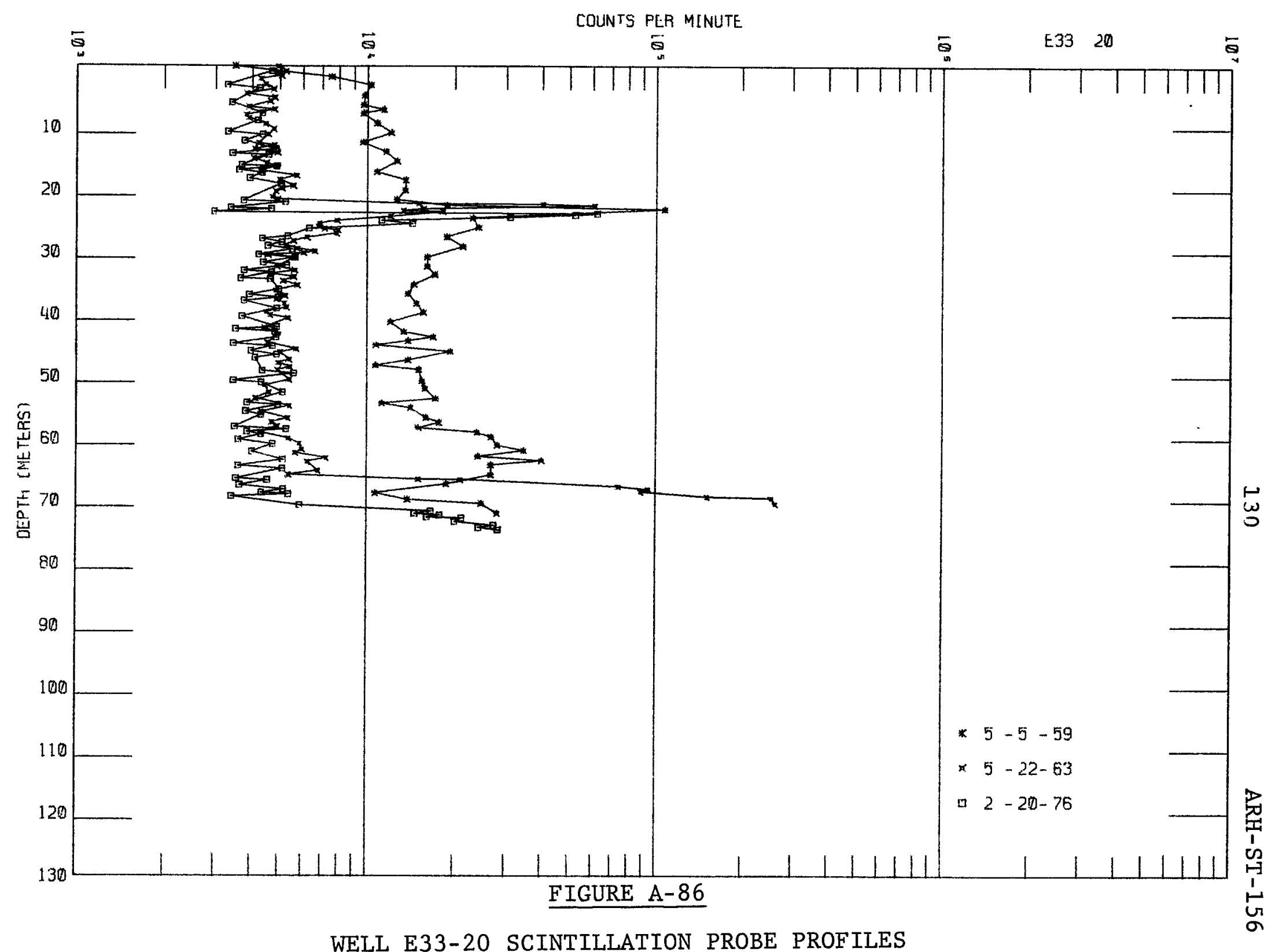

WELL E33-20 SCINTILLATION PROBE PROFILES 


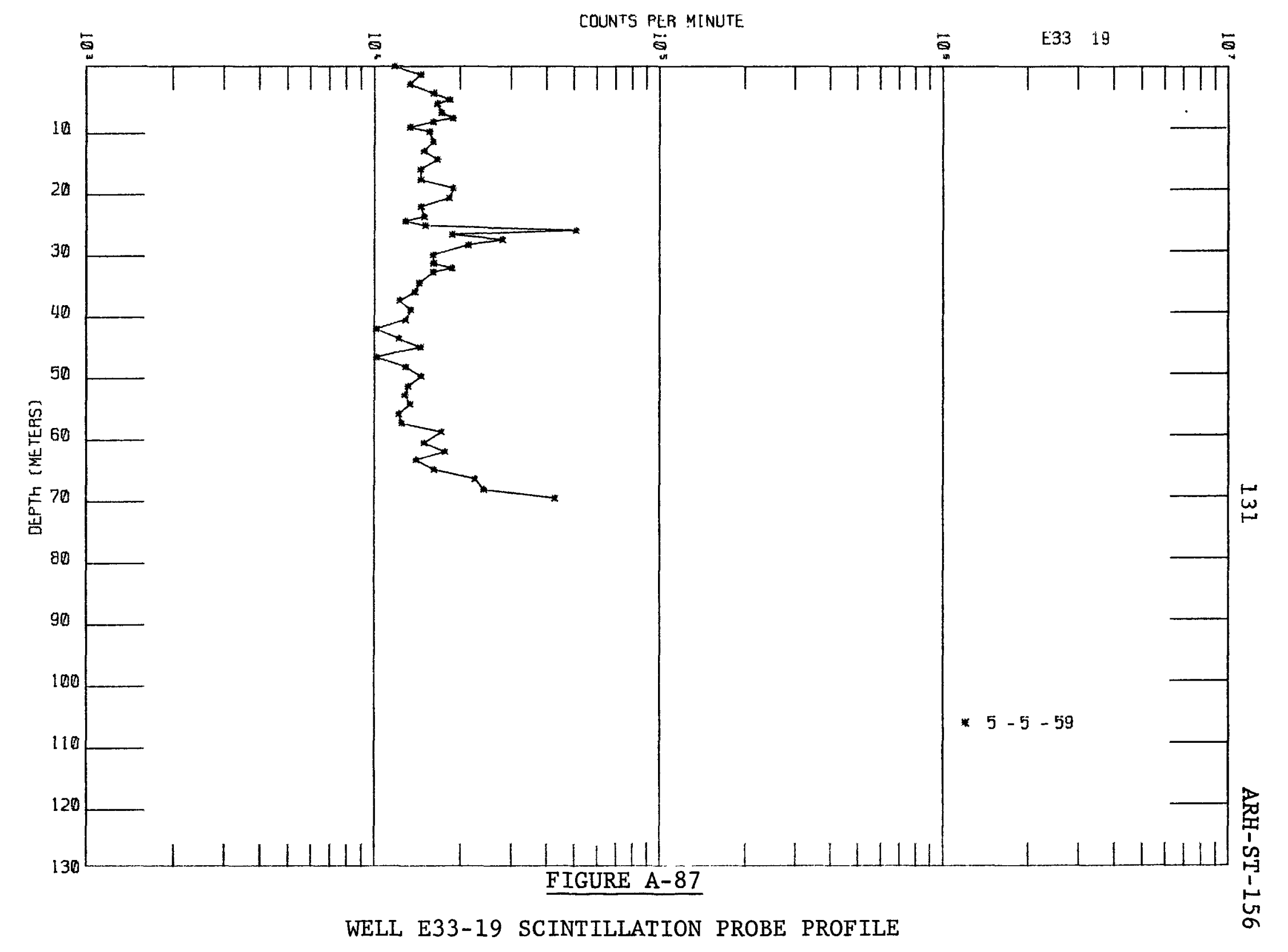


Description of Waste: Process condensate from evaporators in 221- $U$ and 224-U, construction waste and 221-B process condensate neutralized with limestone.

Service Dates: 1952 to 1957 and 1967 to 1973

Waste Volume: $5.20 \times 10^{8}$ liters

Waste Inventory:

\begin{tabular}{|c|c|c|}
\hline & Total & Decayed Thru June 1976 \\
\hline $\mathrm{Pu}, \mathrm{g}$ & $3.74 \times 10^{2}$ & $3.74 \times 10^{2}$ \\
\hline Beta, $\mathrm{C} j$ & $1.12 \times 10^{4}$ & $2.21 \times 10^{3}$ \\
\hline${ }^{90} \mathrm{Sr}, \mathrm{Ci}$ & $<1.53 \times 10^{2}$ & $<1.13 \times 10^{2}$ \\
\hline${ }^{106} \mathrm{Ru}, \mathrm{Ci}$ & $3.11 \times 10^{2}$ & $1.10 \times 10^{0}$ \\
\hline${ }^{137} \mathrm{Cs}, \mathrm{Ci}$ & $1.20 \times 10^{3}$ & $9.94 \times 10^{2}$ \\
\hline${ }^{60} \mathrm{Co}, \mathrm{Ci}$ & $<1.73 \times 10^{0}$ & $<8.17 \times 10^{-1}$ \\
\hline $\mathrm{U}, \mathrm{kg}$ & $2.09 \times 10^{4}$ & $2.09 \times 10^{4}$ \\
\hline
\end{tabular}

Evaluation of Scintillation Probe Profiles:

We11s E28-9, E28-16, E28-64, E28-65 and E28-66 monitor the 216-B-12 crib (figures $A-1$ and A-88). We11s E28-64, E28-65 and E28-66 are shallow monitoring structures that monitor sections 1,2 and 3 of the crib respectfully. Radioactive contaminants are detected in sections 1 and 2, 3.0 meters below the ground surface and in section 3, 7.0 meters below the ground surface (figures A-89, A-90 and A-91). Maximum radiation intensity occurs from the base of the crib (10 meters below the ground surface) to at least 10.4 meters beneath the crib. These shallow monitoring wells do not fully penetrate the zone of contamination. Well E28-16 shows radioactive contaminants occurring 14.1 to 18.0 meters below the bottom of the crib (figure A-92). Only background radiation is detected in Well E28-9 (figure A-93).

The radiation intensity increased from 1968 to 1976 at the bottom of wells E28-65 and E28-66. This increase is probably due to waste discharged to the 216-B-12 crib from 1967 to 1973. The scintillation probe data indicate that breakthrough to the groundwater has not occurred at this site. 
216-B-12

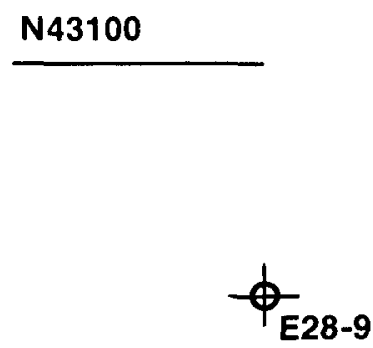

N43000

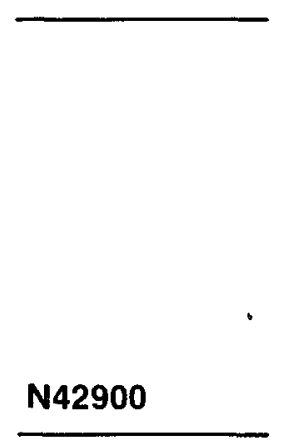

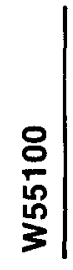
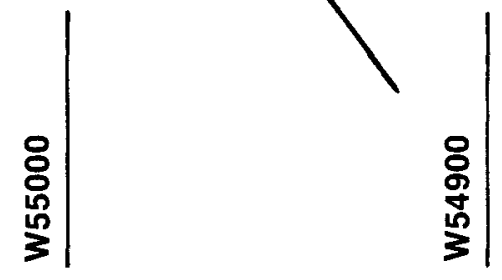

FIGURE A-88 
COUNTS PLR MINUTE

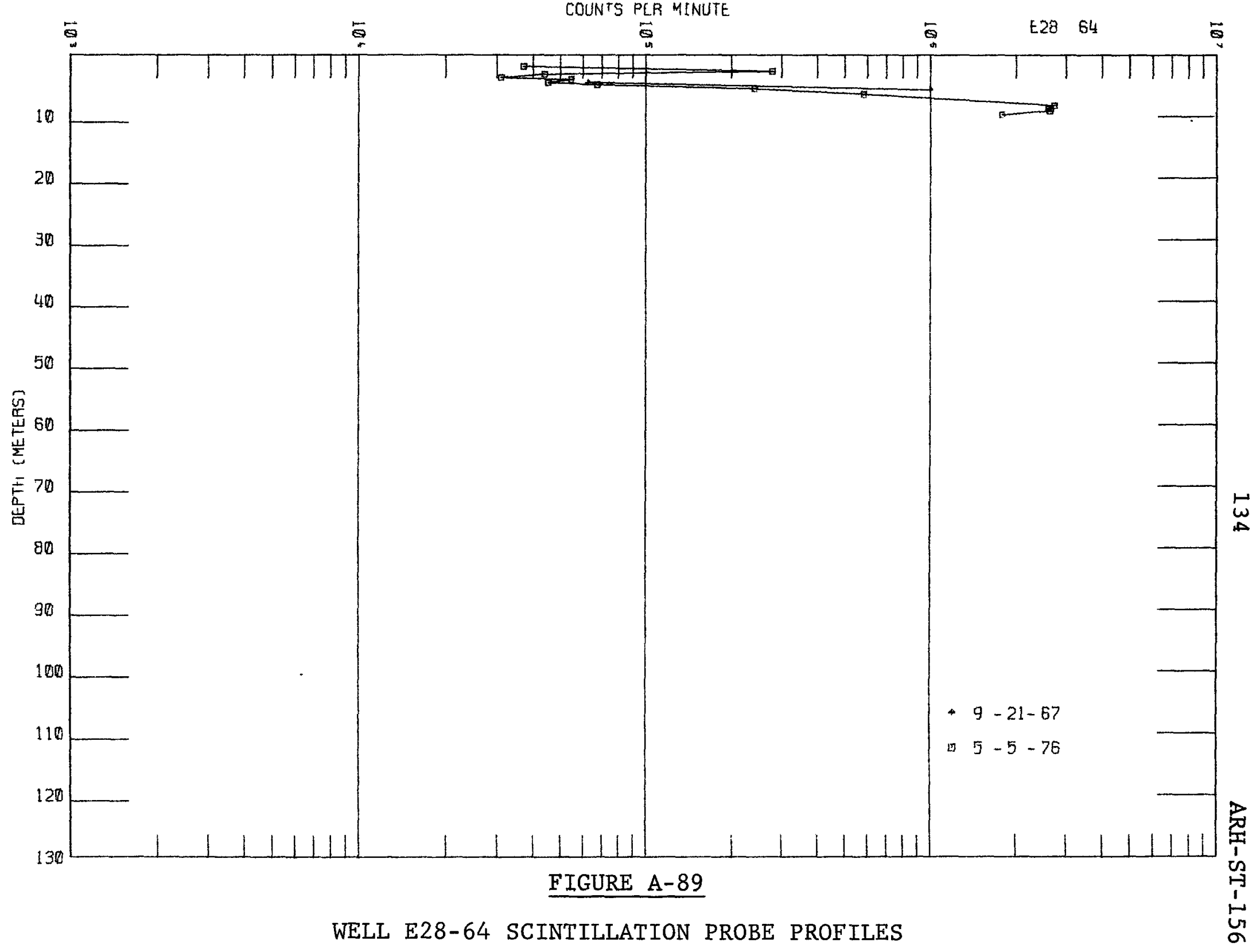


O. -

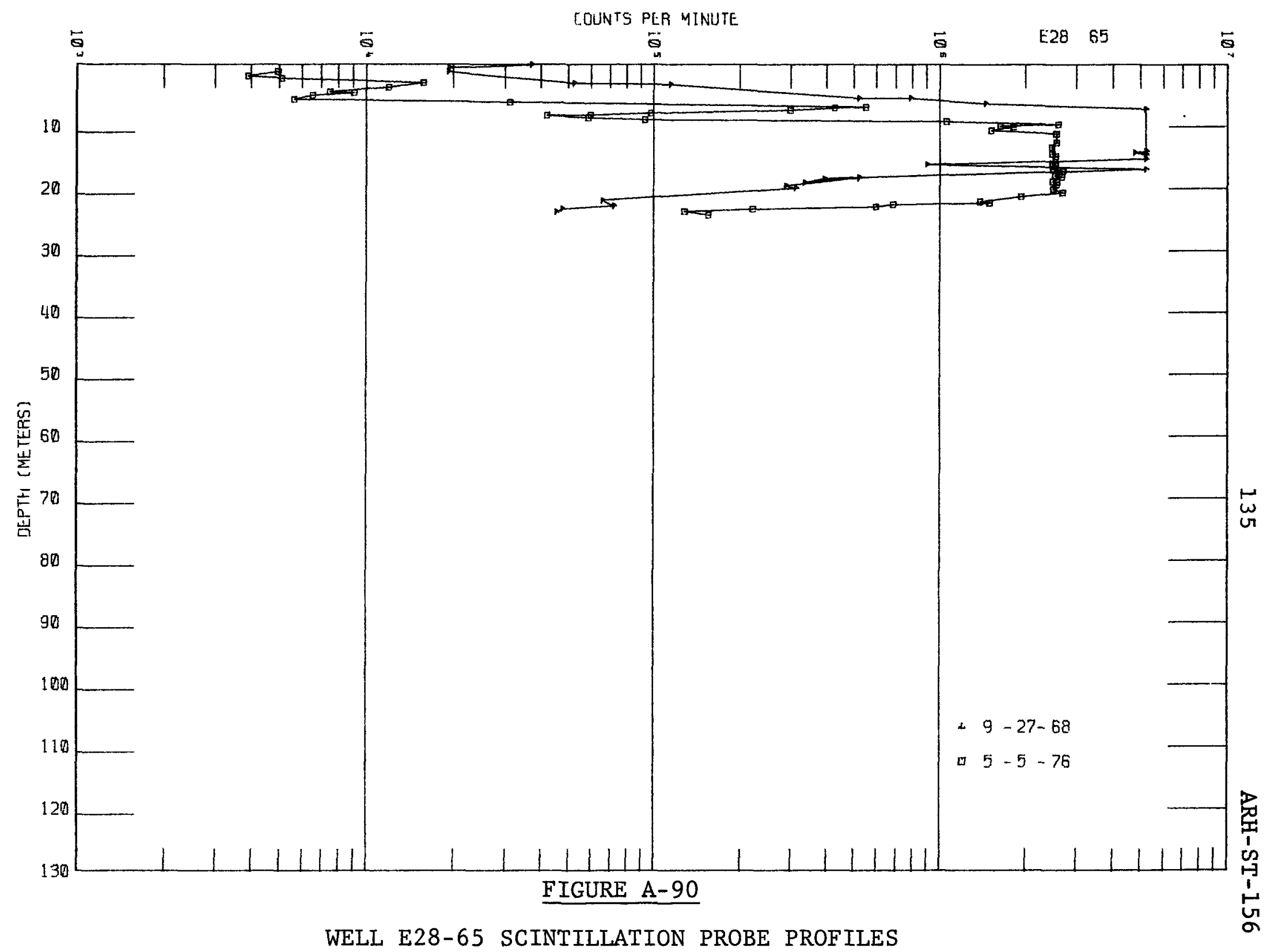


C.

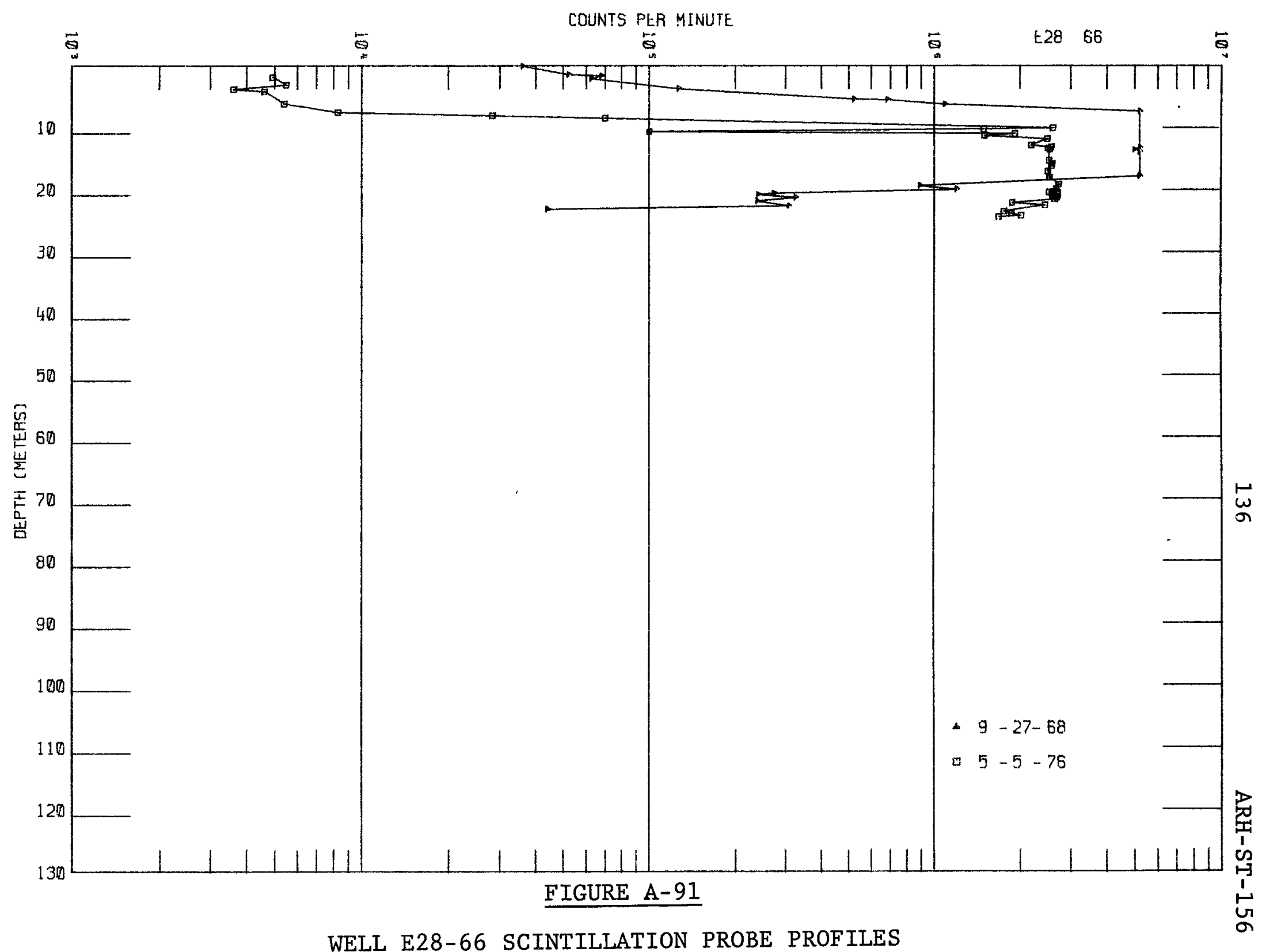




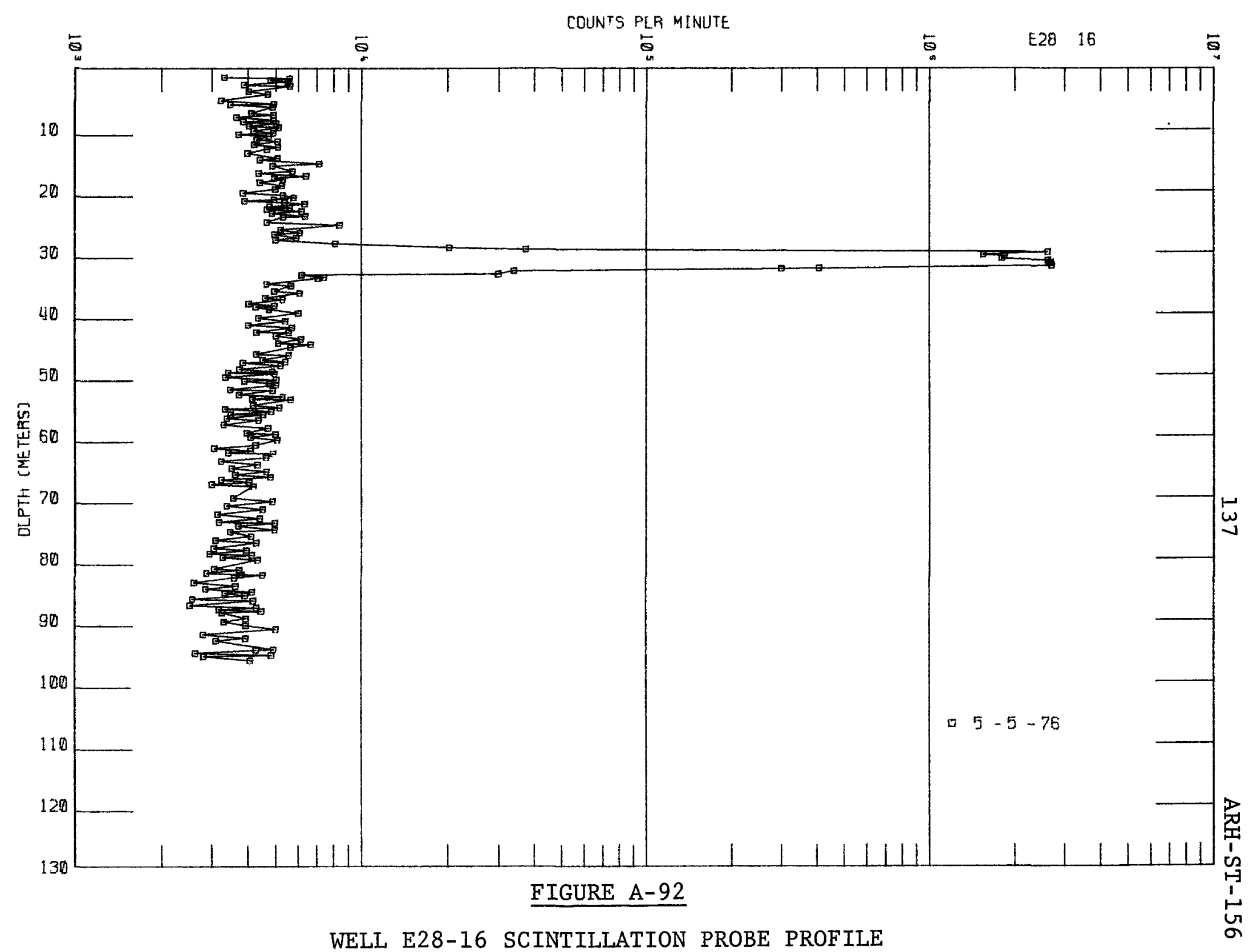


C 3

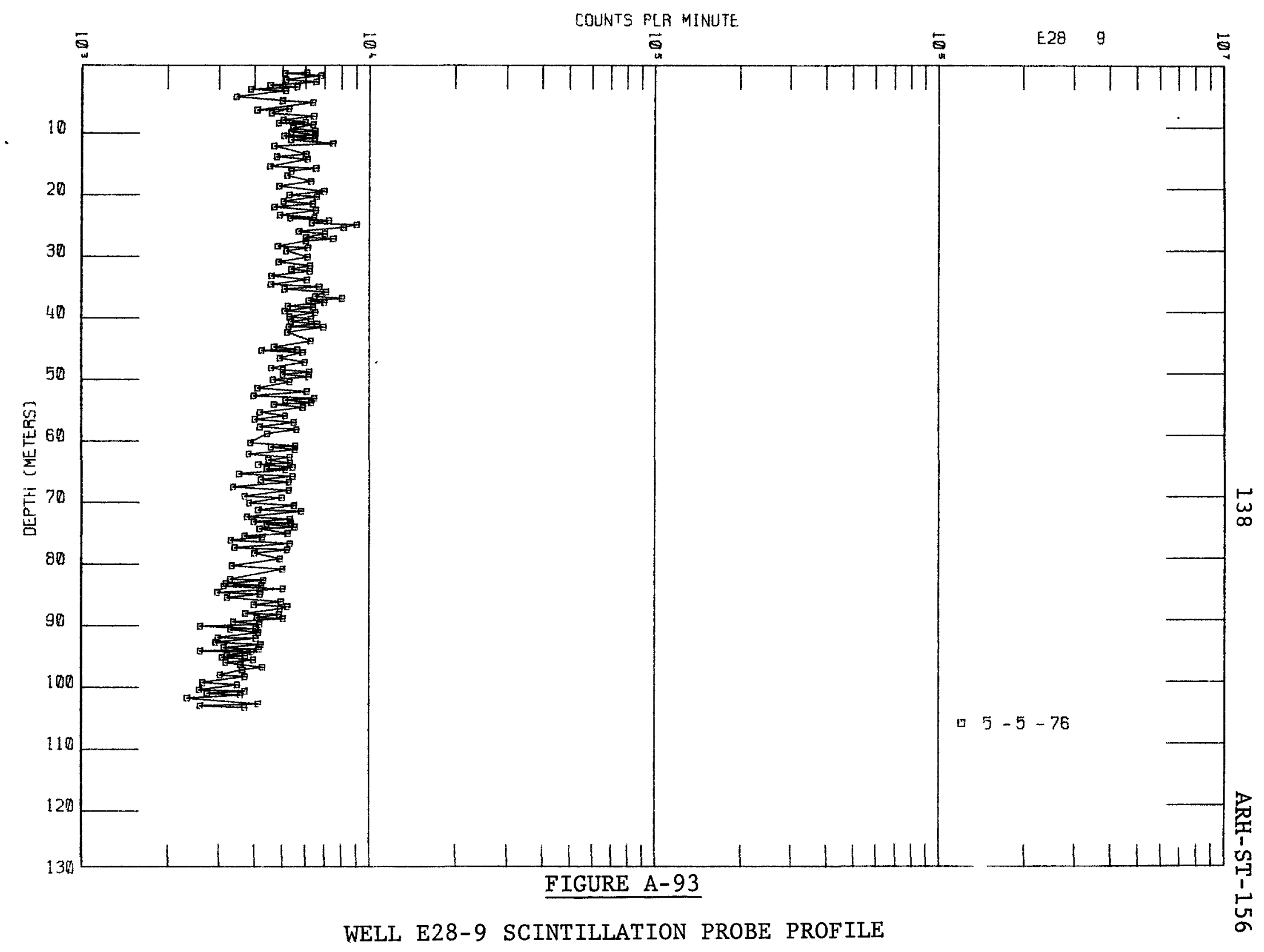


Description of Waste: Scavenged waste from uranium recovery (TBP solvent extraction) process in 221-U Building.

Service Dates: 1956

Waste Volume: $8.71 \times 10^{6}$ liters

Waste Inventory:

\begin{tabular}{|c|c|c|}
\hline & Total & Decayed Thru June 1976 \\
\hline $\mathrm{Pu}, \mathrm{g}$ & $2.50 \times 10^{1}$ & $2.50 \times 10^{1}$ \\
\hline Beta, Ci & $1.40 \times 10^{5}$ & $8.07 \times 10^{2}$ \\
\hline${ }^{90} \mathrm{Sr}, \mathrm{Ci}$ & $4.00 \times 10^{2}$ & $2.45 \times 10^{2}$ \\
\hline${ }^{106} \mathrm{Ru}, \mathrm{Ci}$ & $5.90 \times 10^{4}$ & $6.03 \times 10^{-2}$ \\
\hline${ }^{137} \mathrm{Cs}, \mathrm{Ci}$ & $2.50 \times 10^{2}$ & $1.58 \times 10^{2}$ \\
\hline${ }^{60} \mathrm{Co}, \mathrm{Ci}$ & $5.00 \times 10^{0}$ & $3.58 \times 10^{-1}$ \\
\hline $\mathrm{U}, \mathrm{kg}$ & $2.18 \times 10^{2}$ & $2.18 \times 10^{2}$ \\
\hline
\end{tabular}

Evaluation of Scintillation Probe Profiles;

We11 E13-1 monitors the 216-B- 14 crib (figures $A-1$ and A-94). In 1976 radioactive contaminants are detected between 1.5 and 78.0 meters below the ground surface (figure A-95).

The scintillation probe profiles from 1956, one month after waste disposal to the crib was terminated, thru 1963 show the contaminant front has penetrated an additional 40.6 meters. Since 1963 continued drainage has effectively stopped retaining the contaminants in the sediment column 22.6 meters above the water table. The radiation intensity increased from 1956 to 1959, but since 1959 the intensity has continually decreased due to radionuclide decay. The slow rate of decrease is due to the presence of long-lived radionuclides, principally cesium. These data indicate the possibility of breakthrough to the groundwater from this site. 

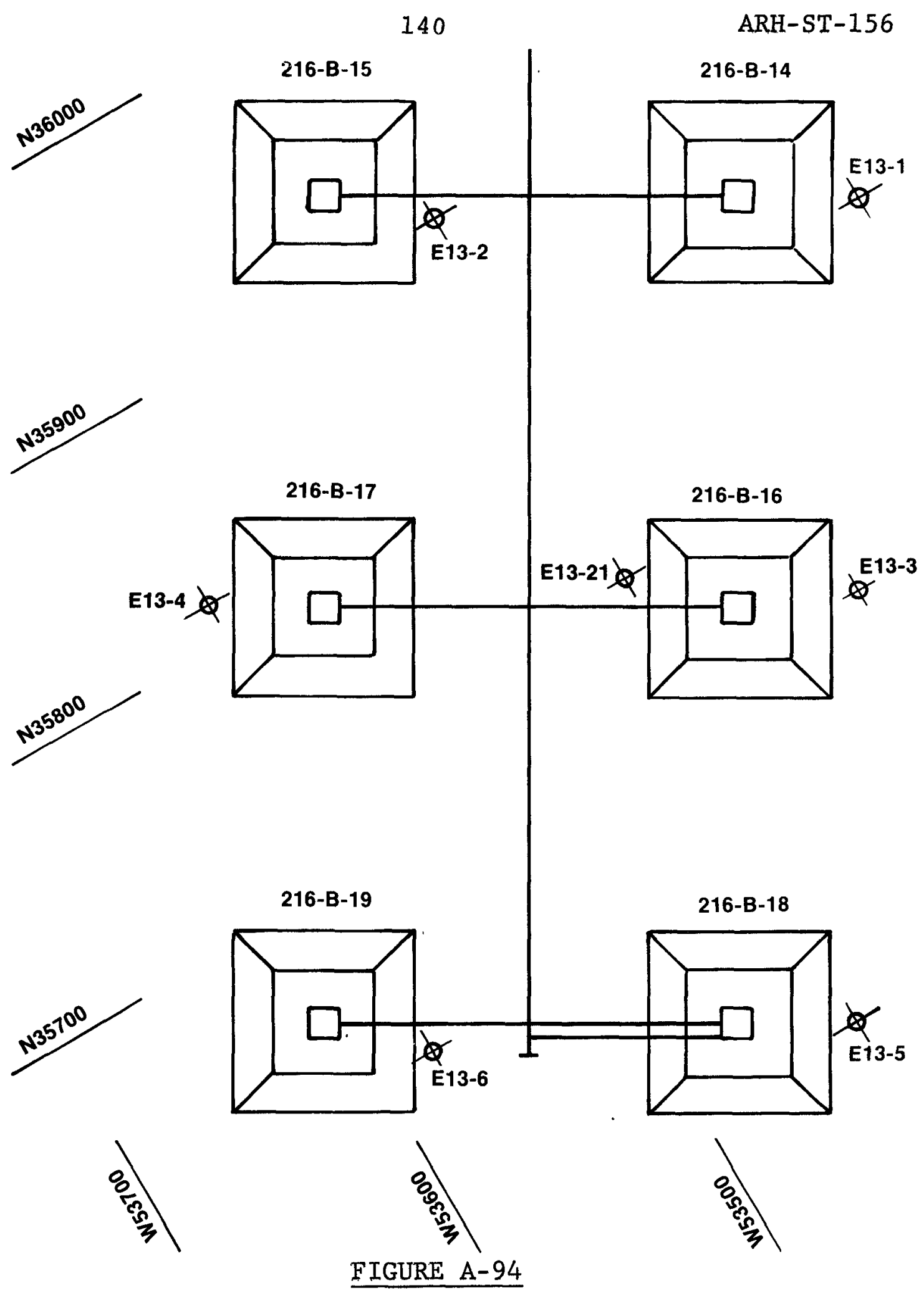

\section{FIGURE A-94}

216-B-14 THROUGH 216-B-19

CRIB PLOT PLANS 
0.

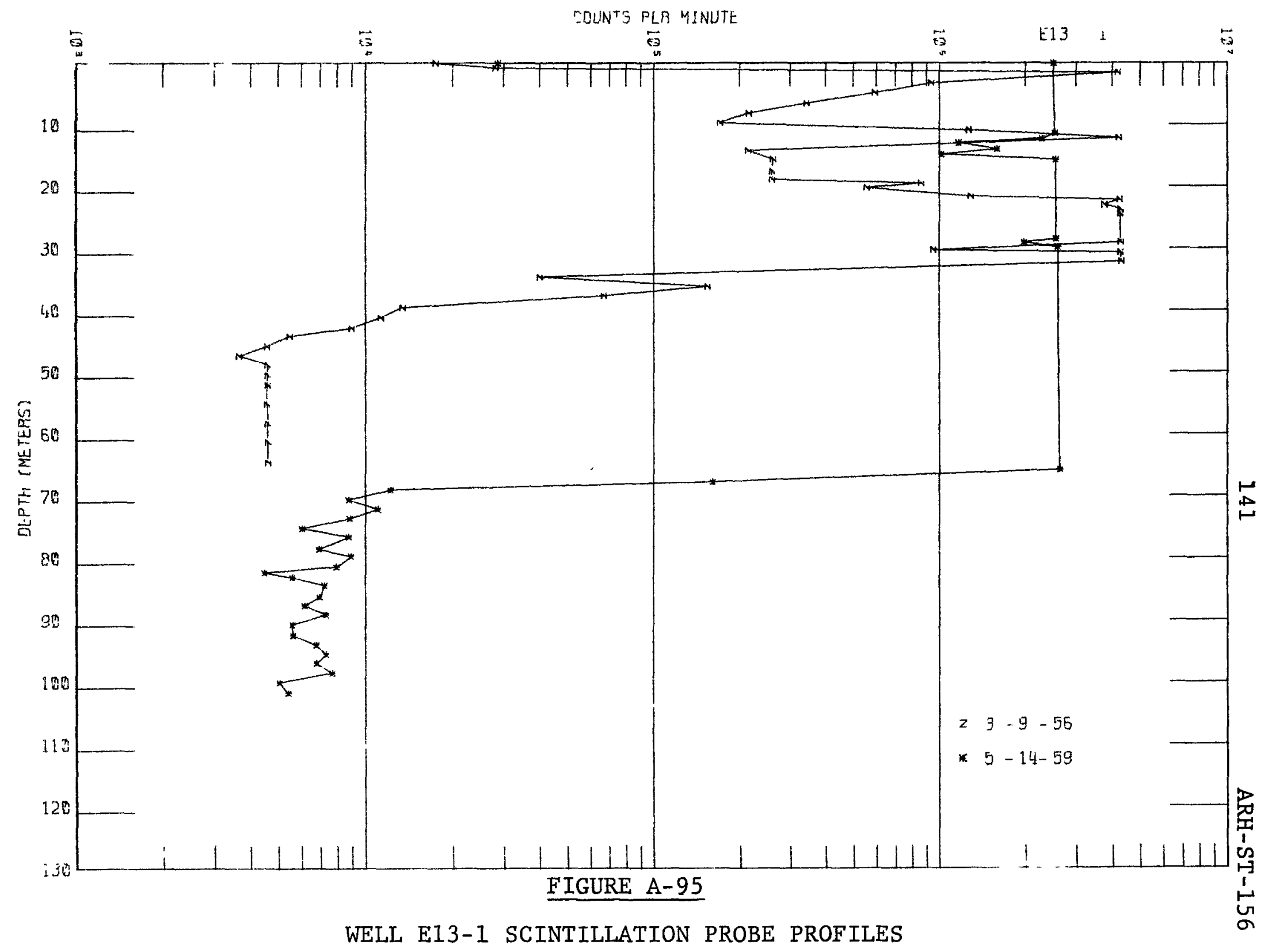

WELL E13-1 SCINTILLATION PROBE PROFILES 


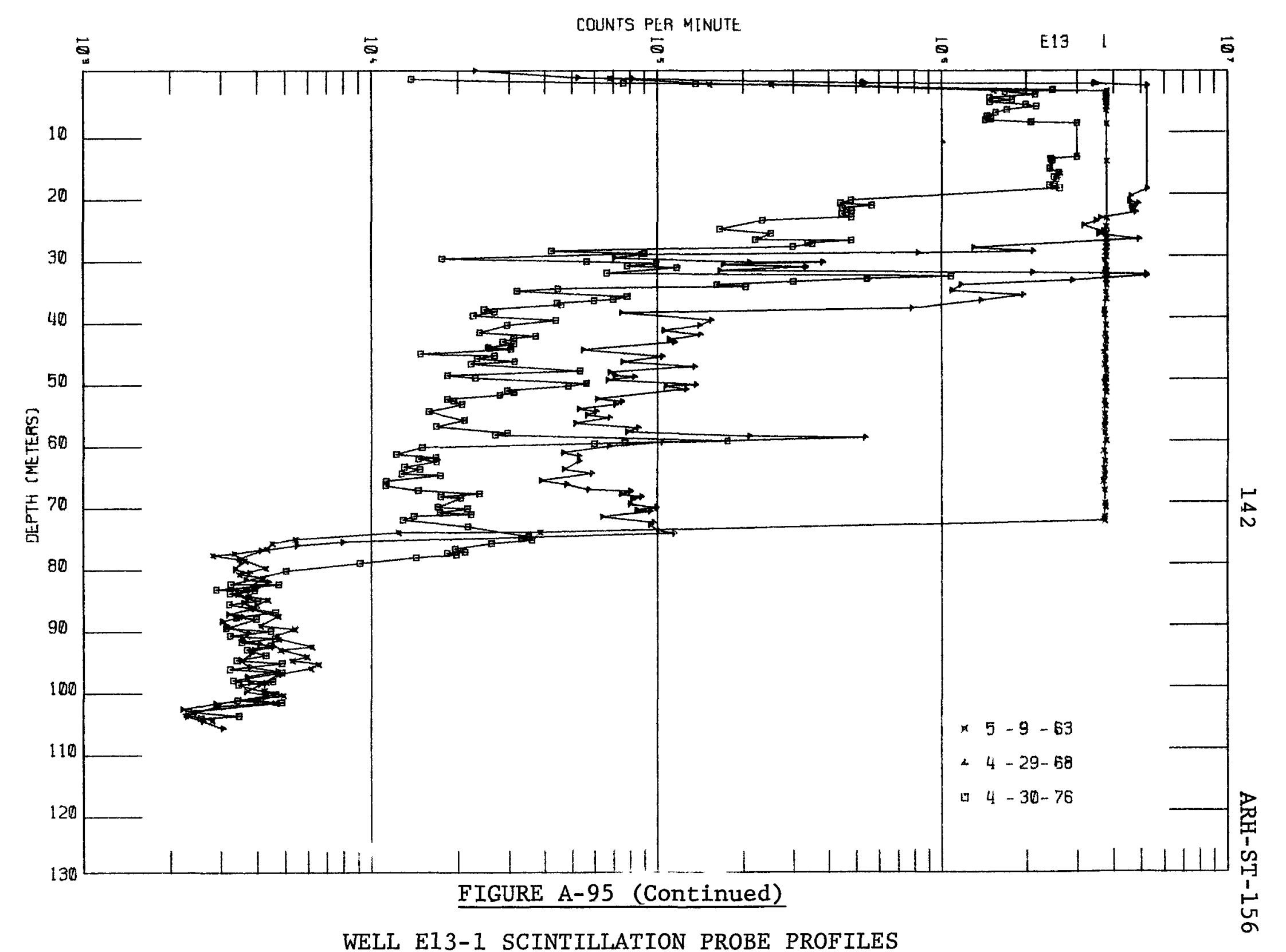


Description of Waste: Scavenged waste from uranium recovery (TBP solvent extraction) process in 221-U Building.

Service Dates: 1956 to 1957

Waste Volume: $6.32 \times 10^{6}$ liters

Waste Inventory:

\begin{tabular}{ccc} 
& Total & Decayed Thru June 1976 \\
\cline { 2 - 3 } $\mathrm{Pu}, \mathrm{g}$ & $5.00 \times 10^{0}$ & $5.00 \times 10^{0}$ \\
${ }^{\mathrm{Beta}, \mathrm{Ci}}$ & $6.90 \times 10^{4}$ & $5.12 \times 10^{2}$ \\
${ }^{90} \mathrm{Sr}, \mathrm{Ci}$ & $2.00 \times 10^{2}$ & $1.24 \times 10^{2}$ \\
${ }^{106} \mathrm{Ru}, \mathrm{Ci}$ & $2.20 \times 10^{4}$ & $2.70 \times 10^{-2}$ \\
${ }^{137} \mathrm{Cs}, \mathrm{Ci}$ & $2.00 \times 10^{2}$ & $1.28 \times 10^{2}$ \\
${ }^{60} \mathrm{Co}, \mathrm{Ci}$ & $5.00 \times 10^{0}$ & $3.79 \times 10^{-1}$ \\
$\mathrm{U}, \mathrm{kg}$ & $1.04 \times 10^{2}$ & $1.04 \times 10^{2}$
\end{tabular}

\section{Evaluation of Scintillation Probe Profiles:}

We11 E13-2 monitors the 216-B-15 crib (figures A-1 and A-94). In 1976 radioactive contaminants are detected between 1.2 and 49.7 meters below the ground surface (figure A-96).

The scintillation probe profiles from 1956, one month prior to disposal to the crib, show lateral spreading of waste from the 216-B-14 crib and possibly the 216-B-17 crib. The profiles from 1959 through 1968 show the contaminant front has penetrated an additional 9.1 meters. Since 1968 continued drainage has effectively stopped retaining the contaminants in the sediment column 67.6 meters above the water table. These data indicate breakthrough to groundwater has not occurred from waste disposal to the 216-B-15 crib. 


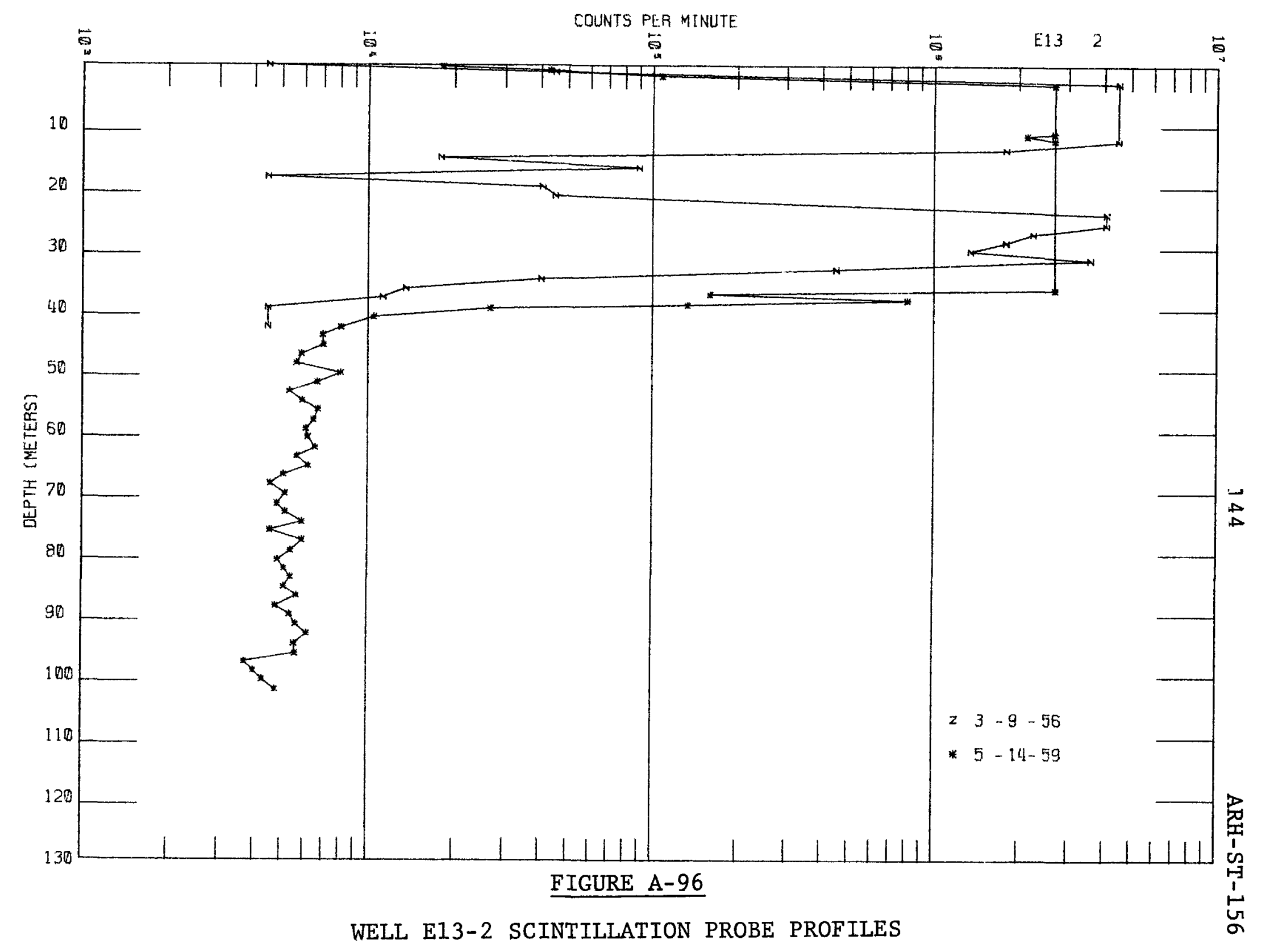


0 .

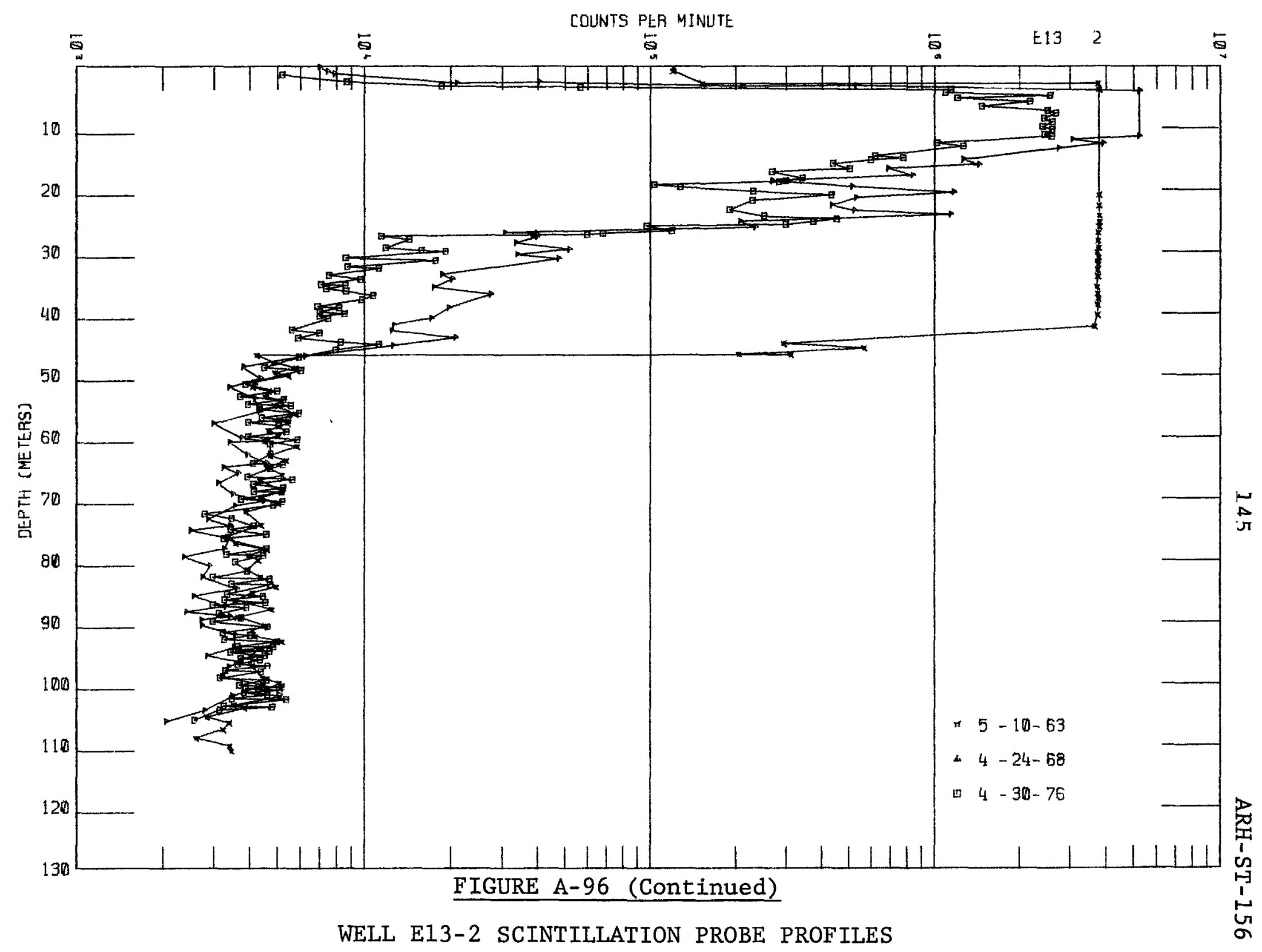


Description of Waste: Scavenged waste from uranium recovery (TBP solvent extraction) process in 221-U Building.

Service Dates: 1956

Waste Volume: $5.60 \times 10^{6}$ liters

Waste Inventory:

\begin{tabular}{ccc} 
& Total & Decayed Thru June 1976 \\
\cline { 2 - 3 } $\mathrm{Pu}, \mathrm{g}$ & $1.00 \times 10^{7}$ & $1.00 \times 10^{1}$ \\
${ }^{\text {Beta }, \mathrm{Ci}}$ & $5.40 \times 10^{4}$ & $1.66 \times 10^{3}$ \\
${ }^{90} \mathrm{Sr}, \mathrm{Ci}$ & $7.00 \times 10^{2}$ & $4.28 \times 10^{2}$ \\
${ }^{106} \mathrm{Ru}, \mathrm{Ci}$ & $1.30 \times 10^{4}$ & $1.33 \times 10^{-2}$ \\
${ }^{137} \mathrm{Cs}, \mathrm{Ci}$ & $6.50 \times 10^{2}$ & $4.10 \times 10^{2}$ \\
${ }^{60} \mathrm{Co}, \mathrm{Ci}$ & $5.00 \times 10^{0}$ & $3.58 \times 10^{-1}$ \\
$\mathrm{U}, \mathrm{kg}$ & $3.22 \times 10^{2}$ & $3.22 \times 10^{2}$
\end{tabular}

Evaluation of Scintillation Probe Profile:

We11s E13-3 and E13-21 monitor the 216-B-16 crib (figures A-1 and $A-94)$. In 1976 radioactive contaminants are detected between 2.4 and 36.6 meters below the ground surface in Well El3-3 and between 2.4 meters and the water table in Well E13-21 (figures A-97 and A-98).

The scintillation probe profiles from 1956, 5 months before waste disposal to the crib was terminated, thru 1963 show the contaminants front has penetrated an additional 7.1 meters. Since 1963 continued drainage has effectively stopped retaining most of the contamination high in the sediment column. The radiation intensity has continually decreased thru 1976 by radionuclide decay. The slow rate of decrease is due to the presence of long-lived radionuclides, mainly cesium. These data indicate breakthrough to the groundwater could have occurred at this site. 


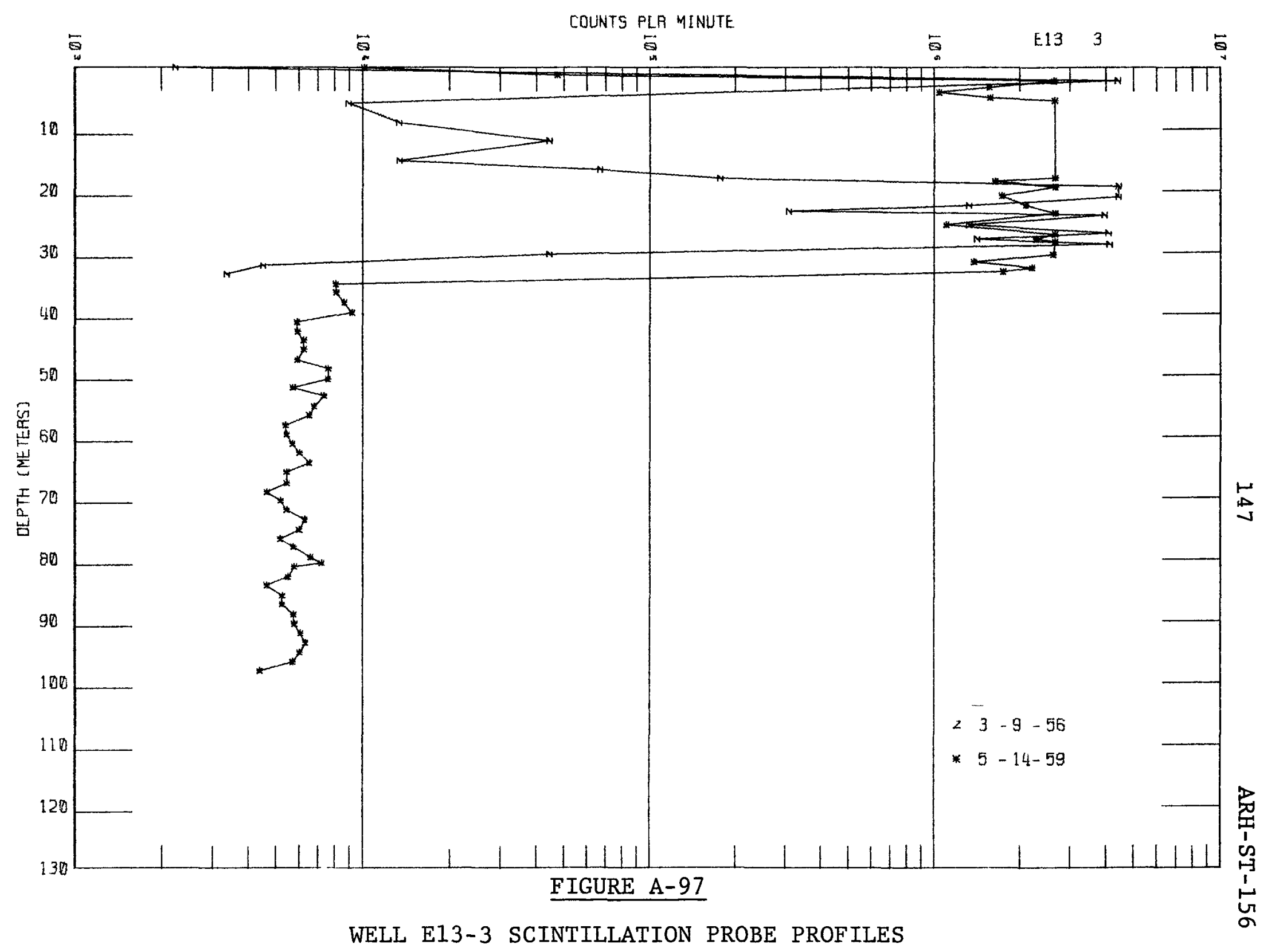




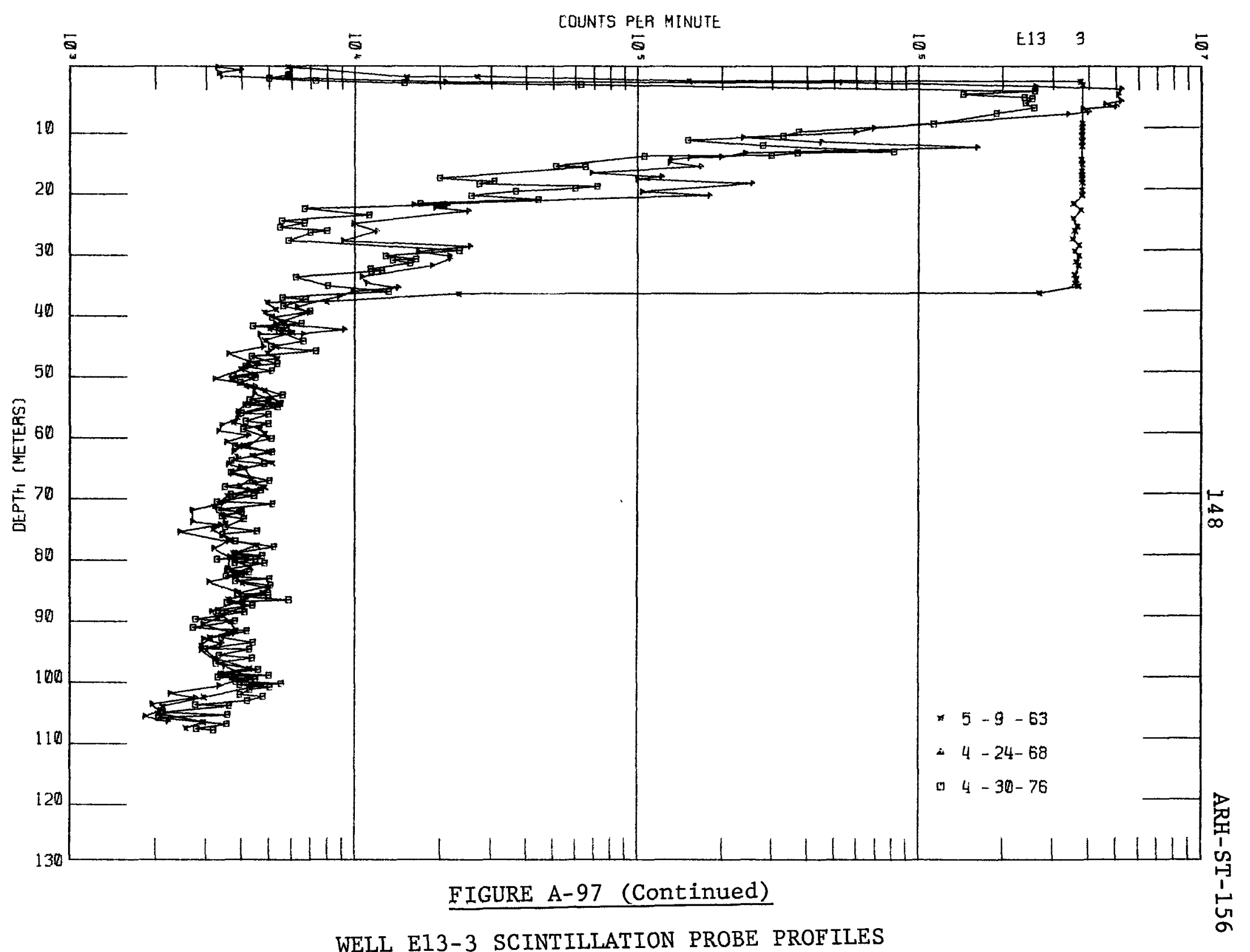

WELL E13-3 SCINTILLATION PROBE PROFILES 


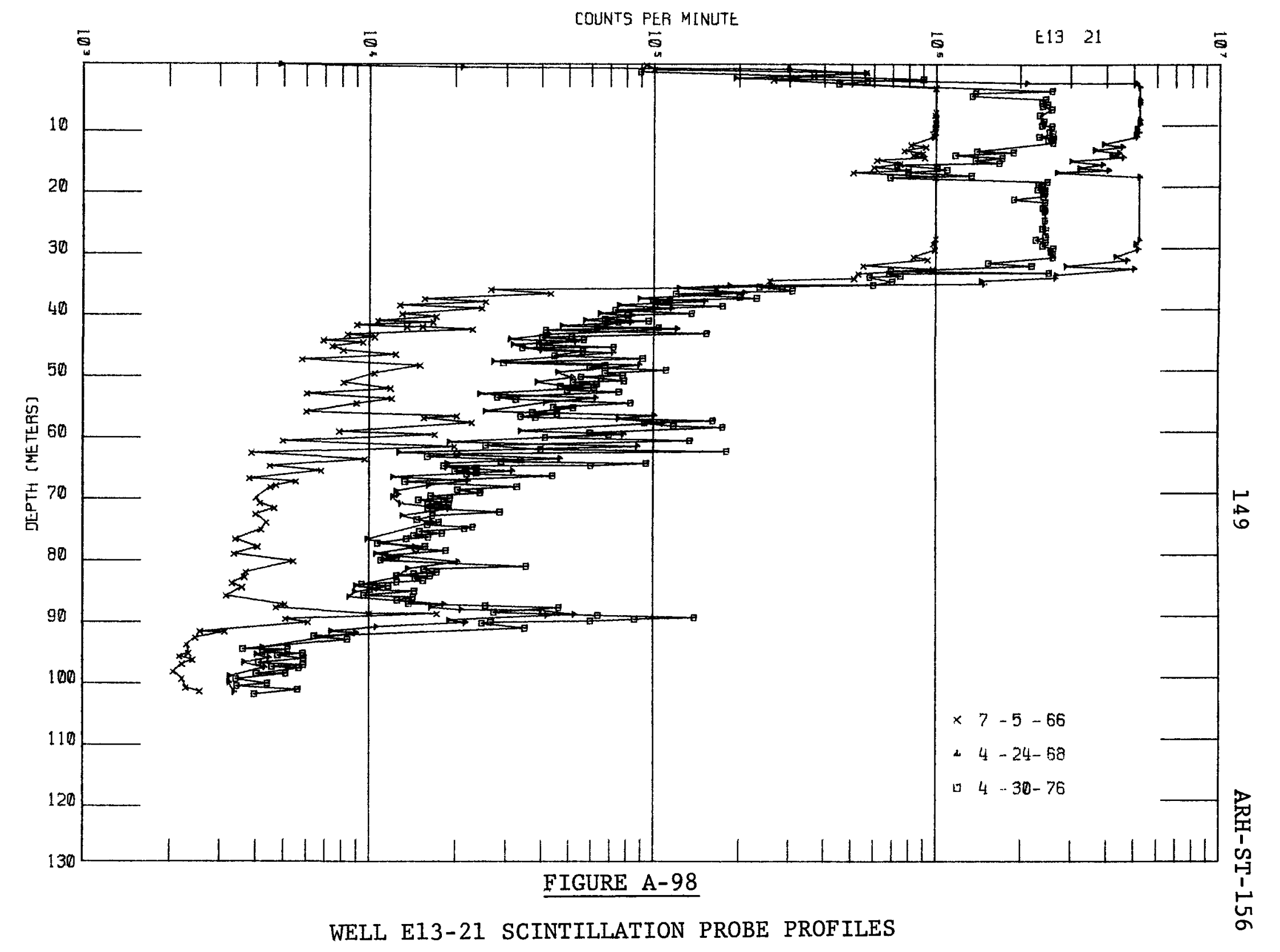




\section{6-B-17 Crib}

Description of Waste: Scavenged waste from uranium recovery (TBP solvent extraction) process in 221-U Building.

Service Dates: 1956

Waste Volume: $3.41 \times 10^{6}$ itters

Waste Inventory:

\begin{tabular}{|c|c|c|}
\hline & Total & Decayed Thru June 1976 \\
\hline $\mathrm{Pu}, \mathrm{g}$ & $1.00 \times 10^{1}$ & $1.00 \times 10^{1}$ \\
\hline Beta, Ci & $2.00 \times 10^{3}$ & $4.63 \times 10^{2}$ \\
\hline${ }^{90} \mathrm{Sr}, \mathrm{Ci}$ & $1.60 \times 10^{2}$ & $9.79 \times 10^{1}$ \\
\hline${ }^{106} \mathrm{Ru}, \mathrm{Ci}$ & $2.50 \times 10^{2}$ & $2.55 \times 10^{-4}$ \\
\hline${ }^{137} \mathrm{Cs}, \mathrm{Ci}$ & $2.20 \times 10^{2}$ & $1.39 \times 10^{2}$ \\
\hline${ }^{60} \mathrm{Co}, \mathrm{Ci}$ & $1.00 \times 10^{0}$ & $7.16 \times 10^{-2}$ \\
\hline $\mathrm{U}, \mathrm{kg}$ & $3.54 \times 10^{2}$ & $3.54 \times 10^{2}$ \\
\hline
\end{tabular}

Evaluation of Scintillation Probe Profiles:

We11 E13-4 monitors the 216-B-17 crib (figures $A-1$ and A-94). In 1976 radioactive contaminants are detected between 3.3 and 30.5 meters below the ground surface (figure A-99).

The scintillation probe profiles from 1956, two months after waste disposal to the crib was terminated, thru 1963 show the contaminant front has penetrated an additional 3.0 meters. Since 1963 continued drainage has effectively stopped retaining the contamination in the sediment column 73.8 meters above the water table. The radiation intensity has continually decreased thru 1976 by radionuclide decay. The slow rate of decrease is due to the presence of long-lived radionuclides. These data indicate breakthrough to the groundwater has not occurred at this site. 


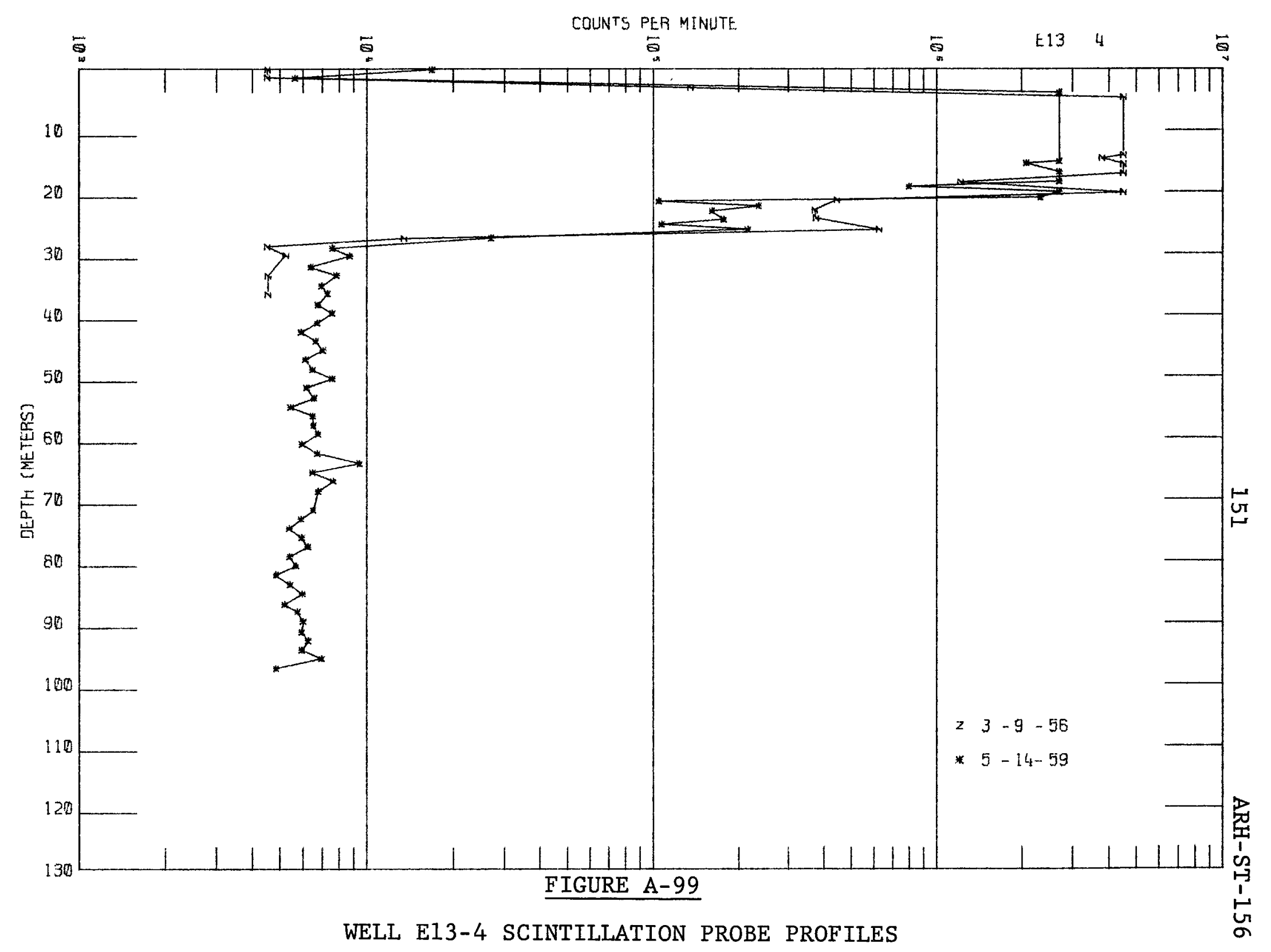




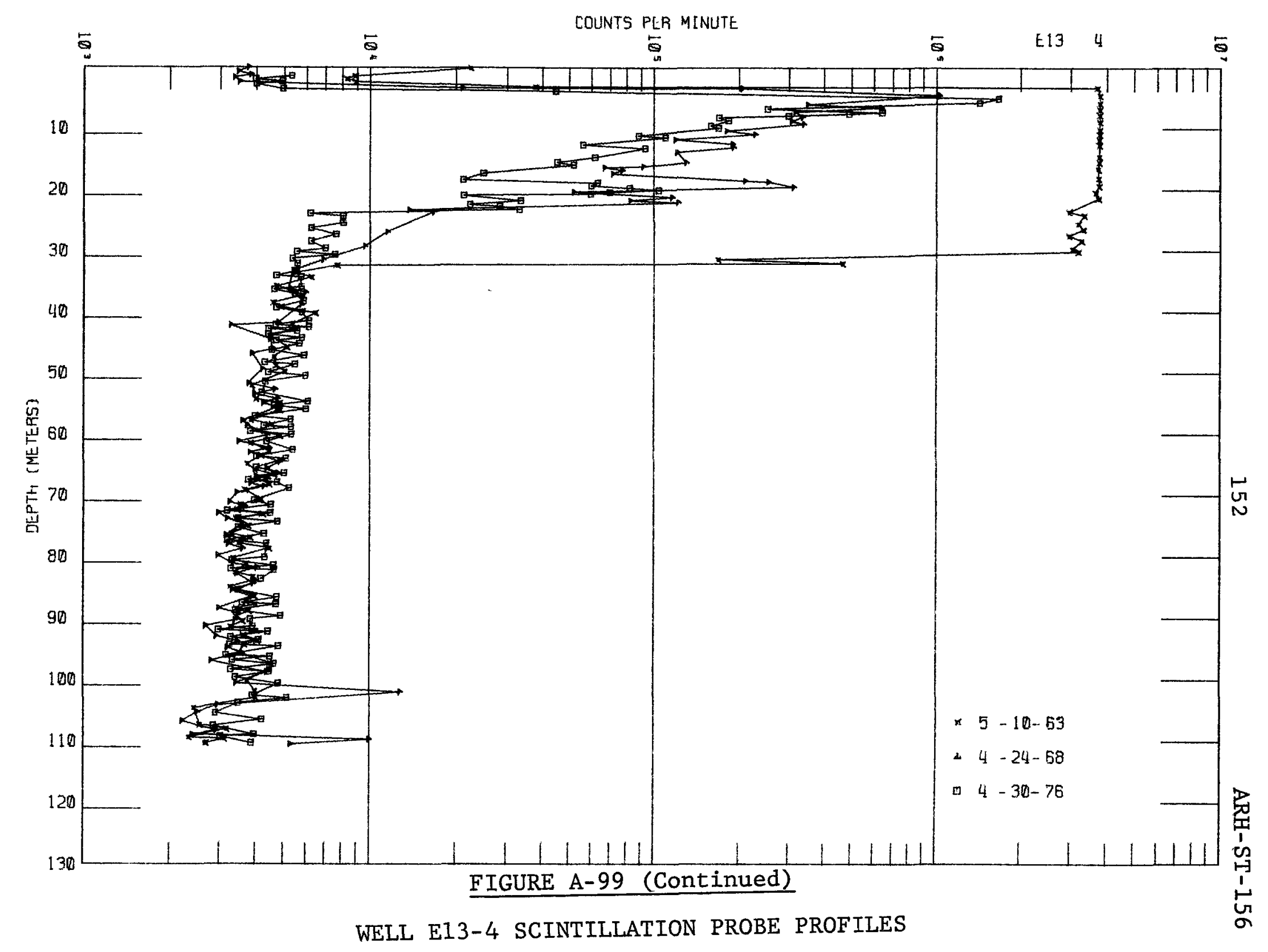




\section{6-B-18 Crib}

Description of Waste: Scavenged waste from uranium recovery (TBP solvent extraction) process in 221-U Building.

\section{Service Dates: 1956}

Waste Volume: $8.52 \times 10^{6}$ liters

Waste Inventory:

\begin{tabular}{|c|c|c|}
\hline & Total & Decay thru June 1976 \\
\hline $\mathrm{Pu}, \mathrm{g}$ & $1.00 \times 10^{1}$ & $1.00 \times 10^{7}$ \\
\hline Beta, Ci & $5.10 \times 10^{4}$ & $5.44 \times 10^{2}$ \\
\hline${ }^{90} \mathrm{Sr}, \mathrm{Ci}$ & $1.90 \times 10^{2}$ & $1.16 \times 10^{2}$ \\
\hline${ }^{106} \mathrm{Ru}, \mathrm{Ci}$ & $1.90 \times 10^{4}$ & $1.94 \times 10^{-2}$ \\
\hline${ }^{137} \mathrm{Cs}, \mathrm{Ci}$ & $2.50 \times 0^{2}$ & $1.58 \times 10^{2}$ \\
\hline${ }^{60} \mathrm{Co}, \mathrm{Ci}$ & $5.00 \times 10^{0}$ & $3.58 \times 10^{-1}$ \\
\hline $\mathrm{U}, \mathrm{kg}$ & $2.36 \times 10^{2}$ & $2.36 \times 10^{2}$ \\
\hline
\end{tabular}

\section{Evaluation of Scintillation Probe Profiles:}

We11 El3-5 monitors the 216-B-18 crib (figures A-1 and A-94). In 1976 radioactive contaminants are detected between 1.5 and 25.9 meters below the ground surface (figure A-100).

The scintillation probe profiles from 1956, during crib operation, through 1959 show the contaminant front has penetrated an additional 16.0 meters of the sediment column. Most of the drainage detected is attributed to crib operations. Since 1959, the radiation intensity has increased in the lower portion of the zone contamination due to lateral migration, but sediment drainage has effectively stopped. These data indicate breakthrough to the groundwater has not occurred at this site. 


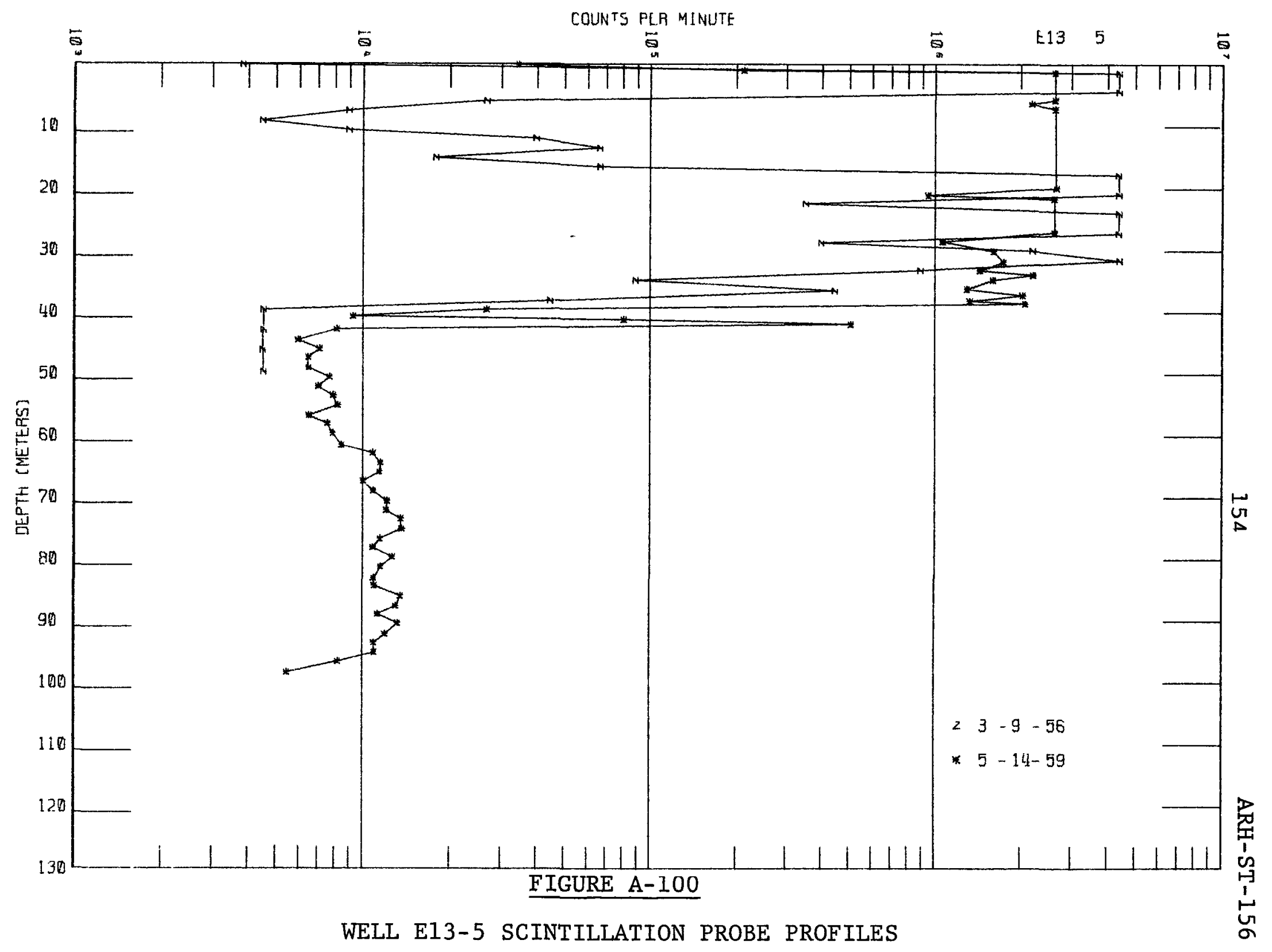




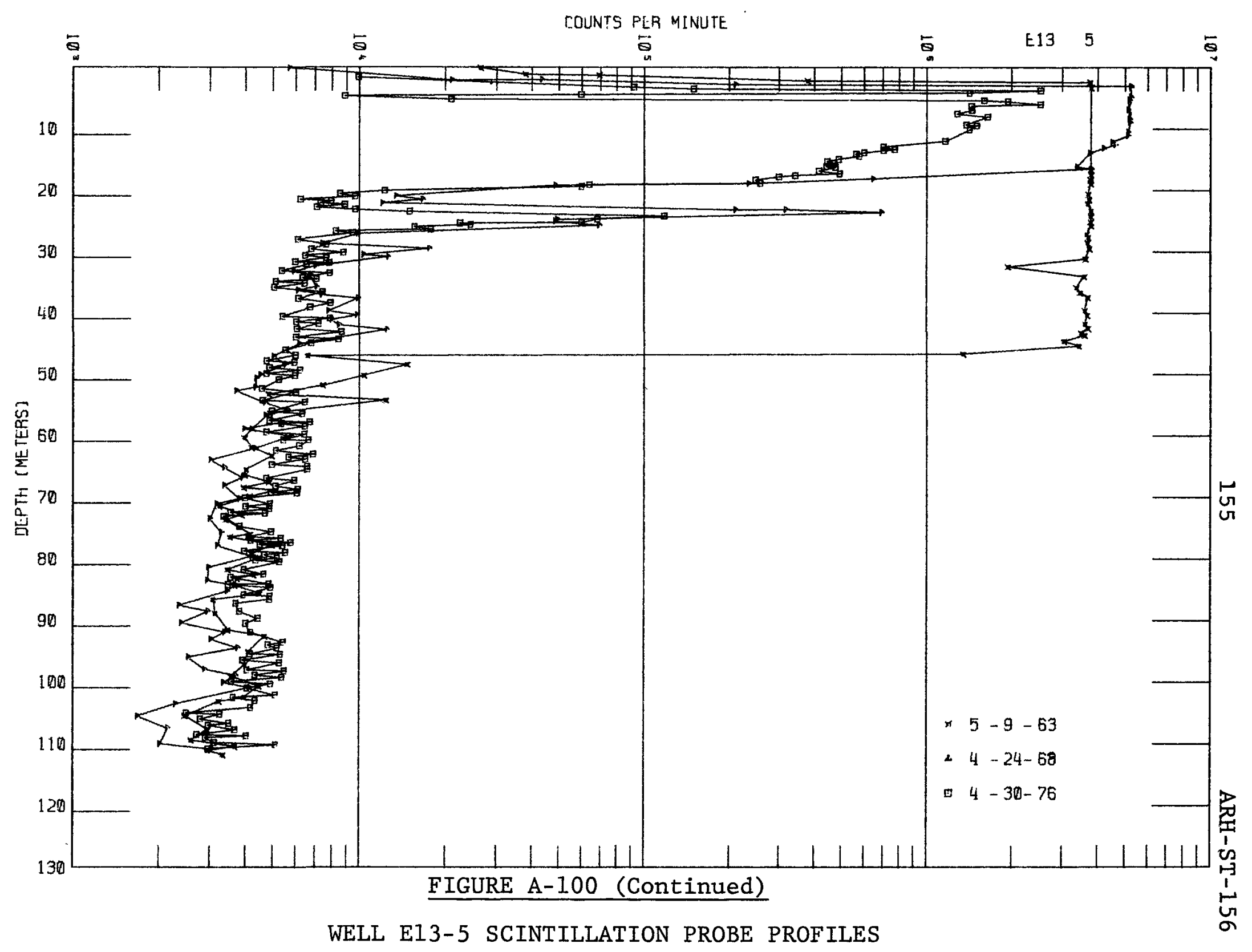




\section{6-B-19 Crib}

Description of Waste: Scavenged waste from uranium recovery (TBP solvent extraction) process in 221-U Building.

Service Dates: 1957

Waste Volume: $6.40 \times 10^{6}$ liters

Waste Inventory:

\begin{tabular}{|c|c|c|}
\hline & Total & Decay thru June 1976 \\
\hline $\mathrm{Pu}, \mathrm{g}$ & $1.00 \times 10^{1}$ & $1.00 \times 10^{1}$ \\
\hline Beta, Ci & $1.12 \times 10^{4}$ & $5.86 \times 10^{2}$ \\
\hline${ }^{90} \mathrm{Sr}, \mathrm{Ci}$ & $2.00 \times 10^{2}$ & $1.25 \times 10^{2}$ \\
\hline${ }^{106} \mathrm{Ru}, \mathrm{Cj}$ & $5.10 \times 10^{3}$ & $1.04 \times 10^{-2}$ \\
\hline${ }^{137} \mathrm{Cs}, \mathrm{Ci}$ & $2.70 \times 10^{2}$ & $1.74 \times 10^{2}$ \\
\hline${ }^{60} \mathrm{Co}, \mathrm{Cj}$ & $5.00 \times 10^{0}$ & $4.08 \times 10^{-1}$ \\
\hline $\mathrm{U}, \mathrm{kg}$ & $1.81 \times 10^{2}$ & $1.81 \times 10^{2}$ \\
\hline
\end{tabular}

Evaluation of Scintillation Probe Profiles:

We11 E13-6 monitors the 216-B-19 crib (figures A-1 and A-94). In 1976 radioactive contaminants are detected between 1 and 62.5 meters below the ground surface (figure A-101).

The scintillation probe profiles from 1956, 11 months before waste discharges to the crib began, show contaminants migrating laterally from the 216-B-16, 17 and 18 cribs. Soil drainage occurred from waste discharged to the 216-B-19 crib between 1959 and 1963 as the contaminant front penetrated an additional 6.1 meters. Since 1963 continued drainage has effectively stopped retaining the contamination in the sediment column 38.7 meters above the water table. These data indicate breakthrough to the groundwater has not occurred at this site. 


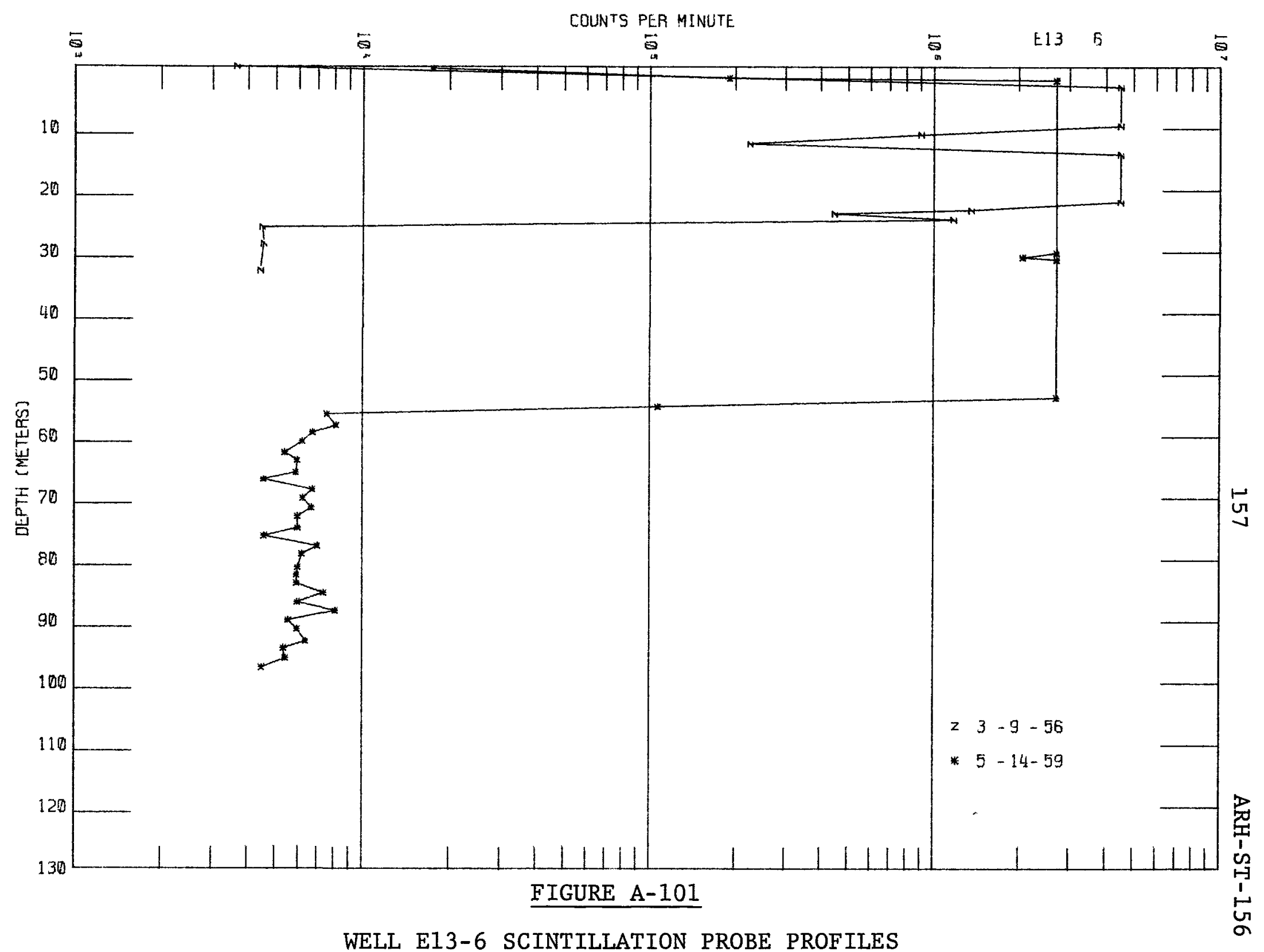




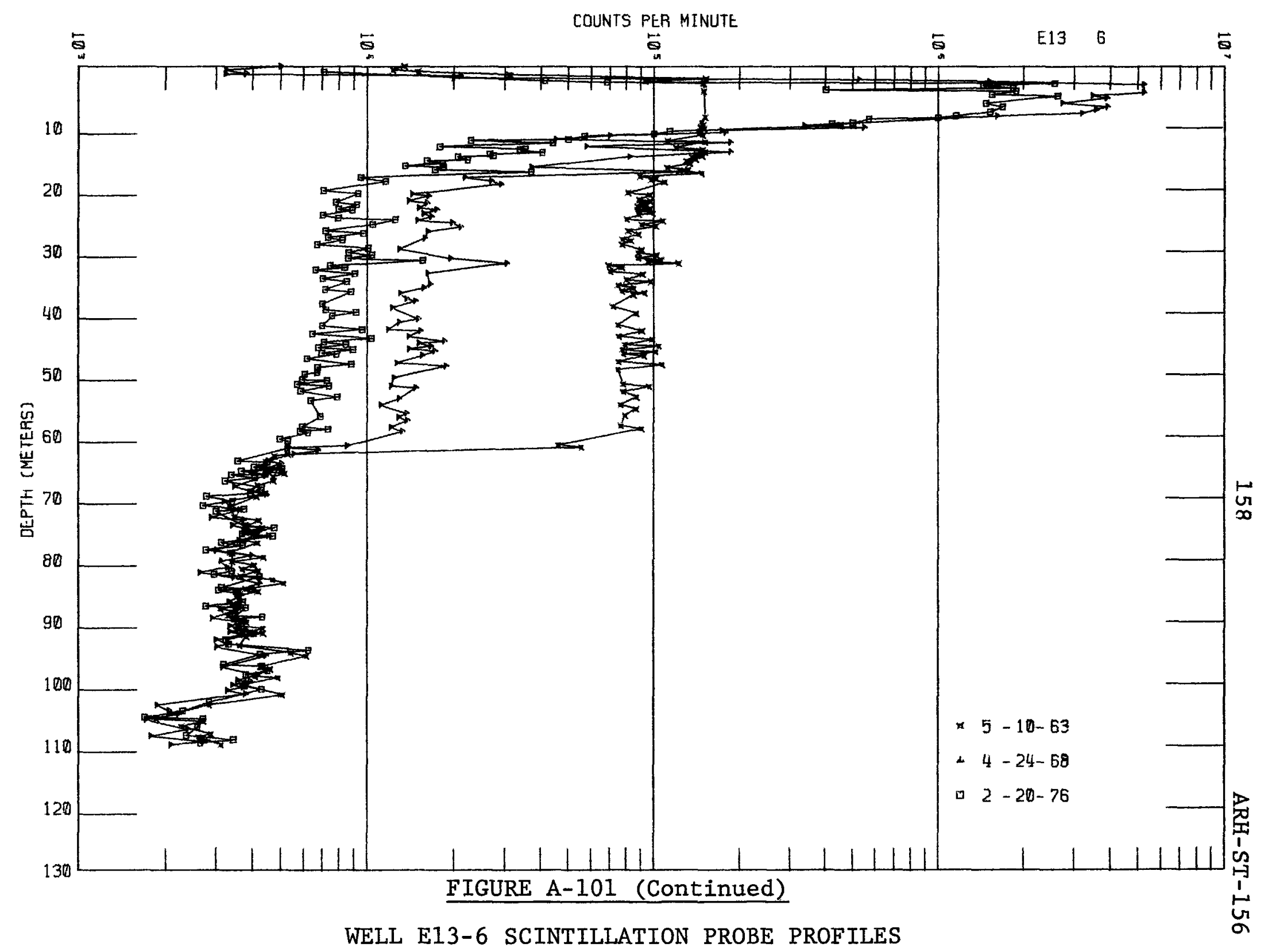




\section{6-B-20 Specific Retention Trench}

Description of Waste: Scavenged waste from uranium recovery (TBP solvent extraction) process in 221-U Building.

Service Dates: 1956

Waste Volume: $4.68 \times 10^{6}$ liters

Waste Inventory:

\begin{tabular}{|c|c|c|}
\hline & Total & Decay thru June 1976 \\
\hline $\mathrm{Pu}, \mathrm{g}$ & $1.30 \times 10^{0}$ & $1.30 \times 10^{0}$ \\
\hline Beta, Ci & $3.15 \times 0^{4}$ & $2.80 \times 10^{3}$ \\
\hline${ }^{90} \mathrm{Sr}, \mathrm{Ci}$ & $7.90 \times 10^{2}$ & $4.83 \times 10^{2}$ \\
\hline${ }^{106} \mathrm{Ru}, \mathrm{Ci}$ & $9.98 \times 10^{4}$ & $1.02 \times 10^{-2}$ \\
\hline${ }^{137} \mathrm{Cs}, \mathrm{Ci}$ & $1.51 \times 10^{3}$ & $9.50 \times 10^{2}$ \\
\hline${ }^{60} \mathrm{Co}, \mathrm{Ci}$ & $4.40 \times 10^{0}$ & $3.15 \times 10^{-1}$ \\
\hline $\mathrm{U}, \mathrm{kg}$ & $3.52 \times 10^{2}$ & $3.52 \times 10^{2}$ \\
\hline
\end{tabular}

Evaluation of Scintillation Probe Profiles:

We11 E13-7 monitors the 216-B-20 specific retention trench (figures $A-1$ and A-102). Radioactive contaminants detected at the ground surface in 1959 and 1963 have decreased to background levels (figure A-103). In 1976 the zone of contamination is between 4.6 and 33.5 meters below the ground surface.

The scintillation probe profiles from 1959 thru 1968 show the contaminant front has penetrated an additional 6.1 meters. Since 1968 continued drainage has effectively stopped, retaining the contaminants high in the sediment column 83.8 meters above the water table. The radiation intensity in zone of contamination has been decreasing by radionuclide decay. These data indicate breakthrough to the groundwater has not occurred at this site. 


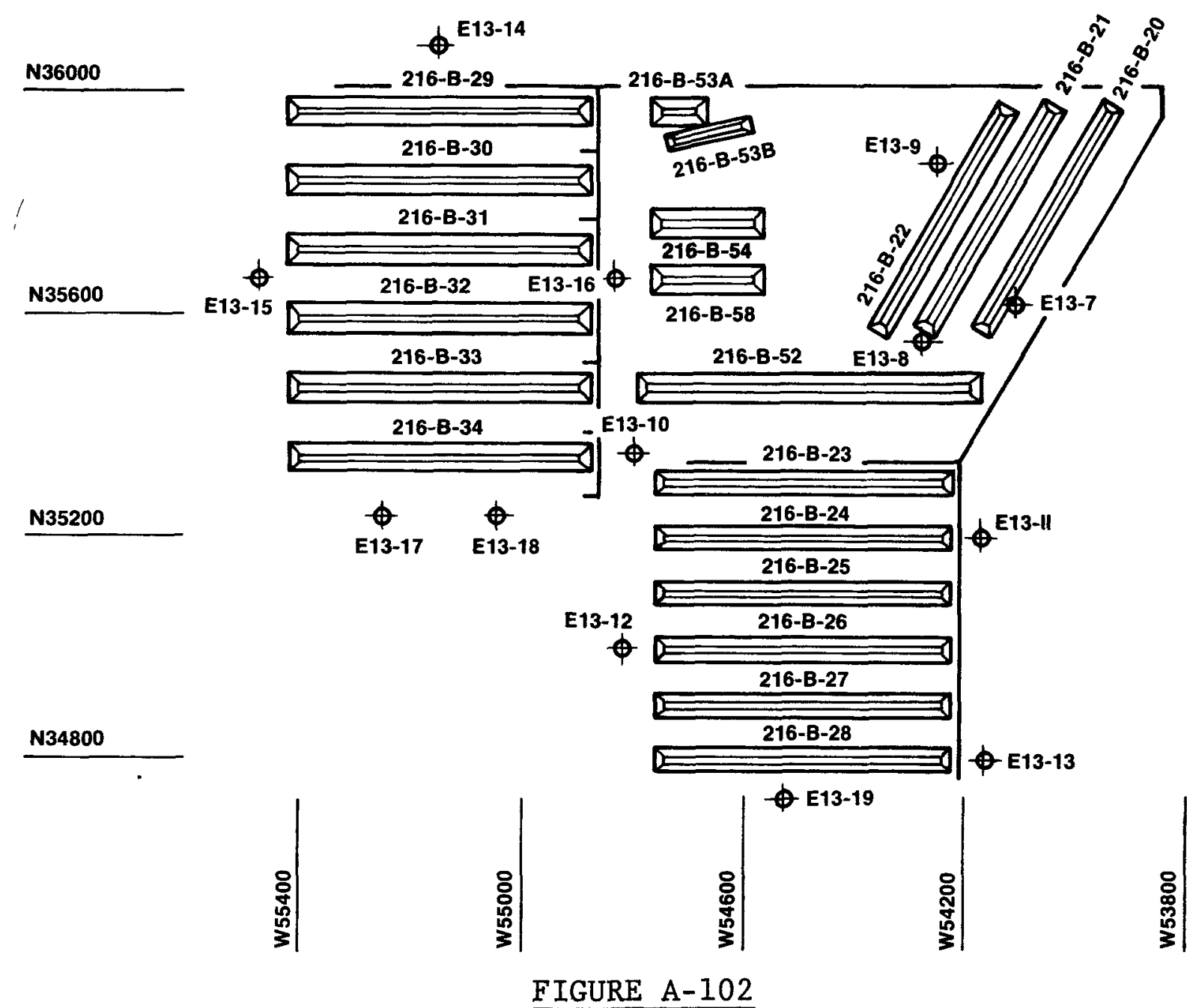

216-B-20 THROUGH 216-B-34, 216-B-52, 216-B-53A AND B, 216-B-54 AND 216-B-58 CRIB PLOT PLANS 

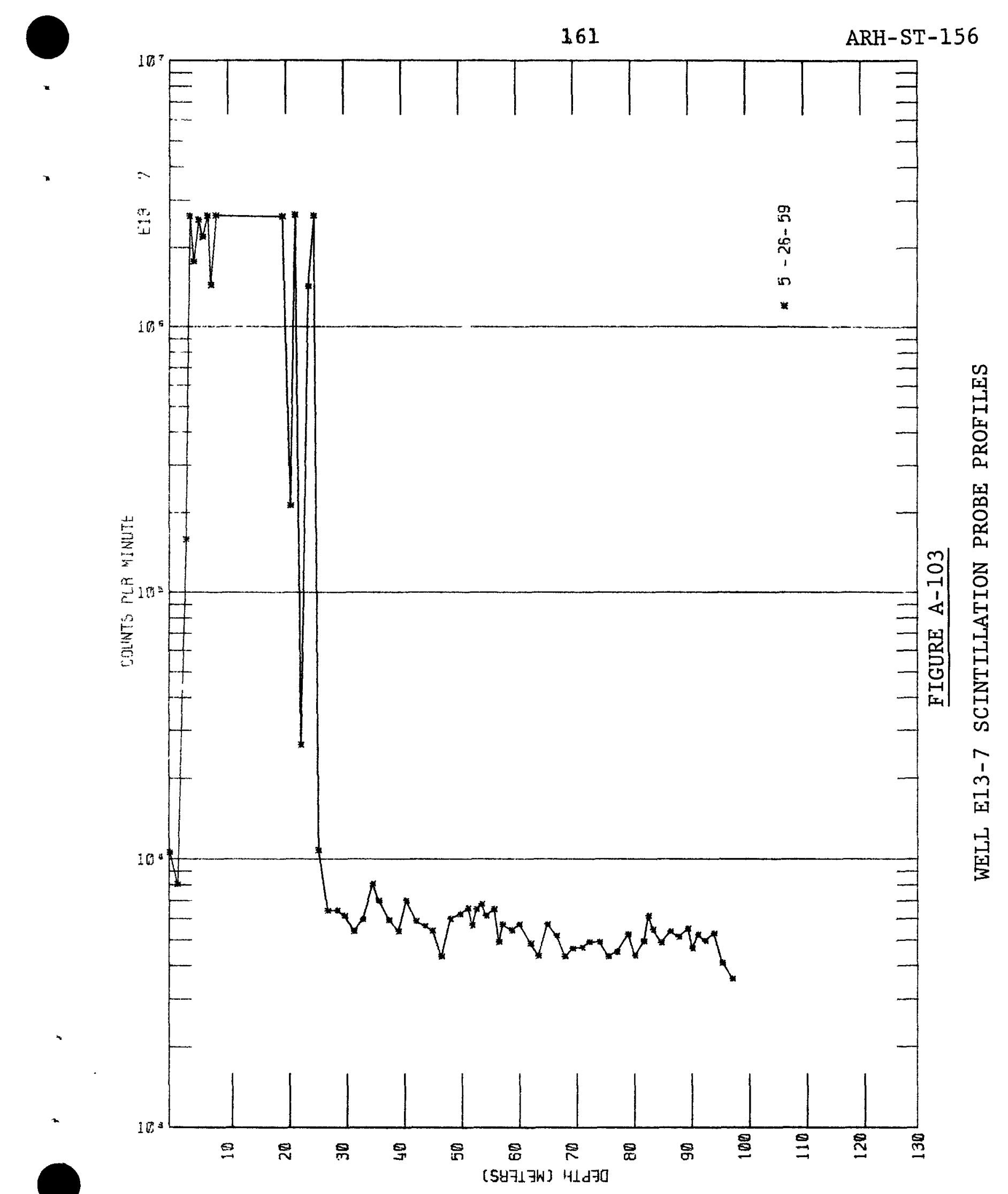


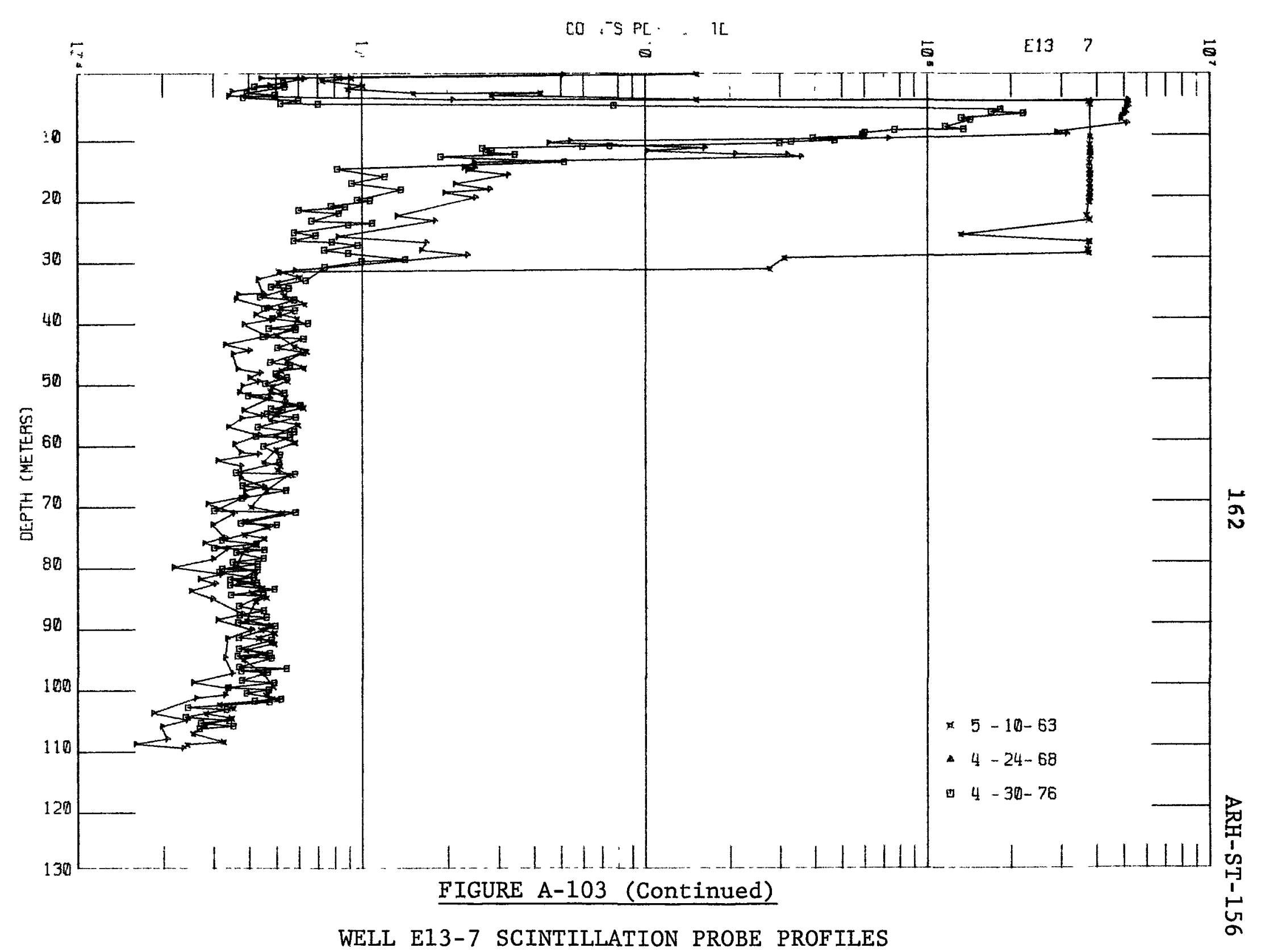




\section{6-B-21 Specific Retention Trench}

Description of Waste: Scavenged waste from uranium recovery (TBP solvent extraction) process in $221-U$.

Service Dates: 1956

Waste Volume: $4.67 \times 10^{6}$ liters

Waste Inventory:

\begin{tabular}{|c|c|c|}
\hline & Total & Decay Thru June 1976 \\
\hline $\mathrm{Pu}, \mathrm{g}$ & $1.03 \times 10^{7}$ & $1.03 \times 10^{1}$ \\
\hline Beta, Ci & $4.65 \times 10^{4}$ & $1.37 \times 10^{4}$ \\
\hline${ }^{90} \mathrm{Sr}, \mathrm{Ci}$ & $7.39 \times 10^{2}$ & $4.52 \times 10^{2}$ \\
\hline${ }^{106} \mathrm{Ru}, \mathrm{Ci}$ & $1.47 \times 10^{4}$ & $1.50 \times 10^{-2}$ \\
\hline${ }^{137} \mathrm{Cs}, \mathrm{Ci}$ & $3.72 \times 10^{2}$ & $2.35 \times 10^{2}$ \\
\hline${ }^{60} \mathrm{Co}, \mathrm{Ci}$ & $6.50 \times 10^{0}$ & $4.65 \times 10^{-1}$ \\
\hline $\mathrm{U}, \mathrm{kg}$ & $6.75 \times 10^{2}$ & $6.75 \times 10^{2}$ \\
\hline
\end{tabular}

\section{Evaluation of Scintillation Probe Profiles:}

We11 E13-8 monitors the 216-B-21 specific retention trench (figures $A-1$ and A-102). Radioactive contaminants detected at the ground surface in 1959 and 1963 have decreased to background levels (figure A-104). In 1976 the zone of contamination is between 9.4 and 25.3 meters below the ground surface.

The scintillation probe profiles from 1959 and 1963 show the contaminant front had penetrated an additional 3.0 meters of the sediment column from soil drainage. Since 1963 continued drainage has effectively stopped, retaining the contamination high in the sediment column 77.7 meters above the water table. The radiation intensity in the zone of contamination has been decreasing by radioactive decay. These data indicate that breakthrough to the groundwater has not occurred at this site. 


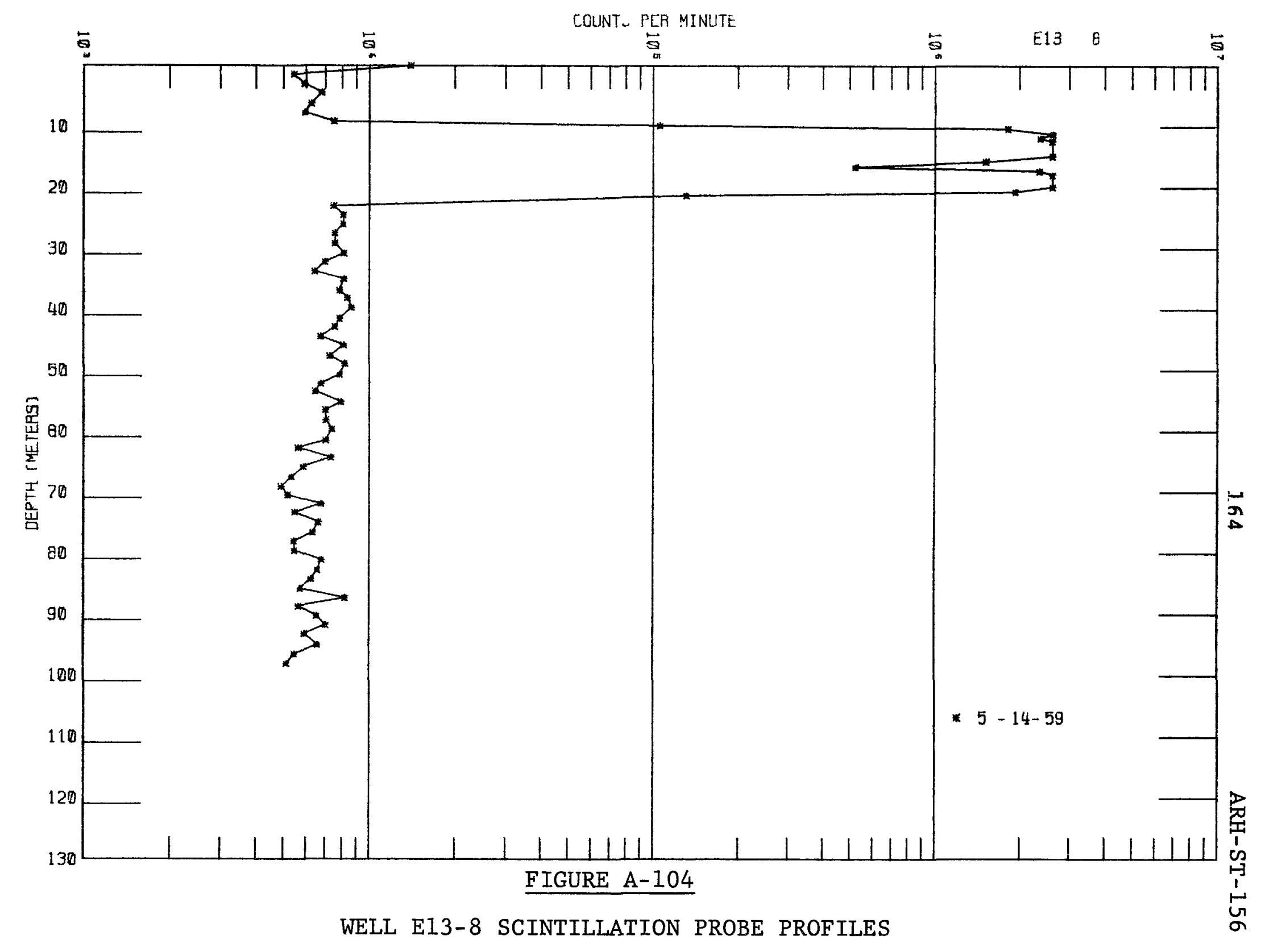




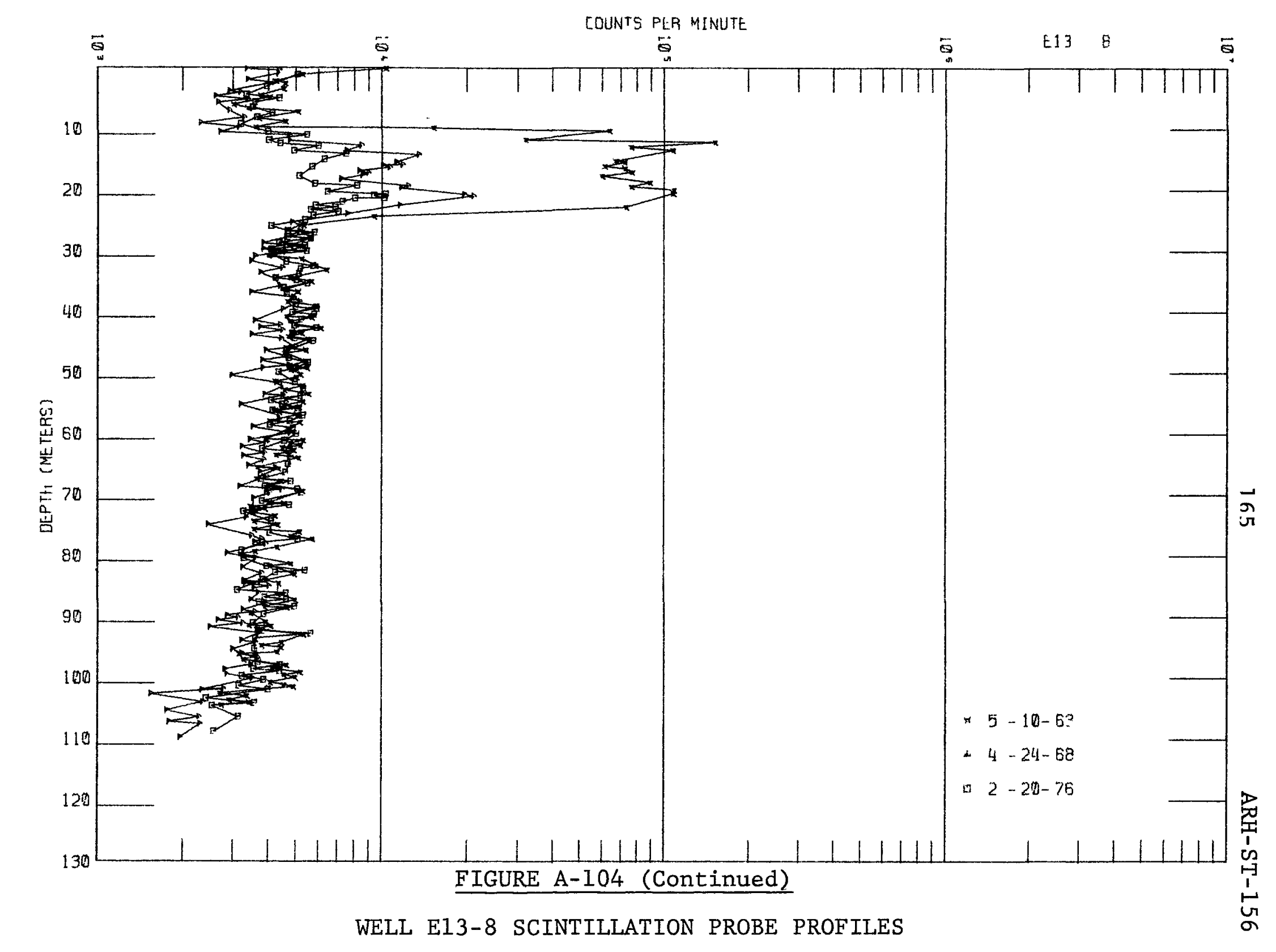




\section{6-B-22 Specific Retention Trench}

Description of Waste: Scavenged waste from uranium recovery (TBP solvent extraction) process in 221-U Building.

Service Dates: 1956

Waste Volume: $4.74 \times 10^{6}$ liters

Waste Inventory:

\begin{tabular}{|c|c|c|}
\hline & Total & Decay Thru June 1976 \\
\hline $\mathrm{Pu}, \mathrm{g}$ & $2.6 \times 10^{0}$ & $2.6 \times 10^{0}$ \\
\hline Beta, Ci & $9.52 \times 10^{4}$ & $5.78 \times 10^{2}$ \\
\hline & $4.08 \times 10^{2}$ & $2.50 \times 10^{2}$ \\
\hline${ }^{106} \mathrm{Ru}, \mathrm{Ci}$ & $3.01 \times 10^{4}$ & $3.08 \times 10^{-2}$ \\
\hline${ }^{137} \mathrm{Cs}, \mathrm{Ci}$ & $4.50 \times 10^{7}$ & $2.84 \times 10^{7}$ \\
\hline${ }^{60} \mathrm{Co}, \mathrm{Ci}$ & $1.34 \times 10^{1}$ & $9.59 \times 10^{-1}$ \\
\hline $\mathrm{U}, \mathrm{kg}$ & $4.18 \times 10^{2}$ & $4.18 \times 10^{2}$ \\
\hline
\end{tabular}

Evaluation of Scintillation Probe Profiles:

Well E13-9 monitors the 216-B-22 specific retention trench (figures $A-1$ and A-102). Radioactive contaminants detected at the ground surface and at the 12.8 meter depth have decreased in radiation intensity to near background levels (figure A-105).

The scintillaltion probe profiles from 1959 and 1968 show the contaminant front has penetrated an additional 3.5 meters of the sediment column from soil drainage. Since 1968 continued drainage has effectively stopped and the radiation intensity decreased by radionuclide decay to near background levels. These data indicate breakthrough to the groundwater has not occurred at this site. 


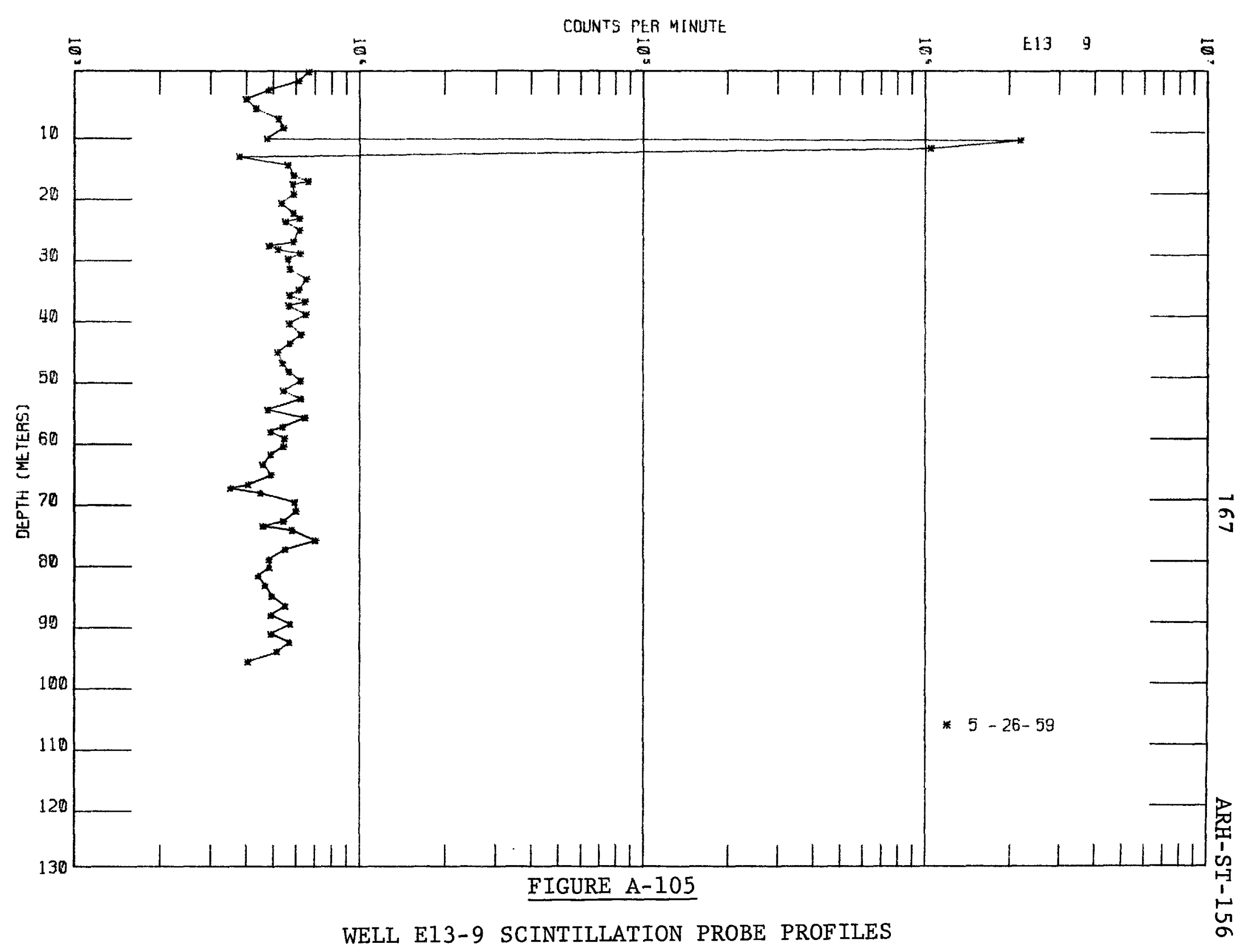




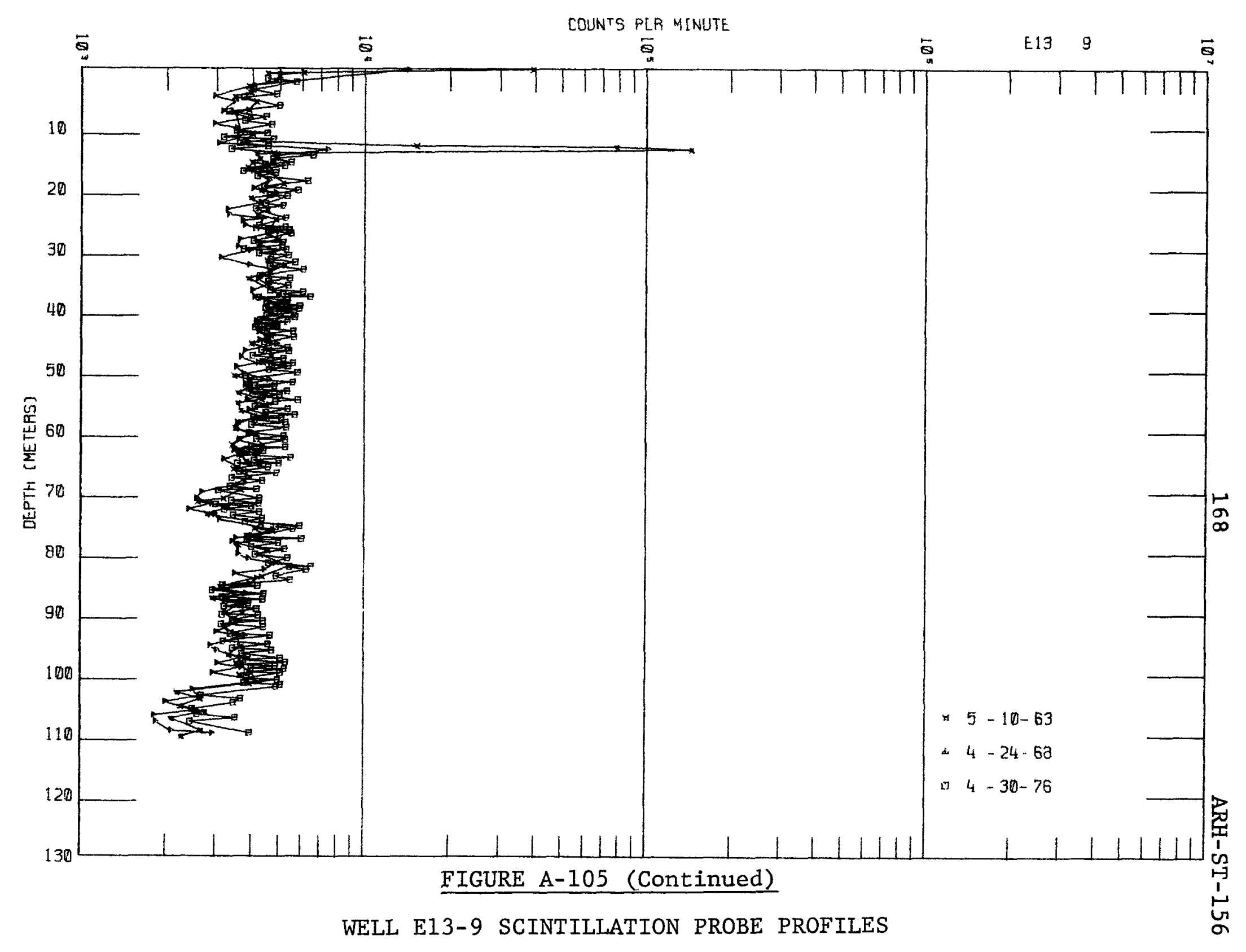




\section{6-B-24 Specific Retention Trench}

Description of Waste: Scavenged waste from uranium recovery (TBP solvent extraction) process in 221-U.

Service Dates: 1956

Waste Volume: $4.70 \times 10^{6}$ iiters

Waste Inventory:

\begin{tabular}{rcc} 
& Total & Decay Thru June 1976 \\
\cline { 2 - 3 } $\mathrm{Pu}, \mathrm{g}$ & $7.70 \times 10^{0}$ & $7.70 \times 10^{0}$ \\
${ }^{\text {Beta, } \mathrm{Ci}}$ & $7.30 \times 10^{4}$ & $3.97 \times 10^{2}$ \\
${ }^{90} \mathrm{Sr}, \mathrm{Ci}$ & $1.81 \times 10^{3}$ & $1.11 \times 10^{2}$ \\
${ }^{106} \mathrm{Ru}, \mathrm{Ci}$ & $2.31 \times 10^{4}$ & $2.36 \times 10^{-2}$ \\
${ }^{137} \mathrm{Cs}, \mathrm{Ci}$ & $1.29 \times 10^{2}$ & $8.14 \times 10^{7}$ \\
${ }^{60} \mathrm{Co}, \mathrm{Ci}$ & $1.03 \times 10^{1}$ & $7.37 \times 10^{-1}$ \\
$\mathrm{U}, \mathrm{kg}$ & $2.46 \times 10^{2}$ & $2.46 \times 10^{2}$
\end{tabular}

\section{Evaluation of Scintillation Probe Profiles:}

We11 E13-11 monitors the 216-B-24 specific retention trench (figures $A-1$ and $A-102)$. The scintillation profiles show near background levels of radiation (figure A-106). These data indicate breakthrough to the groundwater has not occurred at this site. 
- .

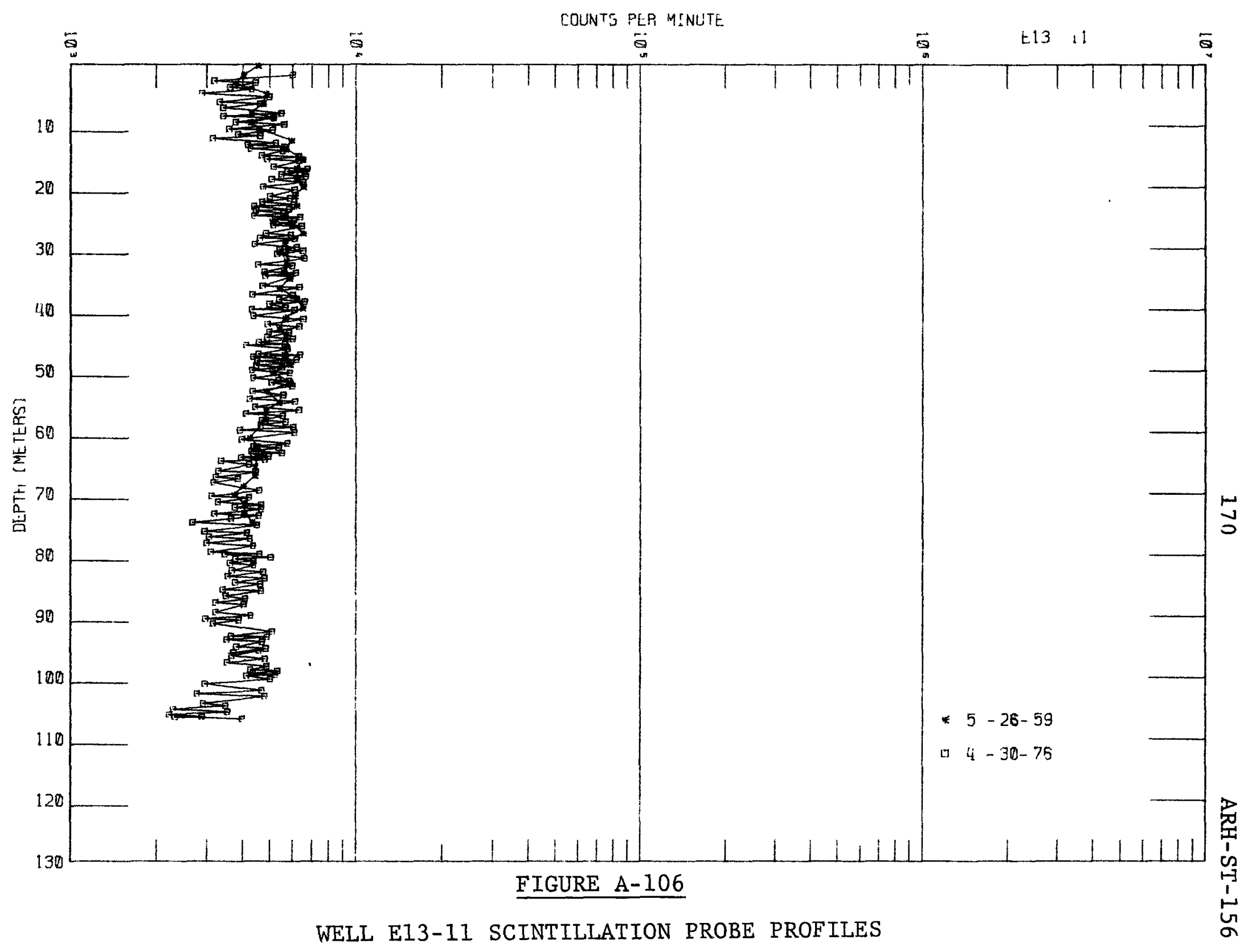




\section{6-B-26 Specific Retention Trench}

Description of Waste: Scavenged waste from uranium recovery (TBD soivent extraction) process in 2210 Building.

Service Dates: 1956 and 1957

Waste Volume: $5.88 \times 10^{6}$ liters

Waste Inventory:

\begin{tabular}{|c|c|c|}
\hline & Total & Decay Thru June 1976 \\
\hline $\mathrm{Pu}, \mathrm{g}$ & $2.50 \times 10^{0}$ & $2.50 \times 10^{0}$ \\
\hline Beta, Ci & $7.68 \times 10^{4}$ & $2.53 \times 10^{3}$ \\
\hline${ }^{90} \mathrm{Sr}, \mathrm{Ci}$ & $1.09 \times 10^{3}$ & $6.74 \times 10^{2}$ \\
\hline${ }^{106} \mathrm{Ru}, \mathrm{Ci}$ & $2.43 \times 10^{4}$ & $3.62 \times 10^{-2}$ \\
\hline${ }^{137} \mathrm{Cs}, \mathrm{Ci}$ & $9.5 \times 10^{2}$ & $6.08 \times 10^{2}$ \\
\hline${ }^{60} \mathrm{Co}, \mathrm{Ci}$ & $1.07 \times 10^{7}$ & $8.16 \times 10^{-1}$ \\
\hline $\mathrm{U}, \mathrm{kg}$ & $5.88 \times 10^{2}$ & $5.88 \times 10^{2}$ \\
\hline
\end{tabular}

\section{Evaluation of Scintillation Probe Profiles:}

We11 E13-12 monitors the 216-B-26 specific retention trench (figures $A-1$ and A-102). The scintillation probe profiles show near background levels of radiation (figure A-107). These data indicate breakthrough to the groundwater has not occurred at this site. 


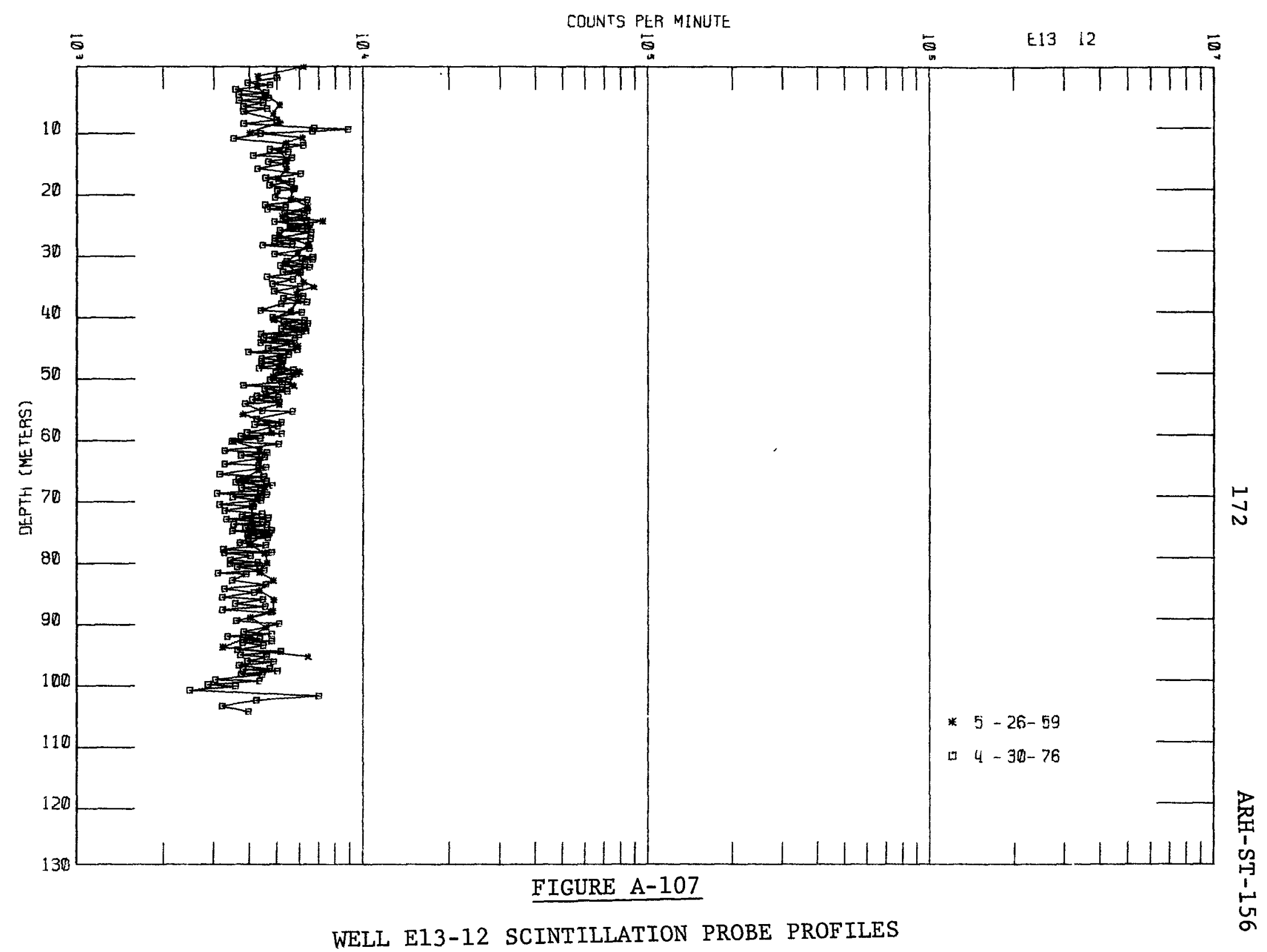




\section{6-B-28 Specific Retention Trench}

Description of Waste: Scavenged waste from uranium recovery (TBP solvent extraction) process in 221-U Building.

Service Dates: 1957

Waste volume: $5.05 \times 10^{6}$ ititers

Waste Inventory:

\begin{tabular}{|c|c|c|}
\hline & Total & Decay Thru June 1976 \\
\hline$P u, g$ & $5.60 \times 10^{0}$ & $5.60 \times 10^{0}$ \\
\hline Beta, Ci & $1.65 \times 10^{4}$ & $1.74 \times 10^{2}$ \\
\hline${ }^{90} \mathrm{Sr}, \mathrm{Ci}$ & $1.12 \times 10^{2}$ & $7.02 \times 10^{7}$ \\
\hline${ }^{106} \mathrm{Ru}, \mathrm{Ci}$ & $5.22 \times 10^{3}$ & $1.06 \times 10^{-2}$ \\
\hline${ }^{137} \mathrm{Cs}, \mathrm{Ci}$ & $2.30 \times 10^{1}$ & $1.49 \times 10^{1}$ \\
\hline${ }^{60} \mathrm{Co}, \mathrm{Ci}$ & $2.30 \times 10^{0}$ & $1.88 \times 10^{-1}$ \\
\hline $\mathrm{U}, \mathrm{kg}$ & $3.00 \times 10^{2}$ & $3.00 \times 10^{2}$ \\
\hline
\end{tabular}

Evaluation of Scintillation Probe Profiles:

We11s E13-3 and E13-19 monitor the 216-B-28 specific retention trench (figures $A-1$ and A-102). Radioactive contaminants detected at the ground surface in 1963 have decreased into background levels in We11 E13-19 (figures A-108 and A-109). In 1968 the zone of contamination is between 7.0 and 22.9 meters below the ground surface. Well E13-19 has not been logged since 1968 .

The scintillation probe profiles from 1959 and 1963 show the contaminant front has penetrated an additional 3.0 meters. Since 1963 continued drainage has effectively stopped, retaining the contaminants high in the sediment column, 94.4 meters above the water table. The radiation intensity in the zone of contamination has been decreasing by radionuclide decay. These data indicate breakthrough to the groundwater has not occurred at this site. 


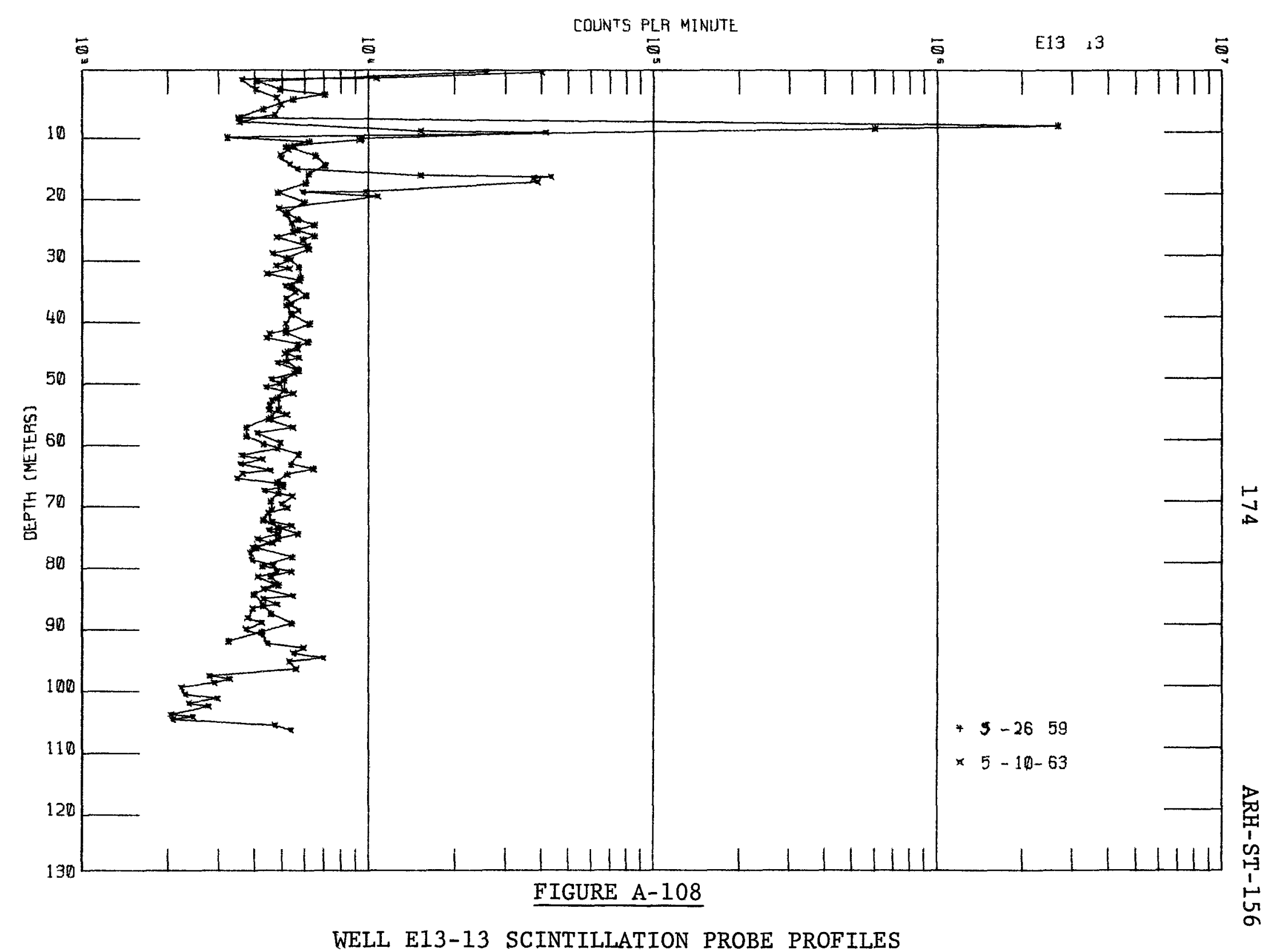




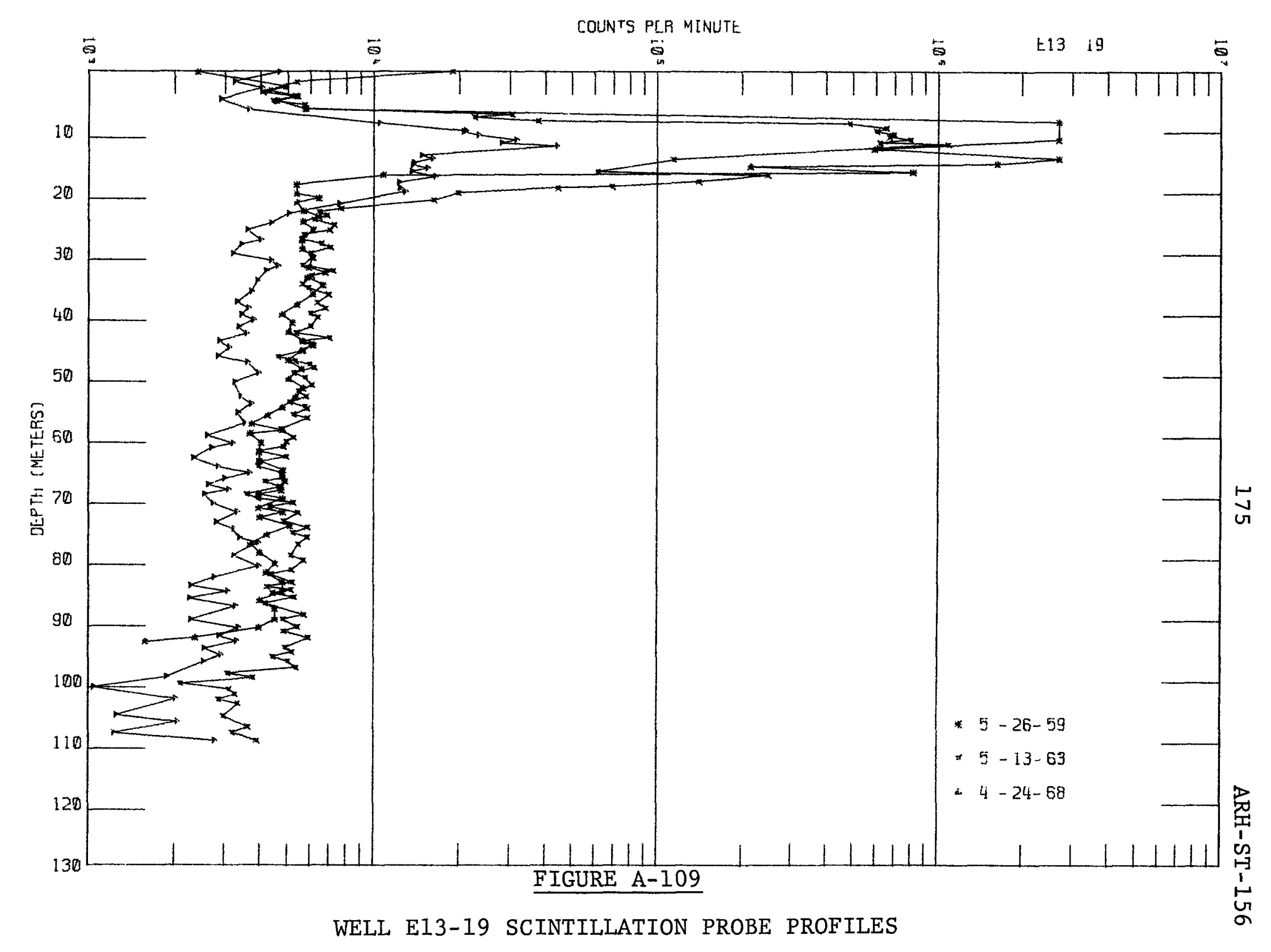




\section{6-B-29 Specific Retention Trench}

Description of Waste: Scavenged waste from uranium recovery (TBP solvent extraction) process in 221-U Building.

Service Dates: 1957

Waste Volume: $4.84 \times 10^{6}$ liters

Waste Inventory:

\begin{tabular}{ccc} 
& Total & Decay Thru June 1976 \\
\cline { 2 - 3 } $\mathrm{Pu}, \mathrm{g}$ & $1.10 \times 10^{0}$ & $1.10 \times 10^{0}$ \\
${ }_{\text {Beta, } \mathrm{Ci}}$ & $5.10 \times 10^{4}$ & $3.30 \times 10^{2}$ \\
${ }^{90} \mathrm{Sr}, \mathrm{Ci}$ & $1.92 \times 10^{2}$ & $1.20 \times 10^{2}$ \\
${ }^{106} \mathrm{Ru}, \mathrm{Ci}$ & $1.61 \times 10^{4}$ & $3.29 \times 10^{-2}$ \\
${ }^{137} \mathrm{Cs}, \mathrm{Ci}$ & $5.90 \times 10^{7}$ & $3.81 \times 10^{1}$ \\
${ }^{60} \mathrm{Co}, \mathrm{Ci}$ & $7.10 \times 10^{0}$ & $5.80 \times 10^{-1}$ \\
$\mathrm{U}, \mathrm{kg}$ & $3.44 \times 10^{2}$ & $3.44 \times 10^{2}$
\end{tabular}

\section{Evaluation of Scintillation Probe Profiles:}

We11 E13-14 monitors the 216-B-29 specific retention trench (figures $A-1$ and A-102). Near background levels of radiation have been detected in well E13-14 in 1976 (figure A-110).

The scintillation probe profiles show radioactive contaminants detected at the 12.2 meter depth has decreased in radiation intensity by radionuclide decay. No measurable migration of radionuclides has been detected in this well. These data indicate breakthrough to the groundwater has not occurred at this site. 
• .

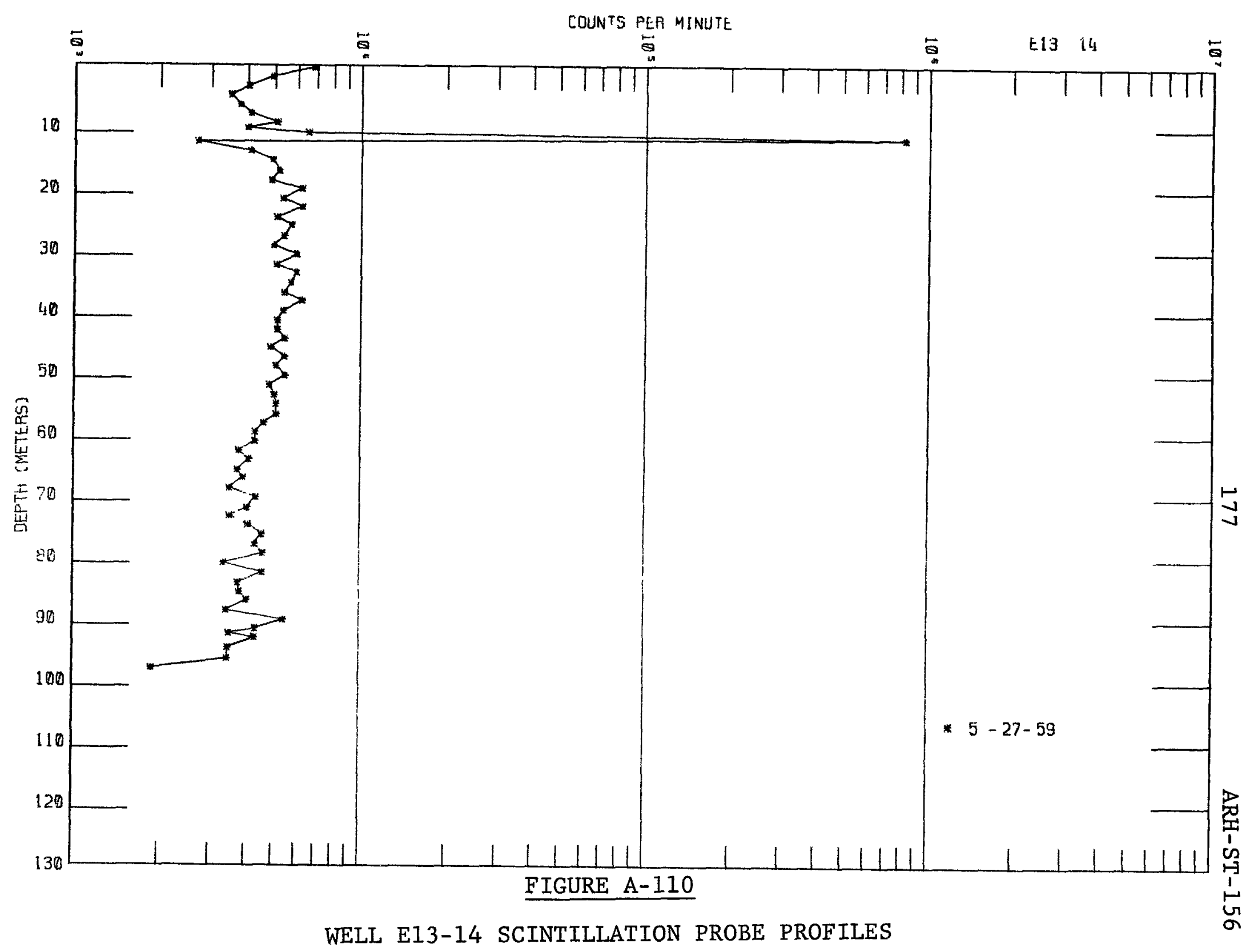




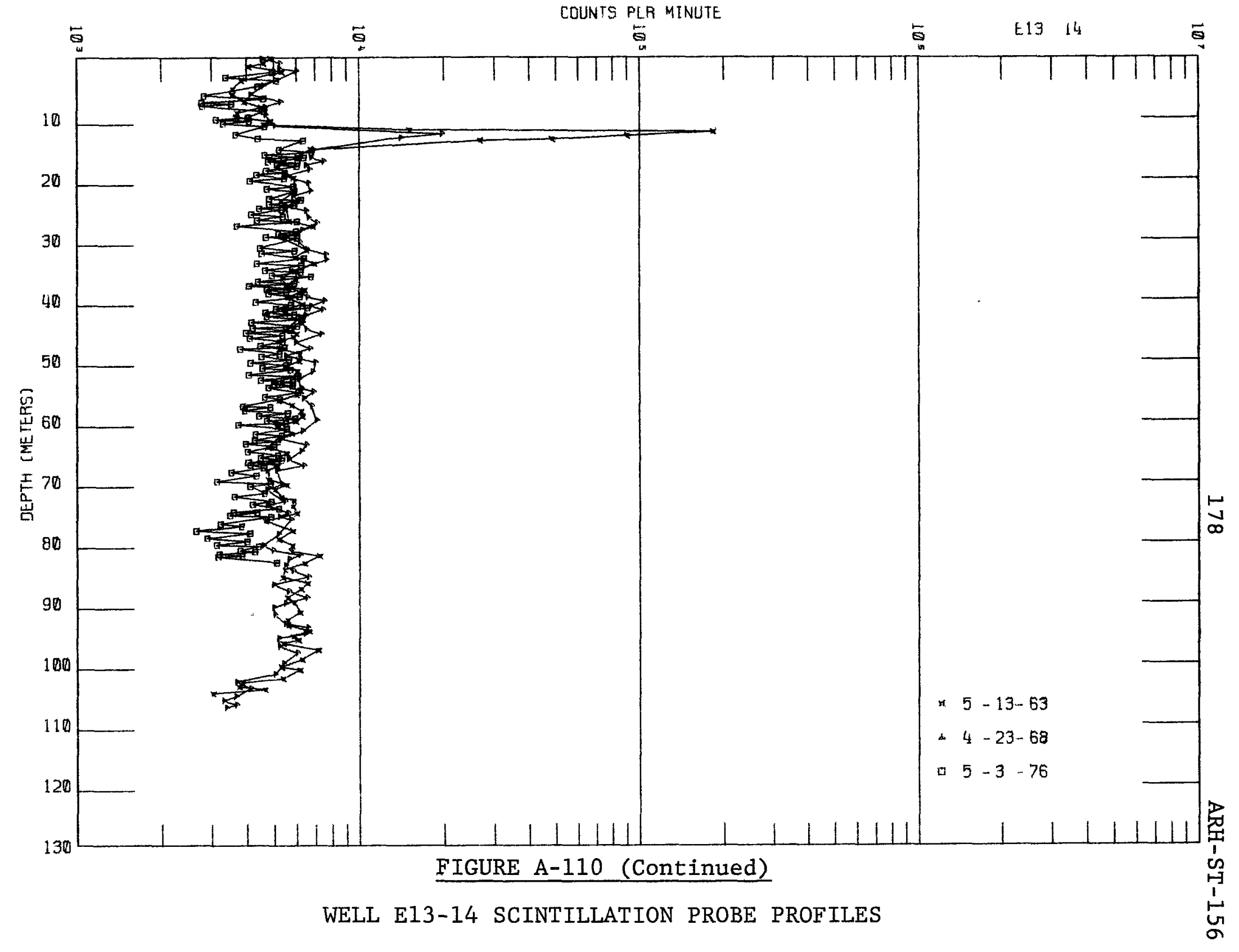


216-B-31 Specific Retention Trench

Description of Waste: Scavenged waste from uranium recovery (TBP solvent extraction) process in 221-U Building.

Service Dates: 1957

Waste Volume: $4.74 \times 10^{6}$ 1iters

Waste Inventory:

\begin{tabular}{|c|c|c|}
\hline & Total & Decay Thru June \\
\hline $\mathrm{Pu}, \mathrm{g}$ & $5.20 \times 10^{0}$ & $5.20 \times 10^{0}$ \\
\hline Beta, Ci & $1.92 \times 10^{4}$ & $3.03 \times 10^{2}$ \\
\hline${ }^{90} \mathrm{Sr}, \mathrm{Ci}$ & $2.09 \times 10^{2}$ & $1.31 \times 10^{2}$ \\
\hline${ }^{106} \mathrm{Ru}, \mathrm{Cj}$ & $6.09 \times 10^{3}$ & $1.24 \times 10^{-2}$ \\
\hline $137 \mathrm{Cs}, \mathrm{Ci}$ & $2.80 \times 10^{1}$ & $1.81 \times 10^{1}$ \\
\hline${ }^{60} \mathrm{Co}, \mathrm{Ci}$ & $2.70 \times 10^{0}$ & $2.21 \times 10^{-1}$ \\
\hline $\mathrm{u}, \mathrm{kg}$ & $1.22 \times 10^{2}$ & $1.22 \times 10^{2}$ \\
\hline
\end{tabular}

Evaluation of Scintillation Probe Profiles:

We11s E13-15 and E13-16 monitor the 216-B-31 specific retention trench (figures $A-1$ and $A-102$ ). Recent data shows that the zone of contamination in Well El3-15 is between 15.2 and 16.8 meters below the ground surface (figure A-111). In We11 E13-16 the zone of contamination is from 21.0 to 23.8 meters beneath the ground surface (figure A-112).

The scintillation probe profiles from Well E13-15 shows the count rate and the zone of contamination increasing through 1976. The profiles from Well El3-16 shows low levels of radiation slowly decreasing due to the presence of long lived radionuclides. Downward migration has not been detected in these wells other than the broader peak in Well E13-15. These data indicated breakthrough to the groundwater has not occurred at this site. 


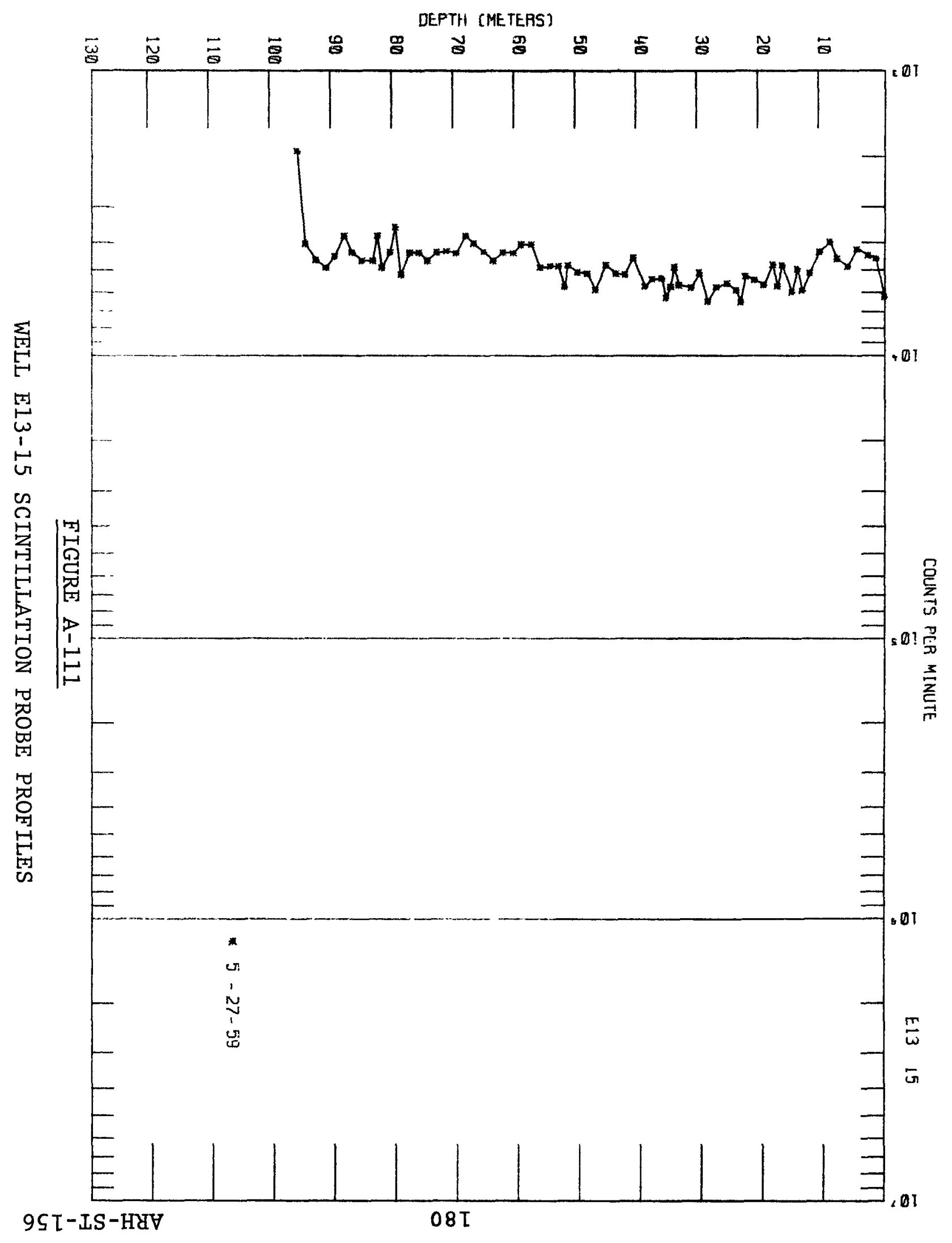


C

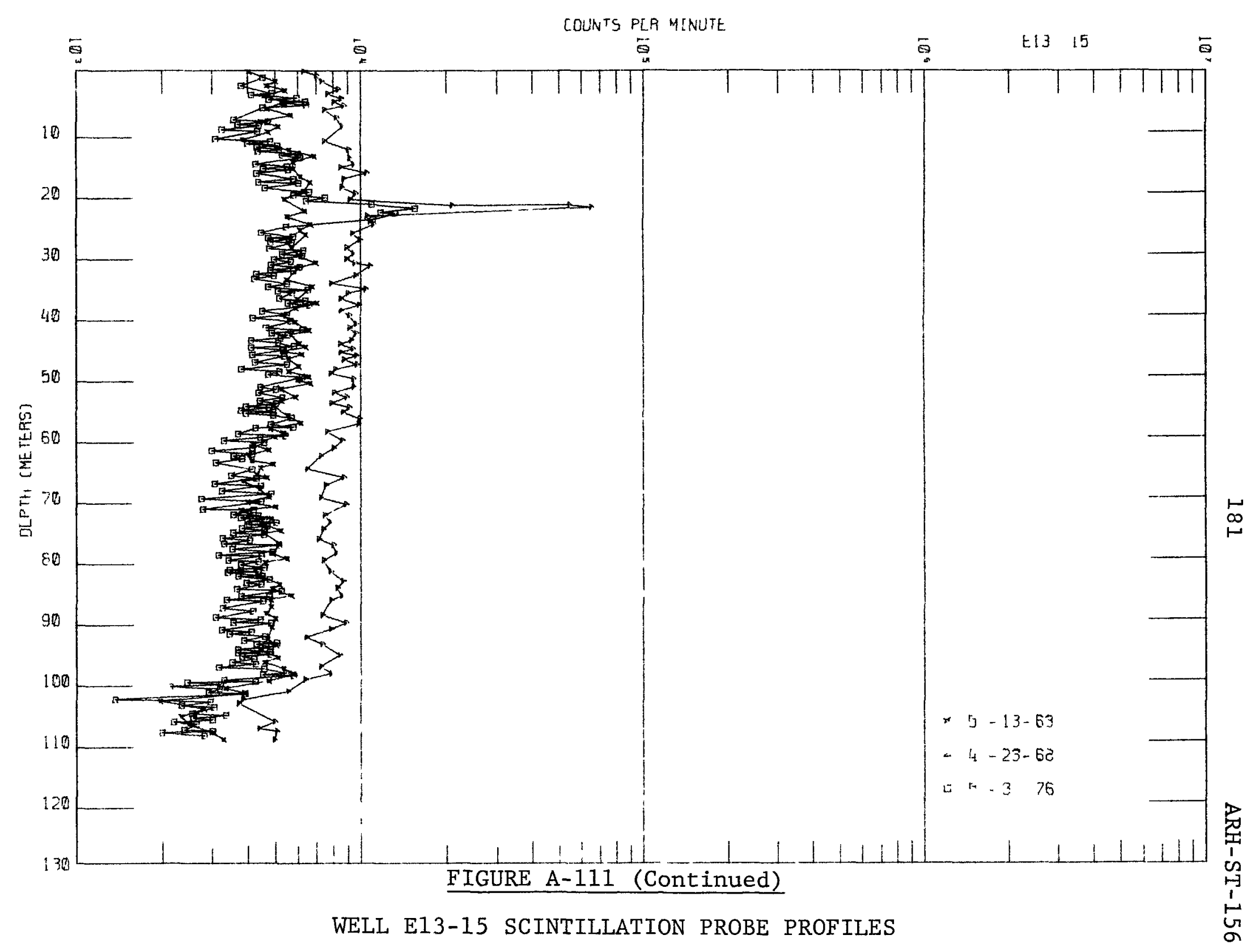




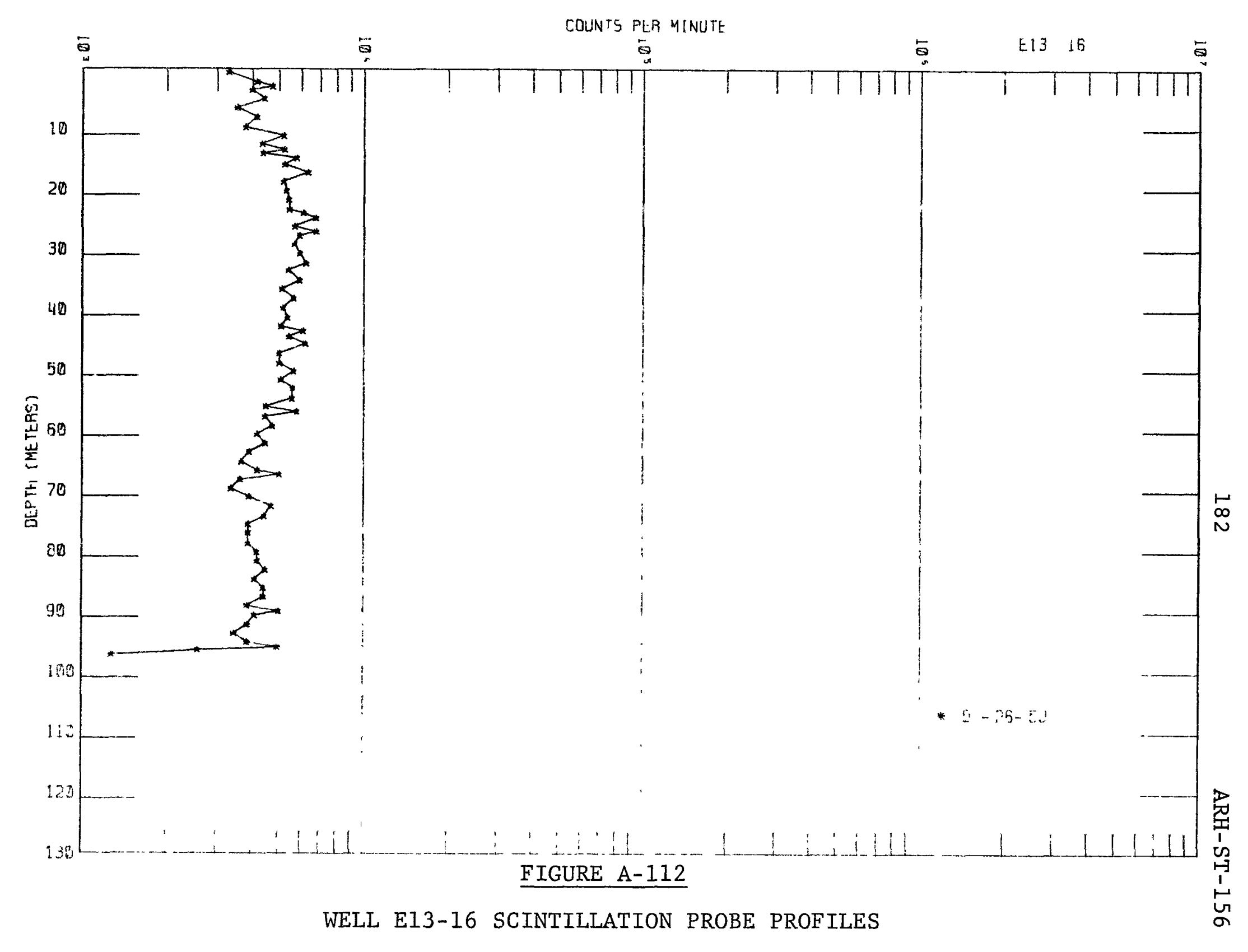


C

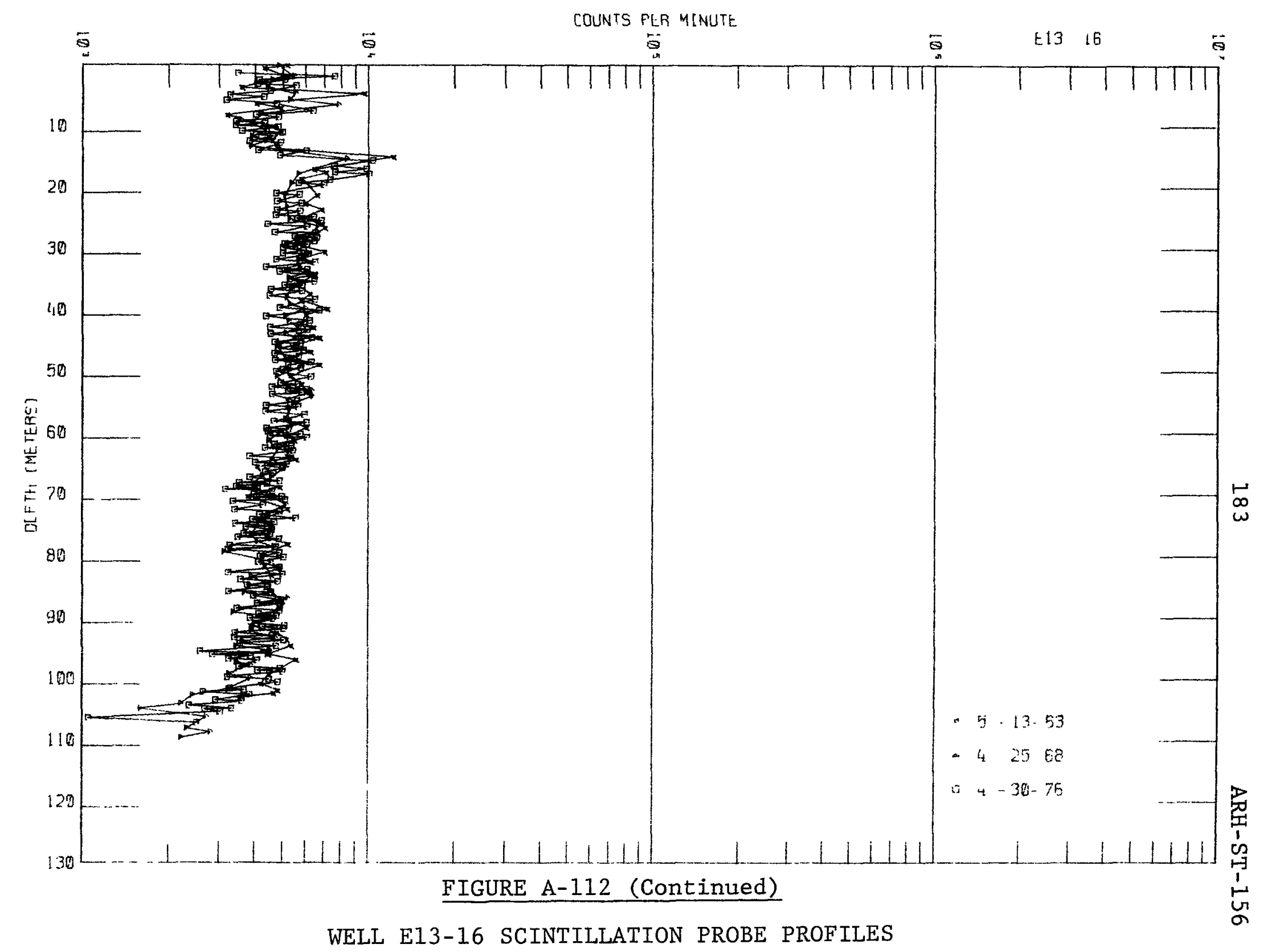




\section{6-B-34 Specific Retention Trench}

Description of Waste: Scavenged waste from uranium recovery (TBP solvent extraction) process in 221-U Building.

Service Dates: 1957

Waste Volume: $4.87 \times 10^{6}$ iiters

Waste Inventory:

\begin{tabular}{|c|c|c|}
\hline & Total & Decay Thru June 1976 \\
\hline $\mathrm{Pu}, \mathrm{g}$ & $5.70 \times 10^{0}$ & $5.70 \times 10^{0}$ \\
\hline Beta, $\mathrm{C} i$ & $4.36 \times 10^{3}$ & $7.38 \times 10^{7}$ \\
\hline${ }^{90} \mathrm{Sr}, \mathrm{Ci}$ & $4.10 \times 10^{7}$ & $2.57 \times 10^{7}$ \\
\hline${ }^{106} \mathrm{Ru}, \mathrm{Ci}$ & $1.38 \times 10^{3}$ & $2.81 \times 10^{-3}$ \\
\hline $137 \mathrm{Cs}, \mathrm{Ci}$ & $1.70 \times 10^{1}$ & $1.10 \times 10^{1}$ \\
\hline${ }^{60} \mathrm{Co}, \mathrm{Ci}$ & $6.00 \times 10^{-1}$ & $4.90 \times 10^{-2}$ \\
\hline $\mathrm{U}, \mathrm{kg}$ & $8.50 \times 10^{7}$ & $8.50 \times 10^{7}$ \\
\hline
\end{tabular}

Evaluation of Scintillation Probe Profiles:

We11s E13-10, E13-17 and E13-18 monitor the 216-B-34 specific retention trench (figures $A-1$ and A-102). Near background leve1s of radioactive contaminants are detected in the profiles from the 1976 logging operations (figures A-113 through A-115).

The scintillation probe profiles from Well El3-10 show radioactive contaminants detected at the 12.2 meter depth. Minor soil drainage has occurred between 1959 and 1968. The profiles from We11 E13-17 show background levels of radioactivity in 1959 and 1976. The peak at the 7.3 meter depth in we11 E13-18 has decreased in radiation intensity to near background by radionuclide decay. These data indicate breakthrough to the groundwater has not occurred at this site. 


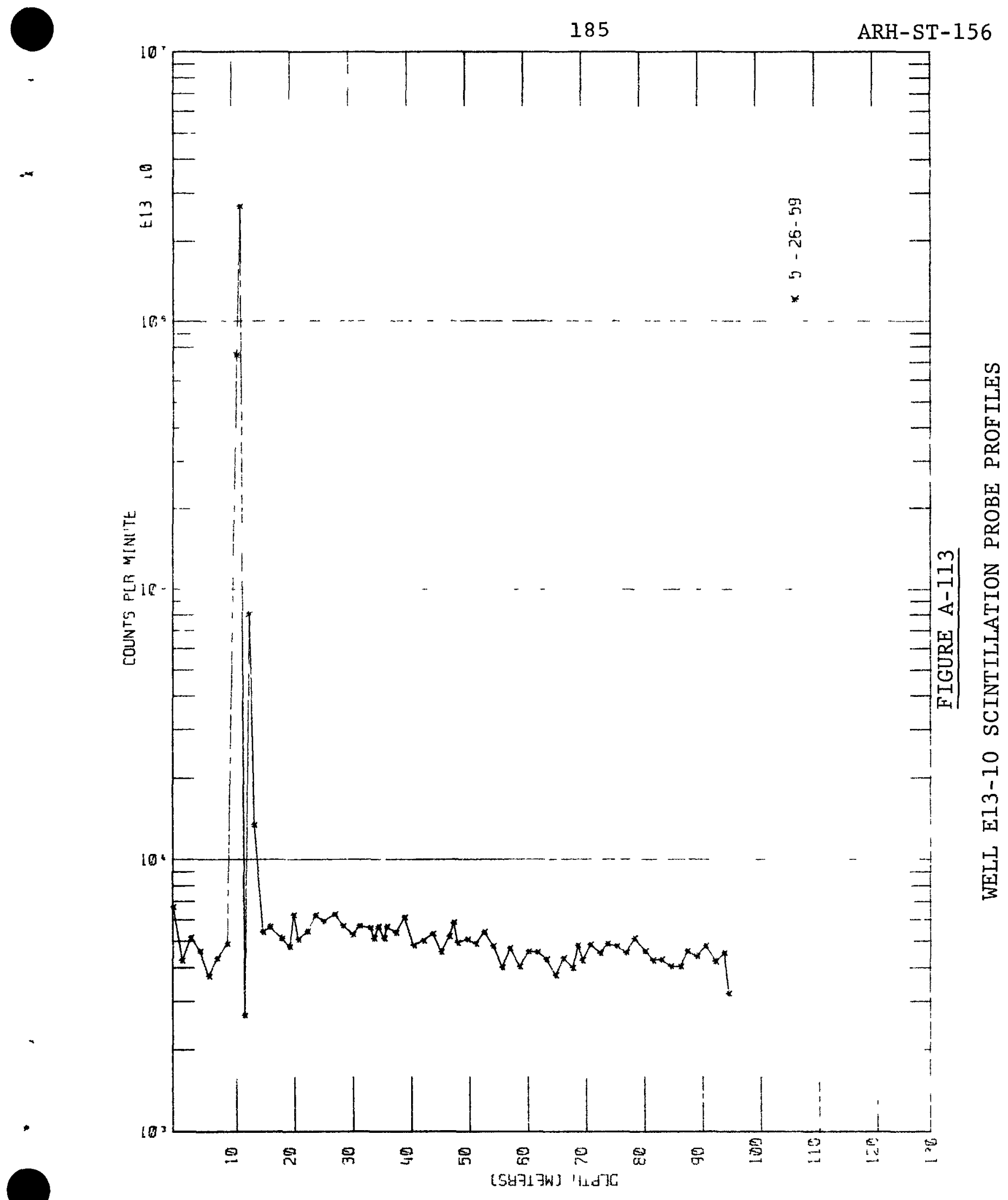




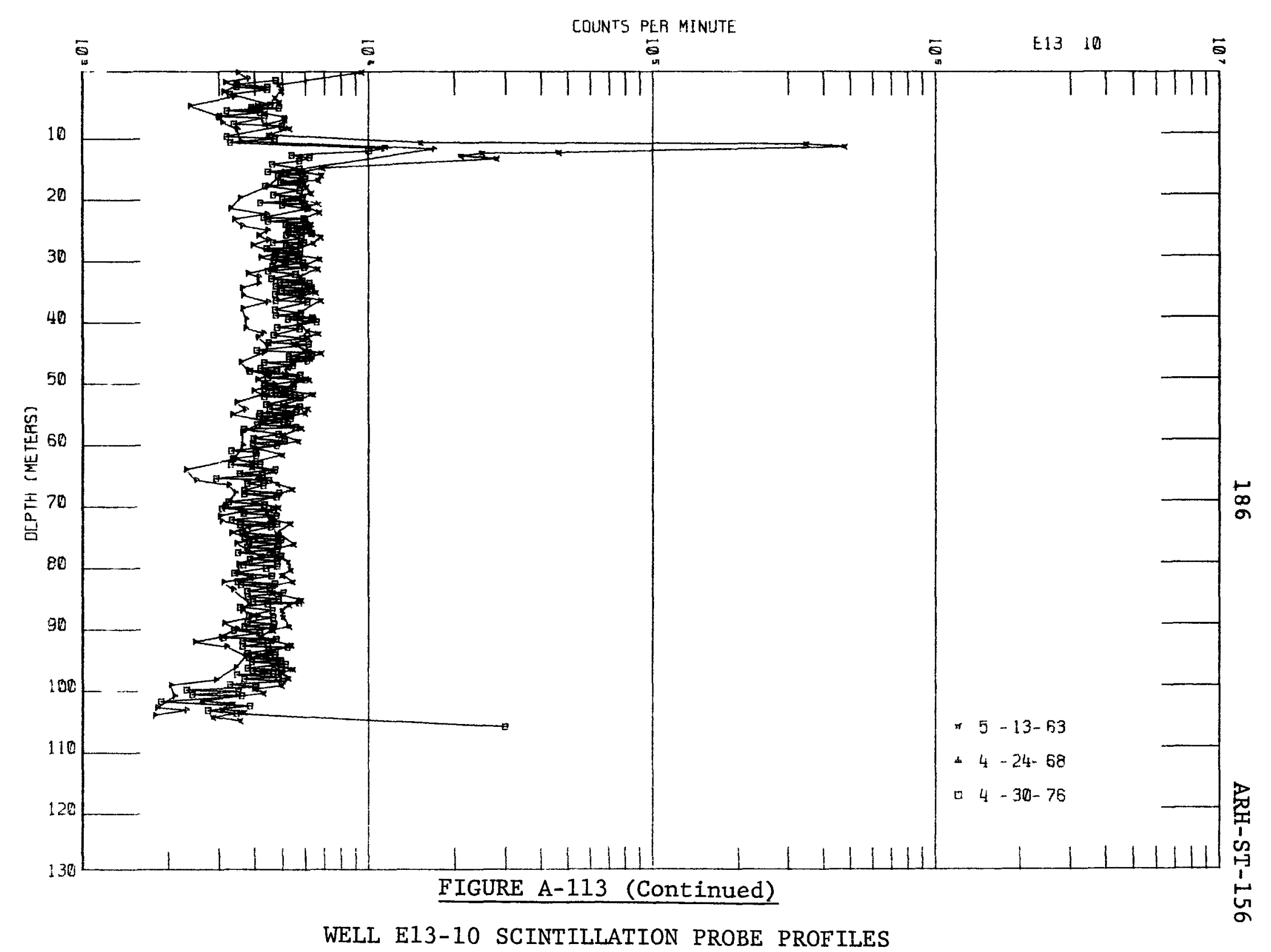


C $x$

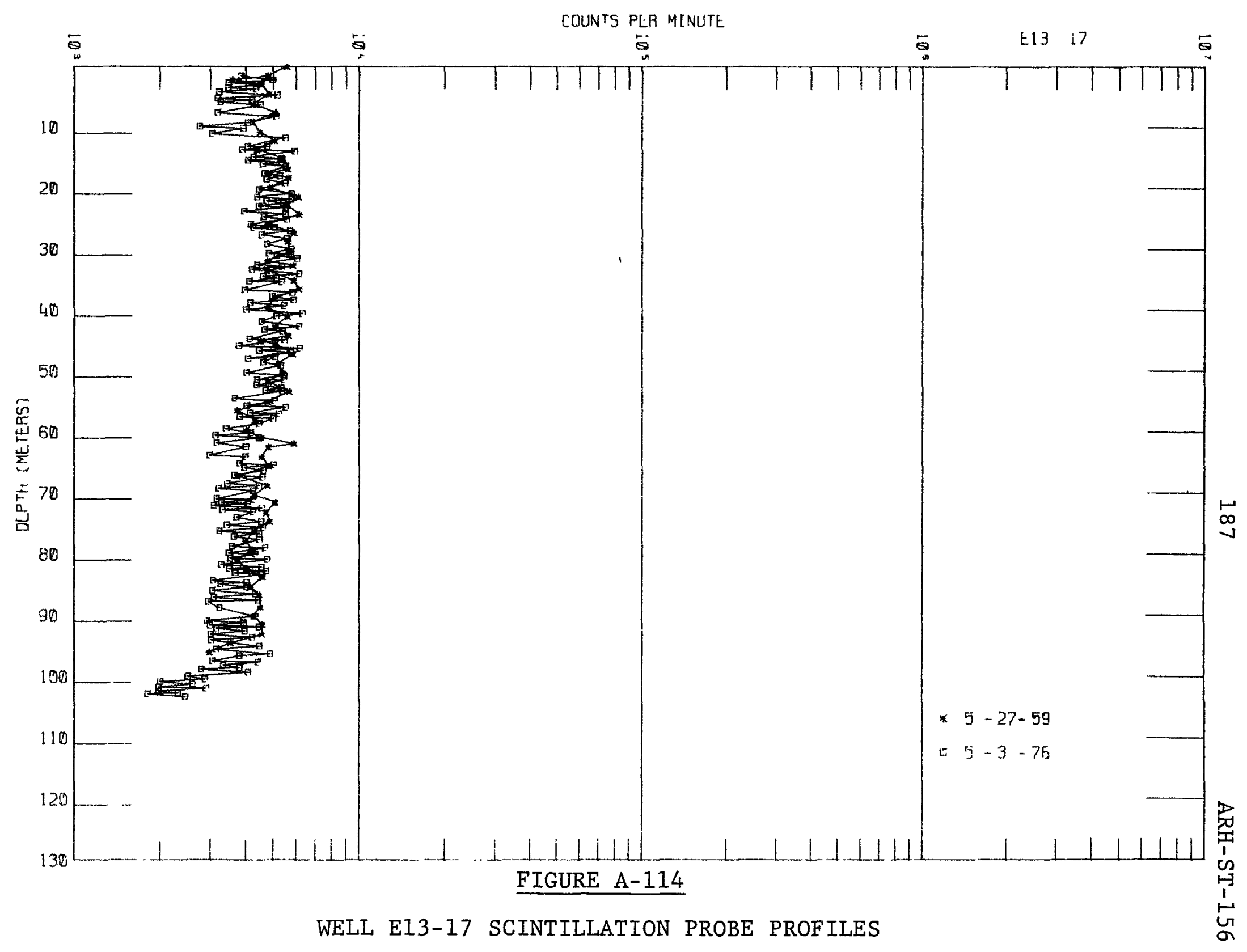


•

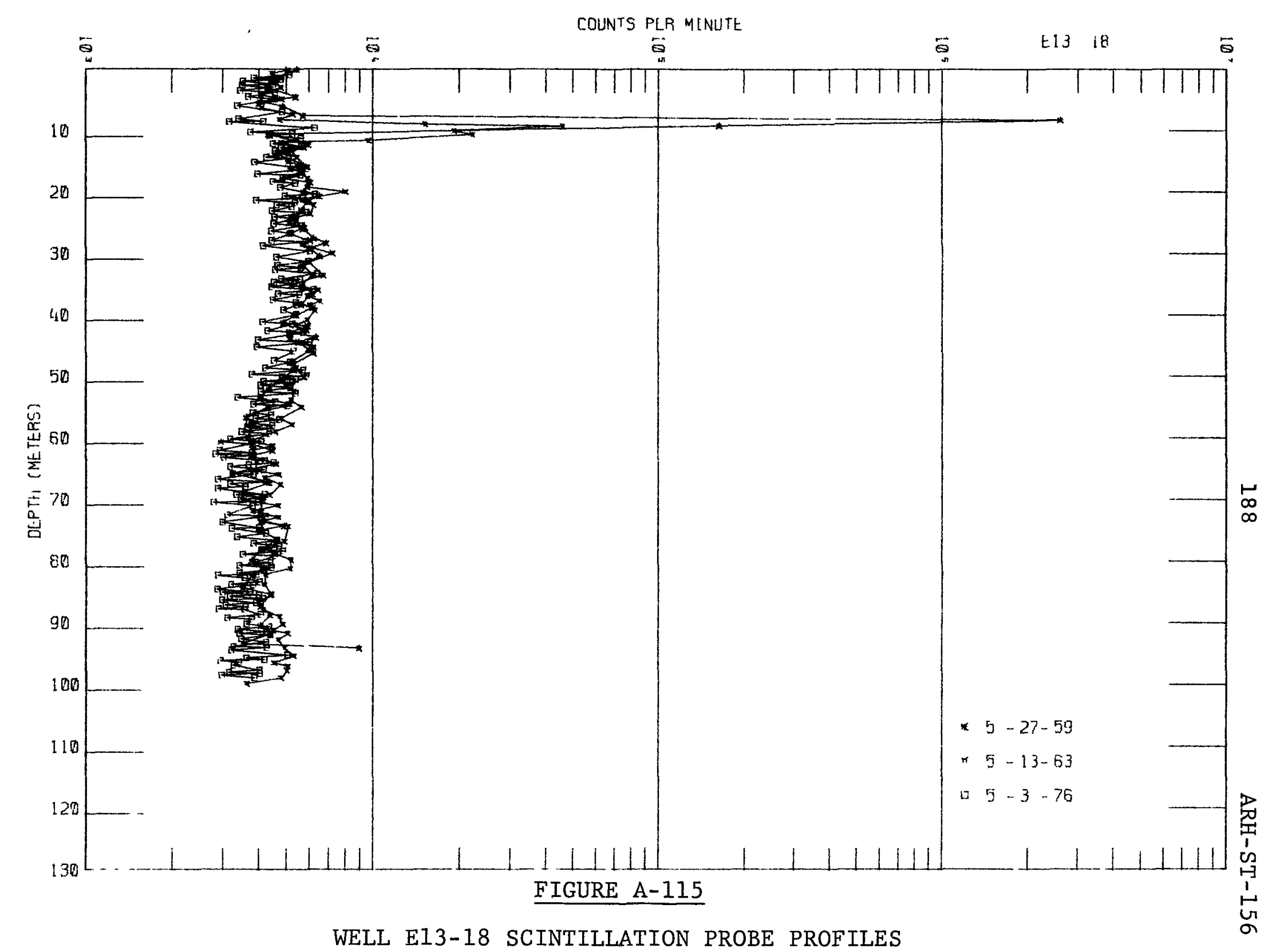


216-B-36 Specific Retention Trench

Description of Waste: First cycle supernatant waste from 221-B Building. Service Date: 1954

Waste Volume: $1.94 \times 10^{6}$ liters

Waste Inventory:

Total Decayed Thru June 1976

$\begin{array}{rll}\mathrm{Pu}, \mathrm{g} & 8.00 \times 10^{-1} & 8.00 \times 10^{-1} \\ \text { Beta, } \mathrm{Ci} & 3.54 \times 10^{3} & 1.46 \times 10^{3} \\ { }^{90} \mathrm{Sr}, \mathrm{Ci} & 4.85 \times 10^{2} & 2.82 \times 10^{2} \\ { }^{106} \mathrm{Ru}, \mathrm{Ci} & 4.71 \times 10^{2} & 1.21 \times 10^{-4} \\ { }^{137} \mathrm{Cs}, \mathrm{Ci} & 7.73 \times 10^{2} & 4.66 \times 10^{2} \\ { }^{60} \mathrm{Cs}, \mathrm{Ci} & 7.00 \times 10^{-2} & 3.85 \times 10^{-3} \\ \mathrm{U}, \mathrm{kg} & 1.60 \times 10^{1} & 1.60 \times 10^{1}\end{array}$

Evaluation of Scintillation Probe Profiles:

Wel1 E33-21 monitors the 216-B-36 specific retention trench (figures $A-1$ and $A-116)$. Most of the radioactive contaminants are detected from the ground surface to a depth of 16.8 below the ground surface (figure A-117). Below the 16.8 meter depth minor activity is detected which by 1976 has decreased to background by radionuclide decay.

On the basis of the scintillation probe profiles no measurable movement of radionuclides beneath the 216-B-36 crib is detected. These data indicate breakthrough to the ground waste has not occurred at this site. 
N45800

N45700

N45600

N45600

N45400

N45300

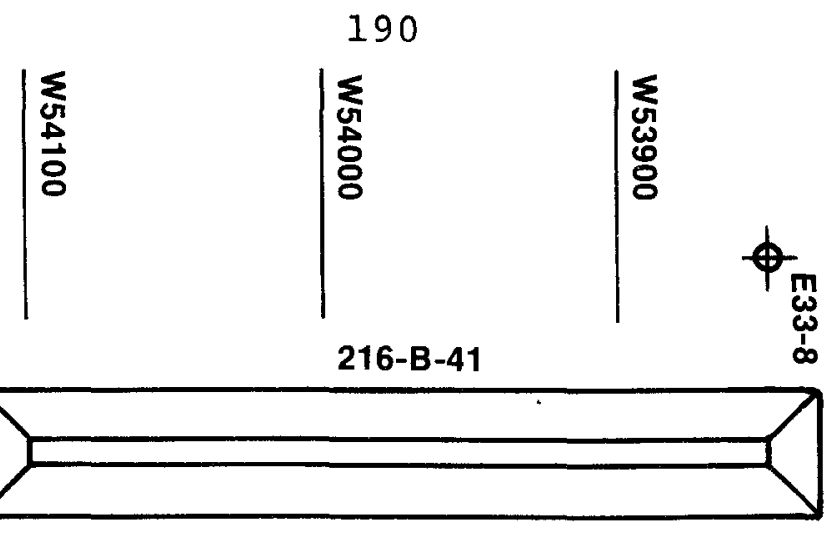

ARH-ST- 156

点

W

$\infty$

216-B-40

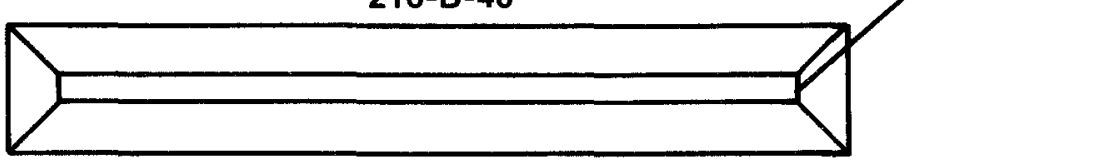

216-B-39

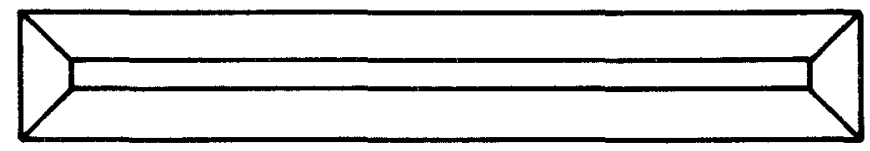

216-B-38

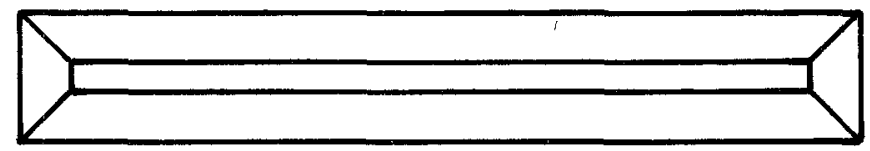

216-B-37
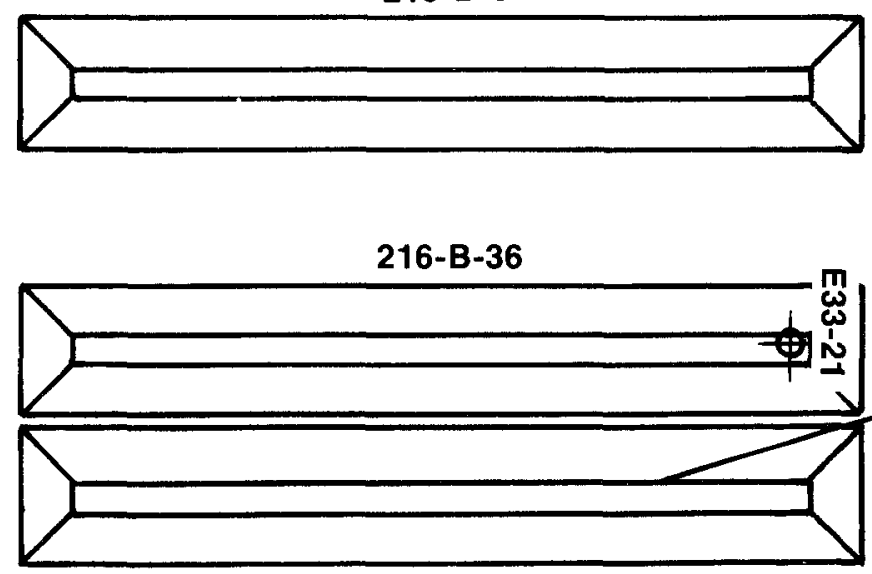

216-B-35

FIGURE A-116

216-B-35 THROUGH 216-B-41 CRIB PLOT PLANS 


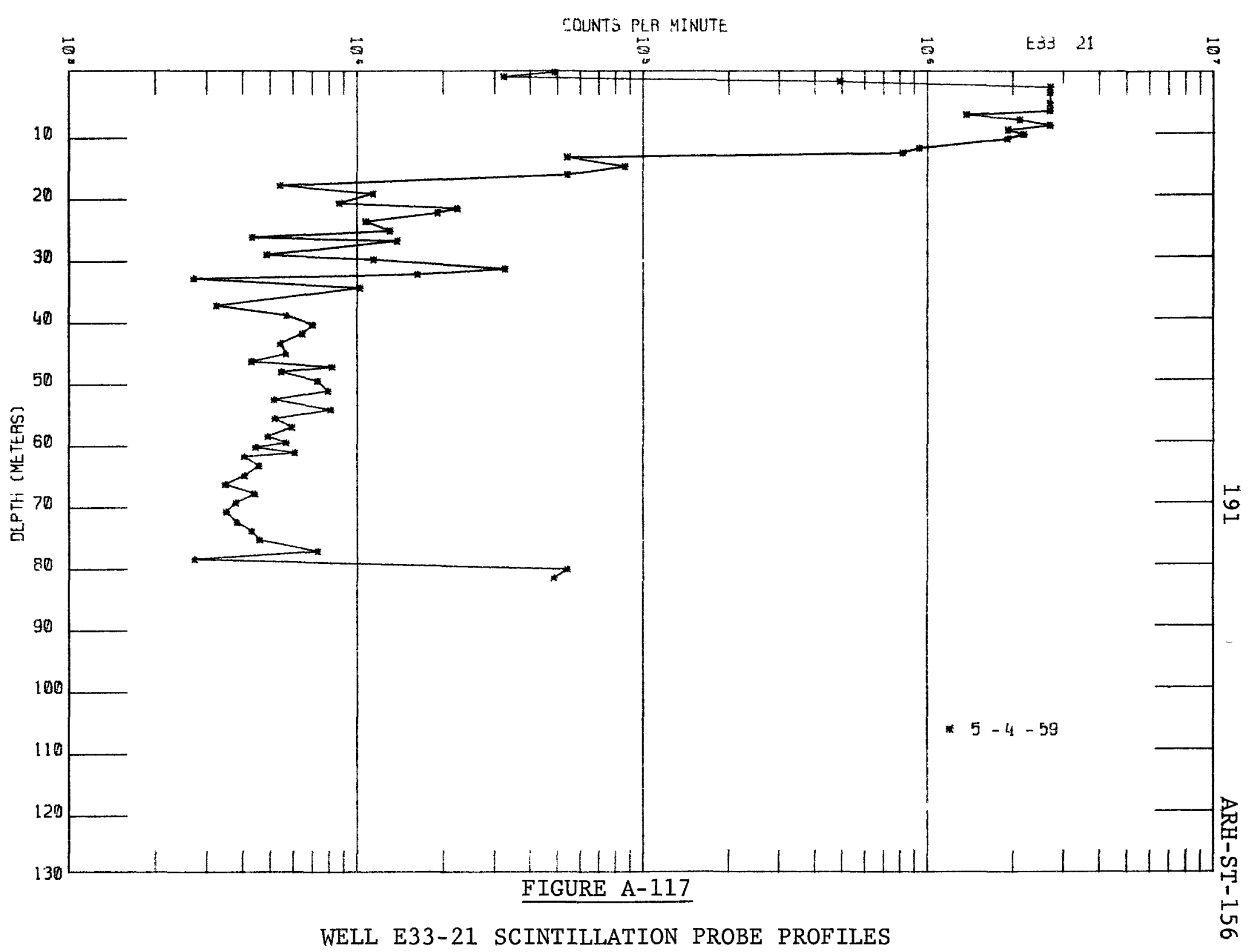


$+-$

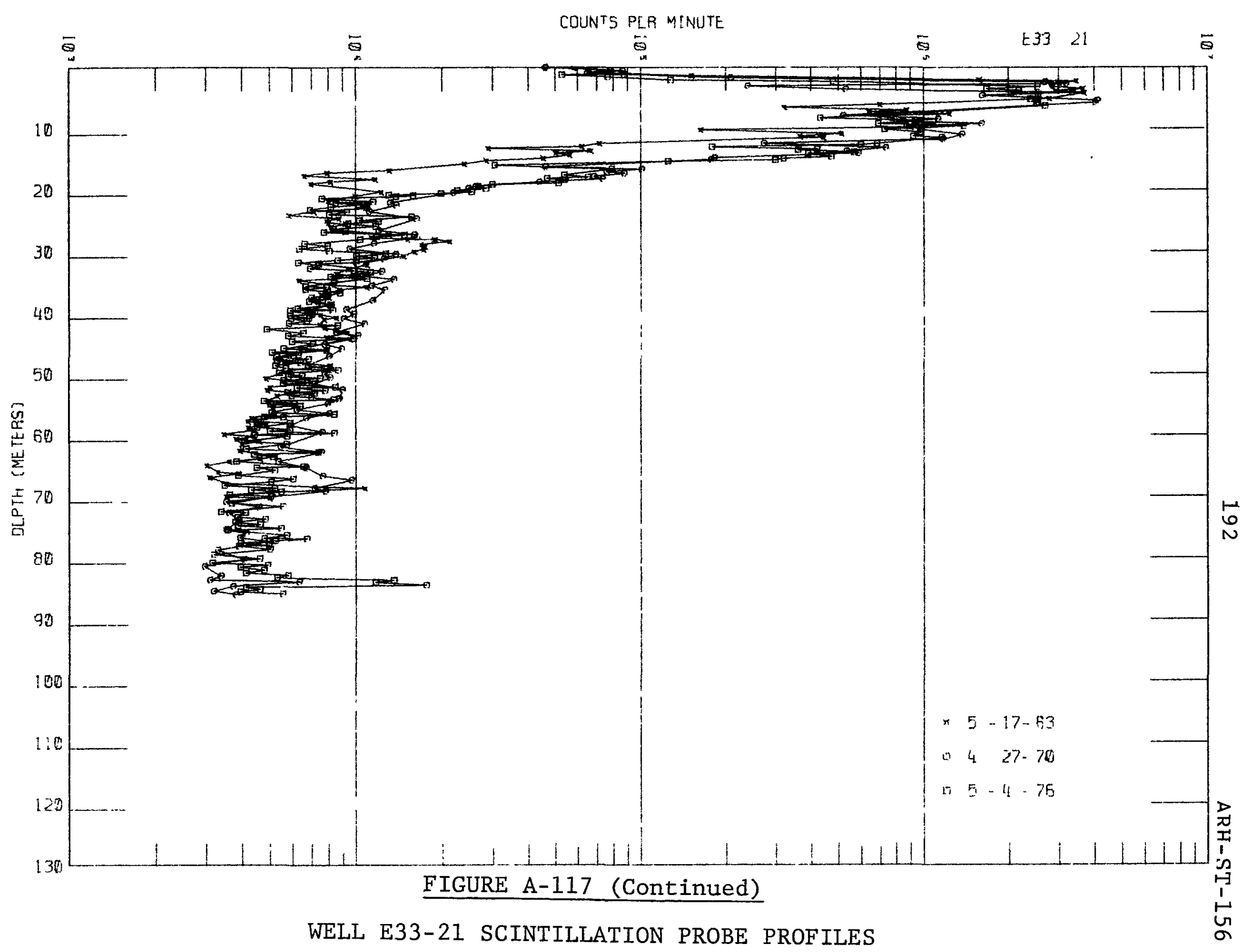




\section{6-B-41 Specific Retention Trench}

Description of Waste: First cycle supernatant waste from 221-B Building. Service Date: 1954

Waste Volume: $1.44 \times 10^{6}$ liters

Waste Inventory:

\begin{tabular}{|c|c|c|}
\hline & Total & Decayed thru June 1976 \\
\hline $\mathrm{Pu}, \mathrm{g}$ & $3.00 \times 10^{-1}$ & $3.00 \times 10^{-1}$ \\
\hline Beta, $\mathrm{C} j$ & $2.10 \times 10^{3}$ & $1.08 \times 10^{3}$ \\
\hline${ }^{90} \mathrm{Sr}, \mathrm{Ci}$ & $4.70 \times 10^{7}$ & $2.74 \times 10^{1}$ \\
\hline${ }^{106} \mathrm{Ru}, \mathrm{Ci}$ & $1.31 \times 10^{2}$ & $3.37 \times 10^{-5}$ \\
\hline${ }^{137} \mathrm{Cs}, \mathrm{Ci}$ & $8.90 \times 10^{2}$ & $5.36 \times 10^{2}$ \\
\hline${ }^{60} \mathrm{Co}, \mathrm{Ci}$ & $<1.00 \times 10^{-2}$ & $<5.50 \times 10^{-4}$ \\
\hline $\mathrm{U}, \mathrm{kg}$ & $7.50 \times 10^{0}$ & $7.50 \times 10^{0}$ \\
\hline
\end{tabular}

Evaluation of Scintillation Probe Profiles:

We11 E33-8 monitors the 216-B-41 specific retention trench (figures $A-1$ and A-116). Radioactive contaminants are detected between the 7.1 and 18.9 meter depths below the ground surface (figure A-118). The scintillation probe profiles indicate breakthrough to the groundwater has not occurred at this site. 


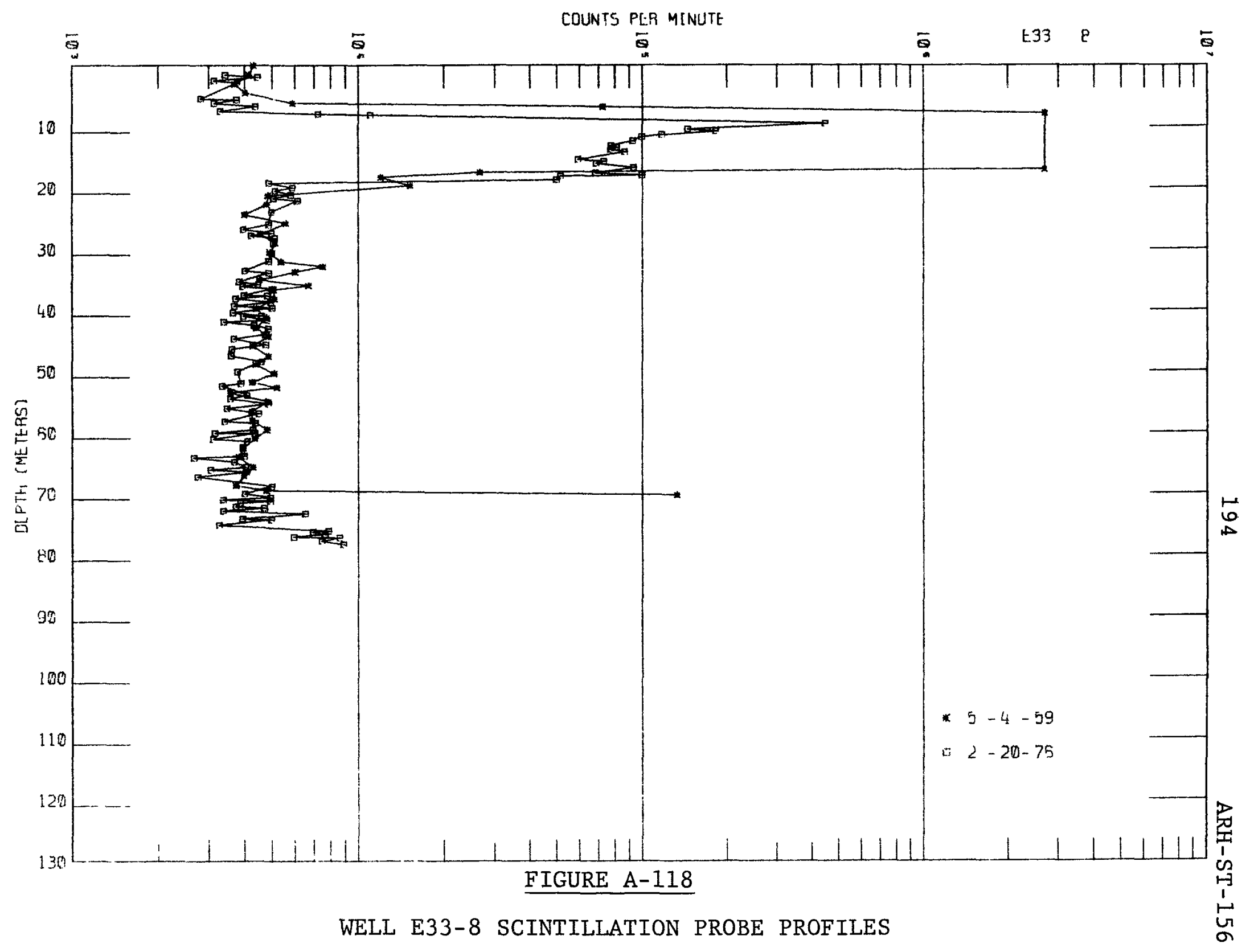


Description of Waste: Scavenged waste from uranium recovery (TBP solvent extraction) process in 221-U.

Service Date: 1954

Waste Volume: $2.12 \times 10^{6}$ liters

Waste Inventory:

\begin{tabular}{rcc} 
& Total & Decayed thru June 1976 \\
\cline { 2 - 3 } $\mathrm{Pu}, \mathrm{g}$ & $5.00 \times 10^{-1}$ & $5.00 \times 10^{-1}$ \\
$\mathrm{Beta}^{\mathrm{B}} \mathrm{Ci}$ & $3.52 \times 10^{3}$ & $1.98 \times 10^{3}$ \\
${ }^{90} \mathrm{Sr}, \mathrm{Ci}$ & $1.40 \times 10^{3}$ & $8.15 \times 10^{2}$ \\
${ }^{106} \mathrm{Ru}, \mathrm{Ci}$ & $5.00 \times 10^{1}$ & $1.29 \times 10^{-5}$ \\
${ }^{137} \mathrm{Cs}, \mathrm{Ci}$ & $3.00 \times 10^{2}$ & $1.81 \times 10^{2}$ \\
${ }^{60} \mathrm{Co}, \mathrm{Ci}$ & $1.00 \times 10^{0}$ & $5.50 \times 10^{-2}$ \\
$\mathrm{U}, \mathrm{kg}$ & $1.36 \times 10^{1}$ & $1.36 \times 10^{-1}$
\end{tabular}

Evaluation of Scintillation Probe Profiles:

Well E33-1 monitors the 216-B-43 crib (figures $A-1$ and A-119). In 1976, 22 years after waste disposal to the crib was terminated, radioactive contaminants are detected 7.0 meters below the ground surface to the water table (figure A-120). The radiation intensity in the zone of contamination is slowly decreasing indicating the presence of long-lived radionuclides throughout the contaminated sediment column.

On the basis of the scintillation probe profiles no measurable movement of radionuclides beneath the $216-\mathrm{B}-43 \mathrm{crib}$ is detected. These data indicate breakthrough to the groundwater could have occurred at this site. 


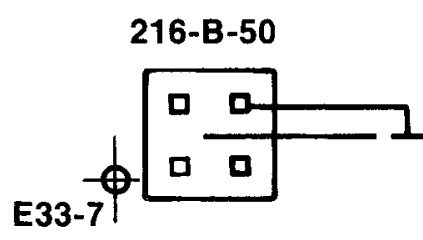

N46500

N46400

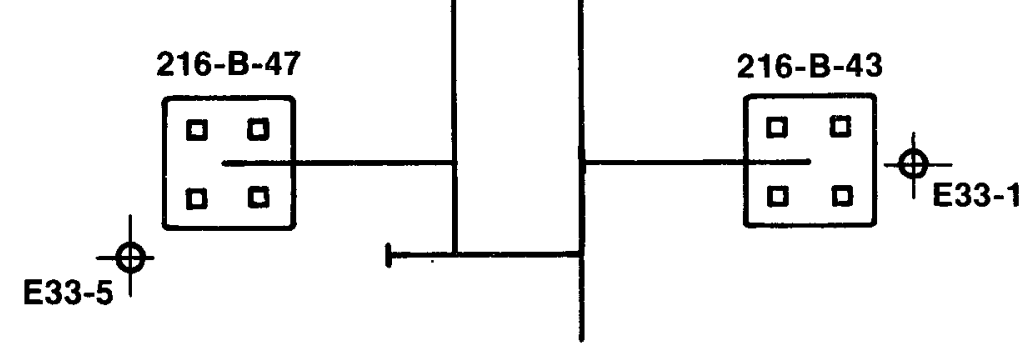

N46300

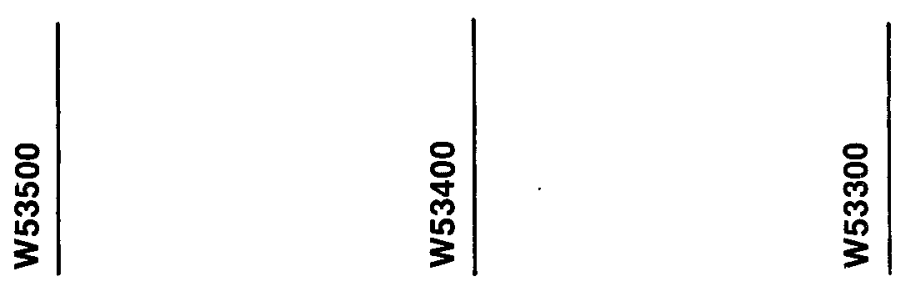

FIGURE A-119

216-B-43 THROUGH 216-B-50 CRIB PLOT PLANS 


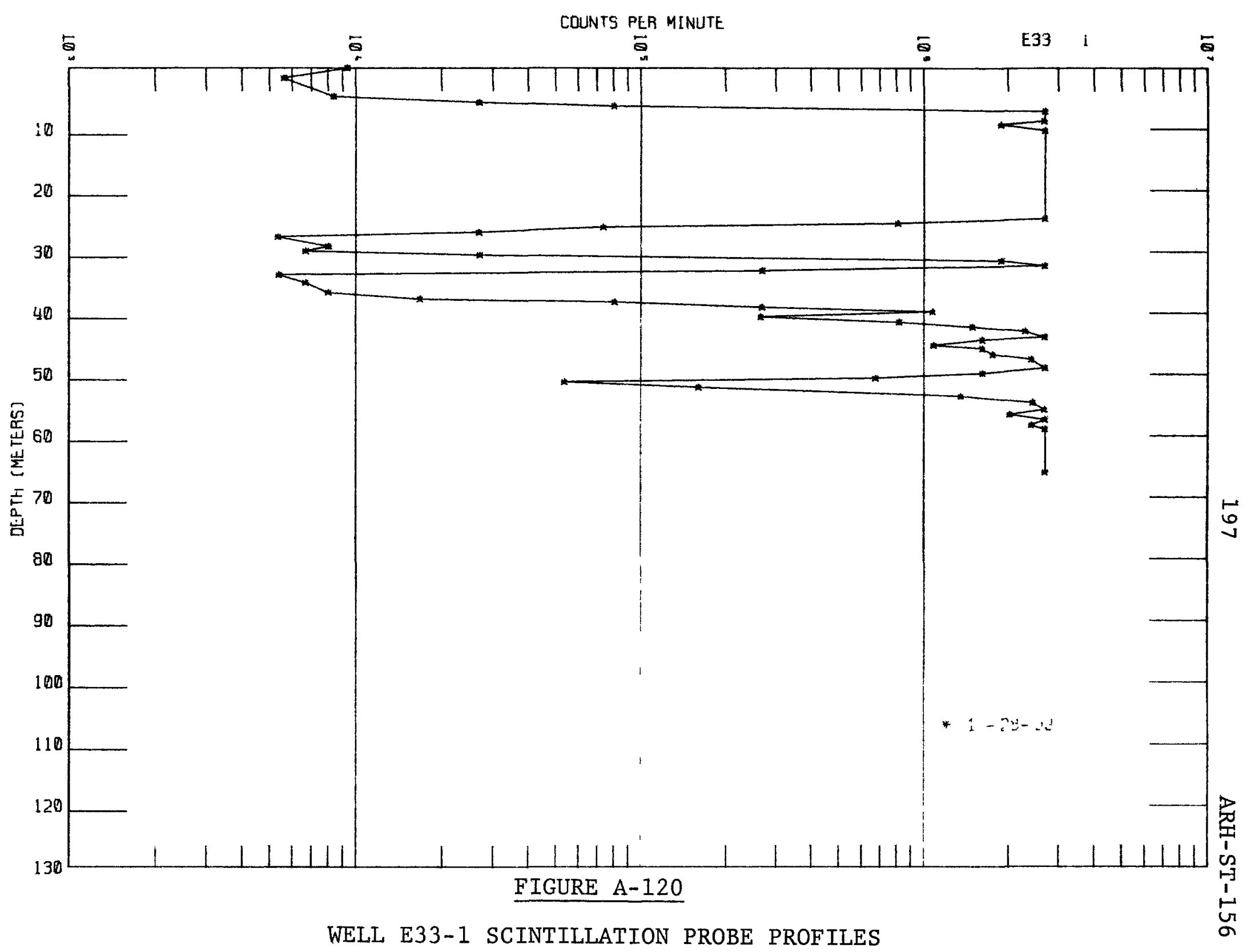




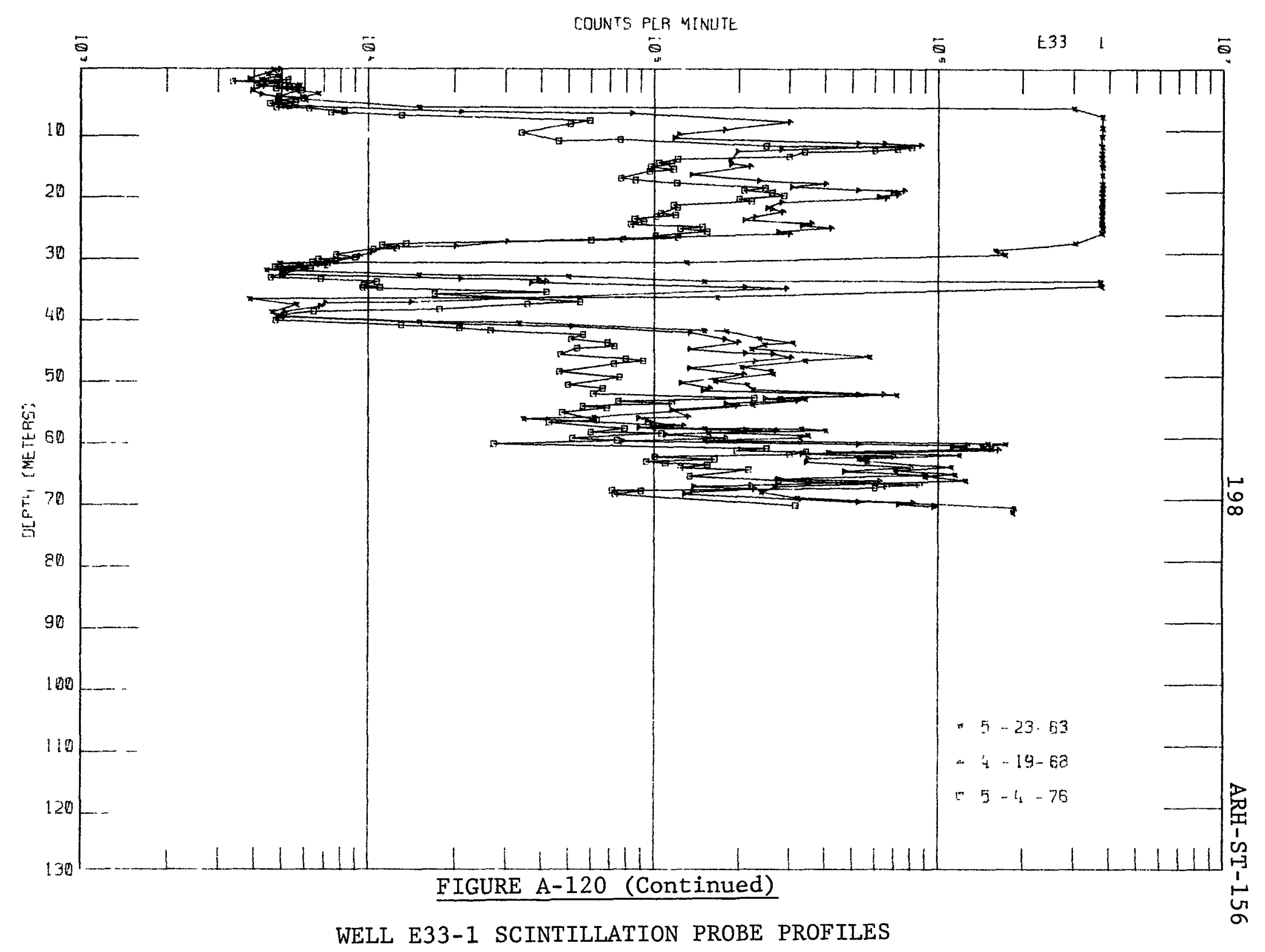


Description of Waste: Scavenged waste from uranium recovery (TBP solvent extraction) process in 221-U.

Service Dates: 1954 to 1955

Waste Volume: $5.60 \times 10^{6}$ liters

Waste Inventory:

Total Decayed thru June 1976

$\begin{array}{rll}\mathrm{Pu}, \mathrm{g} & 1.50 \times 10^{1} & 1.50 \times 10^{7} \\ \text { Beta, } \mathrm{Ci} & 2.20 \times 10^{4} & 4.22 \times 10^{3} \\ { }^{90} \mathrm{Sr}, \mathrm{Ci} & 2.90 \times 10^{3} & 1.70 \times 10^{3} \\ { }^{106} \mathrm{Ru}, \mathrm{Ci} & 5.50 \times 10^{3} & 2.60 \times 10^{-3} \\ { }^{137} \mathrm{Cs}, \mathrm{Ci} & 7.00 \times 10^{2} & 4.29 \times 10^{2} \\ { }^{60} \mathrm{Co}, \mathrm{Ci} & 5.00 \times 10^{0} & 2.97 \times 10^{-1} \\ \mathrm{U}, \mathrm{kg} & 2.27 \times 10^{0} & 2.27 \times 10^{0}\end{array}$

Evaluation of Scintillation Probe Profiles:

We11 E33-2 monitors the 216-B-44 crib (figures $A-1$ and A-119). In 1976, 21 years after waste disposal to the crib was terminated, radioactive contaminants are detected from a depth of 12.8 meters below the ground surface to the water table (figure A-121). The radiation intensity in the zone of contamination has been decreasing by radionuclide decay.

On the basis of the scintillation probe profiles no measurable movement of radionuclides beneath the $216-\mathrm{B}-43 \mathrm{crib}$ is detected. These data indicate breakthrough to the groundwater could have occurred at this site. 


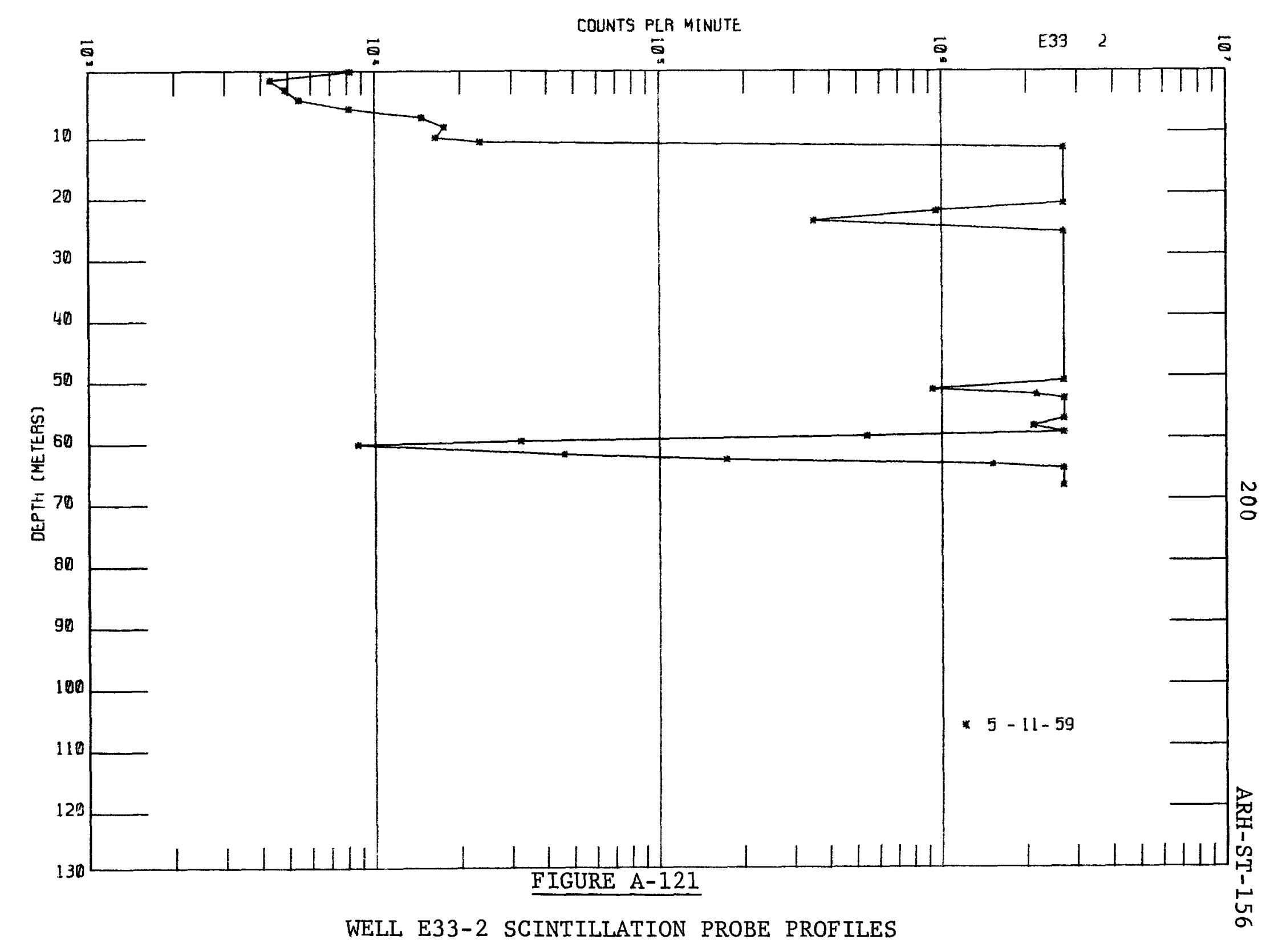


, ,

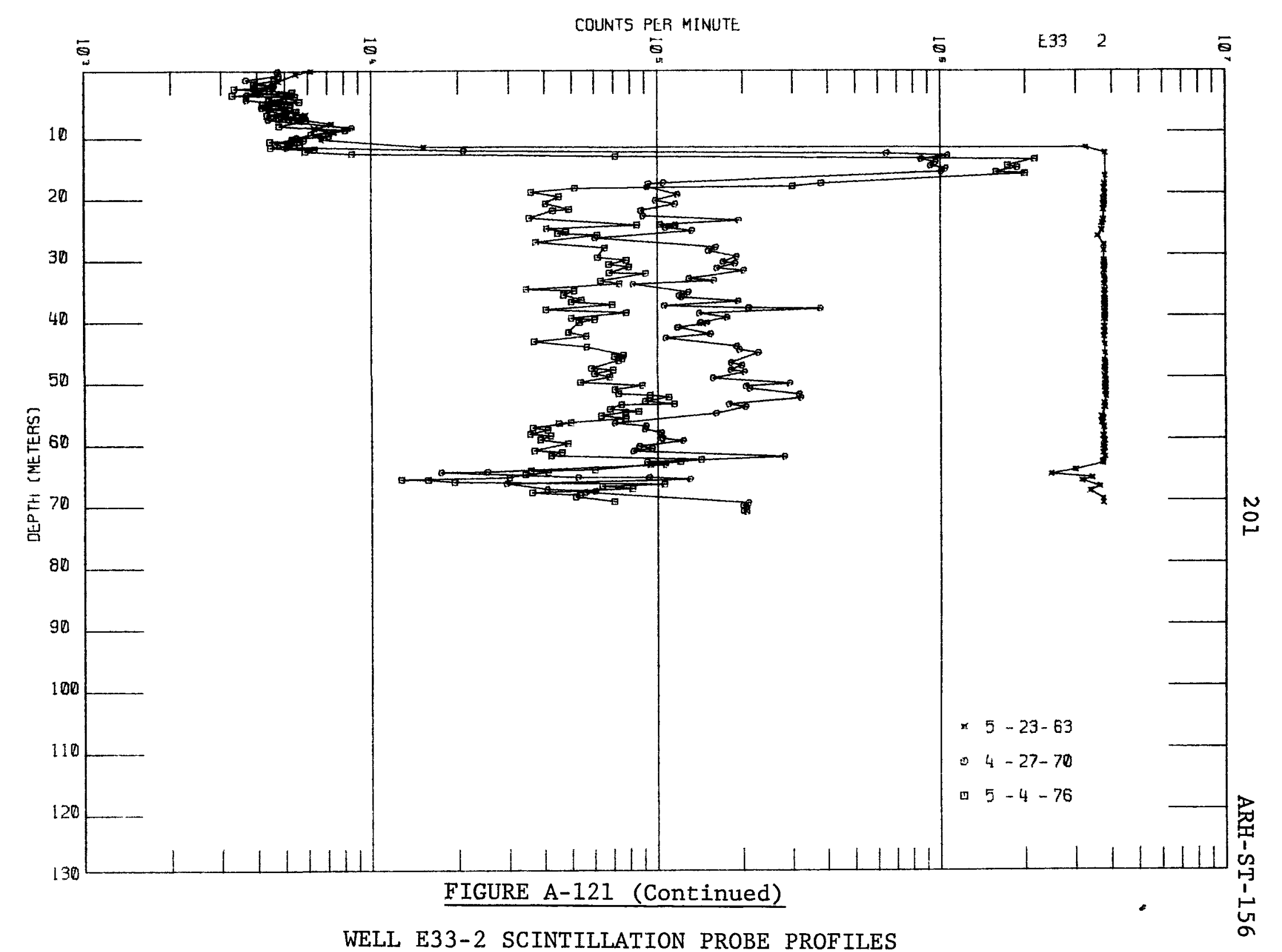




\section{6-B-45 Crib}

Description of Waste: Scavenged waste from uranium recovery (TBP solvent extraction) process in 221-U.

Service Date: 1955

Waste Volume: $4.92 \times 10^{6}$ liters

Waste Inventory:

\begin{tabular}{|c|c|c|}
\hline & Total & Decayed thru June 1976 \\
\hline $\mathrm{Pu}, \mathrm{g}$ & $1.00 \times 10^{7}$ & $1.00 \times 10^{7}$ \\
\hline Beta, Ci & $5.30 \times 10^{4}$ & $5.13 \times 10^{3}$ \\
\hline${ }^{90} \mathrm{Sr}, \mathrm{Ci}$ & $2.80 \times 10^{3}$ & $1.67 \times 10^{3}$ \\
\hline${ }^{106} \mathrm{Ru}, \mathrm{Ci}$ & $1.70 \times 10^{4}$ & $8.71 \times 10^{-3}$ \\
\hline${ }^{137} \mathrm{Cs}, \mathrm{Ci}$ & $1.50 \times 10^{3}$ & $9.25 \times 10^{2}$ \\
\hline${ }^{60} \mathrm{Co}, \mathrm{Ci}$ & $5.00 \times 10^{0}$ & $3.14 \times 10^{-1}$ \\
\hline $\mathrm{U}, \mathrm{kg}$ & $6.80 \times 10^{0}$ & $6.80 \times 10^{0}$ \\
\hline
\end{tabular}

Evaluation of Scintillation Probe Profiles:

Wel1s E33-3 and E33-22 monitor the 216-B-45 crib (figures A-1 and A-119). In 1976, 21 years after waste disposal to the crib was terminated, radioactive contaminants are detected from the ground surface in we11 E33-22 and from 7.9 meters below the ground surface in well E33-3 to the water table (figures $\mathrm{A}-122$ and $\mathrm{A}-123$ ). The radiation intensity in the zone of contamination is slowly decreasing indicating the presence of long-lived radionuclides throughout the contaminated sediment column.

On the basis of the scintillation probe profiles no measureable movement of radionuclides beneath the $216-\mathrm{B}-45 \mathrm{crib}$ is detected. These data indicate breakthrough to the groundwater could have occurred at this site. 


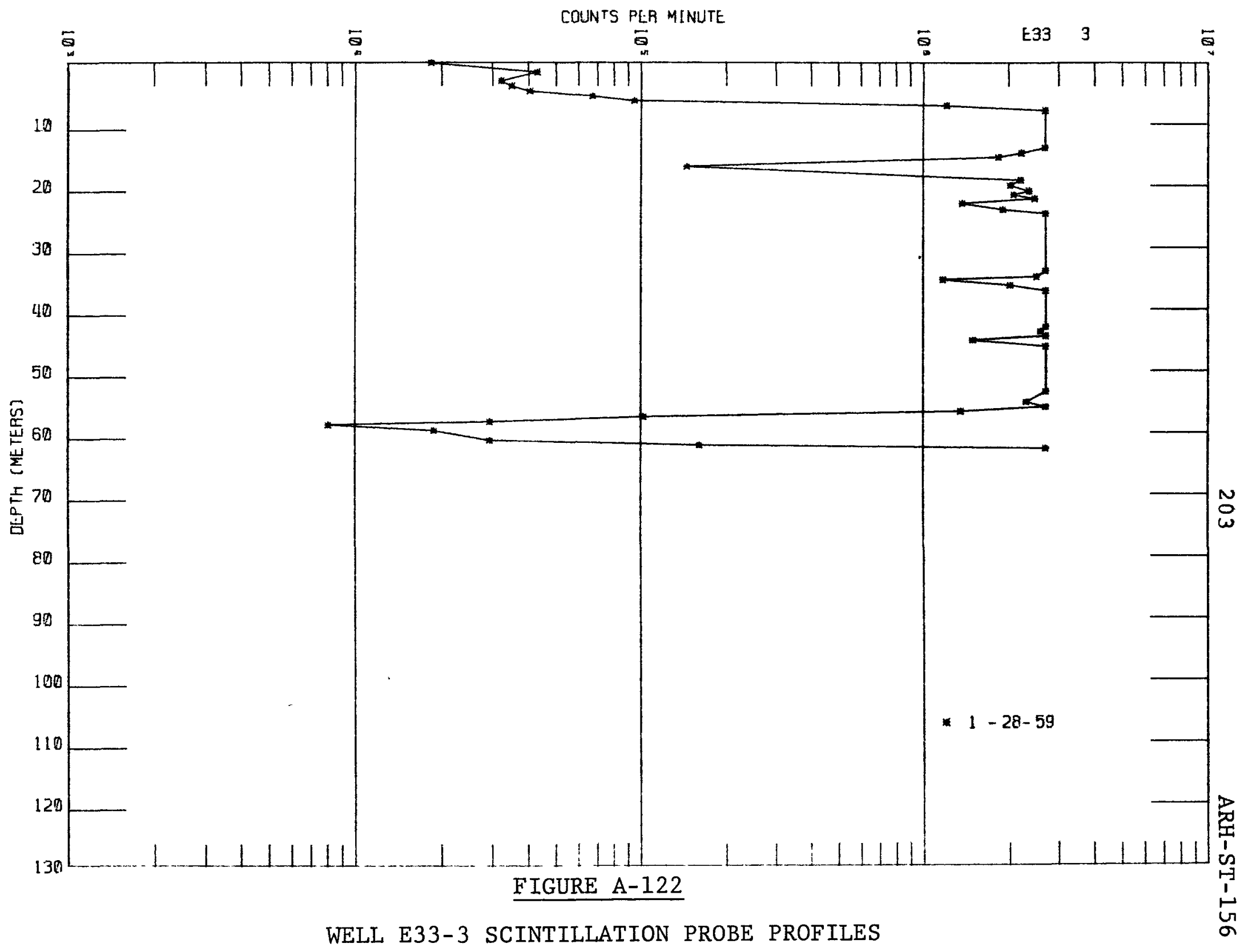




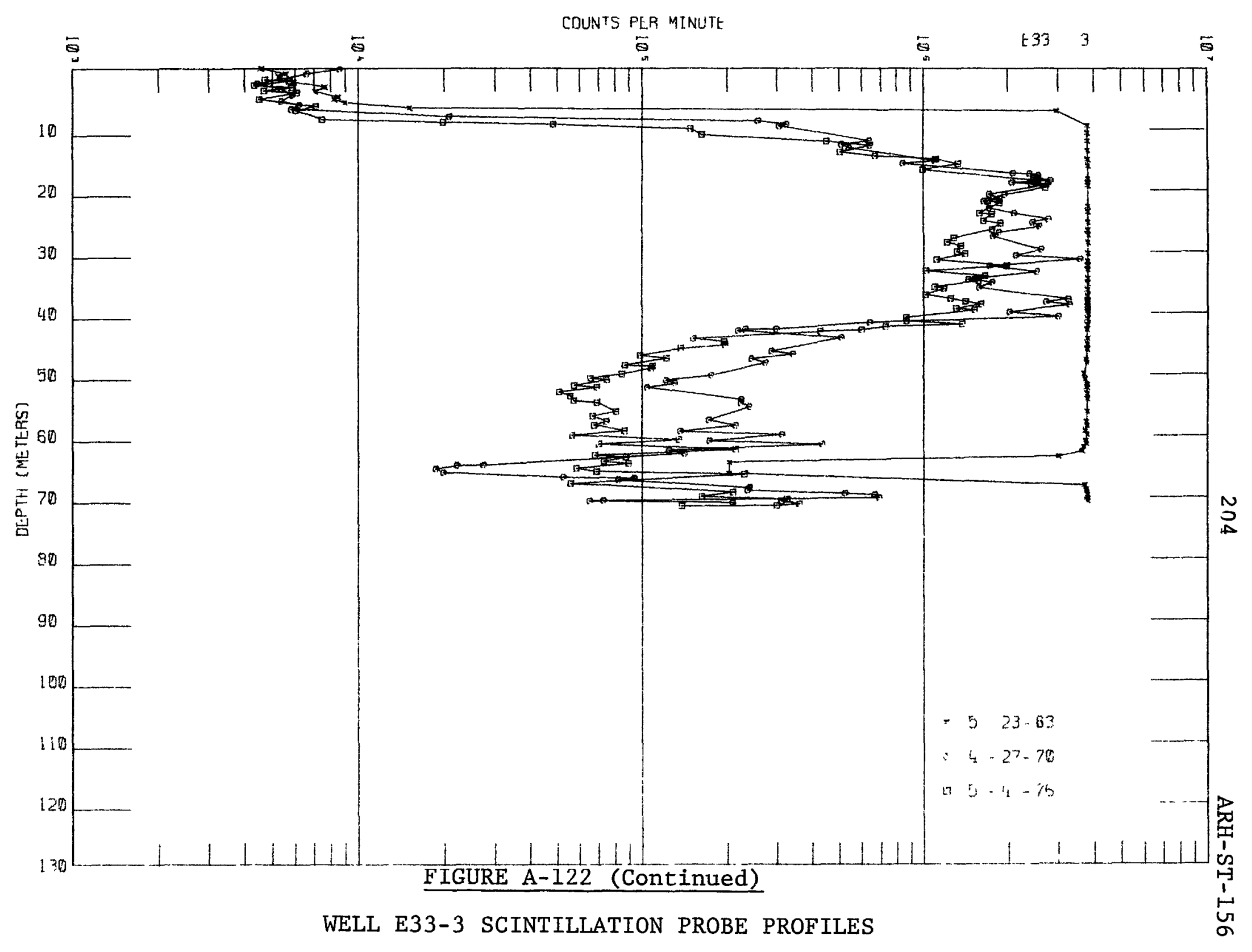




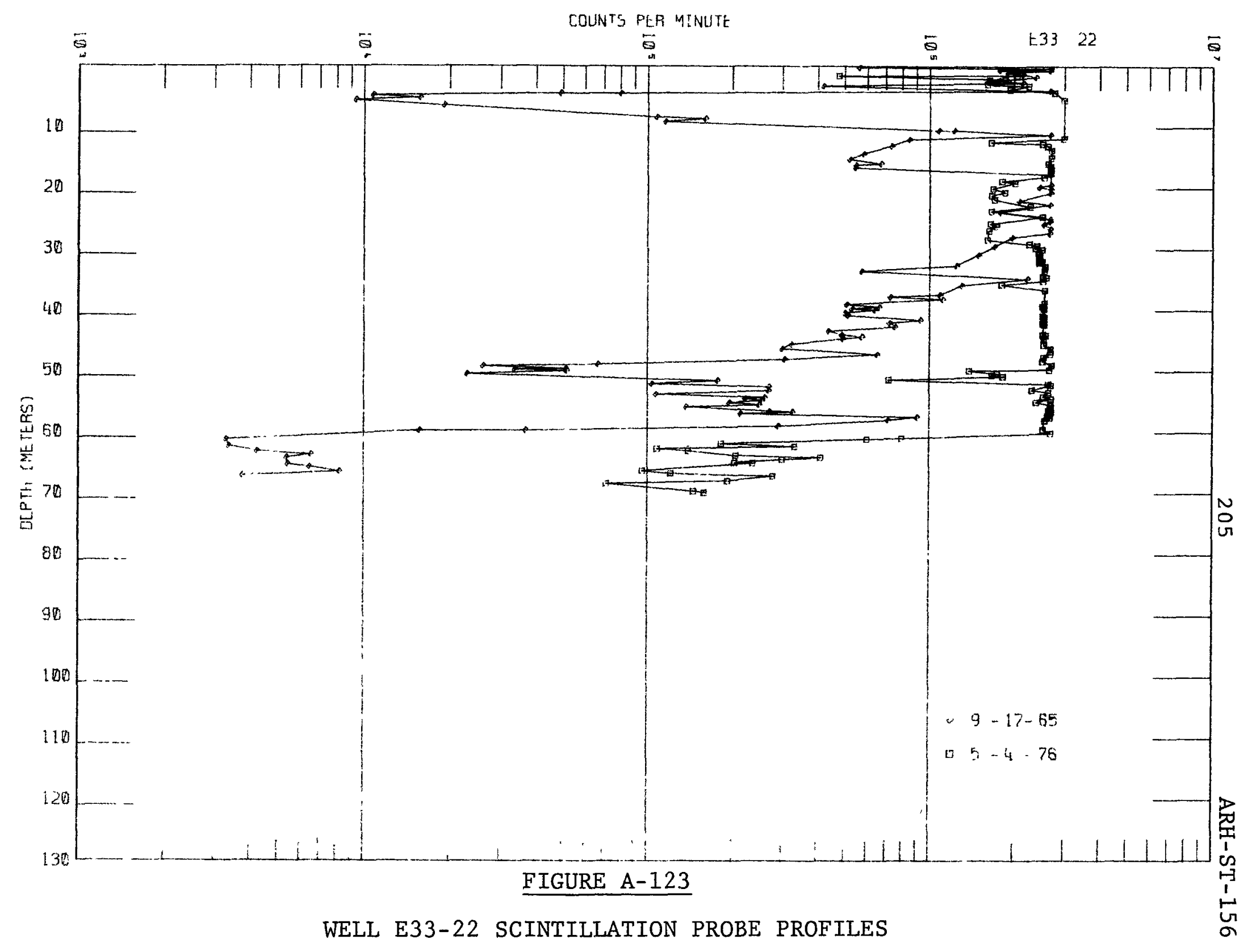


Description of Waste: Scavenged waste from uranium recovery (TBP solvent extraction) process in 221-U.

Service Date: 1955

Waste Volume: $6.70 \times 10^{6}$ liters

Waste Inventory:

\begin{tabular}{ccc} 
& Total & Decayed thru June 1976 \\
\cline { 2 - 3 } $\mathrm{Pu}, \mathrm{g}$ & $2.00 \times 10^{1}$ & $2.00 \times 10^{7}$ \\
${ }^{\text {Beta }, \mathrm{Ci}}$ & $1.20 \times 10^{5}$ & $2.06 \times 10^{3}$ \\
${ }^{90} \mathrm{Sr}, \mathrm{Ci}$ & $1.50 \times 10^{3}$ & $8.95 \times 10^{2}$ \\
${ }^{106} \mathrm{Ru}, \mathrm{Ci}$ & $2.80 \times 10^{4}$ & $1.44 \times 10^{-2}$ \\
${ }^{137} \mathrm{Cs}, \mathrm{Ci}$ & $2.00 \times 10^{2}$ & $1.23 \times 10^{2}$ \\
${ }^{60} \mathrm{Co}, \mathrm{Ci}$ & $5.00 \times 10^{0}$ & $3.14 \times 10^{-1}$ \\
$\mathrm{U}, \mathrm{kg}$ & $1.91 \times 10^{2}$ & $1.91 \times 10^{2}$
\end{tabular}

Evaluation of Scintillation Probe Profiles:

Wells E33-4 and E33-23 monitor the 216-B-46 crib (figures A-1 and A-119). In 1976, 21 years after waste disposal to the crib was terminated, radioactive contaminants are detected from 2.1 meters below the ground surface to the water table (figures $A-124$ and $A-125$ ). The radiation intensity in the zone of contamination is slowly decreasing indicating the presence of long-lived radionuclides throughout the contaminated sediment column.

On the basis of the scintillation probe profiles no measurable movement beneath the $216-\mathrm{B}-46 \mathrm{crib}$ is detected. These data indicate breakthrough to the groundwater could have occurred at this site. 
C

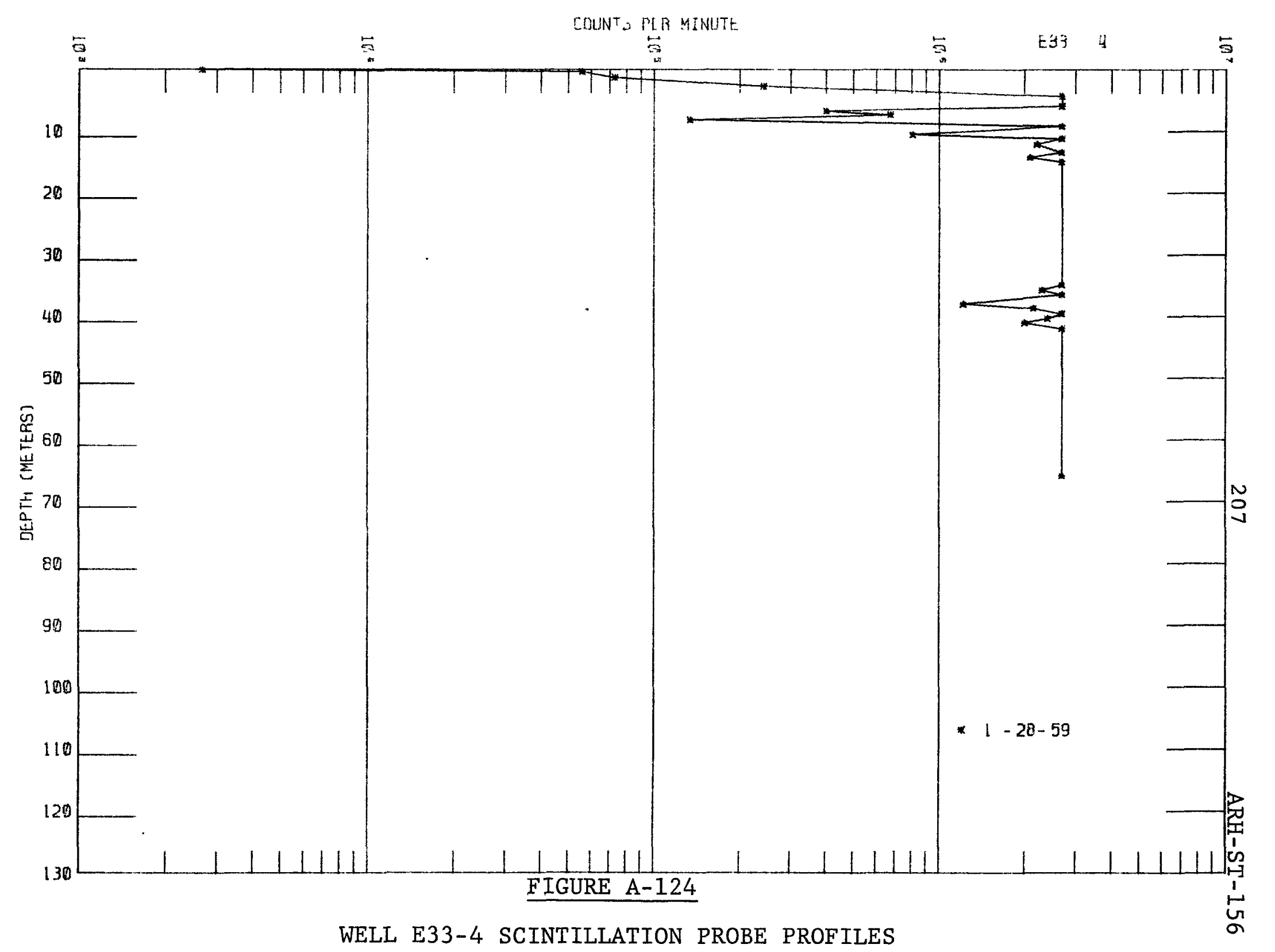




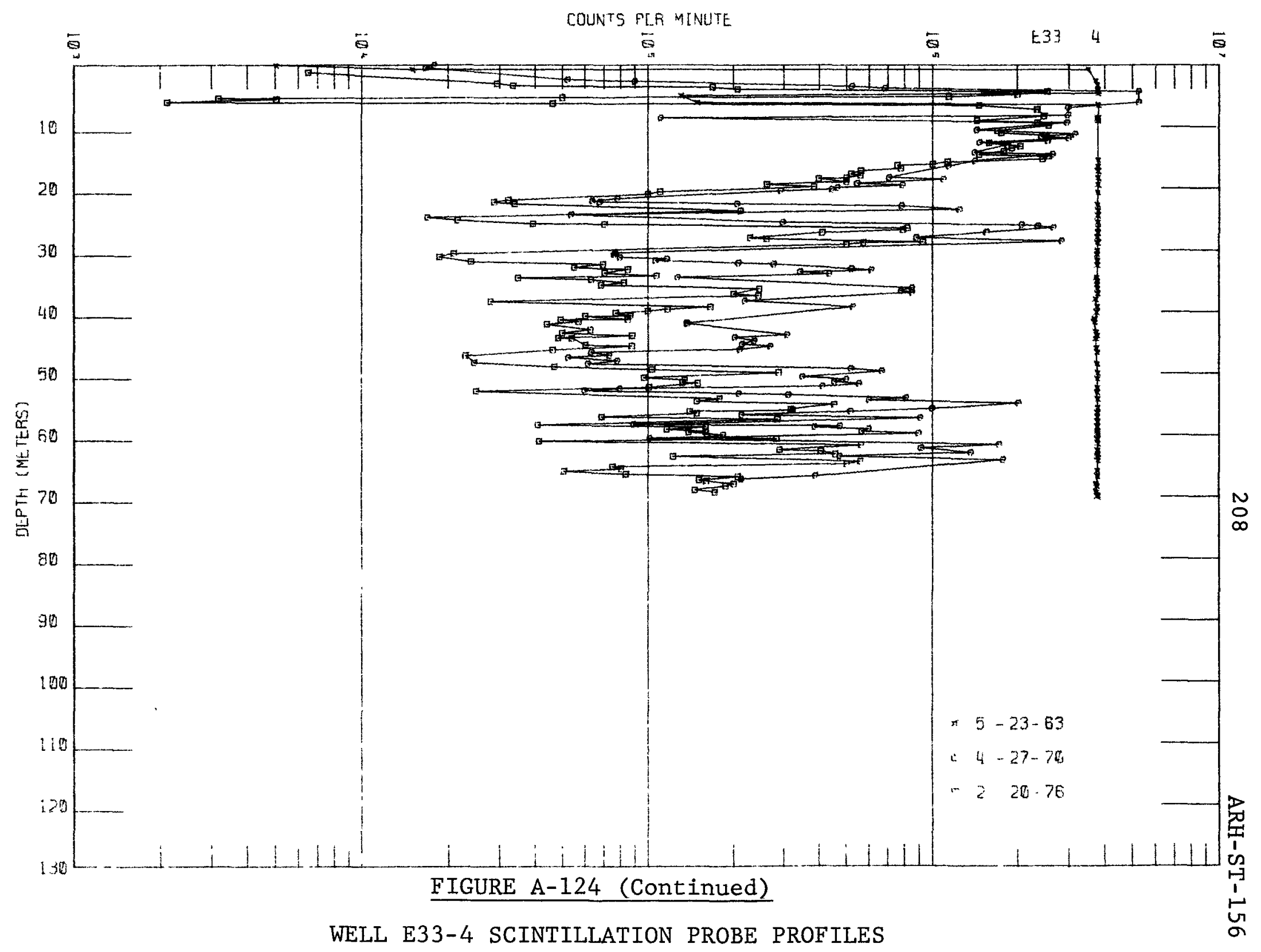




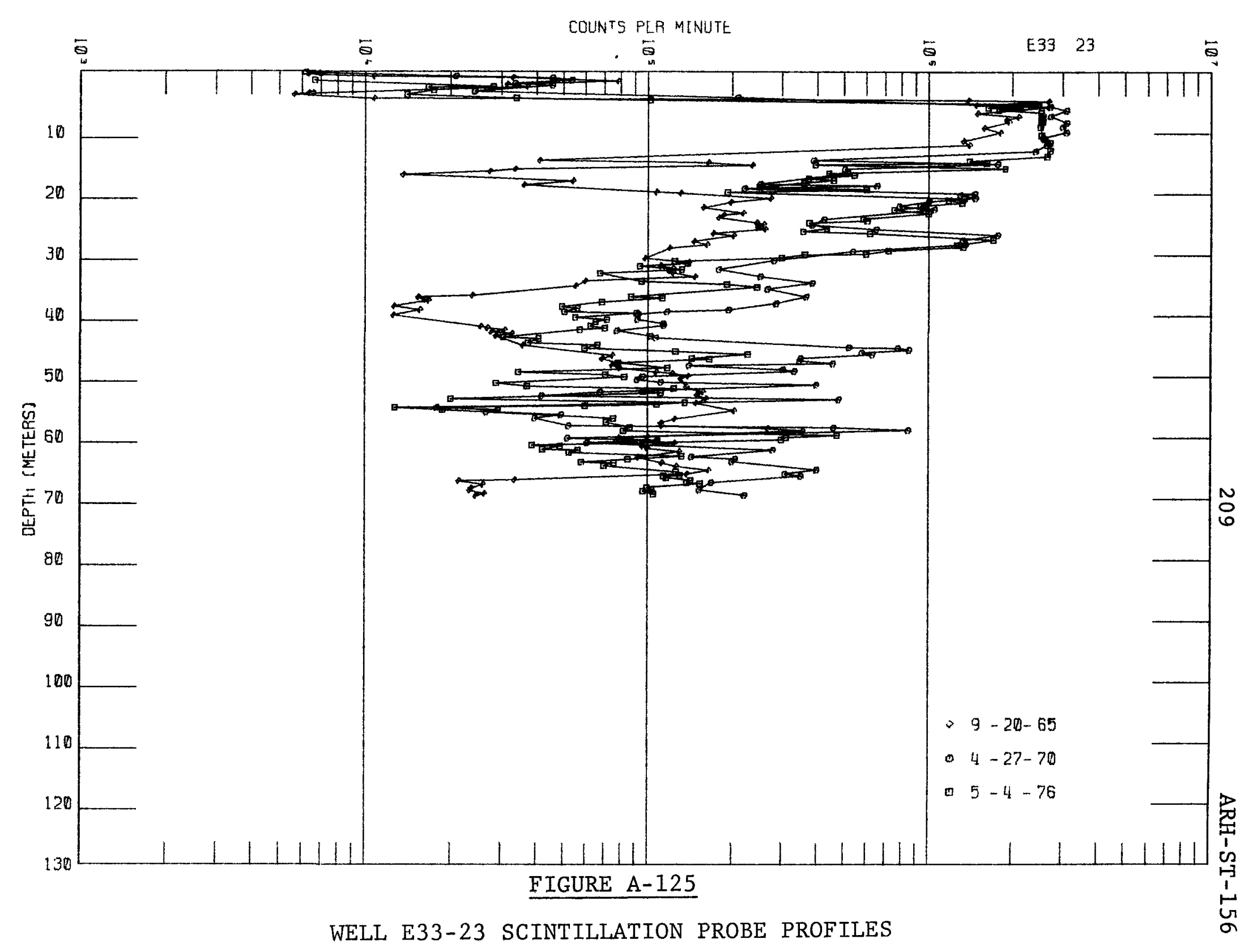




\section{6-B-47 Crib}

Description of Waste: Scavenged waste from uranium recovery (TBP soivent extraction) process in 221-U.

Service Date: 1955

Waste Volume: $3.71 \times 10^{6}$ 1iters

Waste Inventory:

\begin{tabular}{rcc} 
& Total & Decayed thru June 1976 \\
\cline { 2 - 3 } $\mathrm{Pu}, \mathrm{g}$ & $5.00 \times 10^{0}$ & $5.00 \times 10^{0}$ \\
${ }^{\text {Beta, } \mathrm{Ci}}$ & $4.50 \times 10^{4}$ & $9.21 \times 10^{2}$ \\
${ }^{90} \mathrm{Sr}, \mathrm{Ci}$ & $6.20 \times 10^{2}$ & $3.70 \times 10^{2}$ \\
${ }^{106} \mathrm{Ru}, \mathrm{Ci}$ & $1.90 \times 10^{4}$ & $9.74 \times 10^{-2}$ \\
${ }^{137} \mathrm{Cs}, \mathrm{Ci}$ & $1.50 \times 10^{2}$ & $9.25 \times 10^{7}$ \\
${ }^{60} \mathrm{Co}, \mathrm{Ci}$ & $1.00 \times 10^{0}$ & $6.28 \times 10^{-2}$ \\
U, kg & $6.80 \times 10^{0}$ & $6.80 \times 10^{0}$
\end{tabular}

Evaluation of Scintillation Probe Profiles:

We11 E33-5 monitors the 216-B-47 crib (figures $A-1$ and A-119). In 1976, 21 years after waste disposal to the crib was terminated, radioactive contaminants are detected between the 12.2 and 37.2 meter depths below the ground surface (figure A-126). The radiation intensity in the zone of contamination is slowly decreasing indicating the presence of longlived radionuclides throughout the contaminated sediments column.

On the basis of the scintillation probe profiles no measurable movement of radionuclides beneath the 216-B-47 crib is detected. These data indicate breakthrough to the groundwater has not occurred at this site. 
C 1

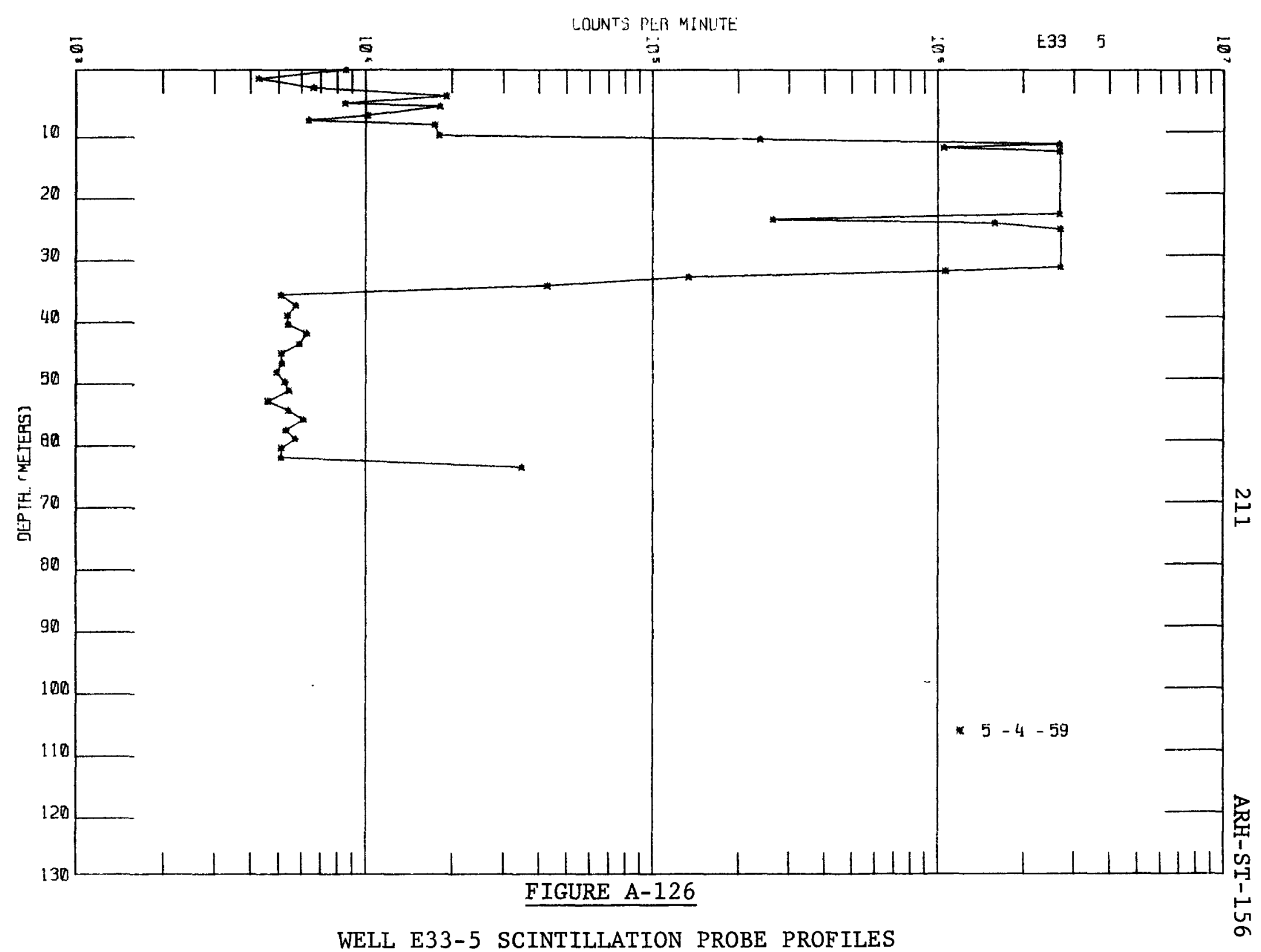




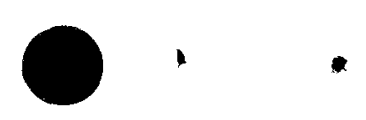

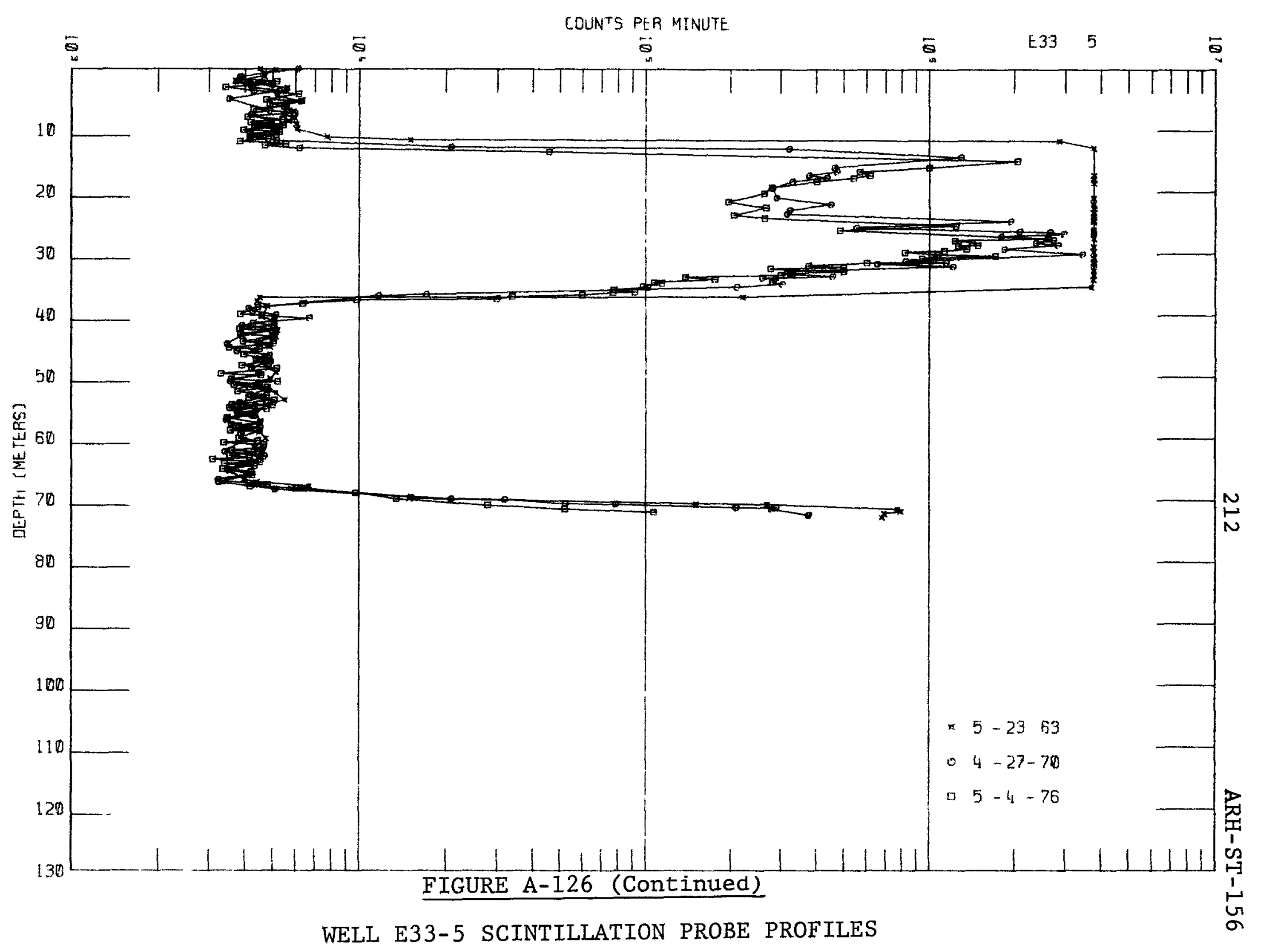


Description of Waste: Scavenged waste from uranium recovery (TBP solvent extraction) process in 221-U.

Service Date: 1955

Waste Volume: $4.09 \times 10^{6}$ 1iters

Waste Inventory:

\begin{tabular}{ccc} 
& Total & Decayed thru June 1976 \\
\cline { 2 - 3 } $\mathrm{Pu}, \mathrm{g}$ & $5.00 \times 10^{0}$ & $5.00 \times 10^{0}$ \\
${ }^{\text {Beta }, \mathrm{Ci}}$ & $6.10 \times 10^{4}$ & $2.11 \times 10^{3}$ \\
${ }^{90} \mathrm{Sr}, \mathrm{Ci}$ & $1.30 \times 10^{3}$ & $7.76 \times 10^{2}$ \\
${ }^{106} \mathrm{Ru}, \mathrm{Ct}$ & $6.80 \times 10^{3}$ & $3.49 \times 10^{-3}$ \\
${ }^{137} \mathrm{Cs}, \mathrm{Ct}$ & $4.50 \times 10^{2}$ & $2.78 \times 10^{2}$ \\
${ }^{60} \mathrm{Co}, \mathrm{Ci}$ & $1.00 \times 10^{0}$ & $6.28 \times 10^{-2}$ \\
$\mathrm{U}, \mathrm{kg}$ & $2.27 \times 10^{0}$ & $2.27 \times 10^{0}$
\end{tabular}

Evaluation of Scintillation Probe Profiles:

We11 E33-6 monitors the 216-B-48 crib (figures A-1 and A-119). In 1976, 21 years after waste disposal to the crib was terminated, radioactive contaminants are detected between the 3.4 and 46.4 meter depths below the ground surface (figure A-127). The radiation intensity in the zone of contamination is slowly decreasing indicating the presence of long-lived radionuclides.

On the basis of the scintillation probe profiles no measurable movement of radionuclides beneath the 216-B-48 crib is detected. These data indicate breakthrough to the groundwater could have occurred at this site. 
C

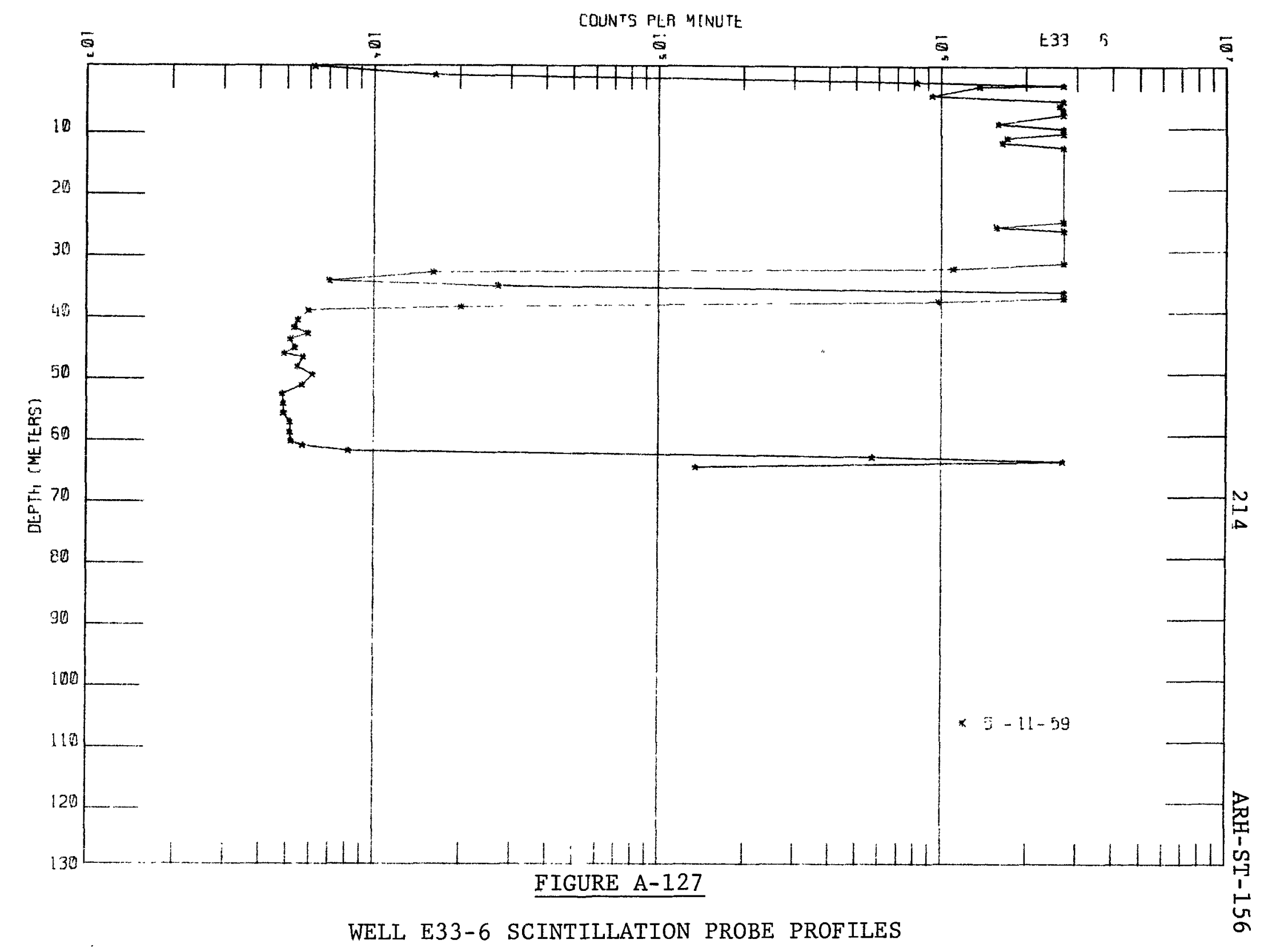




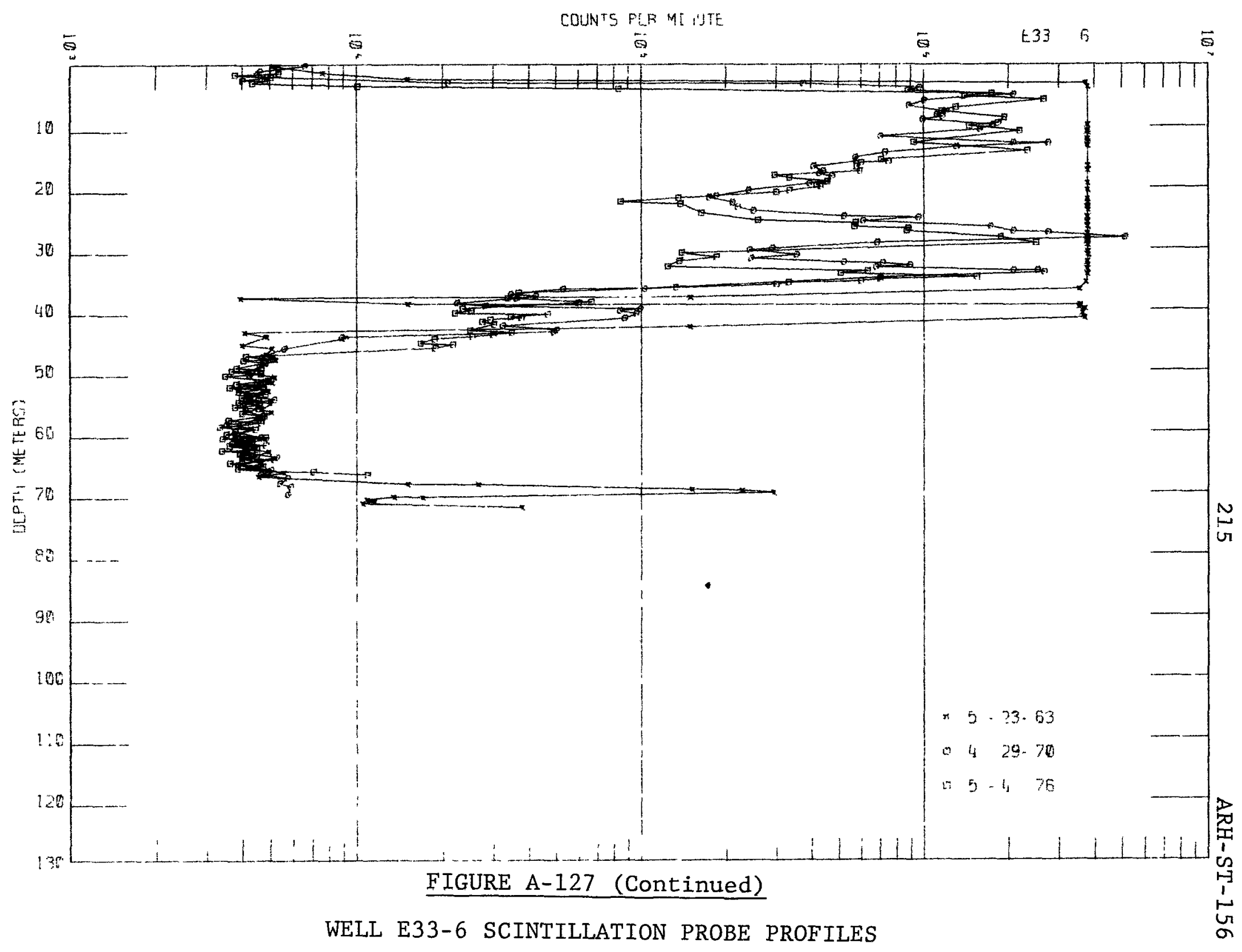




\section{6-B-50 Crib}

Description of Waste: Waste storage tank condensate from the ITS \#1 unit in the 241-BY Tank Farm.

Service Dates: 1965 to 1974

Waste Volume: $5.48 \times 10^{7}$ iiters

Waste Inventory:

\begin{tabular}{ccc} 
& Total & Decayed thru June 1976 \\
\cline { 2 - 3 } $\mathrm{Pu}, \mathrm{g}$ & $<2.39 \times 10^{-1}$ & $<2.39 \times 10^{-1}$ \\
${ }^{\text {Beta }, \mathrm{Ci}}$ & $2.41 \times 10^{2}$ & $1.47 \times 10^{2}$ \\
${ }^{90} \mathrm{Sr}, \mathrm{Ci}$ & $<6.00 \times 10^{0}$ & $<4.81 \times 10^{0}$ \\
${ }^{106} \mathrm{Ru}, \mathrm{Ci}$ & $1.11 \times 10^{7}$ & $2.01 \times 10^{-2}$ \\
${ }^{137} \mathrm{Cs}, \mathrm{Ci}$ & $8.78 \times 10^{1}$ & $7.10 \times 10^{1}$ \\
${ }^{60} \mathrm{Co}, \mathrm{Ci}$ & $<3.31 \times 10^{-1}$ & $<9.91 \times 10^{-2}$ \\
$\mathrm{U}, \mathrm{kg}$ & $<2.85 \times 10^{-1}$ & $<2.85 \times 10^{-1}$
\end{tabular}

\section{Evaluation of Scintillation Probe Profiles:}

We17 E33-7 monitors the 216-B-50 crib (figure A-1 and A-119). Radioactive contaminants detected in the well prior to use of the crib in 1965 have migrated laterally from waste discharge from the 216-B-45, $216-B-46$ and $216-B-49$ cribs (figure $A-128$ ). By 1976 radioactive contaminants in Well E33-7 are detected from 3.0 meters below the ground surface to the water table.

On the basis of the scintillation probe profiles soil drainage has occurred beneath the $216-B-50$ crib during waste discharges to the ground at this site. These data indicate breakthrough to the groundwater could have occurred at this site. 
C

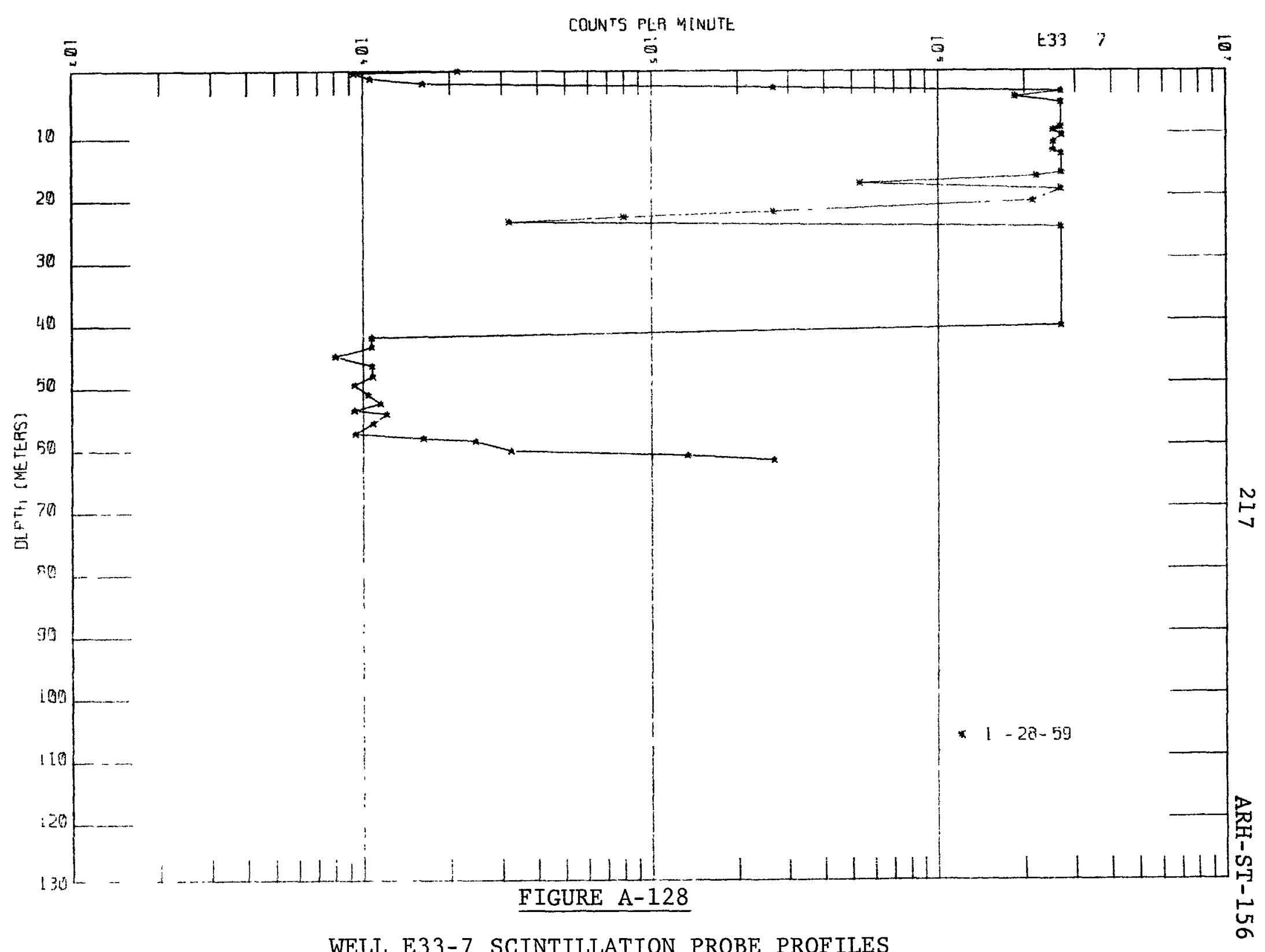




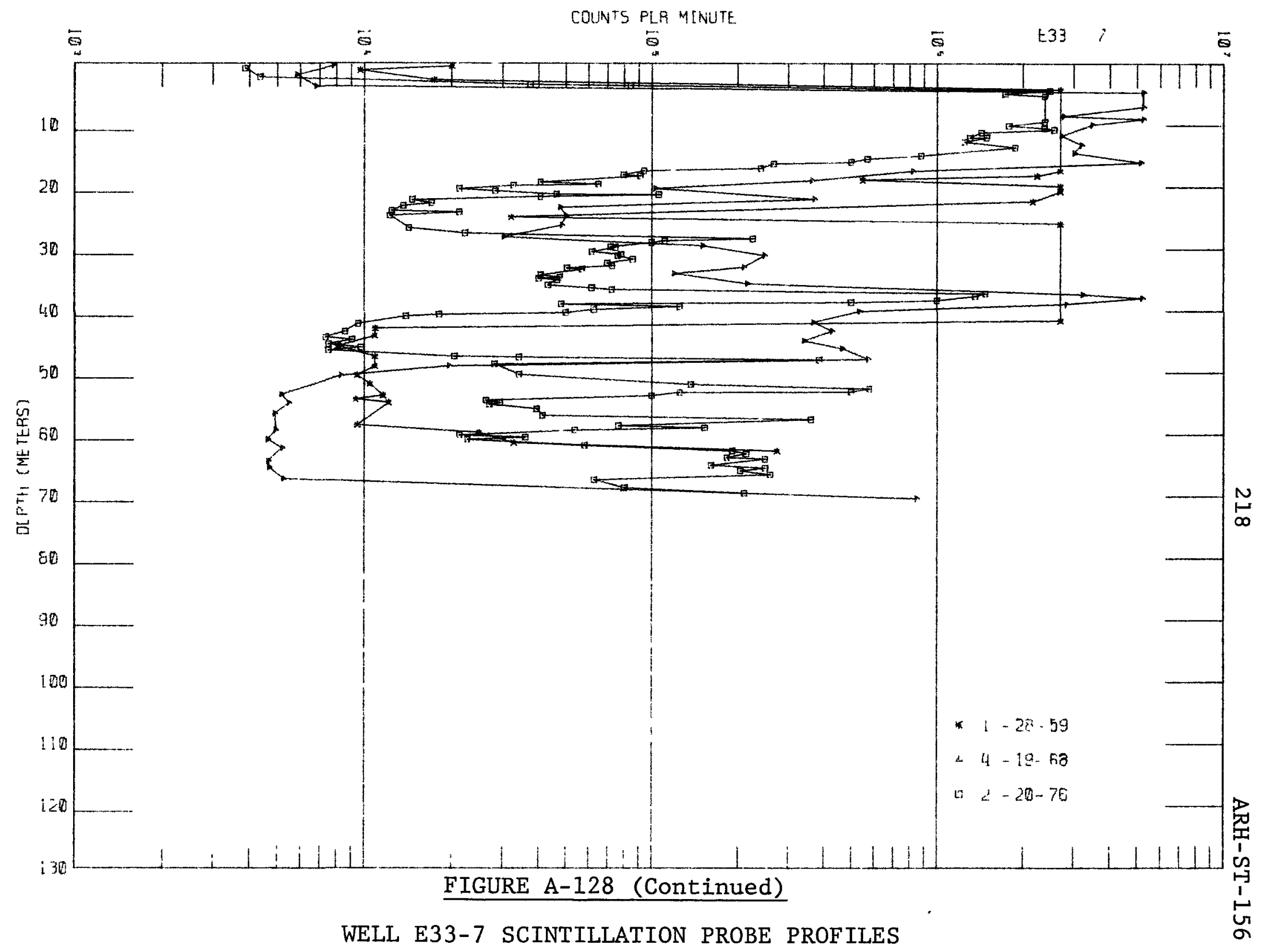




\section{6-B-51 French Drain}

Description of Waste: Received flush drainage from $B C$ crib pipeline.

Service Dates: 1956 to 1958

Waste Volume: Unknown

Waste Inventory: Estimated $<10 \mathrm{Ci}$ Beta

Evaluation of Scintillation Probe Profiles:

Wells E33-11 and E33-14 are groundwater monitoring structures located 42.1 meters to the northeast and 126.8 meters to the southeast of the 216-B-51 french drain. (figure A-1). Background activity is detected in both wells (figures A-129 and A-130). On the basis of scintillation probe profiles and the estimated waste inventory, breakthrough to groundwater has not occurred at this site. 
C

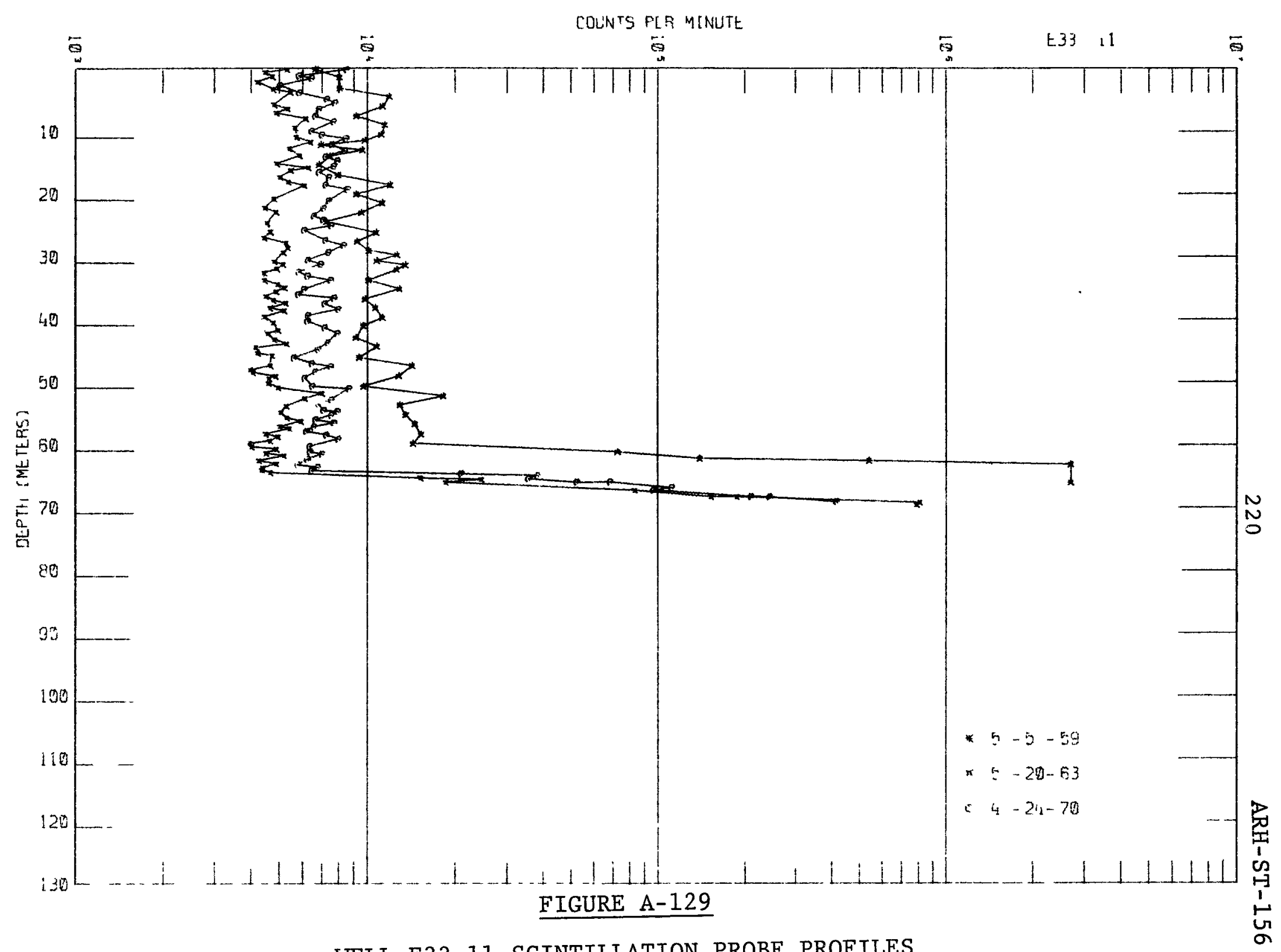




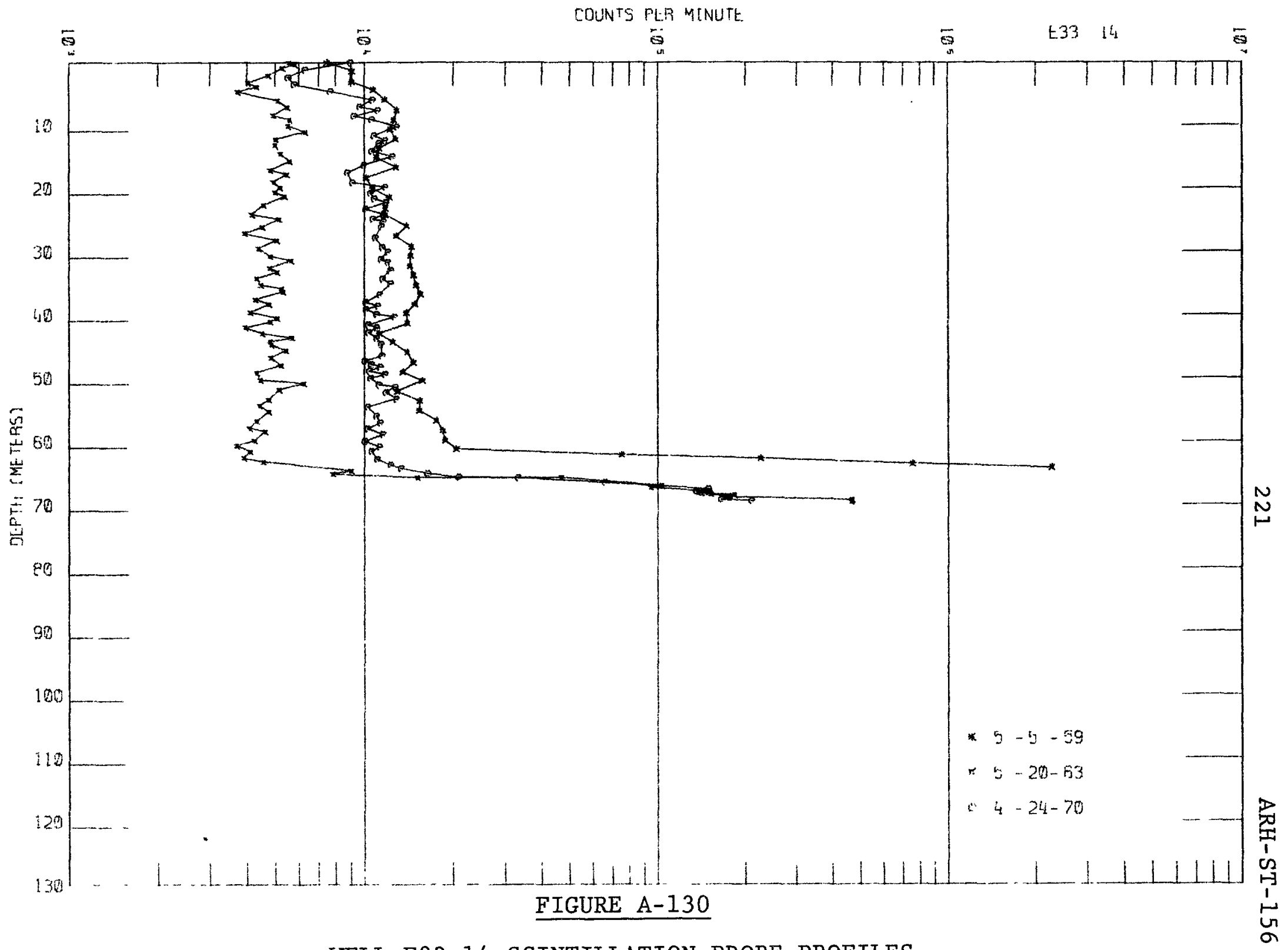

WELL E33-14 SCINTILLATION PROBE PROFILES 


\section{6-B-55 Crib}

Description of Waste: Steam condensate from 221-B.

Service Dates: 1967 to present

Waste Volume: $7.75 \times 10^{8}$

Waste Inventory:

\begin{tabular}{ccc} 
& Total & Decay Thru June 1976 \\
\cline { 2 - 3 } $\mathrm{Pu}, \mathrm{g}$ & $<4.65 \times 10^{-1}$ & $<4.65 \times 10^{-1}$ \\
Beta, Ci & $1.50 \times 10^{2}$ & $5.79 \times 10^{7}$ \\
$90_{\mathrm{Sr}}, \mathrm{Ci}$ & $<1.11 \times 10^{1}$ & $<9.96 \times 10^{0}$ \\
$106 \mathrm{Ru}, \mathrm{Ci}$ & $<1.72 \times 10^{0}$ & $<1.75 \times 10^{-1}$ \\
${ }^{137} \mathrm{Cs}, \mathrm{Ci}$ & $2.11 \times 10^{1}$ & $1.85 \times 10^{1}$ \\
${ }^{60} \mathrm{Co}, \mathrm{Ci}$ & $<3.82 \times 10^{-1}$ & $<1.69 \times 10^{-1}$ \\
U, k0 & $<5.40 \times 10^{7}$ & $<5.40 \times 10^{0}$
\end{tabular}

Evaluation of Scintillation Probe Profiles:

We11 E28-12 monitors the active 216-B-55 steam condensate crib (figures $A-1$ and $A-131$ ). Only background radioactivity is detected in this well (figure A-132). These data indicate breakthrough to the groundwater has not occurred at this site. 
C -

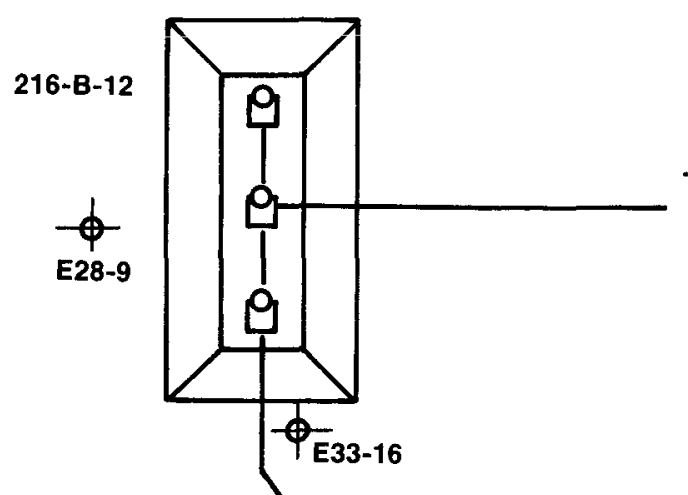

FIGURE A-131 
$\longrightarrow+x$

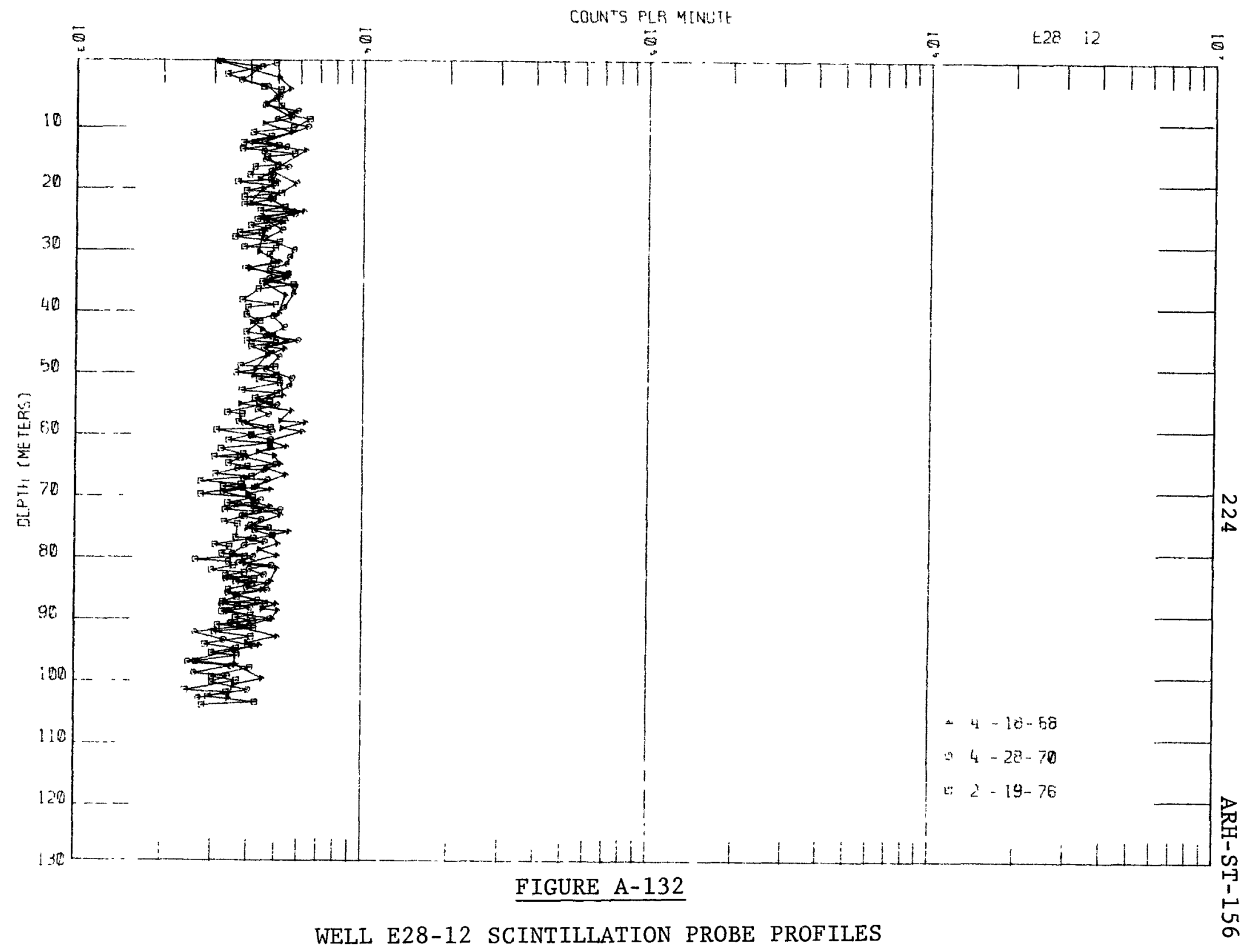




\section{6-B-56 Specific Retention Crib}

Description of Waste: To receive organic waste from 221-B.

Service Dates: Never used

Waste Volume: None

Waste Inventory: Not applicable

Evaluation of Scintillation Probe Profiles:

Well E28-14 monitors the 216-B-56 specific retention crib (figures $A-1$ and A-133). Since the 216-B-56 crib has never been used, only background activity is detected (figure A-134). 


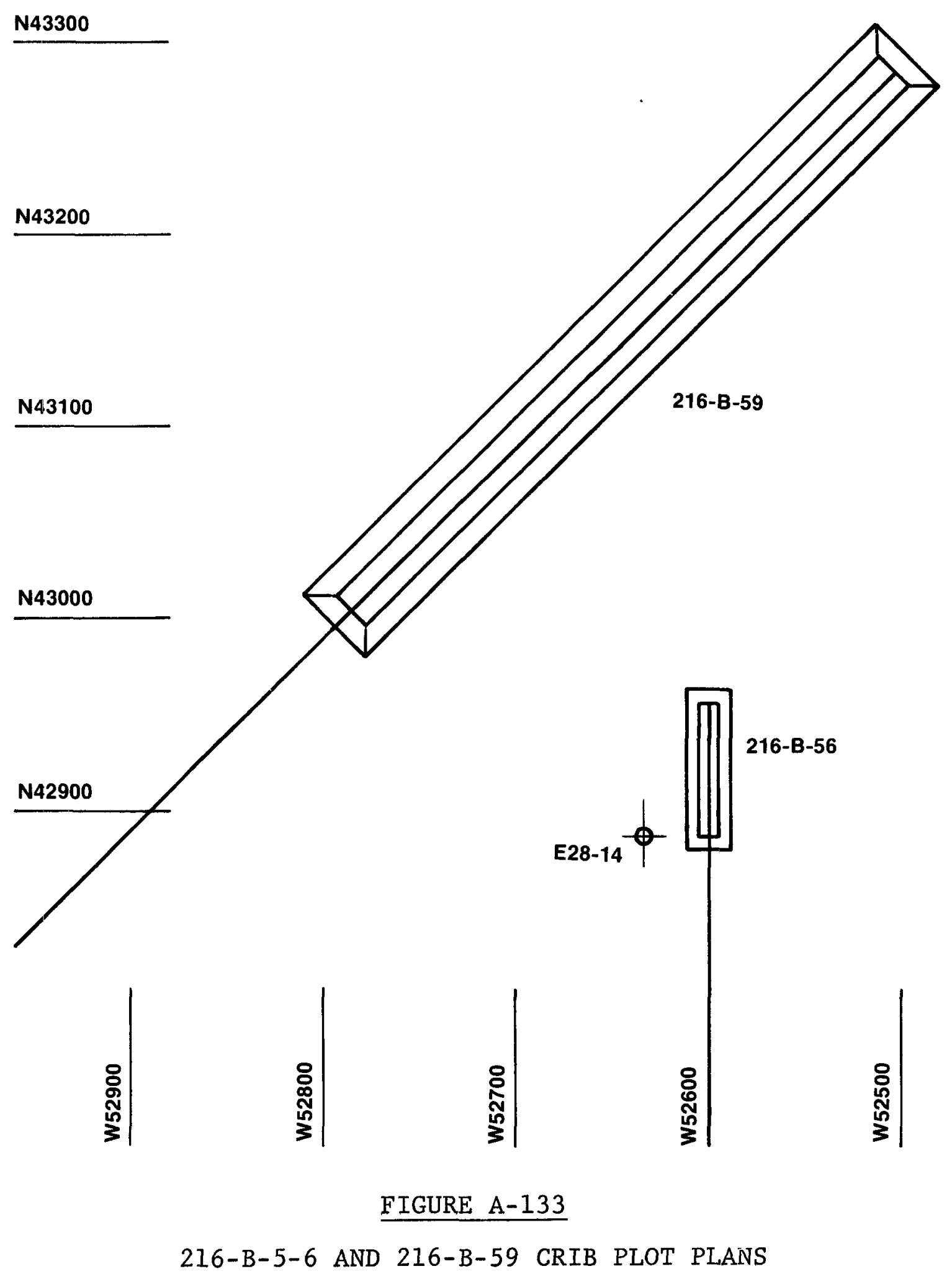


C

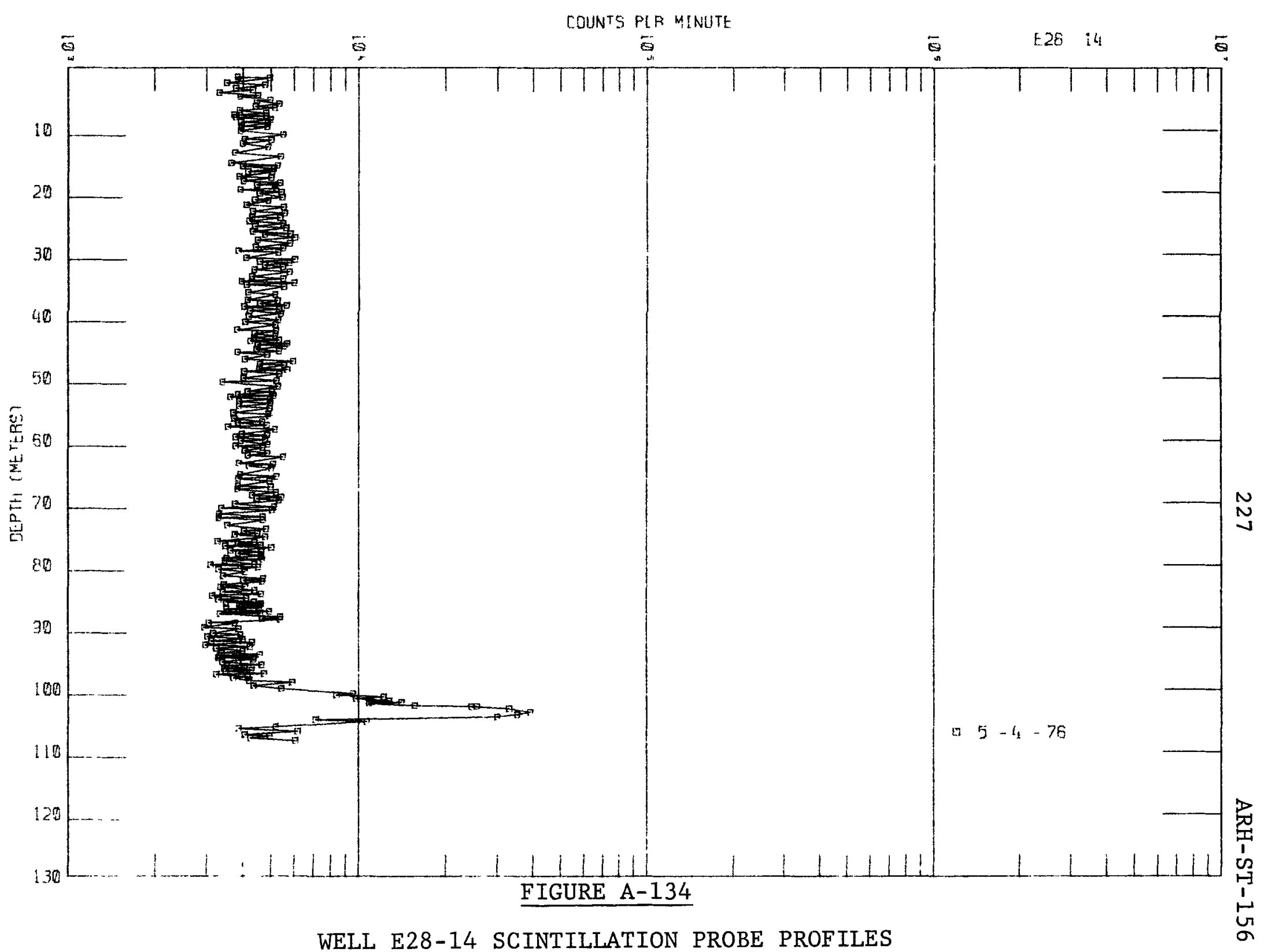


Description of Waste: Waste storage tank condensate from ITS "i2 unit in the 241-BY Tank Farm

Service Dates: 1968 to 1973

Waste Volume: $8.44 \times 10^{7}$ 1iters

Waste Inventory:

\begin{tabular}{|c|c|c|}
\hline & Total & Decay Thru June 1976 \\
\hline $\mathrm{Pu}, \mathrm{g}$ & $<1.87 \times 10^{-1}$ & $<1.87 \times 10^{-1}$ \\
\hline Beta, Ci & $8.38 \times 10^{2}$ & $6.08 \times 10^{2}$ \\
\hline${ }^{90} \mathrm{Sr}, \mathrm{Ci}$ & $3.15 \times 10^{0}$ & $2.6 \times 10^{0}$ \\
\hline${ }^{106} \mathrm{Ru}, \mathrm{Ci}$ & $8.71 \times 10^{0}$ & $<8.87 \times 10^{-2}$ \\
\hline${ }^{137} \mathrm{Cs}, \mathrm{Ci}$ & $3.71 \times 10^{2}$ & $3.13 \times 10^{2}$ \\
\hline${ }^{60} \mathrm{Co}, \mathrm{Ci}$ & $<1.36 \times 10^{-1}$ & $<5.13 \times 10^{-2}$ \\
\hline $\mathrm{U}, \mathrm{kg}$ & $<8.90 \times 10^{-1}$ & $<8.90 \times 10^{-1}$ \\
\hline
\end{tabular}

Evaluation of Scintillation Probe Data:

Wel1 E33-24 monitors the 216-B-57 tank farm condensate crib (figures $A-1$ and $A-135)$. Radioactive contaminants are detected from 7.6 to 19.8 meters below the ground surface (figure A-136). The radiation intensity has been increasing since the well was first logged 5 months after the crib was put into service. This increase is due to the continual discharge of radioactive effluent to the crib through 1973 .

The contaminants are high in the sediment column beneath the crib. Very little downward movement of radionuclides in the sediments has occurred since the initial zone of contamination was detected. These data indicate breakthrough to the groundwater has not occurred at this site. 


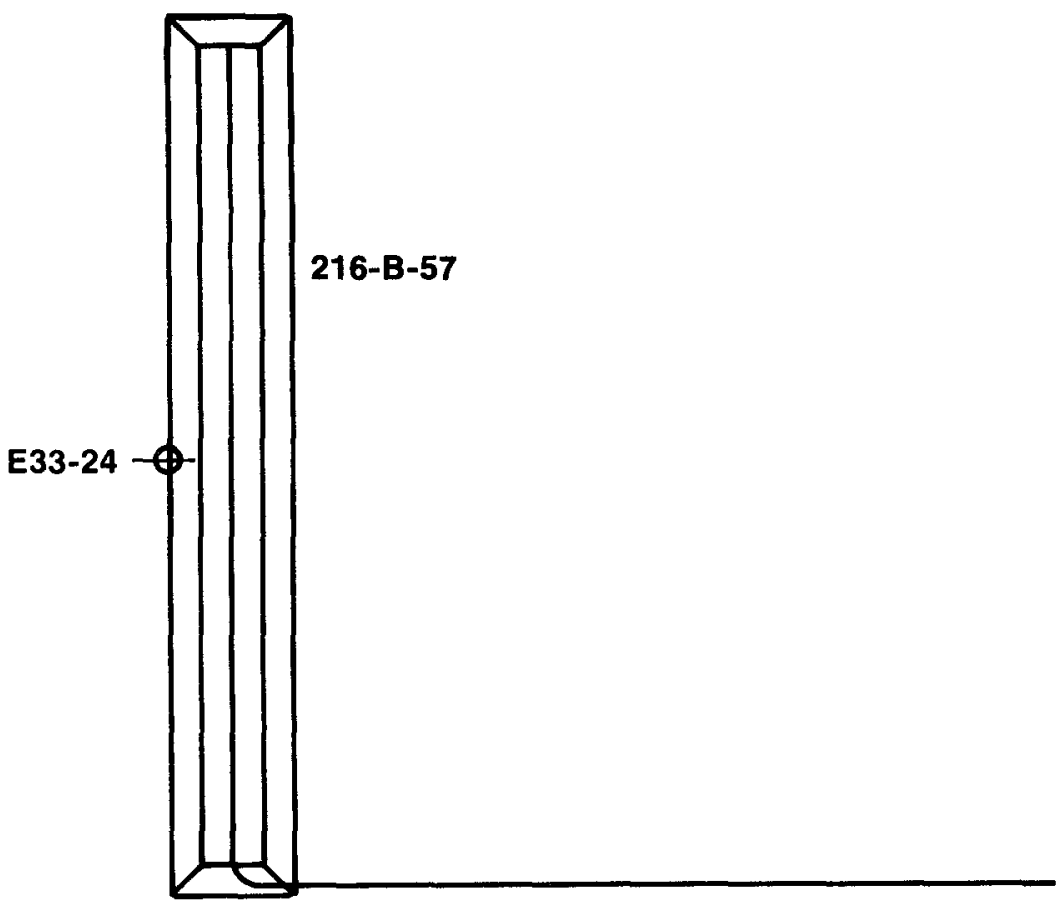


O.

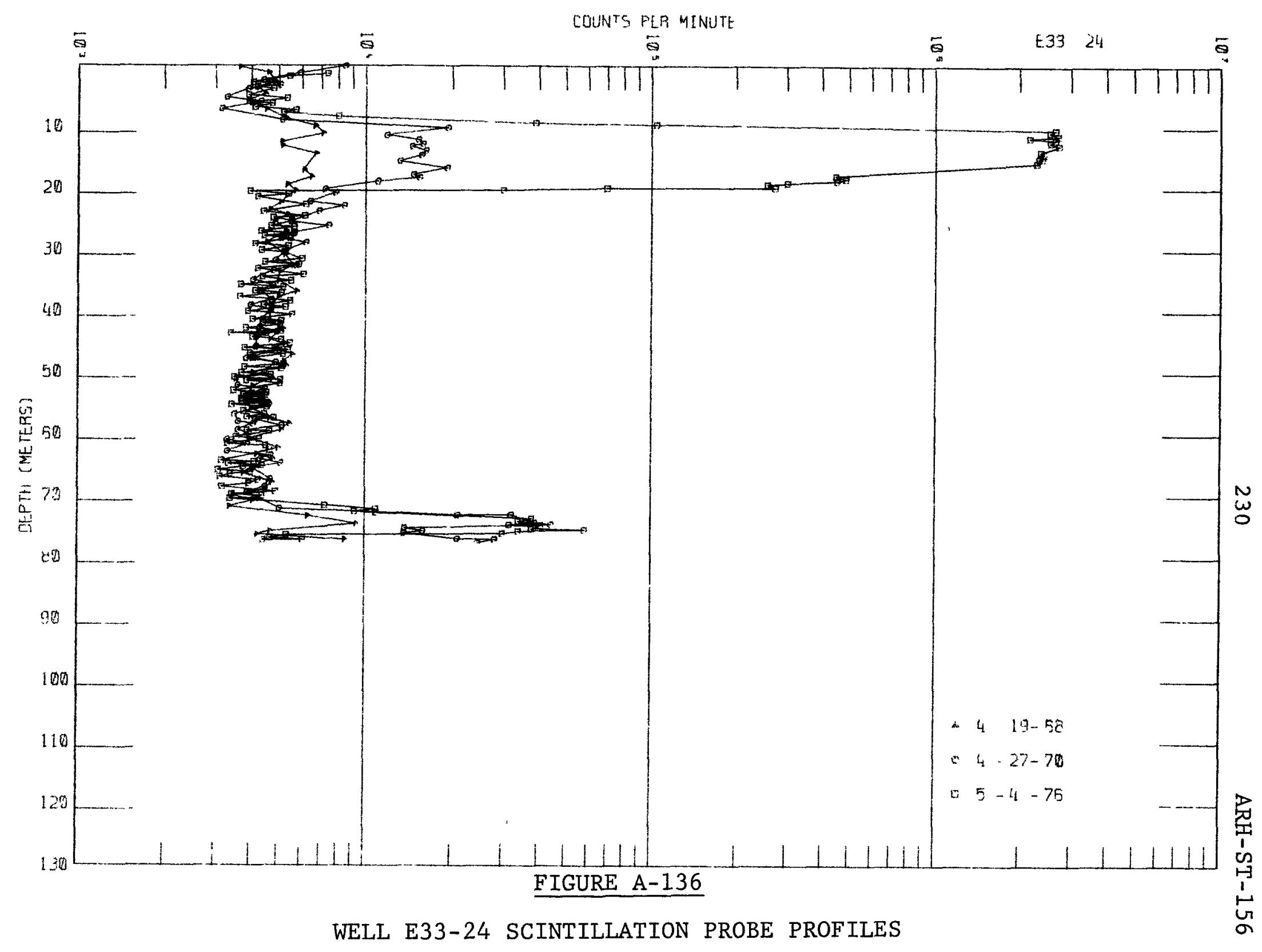




\section{6-B-61 Crib}

Description of Waste: To receive waste storage tank condensate from its \#1 Unit in the 241-BY Tank Farm.

Service Dates:' Never Used

Waste Volume: None

Waste Inventory: Not applicable

Evaluation of Scintillation Probe Profiles:

Wells E33-25 and E33-26 monitor the 216-B-61 tank farm condensate crib (figures $A-1$ and $A-137$ ). Low level radioactive contaminants are detected in the monitoring wells. The source of these contaminants is not known (Figures $A-138$ and A-139). 
216-B-61

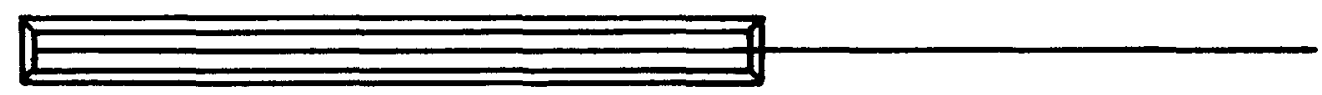

FIGURE A-137

216-B-61 CRIB PLOT PLAN 
C 6

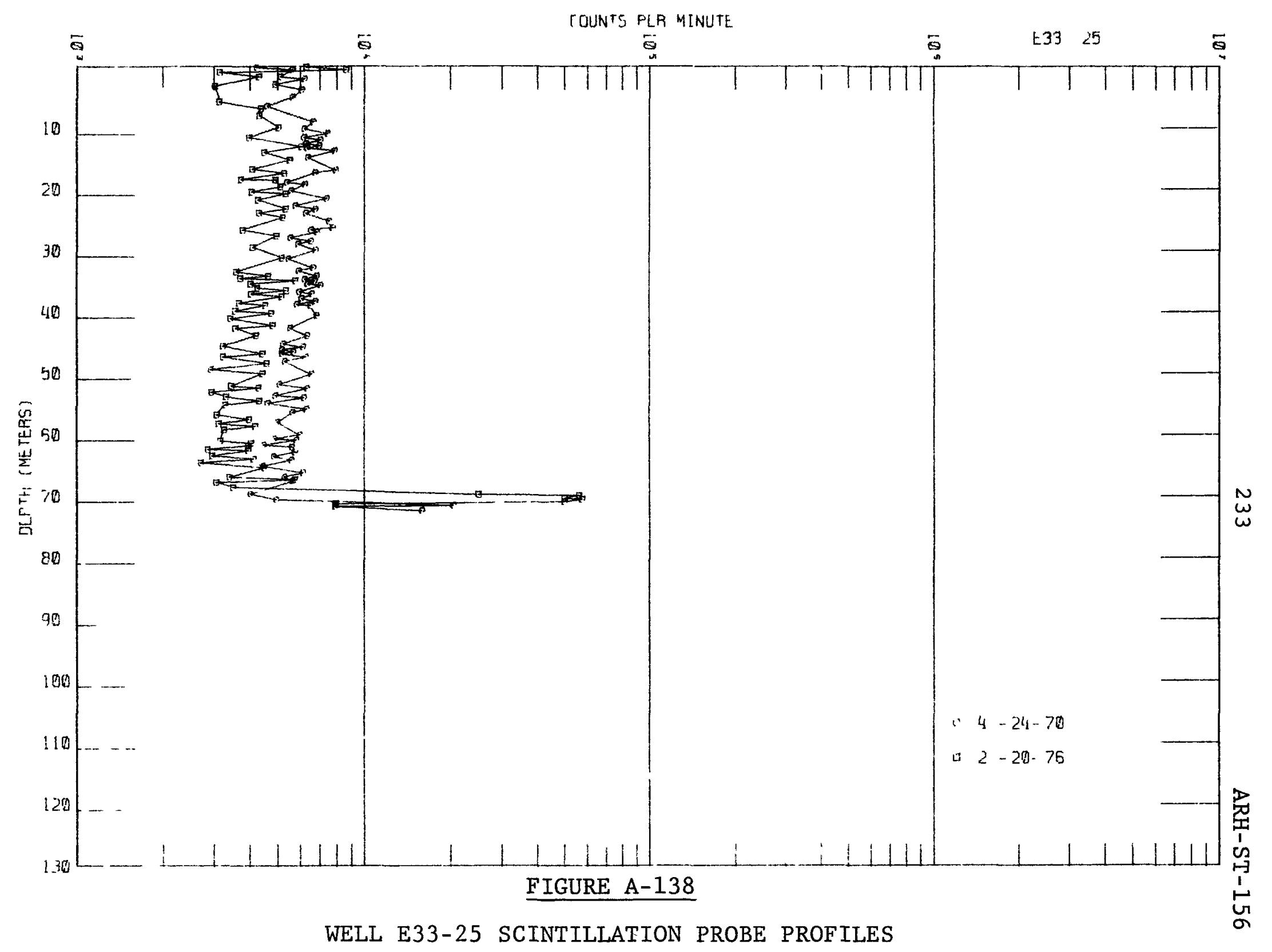




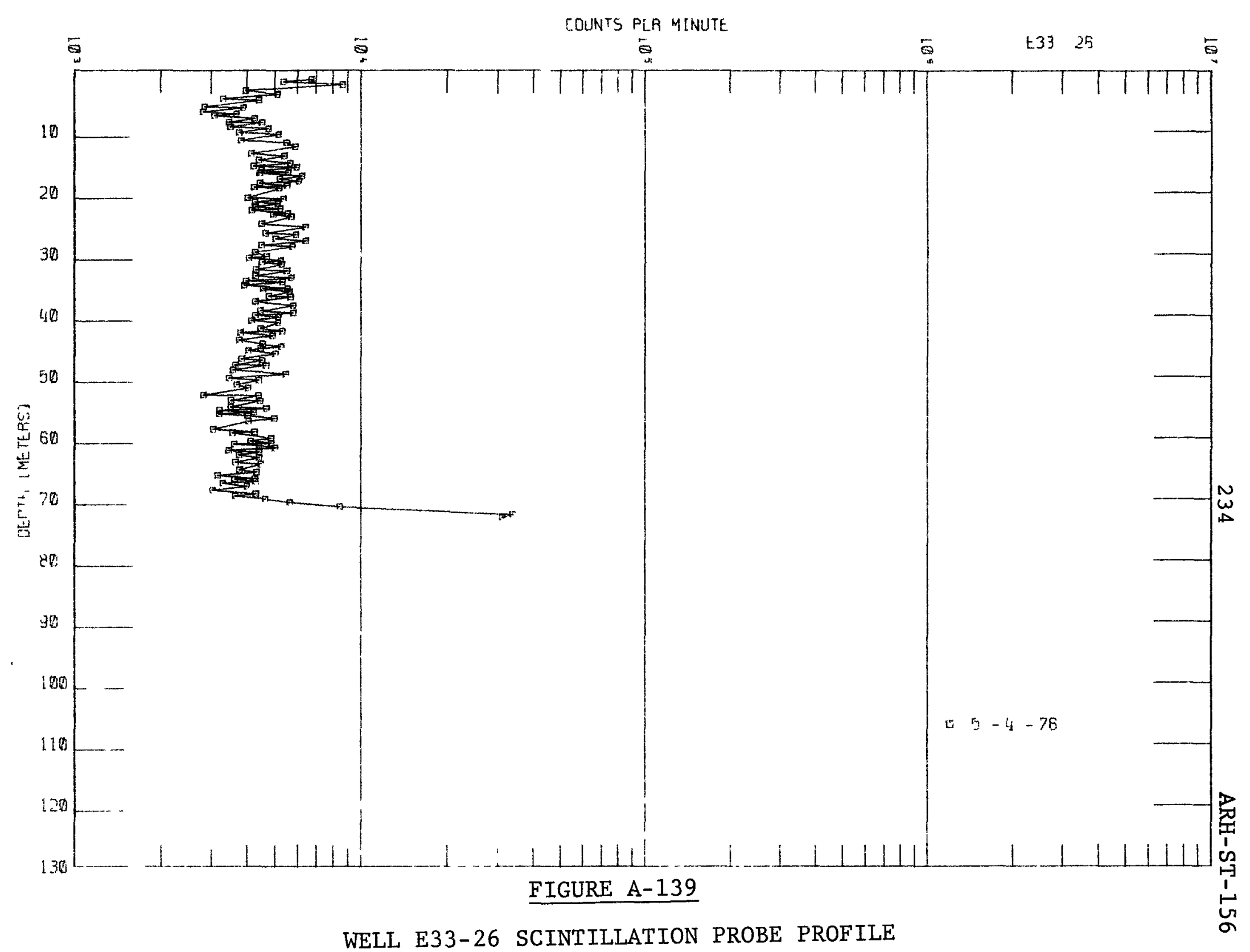




\section{6-B-62 Crib}

\section{Description of Waste: B Plant Process Condensate}

Service Dates: 1973 to present

Waste Volume: $8.06 \times 10^{7}$ liters

Waste Inventory:

\begin{tabular}{ccc} 
& Total & Decay Thru June 1976 \\
\cline { 2 - 3 } $\mathrm{Pu}, \mathrm{g}$ & $<2.14 \times 10^{-1}$ & $<2.14 \times 10^{-1}$ \\
$\mathrm{Beta}^{\mathrm{C}} \mathrm{Ci}$ & $8.52 \times 10^{1}$ & $5.52 \times 10^{1}$ \\
${ }^{90} \mathrm{Sr}, \mathrm{Ci}$ & $1.03 \times 10^{1}$ & $1.00 \times 10^{1}$ \\
$10{ }_{\mathrm{Ru}}, \mathrm{Ci}$ & $<2.60 \times 10^{0}$ & $<1.36 \times 10^{0}$ \\
$137 \mathrm{Cs}, \mathrm{Ci}$ & $1.62 \times 10^{1}$ & $1.58 \times 10^{1}$ \\
${ }^{60} \mathrm{Co}, \mathrm{Ci}$ & $<1.58 \times 10^{-1}$ & $<1.39 \times 10^{-1}$ \\
$\mathrm{U}, \mathrm{kg}$ & $<2.13 \times 10^{0}$ & $<2.13 \times 10^{0}$ \\
$\mathrm{Am}, \mathrm{g}$ & $2.64 \times 10^{-3}$ & $<2.64 \times 10^{-3}$
\end{tabular}

Evaluation of Scintillation Probe Data:

We1ls E28-18, E28-20 and E28-21 monitor the 216-B-62 process condensate crib (figures $A-1$ and A-140). Background activity in Well E28-18 was detected prior to disposal of condensate to the crib (figure A-141). In 1976 radioactive contaminants above background are detected in this well between 10.7 and 28.9 meters below the ground surface. Background activity is still detected in Wells E28-20 and E28-21 (figures A-142 and A-143).

The radionuclides disposed to the ground from the 216-B-62 crib are concentrated high in the sediment column near and beneath the headend of the crib. These data indicate breakthrough to the groundwater has not occurred at this site. 


\section{$\bullet$}

N43900

N43800

N43700

$\mathbf{N} 43600$

N43500

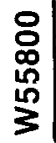

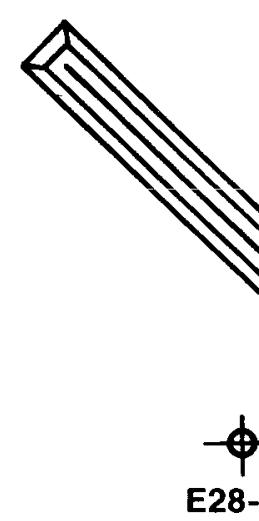

$\phi$

E28-21

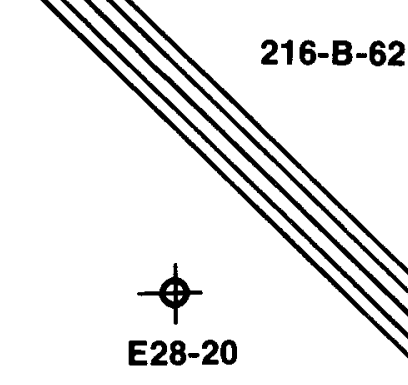

E28-20

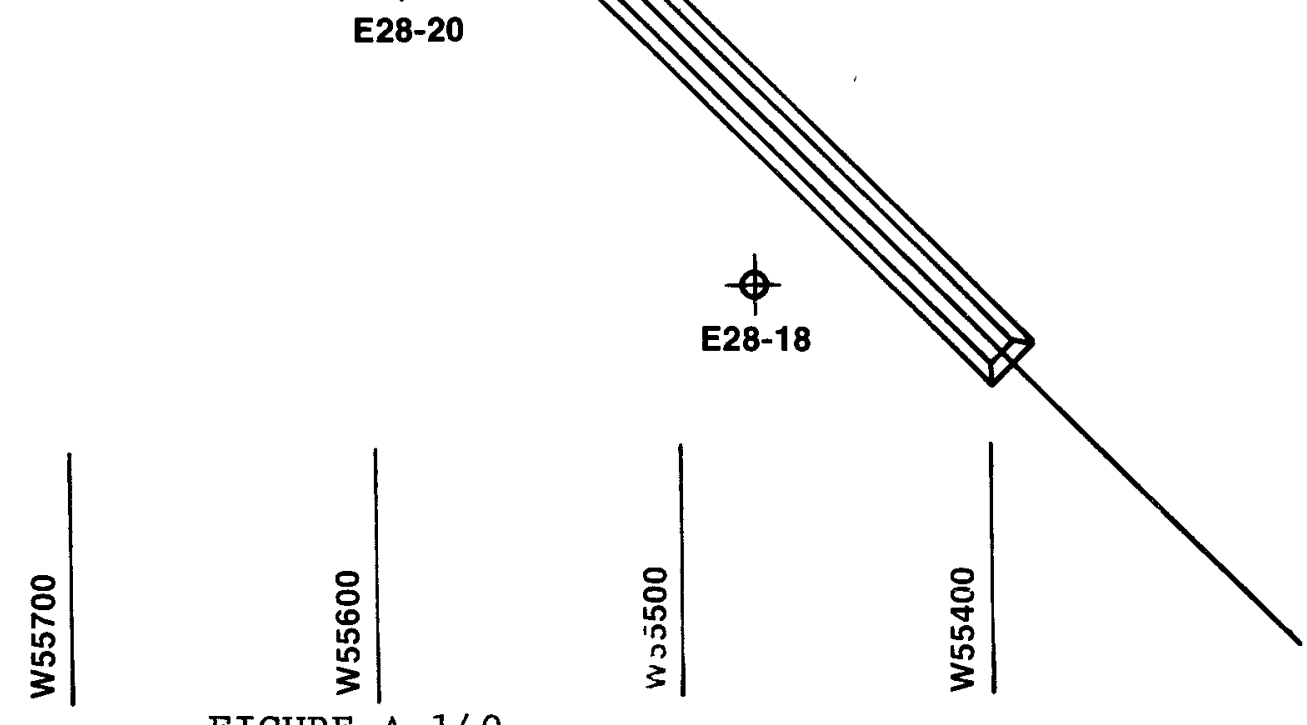




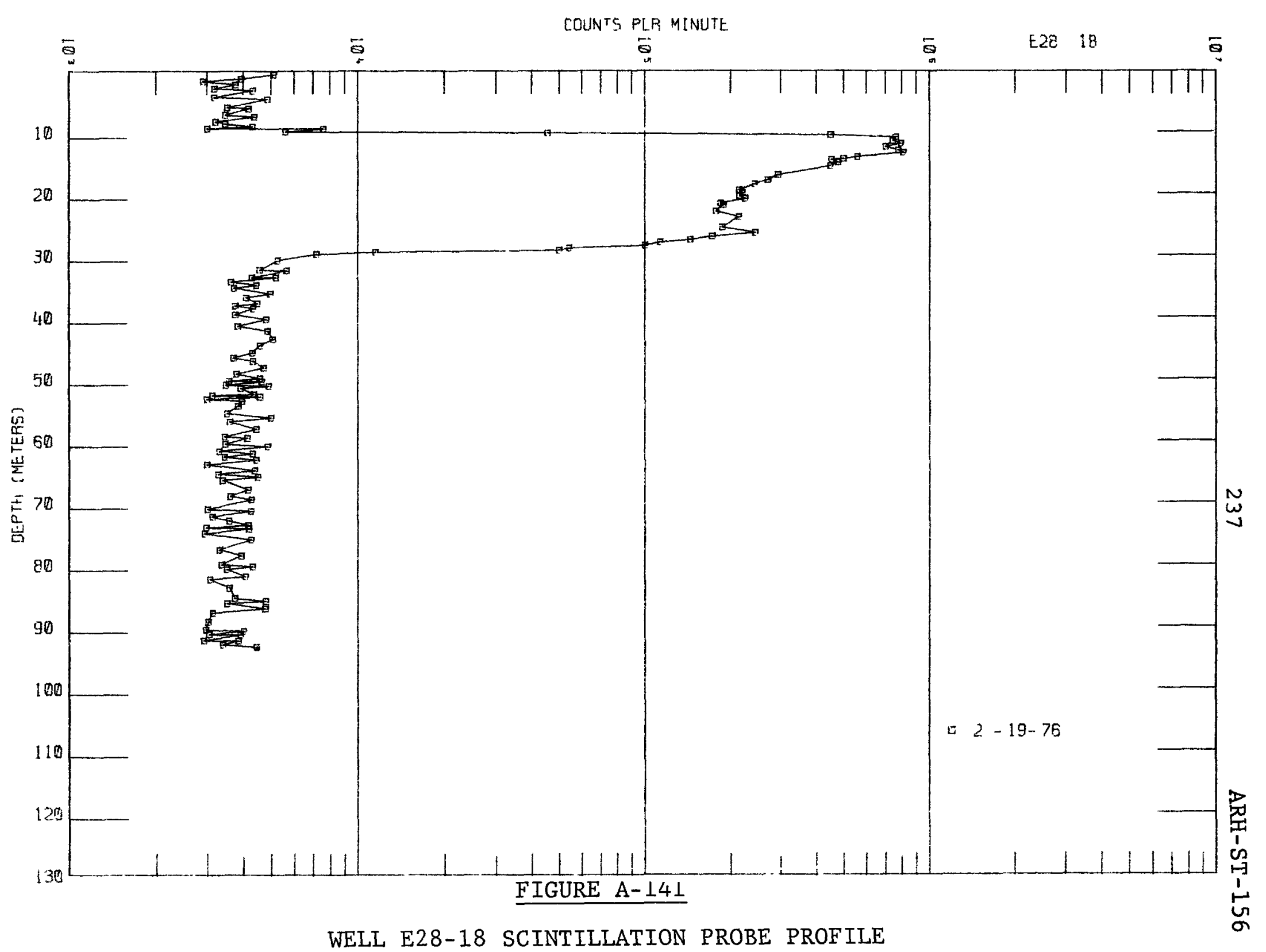


$0+$

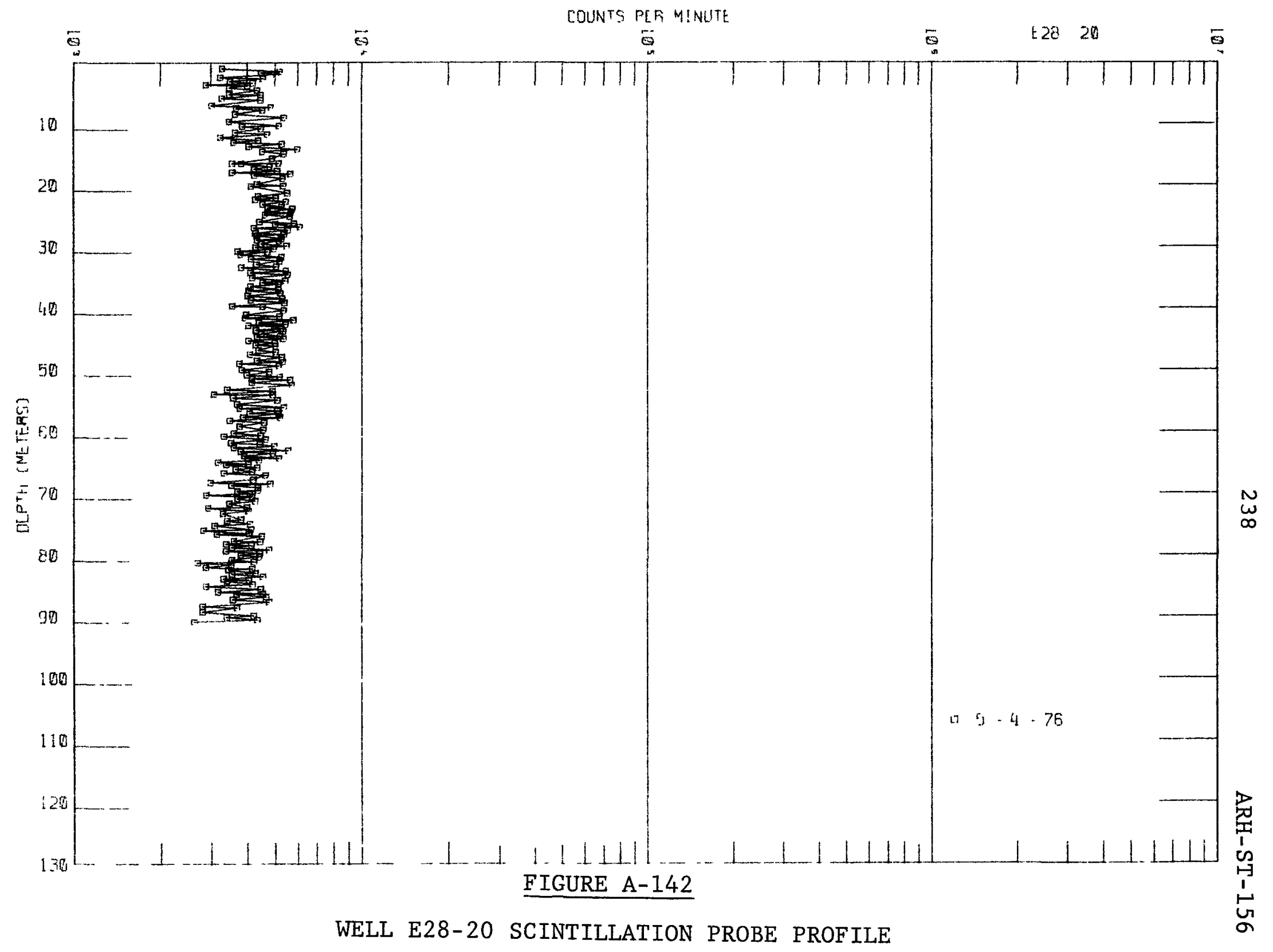




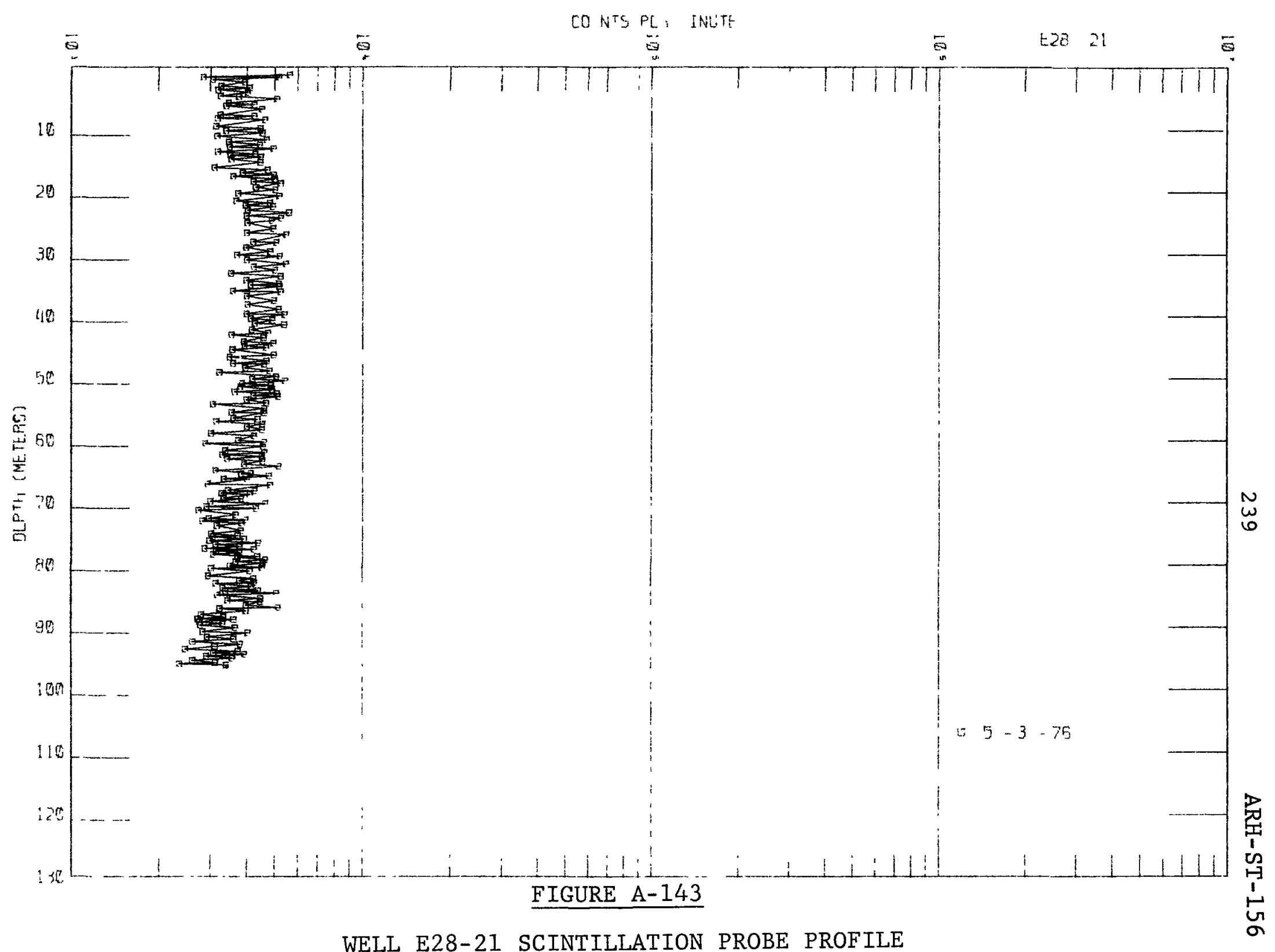


216-C-5 Specific Retention Crib

Description of Waste: High sait, cold run waste from 201-C semiworks.

Service Dates: 1955

Waste Volume: $3.79 \times 10^{4}$ iters

Waste Inventory:

Total

$\mathrm{Pu}, \mathrm{g}$

Beta, Ci

${ }^{90} \mathrm{Sr}, \mathrm{Ci}$

${ }^{106} \mathrm{Ru}, \mathrm{Ci}$

${ }^{137} \mathrm{Cs}, \mathrm{Ci}$

${ }^{60} \mathrm{Co}, \mathrm{Ci}$

$\mathrm{U}, \mathrm{kg}$
$1.00 \times 10^{0}$

$9.40 \times 10^{1}$

$1.00 \times 10^{1}$

$5.00 \times 10^{0}$

$<1.00 \times 10^{-1}$

$<1.00 \times 10^{-1}$

$5.44 \times 10^{1}$
Decayed Thru June 1976

$1.00 \times 10^{0}$

$1.21 \times 10^{1}$

$5.97 \times 10^{0}$

$2.56 \times 10^{-6}$

$<6.17 \times 10^{-2}$

$<6.28 \times 10^{-3}$

$5.44 \times 10^{1}$

Evaluation of Scintillation Probe Data:

We11 E24-8 monitors the 216-C-5 specific retention crib (figures A-1 and A-144). The radiation peak detected in Well E24-8 is due to the high level waste transfer lines that run from the 244-AR Vault to B Plant (figure A-145). The transfer line is located 3.2 meters from Well E24-8.

The waste volume and waste inventory indicate breakthrough to the groundwater has not occurred at this site. 

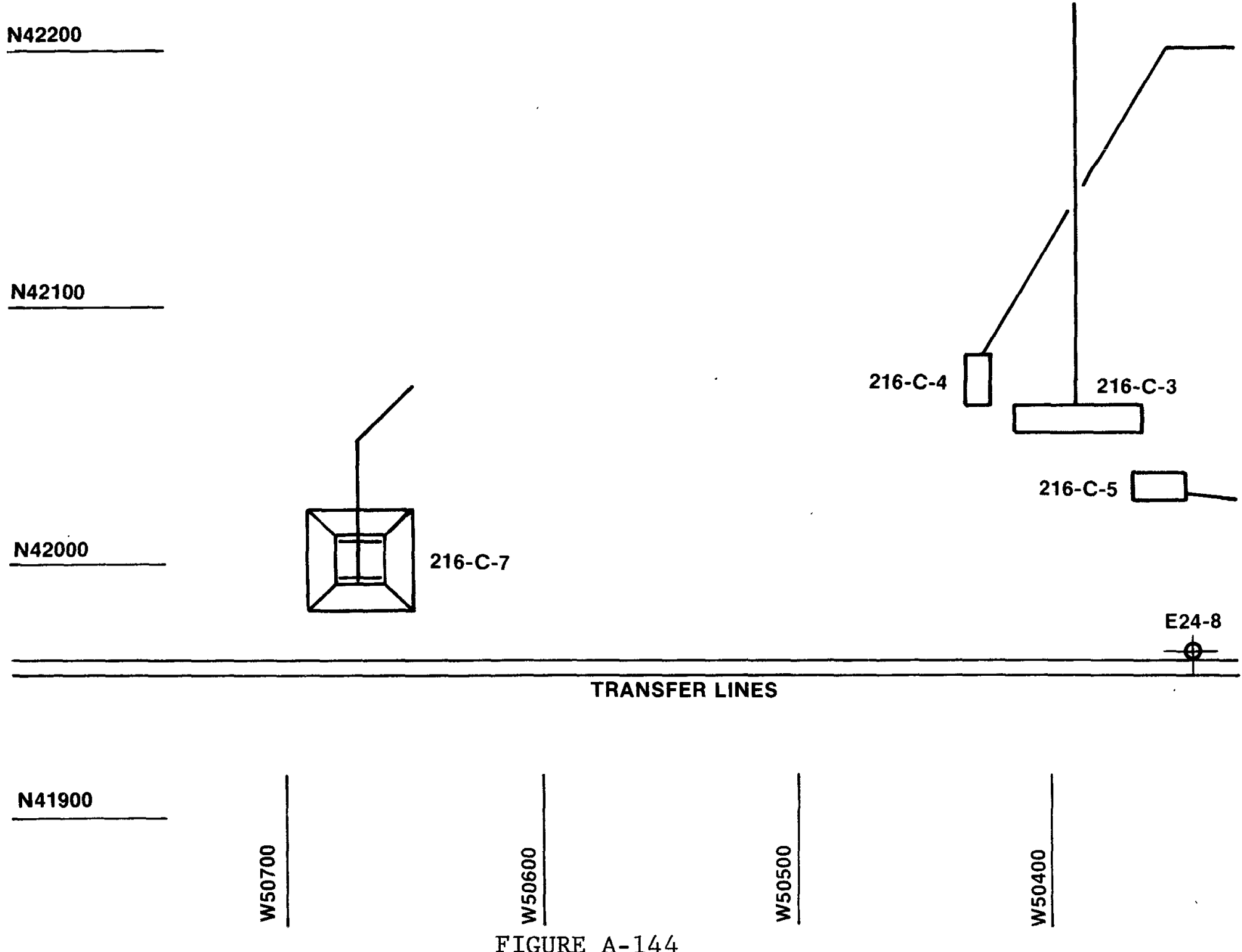

FIGURE A-144

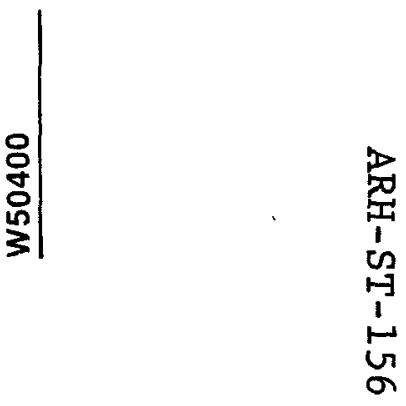

216-C-3, 216-C-4, 216-C-5 AND 216-C-7 CRIB PLOT PLANS 
$\infty 6$

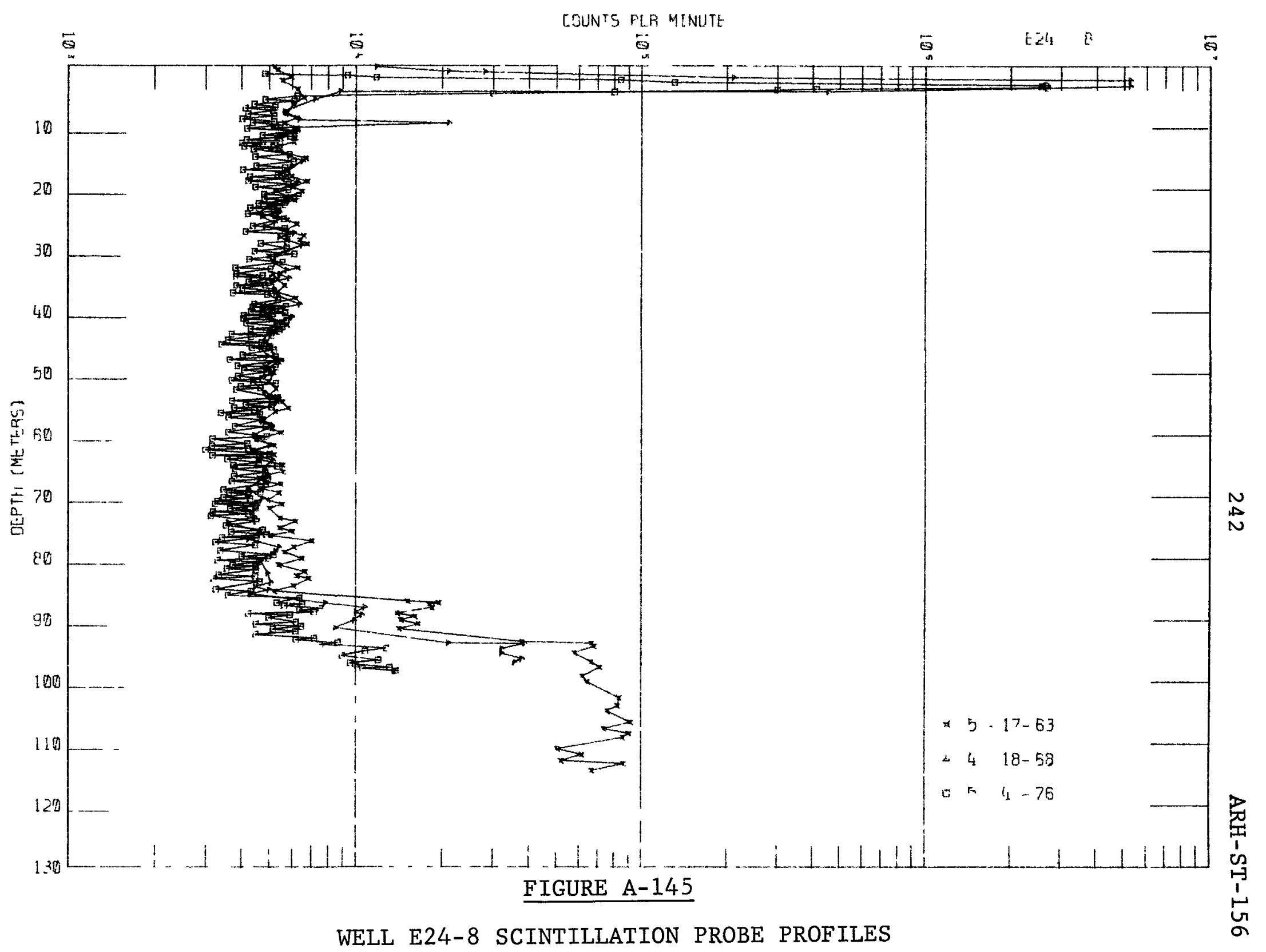




\section{$216-\mathrm{C}-10 \mathrm{Crib}$}

Description of Waste: Process condensate and liquid waste from 201-C semiworks.

Service Dates: 1964 to 1967

Waste Volume: $8.97 \times 10^{5}$ liters

Waste Inventory:

\begin{tabular}{|c|c|c|}
\hline & Total & Decayed Thru June 1976 \\
\hline $\mathrm{Pu}, \mathrm{g}$ & $<1.50 \times 10^{-1}$ & $<1.50 \times 10^{-1}$ \\
\hline Beta, Ci & $1.61 \times 10^{2}$ & $9.83 \times 10^{1}$ \\
\hline${ }^{90} \mathrm{Sr}, \mathrm{Ci}$ & $6.28 \times 10^{1}$ & $4.90 \times 10^{7}$ \\
\hline${ }^{106} \mathrm{Ru}, \mathrm{Ci}$ & $1.50 \times 10^{0}$ & $1.67 \times 10^{-3}$ \\
\hline${ }^{137} \mathrm{Cs}, \mathrm{Ci}$ & $<1.50 \times 10^{-1}$ & $<1.19 \times 10^{-1}$ \\
\hline${ }^{60} \mathrm{Co}, \mathrm{Ci}$ & $<1.50 \times 10^{-1}$ & $<3.95 \times 10^{-2}$ \\
\hline $\mathrm{U}, \mathrm{kg}$ & $<4.54 \times 10^{-2}$ & $<4.54 \times 10^{-2}$ \\
\hline
\end{tabular}

Evaluation of Scintillation Probe Profiles:

We11 E27-5 monitors the 216-C-10 crib (figures $A-1$ and A-146). Radioactive contaminants above background have not been detected (figure A-147). On the basis of these data breakthrough to the groundwater has not occurred at this site. 

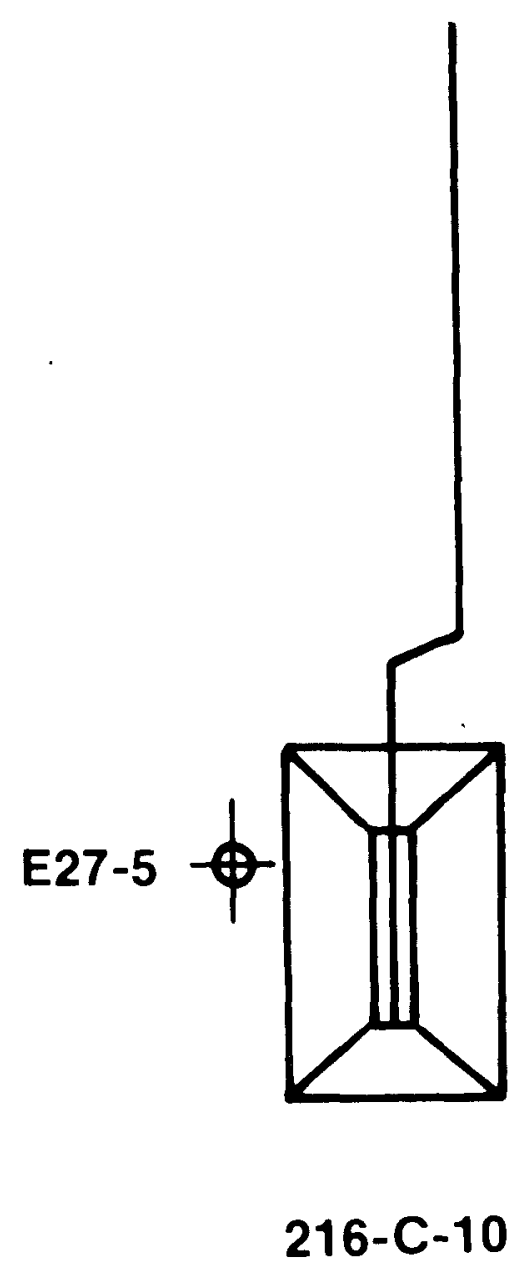

\section{W4.9800}
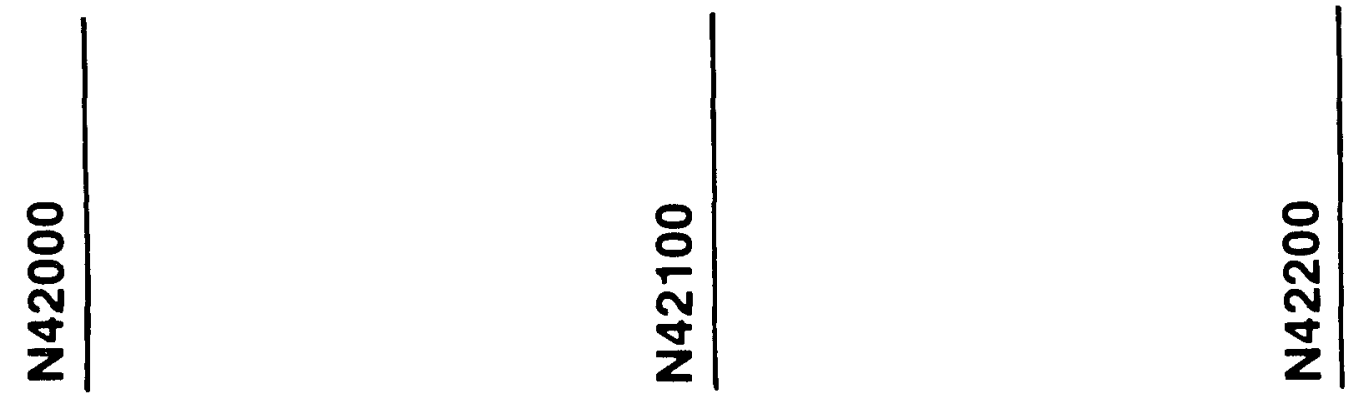

FIGURE A-146 


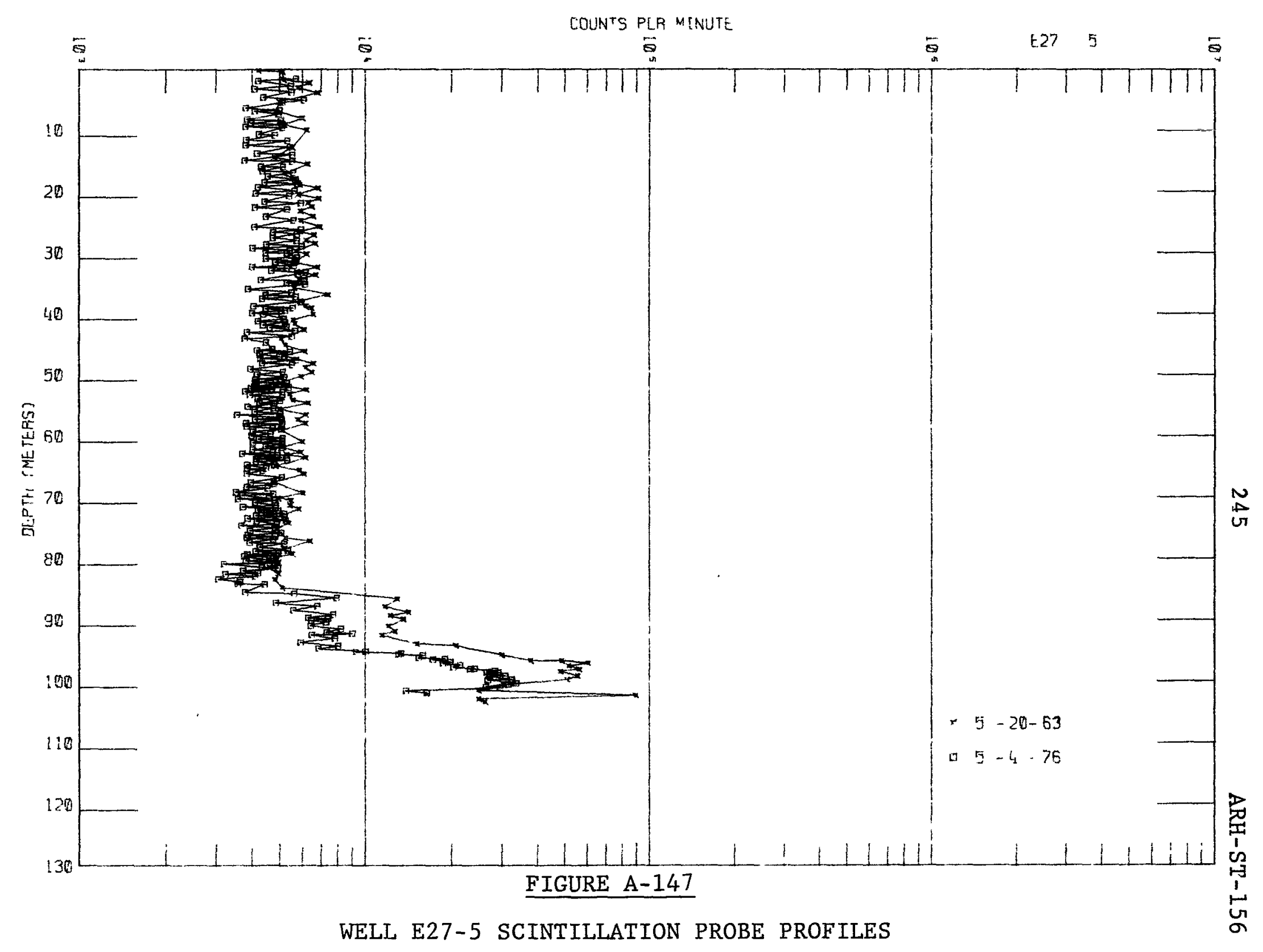

